UNIVERSIDADE DE SÃO PAULO

ESCOLA DE ENFERMAGEM

NAYARA GIRARDI BARALDI

\title{
PERÍODO PÓS-PARTO: PRÁTICAS DE CUIDADO ADOTADAS PELA PUÉRPERA
}

SÃO PAULO

2012 


\section{Período pós-parto: práticas de cuidado adotadas pela puérpera}

Dissertação apresentada ao Programa de PósGraduação em Enfermagem da Escola de Enfermagem da Universidade de São Paulo para obtenção do título de Mestre em Ciências.

Área de concentração: Cuidado em Saúde

Linha de pesquisa: $O$ cuidar nos processos da reprodução humana: modelos, agentes e práticas.

Orientadora: $\operatorname{Prof}^{a} \operatorname{Dr}^{a}$ Neide de Souza Praça

\section{São Paulo}

2012 


\section{Folha de aprovação}

Nome: Nayara Girardi Baraldi

Titulo: Período pós-parto: práticas de cuidado adotadas pela puérpera

Dissertação apresentada ao Programa de PósGraduação em Enfermagem da Escola de Enfermagem da Universidade de São Paulo para obtenção do título de Mestre em Ciências.

Aprovado em: ___

Banca Examinadora

Prof. Dr.

Instituição:

Julgamento:

Assinatura:

Prof. Dr.

Instituição:

Julgamento:

Assinatura:

Prof. Dr.

Instituição:

Julgamento:

Assinatura: 


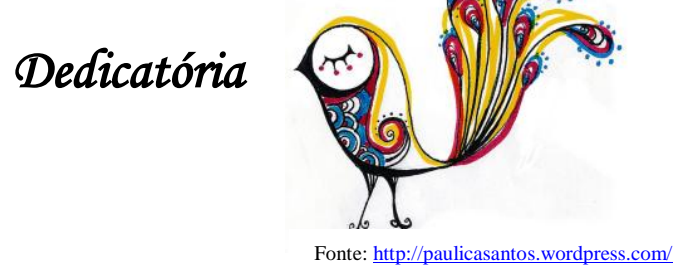

Ao curso de graduação em Obstetrícia pela Escola de Artes, Ciências e Humanidades da Universidade de São Paulo, que me proporcionou, por meio dos mestres e alunos, uma formação integralista e com visão humanista.

Às puérperas que compuseram esse estudo, pois sem elas de nada adiantaria meu esforço em construir esse sonho.

Aos meus pais Rosângela e João, e familiares, que sempre estiveram ao meu lado dando suporte e equilíbrio para a feitura deste trabalho.

A minha querida tia Lúcia Helena, pela disposição e luta incansável em ver a realização desse estudo.

Em especial, a minha avó Diva, pelos ensinamentos e dedicação ao longo de minha existência. E, também, aos meus avós Laura, Francisco e Jamil (in memoriam), pelo exemplo de vida que me deixou!

Ao meu namorado Sérgio, pelo carinho em me escutar e pela compreensão ao longo da elaboração deste projeto.

Por fim, à população rioclarense e a todos que acompanharam direta e indiretamente a construção e a realização deste sonho, que hoje, compõe uma realidade! 


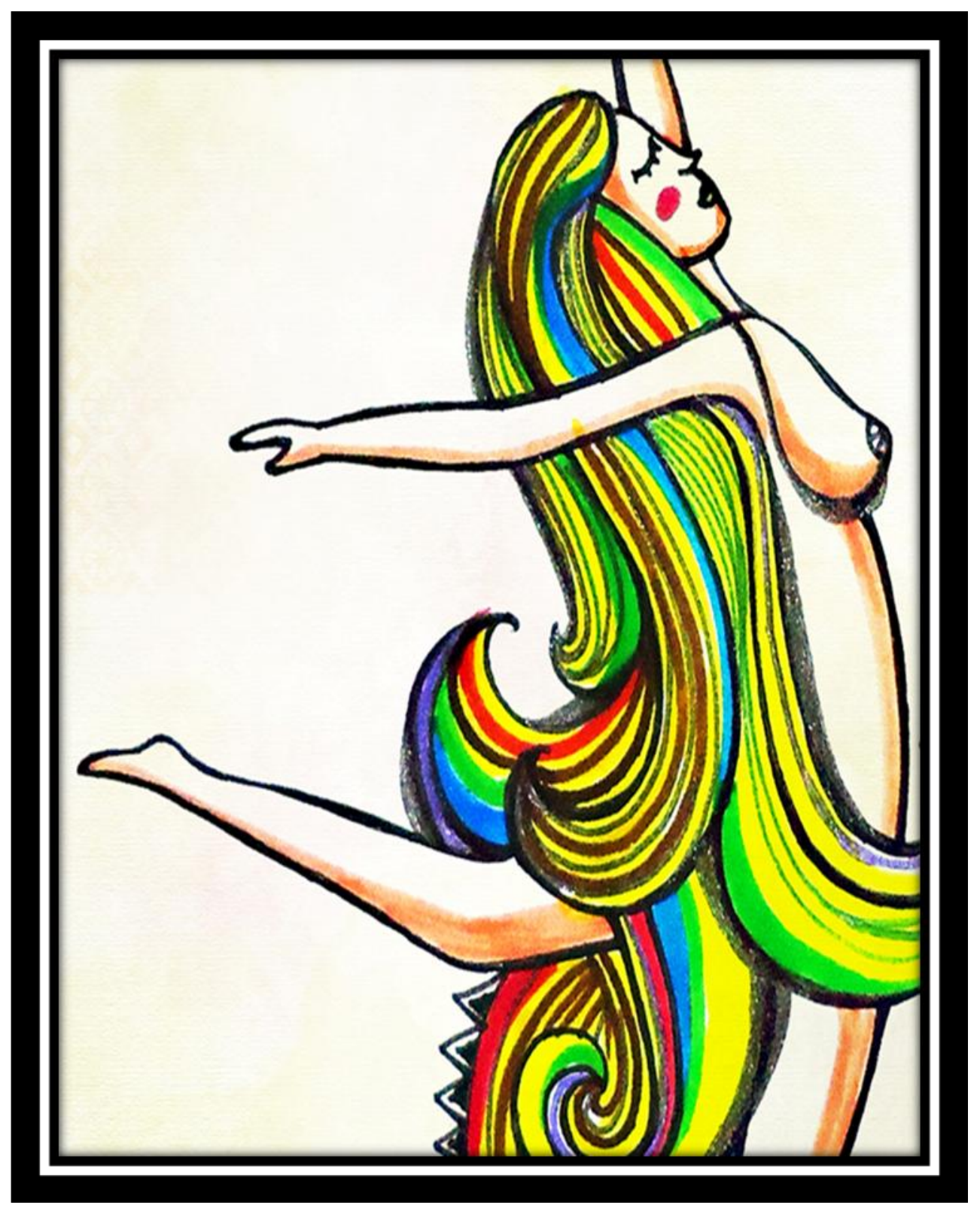

Fonte: http://paulicasantos.wordpress.com/

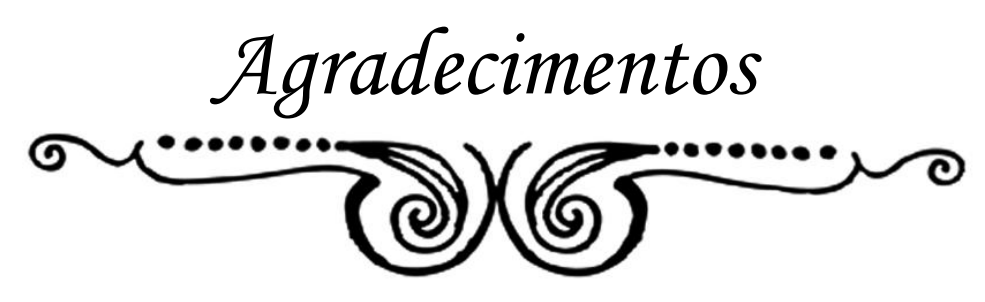


A Deus, pela sabedoria concedida a cada dia, pela Sua constante proteção e pelo dom do discernimento nos momentos de espera.

À Fundação de Amparo à Pesquisa do Estado de São Paulo (FAPESP), por concederme a bolsa de mestrado, que valorizou e auxiliou a realização deste projeto.

À Coordenação de Aperfeiçoamento de Pessoal do Nível Superior (CAPES), que me concedeu auxílio financeiro de caráter emergencial e possibilitou a feitura deste estudo.

À minha orientadora, Prof ${ }^{a} \operatorname{Dr}^{a}$ Neide de Souza Praça, pela exímia dedicação, pelo respeito e pela companhia no delineamento deste projeto, desde seu alvorecer até sua síntese final.

Às professoras Dr ${ }^{\mathrm{a}}$ Isília Aparecida Silva e $\operatorname{Dr}^{\mathrm{a}}$ Roselena Bazilli Bergamasco, pela disponibilidade, pelo carinho e pelas valorosas contribuições no Exame de Qualificação.

À Prof ${ }^{a}$ Dr $^{a}$ Célia Regina Maganha e Melo, pelo carinho que me acolheu e me orientou nas atividades do PAE, colaborando para meu crescimento profissional.

Às funcionárias do Departamento de Pós-Graduação da Escola de Enfermagem da Universidade de São Paulo, no papel da Dayse, que sempre se apresentaram disponíveis em ajudar-me frente às necessidades da vida acadêmica.

Às puérperas que participaram deste estudo, pelo respeito com qual me concederam relatar um período de suas vidas, o que viabilizou diretamente a construção deste projeto.

À equipe da Unidade Básica de Saúde, que acolheu o projeto, pela ajuda, pelo respeito e pela companhia, os quais culminaram nos laços de amizade.

Ao Secretário da Saúde e aos dirigentes do setor da Atenção Básica da Fundação Municipal de Saúde de Rio Claro, pela oportunidade em desenvolver esse estudo no município.

Ao Jorge Alves de Lima, professor de português, que ficou responsável pela revisão final deste projeto.

Ao Fábio Montenegro Carnevale, que colaborou na transcrição e na correção do resumo na língua inglesa.

À Larissa, minha irmã, pela colaboração nas transcrições.

À minha família, ao meu namorado e aos meus amigos, que estiveram sempre ao meu lado, nas alegrias e nas dificuldades.

E a todos que torceram pela realização deste estudo.

Muito obrigada! 


\section{Epigrafe}
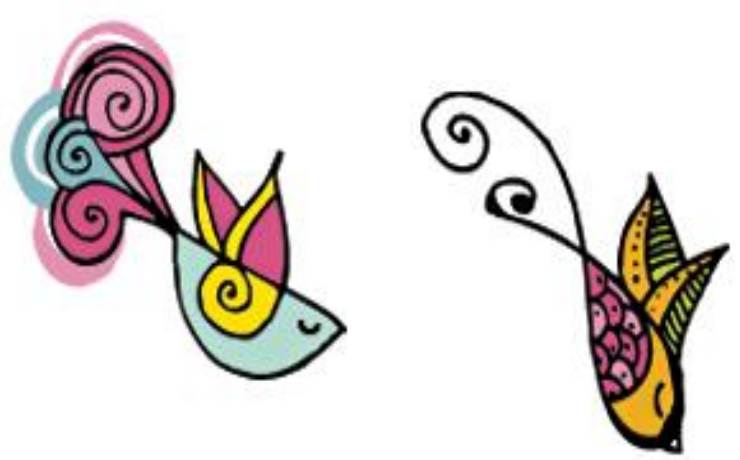

HOUVE um tempo em que a minha janela se abria para um chalé.

HOUVE um tempo em que a minha janela dava para um canal.

HOUVE um tempo em que minha janela se abria para um terreiro, onde uma vasta mangueira alargava sua copa redonda.

HOUVE um tempo em que a minha janela se abria sobre uma cidade que parecia feita de giz. MAS, quando falo dessas pequenas felicidades, que estão diante de cada janela, uns dizem que essas coisas não existem, outros que só existem diante das minhas janelas e outros, finalmente, que é preciso aprender a olhar, para poder vê-las assim.

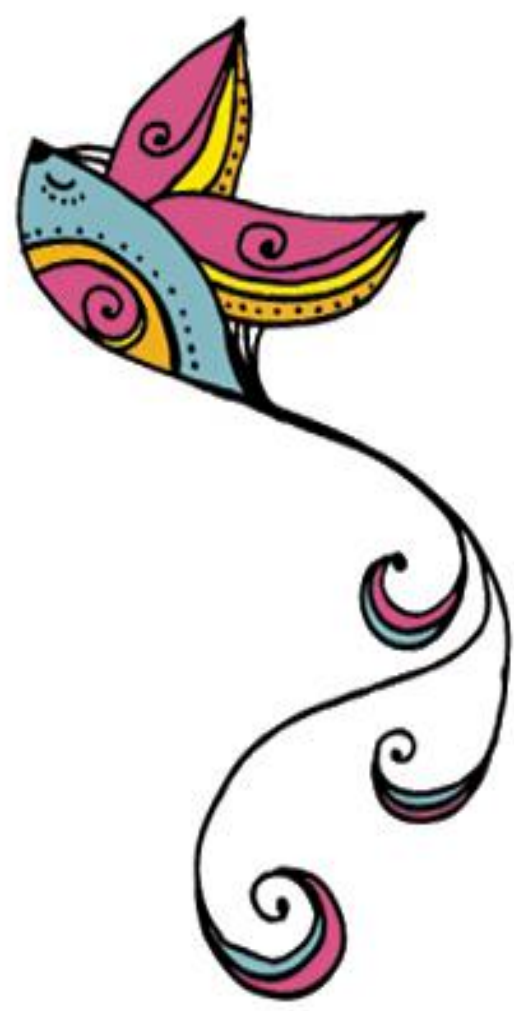

(Adaptação da crônica "A arte de ser feliz”, de Cecília Meireles)
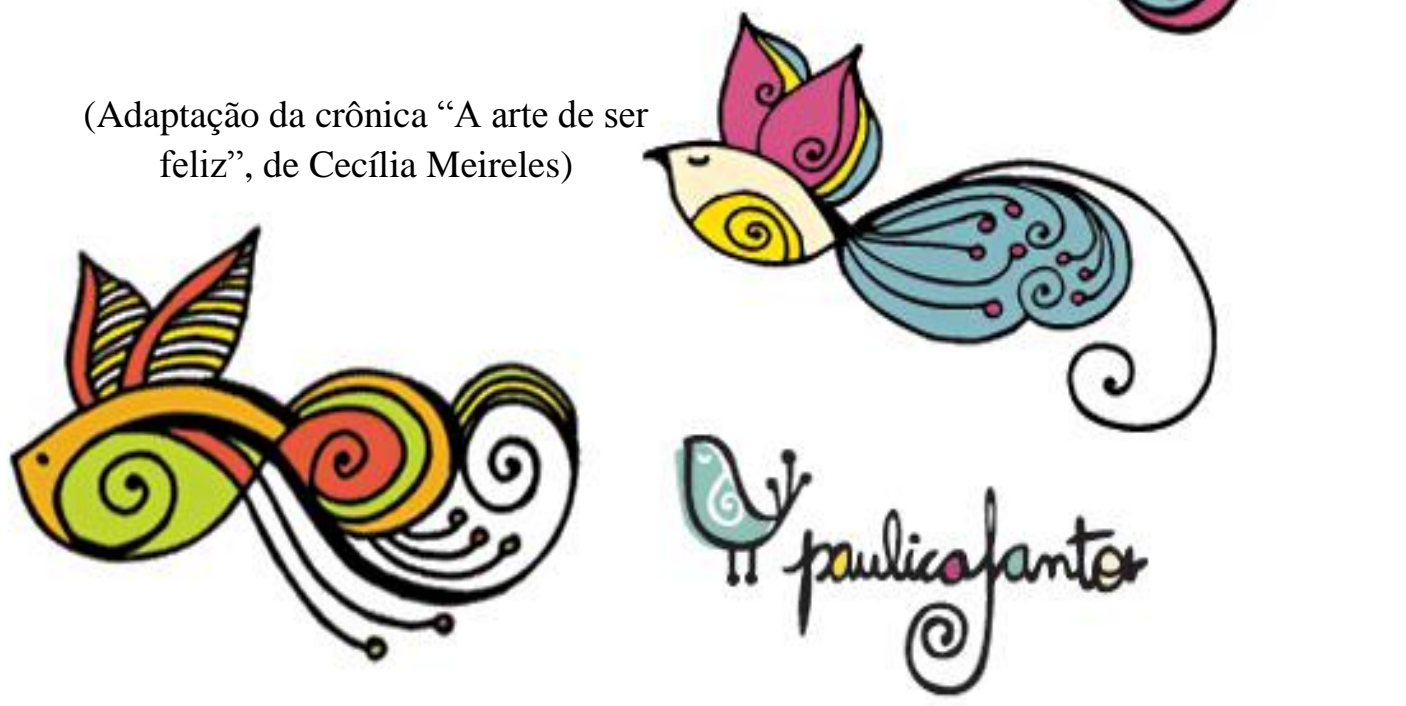

Fonte: http://paulicasantos.wordpress.com/ 
Baraldi NG. Período pós-parto: práticas de cuidado adotadas pela puérpera [dissertação]. São Paulo: Escola de Enfermagem, Universidade de São Paulo; 2012.

\section{RESUMO}

O puerpério é considerado uma fase de modificações biossocioculturais que, muitas vezes, não são compreendidas pela mulher, o que exige maior atenção dos profissionais, dos familiares e das redes de contato envolvidos em seu cuidado. A literatura e a prática profissional mostram que as crenças sobre o cuidado da puérpera têm relevância em seu cotidiano e, muitas vezes, se sobrepõem às orientações recebidas na instituição de saúde. Diante desta situação, este estudo teve como objetivo: explorar as práticas de cuidado adotadas no pós-parto pela mulher usuária de uma Unidade Básica de Saúde da cidade de Rio Claro, SP. Trata-se de estudo qualitativo, que teve como referencial teórico o Modelo de Competência Cultural de Purnell e cujos dados foram tratados pelo Discurso do Sujeito Coletivo (DSC). A pesquisa foi aprovada por Comitê de Ética em Pesquisa e atendeu à Resolução 196/96. Os dados foram coletados em 2011, por meio de entrevistas realizadas com 20 puérperas entre o $30^{\circ}$ e $45^{\circ}$ dias de pós-parto. Identificou-se a condição sociodemográfica e familiar das entrevistadas, além de sua vivência no puerpério. Os dados mostraram que as puérperas eram jovens, apresentavam baixo índice de tabagismo, etilismo e drogadição, com renda média em torno de 3 salários mínimos. Os relatos obtidos originaram 21 DSC, cujos conteúdos mostraram a influência de crenças sobre as práticas de cuidado no puerpério; crenças que foram transmitidas intergerações pelos cuidadores de sua rede familiar e cultural. Os profissionais de saúde se fizeram presentes por meio de orientações de práticas, com enfoque no biológico, oferecidas de maneira verticalizada e, por vezes, fragmentada e divergente, o que demonstrou sua dificuldade em acompanhar as influências culturais envolvidas no processo. Por conta disso, as práticas de cuidado no puerpério sofreram maior influência das crenças e dos padrões da cultura da mulher, como também das informações obtidas na internet, que preencheram lacunas e apontaram caminhos para a mulher seguir com maior segurança nesta fase do ciclo gravídicopuerperal. Diante dos achados, propõem-se o estabelecimento de estratégias para incorporação da bagagem cultural da mulher à assistência prestada pelo profissional de saúde, de modo a prover o cuidado culturalmente competente; a programação de grupos voltados à educação em saúde, focados na vivência do puerpério, para a mulher e sua rede de contato; a implementação da Estratégia Saúde da Família; e a inclusão do egresso de curso de Obstetrícia nos programas de saúde dos municípios, para agregar este novo profissional no cuidado da mulher e de seu recém-nascido.

Palavras-chave: Cuidado pós-natal, Cultura, Saúde da mulher, Pesquisa qualitativa, Competência Cultural. 
Baraldi NG. Postpartum period: care practices adopted by the woman in the puerperium [thesis]. São Paulo (SP), Brasil: Escola de Enfermagem, Universidade de São Paulo; 2006.

\begin{abstract}
Puerperium is considered a phase with biological, social and cultural changes often not correctly understood by women, the main reason why requires special attention from professionals, and caregivers networks involved on the care. Literature and professional practice shows that beliefs about postpartum care has a strong relevance in a woman's routine and often overlaps guidance received at the health institutions. From this perspective, this study had as objective to explore practices adopted in postpartum by women served in the Basic Health Unit in a city of Rio Claro state of São Paulo (Brazil). This is a qualitative study and followed Purnell Cultural Competence Model as a theoretical approach and whose data was treated by the Collective Subject Speech (CSS). The data was approved by Ethics in Research Committee and complied with Resolution 196/96. The data was collected in 2011 through interviews with 20 women in the puerperium between 30 and 45 days of postpartum. We identified social and demographic conditions from each interviewed as well as from her family, besides their experiences at the puerperal period. The data showed that women in the puerperium were young, had low smoking rates, alcoholism or drugs addictions, and on average had an income that was equivalent to 3 minimum salaries. The reports had originated $21 \mathrm{CSS}$, and the contents showed the stronger beliefs influence on postpartum care practices; beliefs that were passed by intergenerational family and cultural caregivers. Health professionals demonstrated their presence through guidelines with practices with a biological focus and offered in a vertical manner, and sometimes divergent and fragmented, which demonstrated difficulty in following the cultural influences involved in the process. For this reason, puerperal care practices had suffered greatly due to the influence of beliefs and cultural woman patterns, as well as information obtained from the Internet. The Internet filled gaps and provided greater security methods to follow at pregnancy stage, childbirth as well as at puerperium. Upon reviewing the results, it is suggested that the following take place to incorporate the cultures of women to the experiences of the health care professionals to provide a culturally competent care; programming groups on health education focused on the puerperium experience for women and her caregivers; the implementation of Family Health Program, and the inclusion of Midwifery in the health programs to allow this new professional to take care the woman and her newborn.
\end{abstract}

Key words: Postnatal care, Culture, Women's health, Qualitative research, Cultural Competency. 


\section{Lista de ilustrações}

Figura 1 - Modelo de Competência Cultural de Purnell representado na forma de círculo com as dimensões globais, e os 12 domínios, considerados microaspectos

Figura 2 - Organograma das etapas para coleta de dados 43

Quadro 1- O passo a passo da construção do DSC

Quadro 2- Relação dos DSC e sua inserção nos domínios do Modelo de Competência Cultural de Purnell 


\section{Lista de abreviaturas e siglas}

CAPES - Coordenação de Aperfeiçoamento de Pessoal de Nível Superior CE - Ceará

CEP - Comitê de Ética em Pesquisa

CSS - Collective Subject Speech

EM - Ensino médio

ES - Ensino superior

$\mathrm{ES}_{1}-$ Espírito Santo

EUA - Estados Unidos da América

FAPESP - Fundação de Amparo à Pesquisa do Estado de São Paulo

GO - Goiás

IBGE - Instituto Brasileiro de Geografia e Estatística

IC - Ideia central

MCC - Modelo de Competência Cultural

MEC - Ministério da educação

$\mathrm{N}^{\circ}$ - Número

OMS - Organização Mundial da Saúde

PAE - Programa Aperfeiçoamento de Ensino

PC - Parto cesárea

PHPN - Programa de Humanização do Parto e do Nascimento

PN - Parto normal

$\mathrm{PN}_{1}-$ Pré-natal

PSF - Programa Saúde da Família

PR - Paraná

Prof $^{\mathrm{a}}$ Dr $^{\mathrm{a}}$ - Professora Doutora

SM - Salário-mínimo

SP - São Paulo

RS - Rio Grande do Sul

TCLE - Termo de Consentimento Livre e Esclarecido

UBS - Unidade Básica de Saúde

USF - Unidade Saúde da Família 
USP - Universidade de São Paulo 


\section{Lista de símbolos}

® - Marca registrada

*** - Pausa (descanso) 


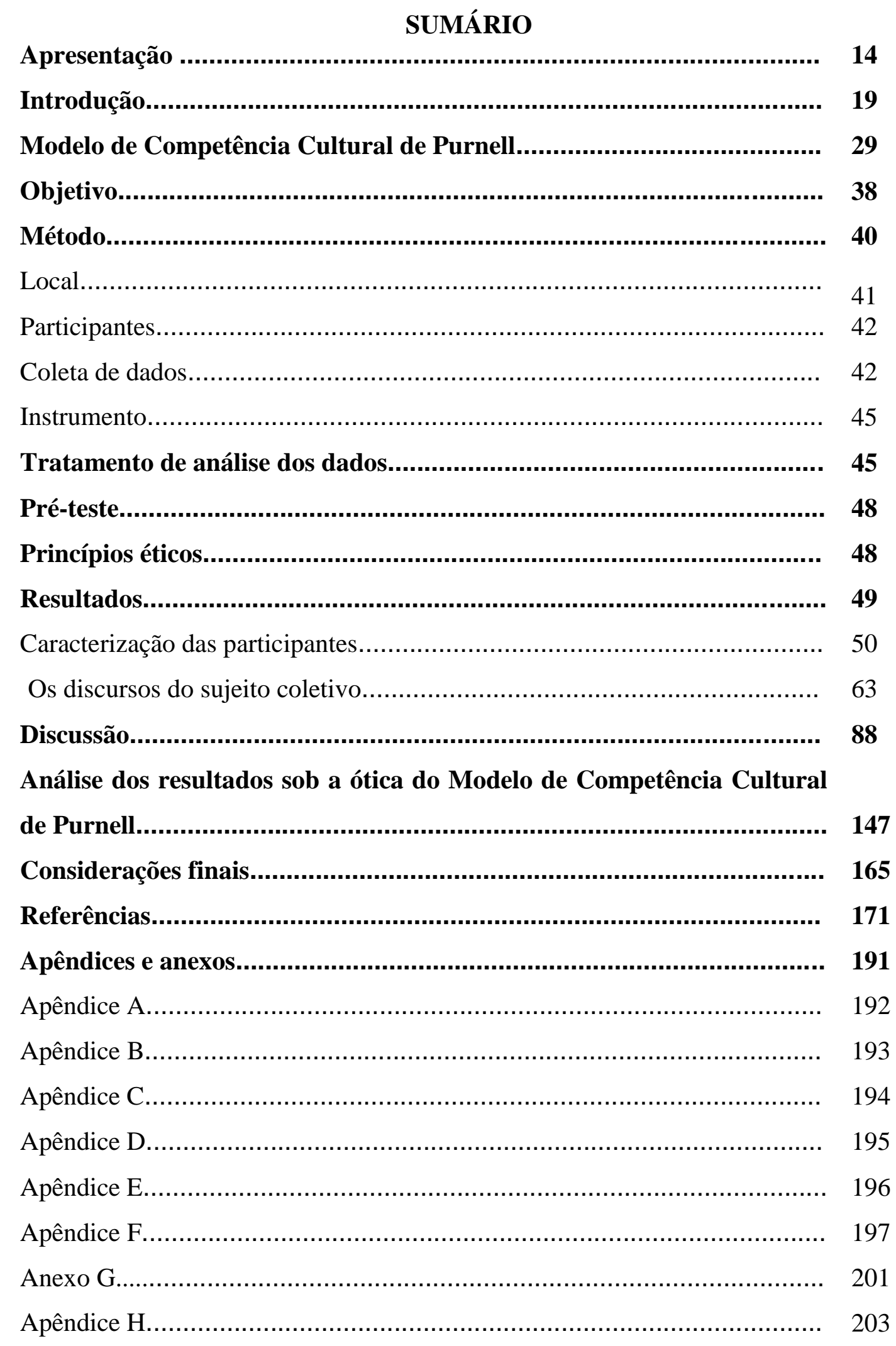




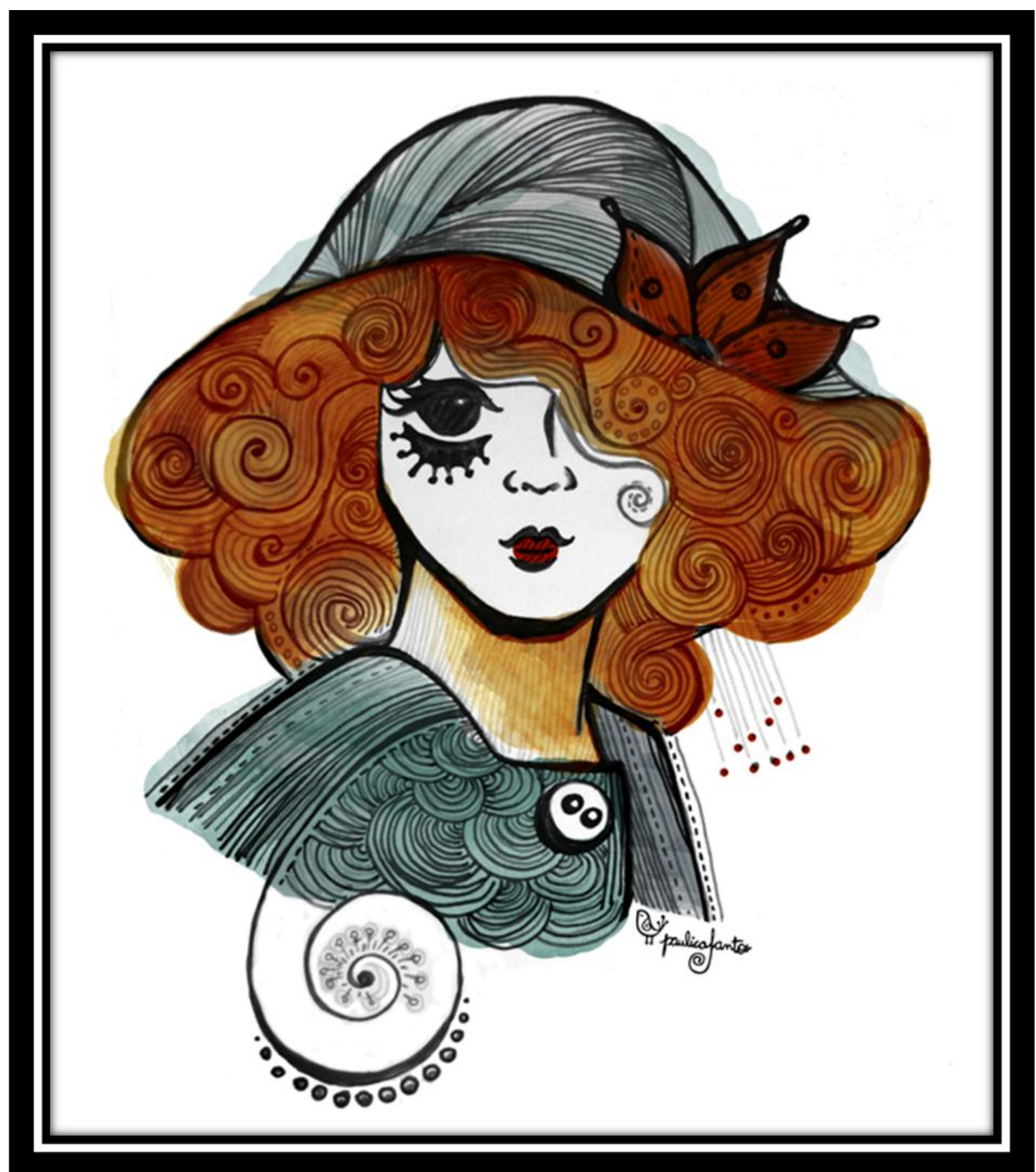

Fonte: http://paulicasantos.wordpress.com/

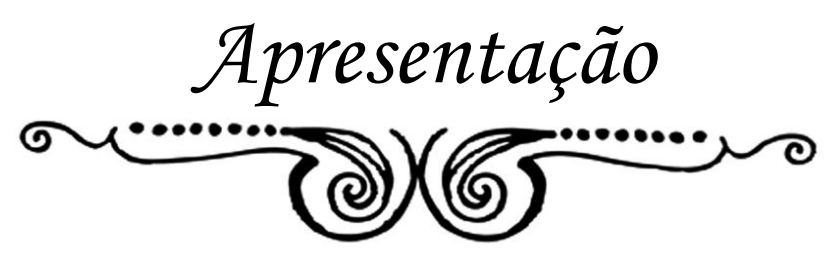


A revisão de literatura sobre o pós-parto mostrou que trata-se de um período marcado pela vulnerabilidade da nova mãe, devido às mudanças socioculturais e fisiológicas; no entanto, as intercorrências e as patologias são os temas que ganham destaque no período. Neste aspecto, também a prática profissional mostra que as crenças disseminadas em seu contexto sobre o cuidado da puérpera têm relevância em seu cotidiano e, muitas vezes, se sobrepõem às orientações recebidas na instituição de saúde.

Minha prática profissional e pessoal mostra que o avanço científico, no campo da saúde, e dos meios de comunicação parecem não exercer influência sobre as práticas de cuidado realizadas pela mulher durante o puerpério, o que motivou o desenho deste estudo de abordagem qualitativa.

Meu contato com os cuidados no pós-parto foram anteriores a minha formação em Obstetrícia, pois estão presentes em minha vida desde a infância, uma vez que, em minha família, os parentes de gerações mais antigas, que já vivenciaram as transformações do ciclo gravídico-puerperal, ajudam as novas gerações no cuidado no pós-parto.

No nascimento de meu primo mais novo, em 2007, recordo-me de minha avó materna falando sobre carne de porco servida na maternidade. Minha tia comeu e minha avó a repreendeu, dizendo-lhe que poderia sofrer alguma intercorrência na cicatrização da incisão cirúrgica. Além disso, minha tia relatava que tivera os cabelos lavados sem seu consentimento pela equipe de enfermagem do hospital, que também a colocou para tomar banho. Dessa forma, ela se submeteu ao banho e à lavagem dos cabelos, mesmo sem o desejar, o que lhe causou medo que algo de ruim pudesse lhe acontecer.

Além do relato anterior, desde quando iniciei minha graduação em Obstetrícia pela Universidade de São Paulo, a maior parte dos docentes ensinava que deveríamos cuidar e respeitar as diferenças socioculturais das clientes, pois, ir contra tais paradigmas familiares e culturais, sem embasamento teórico e prático, geraria uma agressão ao indivíduo que era atendido. Além disso, por já ter tido a experiência em minha realidade familiar, na qual os cuidados cultural e socialmente perpassados foram deixados de lado pela equipe de enfermagem, decidi me dedicar a compreender o motivo da ocorrência destas situações. 
Ainda como estudante de graduação em Obstetrícia, recordo-me dos estágios em Assistência à Saúde da Mulher na Família e Sociedade, que praticava em uma Unidade Básica de Saúde, na Zona Leste do município de São Paulo. Nesse serviço, havia sido implantada a Estratégia Saúde da Família que, junto à Rede Mãe Paulistana, visava oferecer consultas de pré-natal, além de prestar outros cuidados às mulheres grávidas e puérperas. Também era promovida, por estes programas, uma visita puerperal, realizada por enfermeiras e por agentes comunitários, aos 7 dias de pós-parto, para avaliação e orientação de mães e recém-nascidos.

Nos primeiros dias de estágio, ao realizar, com uma colega de curso e uma agente comunitária, uma consulta puerperal, nos deparamos com uma família na qual a avó materna da puérpera não queria permitir nossa entrada na residência, pois sua neta estava com 7 dias de pós-parto e, nesta ocasião, não poderia receber nenhuma visita, pois poderia desencadear o "mal dos sete dias". Frente ao caso, dissemos que retornaríamos no outro dia, mas a mãe da puérpera, intervindo, permitiu nossa entrada e nos pediu para que orientássemos sua filha, pois havia uma semana que ela permanecia apenas deitada, enquanto o banho era feito na cama com pano e água aquecida, pois a avó não permitia que a neta andasse pela casa, para não correr o risco de sofrer uma "recaída" ou de os pontos "estourarem". Ao me encontrar com a puérpera, que era adolescente, percebi que estava confusa, com medo e apática pelo tratamento que estava recebendo da avó. Frente a isso, como a avó se recusou a nos receber, nós, como profissionais de saúde, fizemos orientações e explicamos as dúvidas sobre o cuidado no pós-parto para a puérpera e sua mãe; além disso, salientamos o que poderia ajudá-la em sua higiene, alimentação e repouso, mas sem quebrar os paradigmas daquela família.

O tempo foi passando e, a cada consulta puerperal naquele bairro periférico, eu encontrava crenças diferentes, mas persistentes. Até então, eu acreditava que tais crenças e valores fossem mais persistentes em regiões do interior do Estado, de onde eu vinha, porém a vivência da prática clínica me fez perceber que essa premissa não era válida. Outra situação com a qual me deparava era que, mesmo a mulher recebendo orientações durante o pré-natal e na maternidade, ao se deparar com os ensinamentos advindos dos familiares e do meio cultural, acabava dando preferência a esses e, quando não o fizesse, se sentia culpada e com medo por não os seguir. 
Depois de formada, enquanto aluna da pós-graduação, fui estagiária do Programa de Aperfeiçoamento do Ensino, quando verifiquei que muitas mulheresmães, que eu acompanhava durante o ciclo gravídico-puerperal, junto aos grupos de alunos, tinham crenças e valores relacionados à higienização e ao uso de banho de assento para melhor cicatrização da episiorrafia, assim como cuidados com a higiene da cabeça devido à inversão dos humores. Também apresentavam cuidados próprios com a alimentação no puerpério, devido à amamentação, além da sutura. Ainda salientavam a necessidade do benzimento e do "resguardo" para não sofrerem "recaída" e nunca mais se curarem. O que mais me chamava a atenção era que as crenças e os valores persistiam e grande parte dos profissionais de saúde, além de não serem favoráveis, eram taxativos em quebrá-los e em repreender as puérperas por tais práticas, não considerando seu ser biopsicossociocultural.

Frente a isso, decidi realizar uma revisão de literatura, para avaliar os trabalhos publicados com esta temática, buscando solucionar os meus questionamentos sobre essa interface dos cuidados culturais e oriundos da biomedicina. Deparei-me com um número baixo de pesquisas relatando esse contexto: na verdade, existiam trabalhos mostrando a necessidade de mudanças da equipe profissional em relação aos cuidados biomédicos, os quais deveriam levar em consideração a parte psicológica, social e cultural do indivíduo, mas, ao analisar o campo do ciclo gravídico-puerperal, verifiquei que os estudos eram escassos e relativamente antigos quando relacionados à fase do puerpério.

Por isso, ao refletir sobre o assunto, me dei conta que, tanto na literatura como na prática profissional, há grande destaque e incentivo às consultas de prénatal, elevada importância com o momento do parto e do puerpério imediato, porém, após a alta da maternidade, o número de consultas pós-natal é extremamente reduzido e ocorre em dois momentos: aproximadamente na primeira semana após o nascimento e após os quarenta dias de pós-parto. Na sequência, o bebê era acompanhado pela puericultura e a puérpera era "esquecida".

Do exposto, percebi a necessidade da compreensão biopsicossociocultural da clientela por parte dos profissionais e constatei a carência de estudos envolvendo um período carregado de transformações biológicas, psicológicas e sociais; busquei, então, realizar este estudo, visando não apenas compreender a importância de um 
atendimento qualificado e digno, que assegure à puérpera o direito de escolha frente ao cuidado no puerpério, mas também evidenciar que mesmo após alguns anos buscando a humanização na saúde, ainda como profissionais, falhamos ao querer impor nossa excelência de cuidado, esquecendo da realidade e da cultura de nossas mulheres.

Sendo assim, por meio deste estudo e frente às histórias por mim vivenciadas com familiares e clientes, espero incentivar uma mudança de paradigmas e de sensibilização nas práticas ofertadas pelos profissionais de saúde, frente aos cuidados de suas clientes - que vão além de um corpo biológico. Busco também, contribuir com os serviços de atenção básica voltados para a saúde da mulher e para a maternidade, apontando caminhos para a assistência biopsicossociocultural da puérpera. 


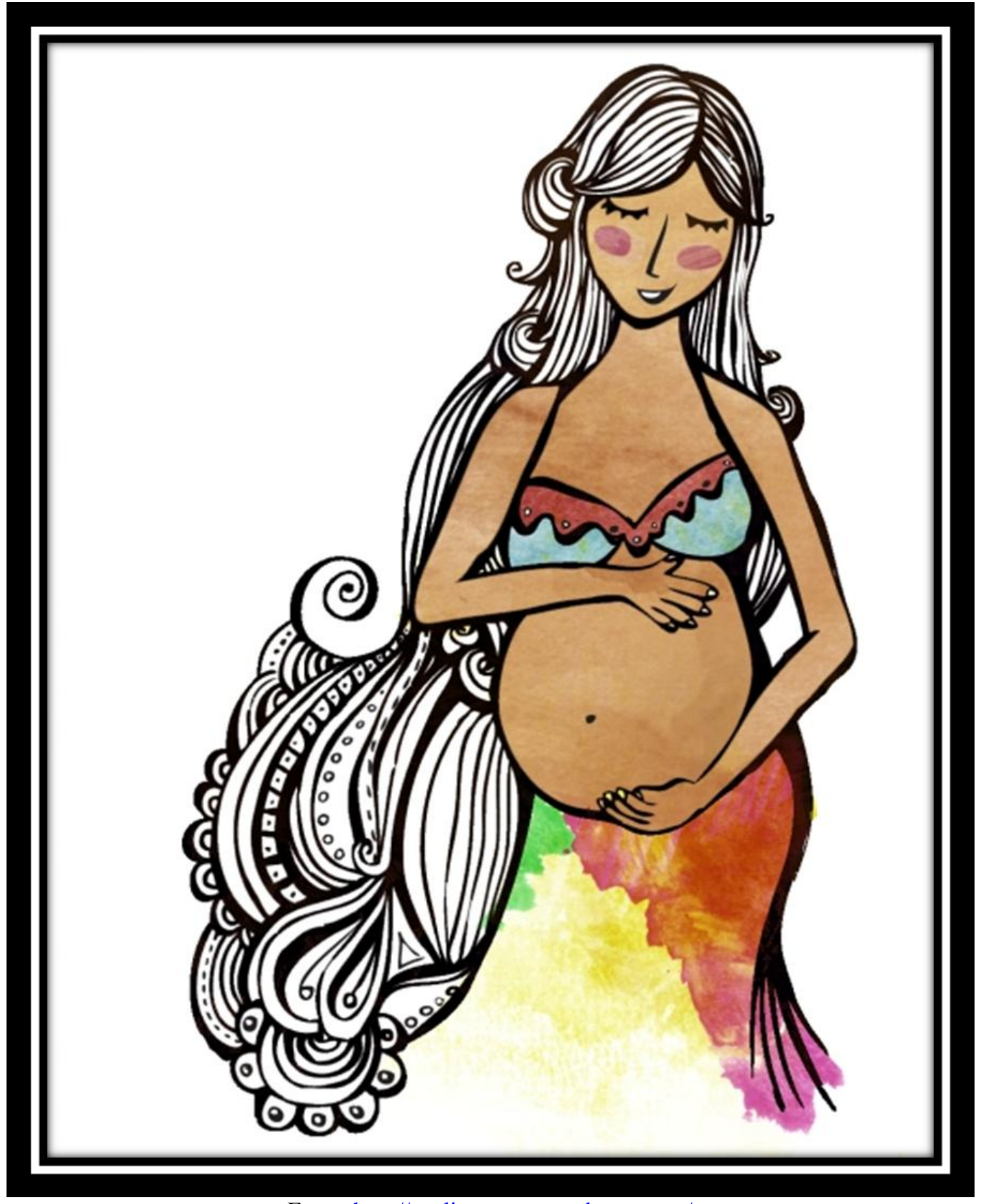

Fonte: http://paulicasantos.wordpress.com/

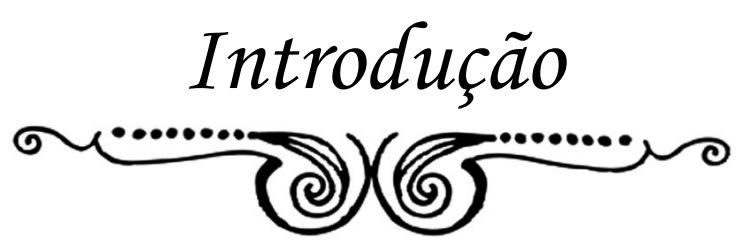


Ao longo do processo histórico, as mulheres dedicam-se à prática do cuidado, porém, com as modificações temporais, o contexto do nascimento foi retirado das "mãos" femininas. Tal fato contribuiu para a incorporação de novas tecnologias e saberes, que passam a ser pautados na autoridade médica e na dominação masculina. Com essa mudança no contexto histórico do nascimento, as práticas de cuidado no ciclo gravídico-puerperal se transformaram e as mulheres foram retiradas de seu ambiente familiar e cultural, tendo que se submeter à legitimidade do saber médicocientífico, que se perpetua ainda no século atual (Kitzinger, 1978; Osava, 1997; Helman, 2003; Melo, 2003; Araújo, 2009).

Quando enfocamos a fase puerperal, verificamos que mesmo sendo considerado um período marcado por mudanças e fragilidades, a prática mostra reduzida atenção dos profissionais para com a mulher nesta fase, o que não ocorre quando comparado aos demais períodos do ciclo gravídico-puerperal (Stefanello, Nakano, Gomes, 2008).Tal constatação também é afirmada por Albers (2000).

Cabe lembrar que as pesquisas na área materno-infantil, realizadas pela enfermagem, tiveram início em meados de 1933; porém, a produção científica se torna relevante a partir de inquietações dos profissionais, como respostas às práticas sociais direcionadas às mulheres. Entretanto, a busca por estudos realizados com recorte no ciclo gravídico-puerperal mostra que são reduzidas as pesquisas, em particular no Brasil, com enfoque no período puerperal, se comparadas às voltadas às fases do pré-natal e do parto (Centa, Oberhofer, Chammas, 2002; Tyrrell, Cabral, 2005; Souto et al., 2007; Kalinowski et al., 2010).

Evidências têm demonstrado que as pesquisas sobre a fase puerperal, quando não tratam da amamentação, são estruturadas com base nas possíveis patologias e intercorrências que podem surgir neste período, tais como hemorragias, transtornos psicológicos e infecciosos, com priorização das intercorrências (Shimo, Nakano, 1999).

Biologicamente, o puerpério, ou pós-parto, corresponde à finalização do parto. Inicia-se com a dequitação, tem fim pouco exato, mas estabelecido em torno de seis a oito semanas, quando o organismo materno retorna às condições prégravídicas (Cunningham et al., 2000; Neme, 2000; Costa, 2001). 
O período puerperal também é conhecido, pela população, como quarentena, dieta ou resguardo, conforme os aspectos socioculturais. Corresponde aos 42 dias após o parto, como demonstrado por Evans (2010). Para Liu et al. (2009), o período puerperal corresponderia aos 30 ou 40 primeiros dias após o nascimento do bebê. É consenso que o puerpério é o período em que o organismo da puérpera se recupera das transformações da gravidez e do parto; por isso, a necessidade de cuidados adequados para que a saúde materna seja restabelecida.

Para além do fisiológico, essa etapa da vida da mulher é marcada por alterações emocionais e psicológicas. Corresponde a um momento de alta vulnerabilidade, não somente pela transferência de papéis da mulher-mãe, mas também pela oscilação de sentimentos, marcada por euforia, medo, alívio e ansiedade, os quais são desencadeados pela regressão gravídica e pelas novas exigências geradas pelo recém-nascido (Merighi, Gonçalves, Rodrigues, 2006).

Esta vulnerabilidade psicológica e emocional da puérpera torna o pós-parto um período crítico e merecedor de atenção dos profissionais e das redes de apoio social à mulher. Sendo assim, as mudanças sociais e fisiológicas, encontradas neste período de transição involutiva, tornam a nova mãe sensível e permeável aos conceitos externos, os quais são construídos pelos elementos do seu cotidiano familiar, social e cultural (Barreira, Machado, 2004).

Devido a essas mudanças, a puérpera também demanda apoio emocional e ajuda na sua prática diária, tanto de redes de contato pessoal quanto profissional; porém, a forma e o modo como essa ajuda será oferecida irão variar de acordo com a época e a cultura vigente (Enkin, 2005). Sendo assim, os cuidados demandados pela maternidade não dependem apenas dos prestados pelos profissionais, mas também dos oriundos da rede de contato sociocultural da mulher (Medina, Mayca, 2006).

Como puérpera e recém-nascido são considerados vulneráveis, ao retornar da maternidade para o espaço familiar levando o filho recém-nascido, a nova mãe se vê diante de situações que sofrem interferência de seu ambiente cultural. Nessa condição, ao se deparar com o saber popular, a nova mãe é impelida a se resguardar, pois o parto é tido como meio do organismo materno se "abrir" e seu "fechamento" só é determinado após o quadragésimo dia de pós-parto. Dessa forma, nesta fase, a visão popular foca-se no cuidado da mulher, que, caso não atendido, levará ao 
adoecimento e a algum desajuste; com isso, muitas mulheres sentem-se convalescentes, mesmo vivendo a normalidade de um período de transição (Heh, 2004; Canaval et al., 2007; Piperata, 2008; Stefanello, Nakano, Gomes, 2008).

Devido a esses cuidados oriundos da prática familiar, as prescrições advindas dos profissionais da área da saúde podem se contrapor ao saber popular, deixando de ser utilizadas pela puérpera, como verificado em estudo realizado por Almeida e Kantorski (2000), no qual se relatou a experiência do cotidiano de cuidados nas maternidades. No estudo, mostrou-se que é necessário conhecer a realidade das puérperas, com relação às suas crenças, aos valores e às práticas culturais, para que o cuidado prestado pelo profissional de saúde seja culturalmente congruente. Sendo assim, esse cuidado deve ser aplicado quando desenvolvido junto aos grupos sociais, ao qual a mãe está inserida. Porém, o desinteresse e a desatenção dos profissionais frente a esse contexto podem gerar o predomínio de orientações de práticas de caráter biológico sobre às de origem sociocultural. Não obstante, nesta condição, afloram-se as crenças oriundas da prática familiar, as quais geram cuidados considerados maléficos ou benéficos, conforme sua orientação de saúde. Tal situação ocorre porque a maternidade é determinada também por valores culturais, afetivos e sociais (Pedroso, 1982; Pelcastre, 2005; Wiegers, 2006).

As crenças, os valores e os tabus são responsáveis por conceber a esfera cultural. Verificamos que o termo "crenças" tem, por definição, o ato de crer e/ou ter convicção por algo; além disso, exemplifica um ato de fé que determina uma convicção íntima, nem sempre ligada a um grupo, mas sim à ordem de uma pessoa; mesmo sem comprovações objetivas, subjetivamente é mantida como princípio para um indivíduo. As crenças também podem ser explicadas como um estilo de conhecimento advindo do senso-comum e interiorizado no humano segundo seus hábitos de vida (Canteiro, Martins, 2004; Holanda, 2004; Ichisato, Shimo, 2006).

As crenças culturais acerca do período gestacional e pós-natal são instituídas secularmente, como formas de cuidados e proteção da mãe e do bebê, que estariam vulneráveis devido às transformações biológicas, sociais e culturais; entretanto devemos policiá-las para que não sejam nocivas ou patogênicas (Helman, 2009).

À luz da atuação do profissional de saúde, notamos que tanto as pesquisas quanto as práticas cotidianas no período pós-parto são, em sua maioria, baseadas no 
modelo biomédico, pois ainda predomina a crença que apenas a esfera biológica é determinante para as mudanças encontradas nesse período; com isso, evidenciam-se, no atendimento do profissional, os aspectos extremamente técnicos e a desvalorização das demandas culturais e sociais da mulher-mãe (Cabral, Oliveira, 2010).

Uma das causas para o desfavorecimento do contexto sociocultural da mulher ocorre porque, tanto o profissional, quanto a clientela, mesmo fazendo parte de uma cultura hegemônica, entendem os agravos de saúde de maneira diferente. Ao se considerar a diversidade de valores e de crenças próprias do indivíduo, que se confronta com a formação acadêmica, que tem como modelo a determinação da cura acima de qualquer situação emocional ou cultural, observa-se a geração de um vínculo verticalizado entre profissional e cliente, no qual as práticas de cuidados são fundamentadas na racionalidade científica, uma vez que a explicação de um estado de saúde ou doença baseada em aspectos culturais, com enfoque em crenças, não seria tão objetiva e certa como um resultado fornecido por um exame laboratorial ou clínico (Helman, 2003).

Ainda segundo Helman (2009), o reducionismo biomédico faz com que a pessoa seja vista de maneira compartimentada. A família e a comunidade são esquecidas durante esse processo, o que acaba tornando a interação médico-cliente ainda mais frágil.

Quando o profissional fundamenta seu cuidado apenas segundo seus conhecimentos científicos, considera-se que sua prática é baseada em uma "cegueira" cultural, pois, com essa atitude, o cuidador tenta impor seus preceitos acima dos da cliente (Gualda, 1993; Araújo, 2009).

A puérpera, diante deste quadro, tende, por curto período de tempo, a seguir os preceitos de cuidados oferecidos pelo profissional; porém, após essa temporalidade, ela reassume seu estilo de vida, considerando os padrões culturais próprios de seu contexto. As divergências advindas desta comparação podem deixála insegura sobre a escolha do tipo de cuidado ideal (Gualda, 1993).

A observação na prática, acrescida de resultados de pesquisa, demonstra que nem sempre os profissionais valorizam a influência sociocultural no período puerperal. A família, por conviver no mesmo contexto da puérpera, exerce seu papel 
de complementação da atuação do profissional. Nesta atmosfera, o apoio dos familiares torna-se valioso para as decisões sobre o cuidado da mulher no período puerperal, principalmente quando advindo do marido/companheiro e das avós, em especial do lado materno (Merighi, Gonçalves, Rodrigues, 2006; Rapoport, Peccinini, 2006).

Frente ao contexto da "cegueira" cultural na atmosfera assistencial, são encontradas lacunas na assistência no período puerperal, que prejudicam o atendimento integral da mulher, se julgarmos a dissociação entre natureza e cultura que deixam de compor um conjunto (Almeida, Novak, 2004; Takushi et al., 2008). Dessa forma, verificamos uma incompletude das práticas de cuidado no pós-parto, quando estas são ofertadas pelos profissionais, que se fundamentam, em sua maioria, apenas no lado biológico e instintivo da mulher, sem solucionar suas dúvidas demandadas por outras esferas, como sociais e culturais (Catafesta et al., 2007).

Por conta do exposto, e associado às dificuldades geradas por novas demandas, a puérpera é impelida a buscar auxílio na rede social à qual se insere, em detrimento das informações que recebeu durante o pré-natal ou na assistência na maternidade. Essa valorização dos preceitos familiares em oposição aos conceitos biomédicos surge também porque aqueles estão presentes no contexto de vida da pessoa desde o nascimento e estes influenciam no seu modo de ser, o que não difere no período pós-parto (Ichisato, Shimo, 2006; Takushi et al., 2008).

O setor informal, que também é caracterizado pela família, responsabiliza-se por cuidar de $70 \%$ a $90 \%$ da saúde nas sociedades ocidentais e orientais. Isso ocorre, pois a rede de contato - em particular, os familiares - possui vivências, valores e crenças semelhantes aos da cliente, o que geraria maior aceitação e durabilidade dos cuidados prestados por estes (Nakamura, Martin, Santos, 2009).

A condição acima é confirmada por estudo qualitativo com enfoque na vivência da amamentação de mães com recém-nascidos prematuros, realizado no município de São Paulo, que verificou que, na perspectiva das mães, a qualidade da atenção gerada pela equipe de saúde só se faz completa quando os profissionais realizam o acolhimento englobando, além das necessidades maternas, a demanda do contexto familiar e social desta puérpera frente aos cuidados com o filho (Silva, Silva, 2009). 
Vale destacar outro estudo qualitativo sobre representações sociais maternas e introdução de alimentos complementares para lactentes, no qual se verificou que o médico gera diretrizes validativas sobre os cuidados advindas do senso comum; assim, a escolha da introdução de alimentos do bebê sofre interferência da experiência da mulher-mãe e de seu contexto sociocultural. A justificativa reside no fato da mulher-mãe passar por um período importante de aprendizado, o que culmina na preferência dos valores culturais aos quais foi criada fazendo com que a lógica dos saberes científicos, advindos do profissional de saúde, seja colocada à parte (Salve, Silva, 2009).

Sendo assim, a influência familiar, gerada pela herança construída nos contextos socioculturais, associa-se à necessidade de auxílio da puérpera. Neste contexto, as crenças baseadas em mitos e tabus adquirem força e tendem a se manifestar no comportamento da mulher em pós-parto (Canteiro, Martins, 2004; Vaucher, Durman, 2005).

Bitar (1995) relata que desde o momento do nascimento, o ser humano traz consigo duas configurações: a genética e a cultural. A primeira é responsável por transmitir as características hereditárias, enquanto a segunda configura a transmissão de valores e crenças.

Sabe-se que a esfera cultural atrela-se não só aos aspectos mitológicos, mas também às crenças e aos tabus (Ichisato, Shimo, 2006). Esse conjunto, formado pelos três elementos - mitos, tabus e crenças -, embora complexo, pode ser resumido como um estilo de conhecimento advindo do senso comum e interiorizado pela pessoa segundo seus hábitos de vida (Canteiro, Martins, 2004; Henriques, Gomes, 2005).

Mesmo sendo considerados como um saber primitivo, os mitos e os tabus se perpetuam nas gerações como uma forma de manutenção de seu passado e explicam o mundo cultural da pessoa com base em suas crenças (Castilho, 2003; Vaucher, Durman, 2005; Grimal, 2009).

As crenças são consideradas uma forma de conhecimento, que se incorpora ao indivíduo, a partir de seus hábitos e costumes de vida, e, que uma vez interiorizada no seu cotidiano, permite a continuidade diária de seus preceitos, que determinam a sua maneira de ser e de agir. Sendo assim, se a pessoa acreditar que 
algo irá lhe fazer mal, isso pode ocorrer, pois, as crenças são alimentadas pelo modo de pensar da pessoa e dependem da forma que são incorporadas por ela, influenciando e estabelecendo o bem ou o mal-estar da pessoa envolvida. Pode-se, ainda, depreender que a crença é oriunda da construção familiar, com o intuito de promover perseverança e sustentar as regras parentais (Collière, 1989; Gualda, Bergamasco, 2004).

As crenças podem surgir a partir de mitos, os quais são considerados lendas ou histórias, contrariando o logos, ou seja, o raciocínio. Ao se incorporar em uma população, mesmo mantendo seu modelo tradicional, as crenças sofrem modificações para que os indivíduos consigam entender seu contexto, variando de acordo com cada cultura (Grimal, 2009).

Uma das causas das crenças se manterem vivas mesmo depois de séculos se deve à transmissão entre gerações, ou seja, a partir de perspectivas intergeracionais, as quais as segregam, por meio de expressões simbólicas, mediadas por imagens, contos, cartas e valores, transmitidos de maneira que envolvem a parte afetiva e emocional do ser humano (Brandão et al., 2006; Pátaro, 2007).

Por sua vez, os mitos e os tabus delimitam crenças familiares, as quais surgem por meio das relações entre os parentes e têm a finalidade de cooperar para a formação da identidade cultural do círculo familiar, o que ajuda a potencializar a permanência deste saber no mundo (Castilho, 2003).

As tradições familiares, compostas também pelos próprios mitos e crenças, são responsáveis por conduzirem o pensamento humano, pois são contabilizadas como verdades absolutas e, por meio dos laços geracionais, segregam as perspectivas mitológicas e lendárias (Henriques, Gomes, 2005; Pátaro, 2007; Cotta, Priori, Marques, 2008). No Brasil, país constituído por culturas e etnias diversas, o conhecimento popular e as tradições se manifestam nos aspectos biopsicossociais, também durante o ciclo gravídico-puerperal (Centa, Oberhofer, Chammas, 2002).

Neste contexto, a oposição entre o saber científico e as crenças familiares faz com que a puérpera vague entre duas lógicas opostas. Devido ao desequilíbrio do saber científico ao ser confrontado às crenças herdadas da família e de seu meio sociocultural, o saber popular se sobrepõe e faz aflorar crenças que, no puerpério, 
podem modificar o cotidiano de cuidados dessa mulher (Stefanello, 2005; Baião, Deslandes, 2006).

As crenças, neste contexto, surgem na prática do cuidado como uma forma de proteção do binômio mãe e recém-nascido, que se encontra vulnerável pelos eventos do ciclo gravídico-puerperal (Nakano et al., 2003). Essa mesma visão é encontrada em outras culturas, como na japonesa, na qual as práticas de cuidados são pensadas e perpassadas entre gerações com o intuito de beneficiar o binômio mãe-bebê (Raven et al., 2007).

Cabe citar que autores que estudaram crenças, mitos e tabus no período pósparto destacam que as maiores influências nas práticas de cuidado nesta fase são transmitidas pelos familiares mais velhos da puérpera (Liu et al., 2009). Um estudo mostrou que as participantes ouviram a opinião de várias redes de contato, sobre os danos à elasticidade vaginal, mas valorizaram seu contexto, na qual a opinião de mulheres da família, em especial a mãe e a avó, teve relevância (Araújo, 2009). Esta opção demonstra a tendência em seguir a orientação advinda da tradição familiar pautada nas perspectivas intergeracionais. Estudo realizado por Rico (2006) apontou que, além da transmissão entre as gerações, ainda há redes sociais formadas por amigos e também os meios impressos e eletrônicos, dentre estes, o rádio, a televisão, as revistas, e a internet, os quais transmitem as informações de cuidados no pósparto.

Portanto, o ciclo gravídico-puerperal deve ser visto como uma fase permeada por crenças, mitos e tabus devido a transformação e a autodefinição de um novo papel na vida da mulher e da família (Rapoport, Piccinini, 2006; Ciampo et al., 2008). Vemos o período pós-parto como uma condição em que a mulher sofre interferência das ações dos profissionais de saúde e da própria família e de sua rede de contato. Sendo assim, as orientações recebidas quanto ao cuidado no período pósnatal devem atender às esferas biopsicossocioculturais, para que, frente à uma demanda de cuidado, a puérpera consiga discernir qual a melhor prática a ser escolhida dentre o saber científico e o popular, para obter o melhor resultado na sua recuperação.

Do exposto, consideramos que, ao verificar as opções da puérpera diante de dois pólos - orientações biomédicas e crenças do seu contexto de vida - sobre as 
práticas de cuidado no pós-parto, estaremos contribuindo com serviços de maternidade, desvelando caminhos para a assistência biossociocultural da clientela, e oferecendo à mulher-mãe a oportunidade de vivenciar o momento do pós-parto, de maneira responsável e autônoma diante das práticas de cuidado.

Dessa forma, o presente estudo buscou respostas à questão:

No cotidiano da mulher que vivencia o período pós-parto, suas práticas de cuidado derivam de crenças populares, de informações de cunho científico ou de ambas?

Diante da perspectiva de que estaríamos trabalhando com práticas derivadas de orientações de cunho científico e transmissão popular, optamos pelo Modelo de Competência Cultural de Purnell como referencial teórico, pois este estuda o receptor e seu contexto, assim como o provedor de cuidado à saúde e a relação entre ambos. 

O Modelo de Competência Cultural de Purnell surgiu na década de 1990, com a intenção de favorecer um ambiente de cuidado que propiciasse captar crenças e valores presentes na sociedade, de modo a auxiliar o profissional da área da saúde na prestação do cuidado ao cliente, não apenas no aspecto biológico, mas também sociocultural (Purnell, 2000).

Este Modelo de cuidados visa entender os profissionais de saúde, em particular, a enfermeira, frente ao processo de cuidado; por isso, sua relação com o cuidar humano nas três esferas da saúde: primária, correspondente à promoção da saúde; secundária, que envolve a prevenção e a proteção à saúde, e terciária, que envolve a reabilitação por meio do multiculturalismo entre a relação profissional e cliente (Purnell, 2000; Marroni, 2003).

Este Modelo de Competência Cultural busca evitar generalizações, uma vez que estas fazem os indivíduos perderem a personalidade própria, levando à minimização do único em prol do todo e gerando simplificação das crenças e valores das pessoas (Marroni, 2003; Purnell, 2005).

Sendo assim, o Modelo preza pelo respeito aos aspectos sociais e culturais tanto do indivíduo como dos profissionais, propondo a observância dos valores culturais para a efetivação de um cuidado integral para o restabelecimento da pessoa. Quando os aspectos culturais não estão interligados às práticas de cuidado, o cliente pode sentir-se desrespeitado pelo profissional que presta este atendimento, gerando um possível prejuízo na credibilidade deste cuidador (Purnell, 2000; Marroni, 2003).

O Modelo permite ao profissional conhecer as crenças e os valores próprios para não gerar interferência cultural, mas também favorece a investigação das crenças e dos cuidados individuais das clientes; dessa maneira, de posse do histórico cultural da cliente, as intervenções de saúde seriam delineadas, aperfeiçoando a experiência do cuidado (Purnell, 2005).

Os modelos que envolvem competência prezam pela aceitação e pelo respeito das diferenças, mantendo a individualidade do sujeito em relação às crenças próprias. Por conta disso, o profissional deve conhecer e entender a cliente para conceber práticas de cuidados culturais, baseando-os na origem, no comportamento, nas crenças e nas atitudes da clientela (Purnell et al., 2011). 
O citado Modelo foi criado tendo como base disciplinas da área de humanidades e da saúde, assim como conceitos sobre o ambiente. O Modelo de Competência Cultural de Purnell (Figura 1) é composto por doze domínios culturais, microaspectos que se relacionam entre si, em maior ou menor grau, e com cada dimensão, macroaspectos, do citado Modelo (Purnell, 2000).

\section{The Purnell Model for Cultural Competence}

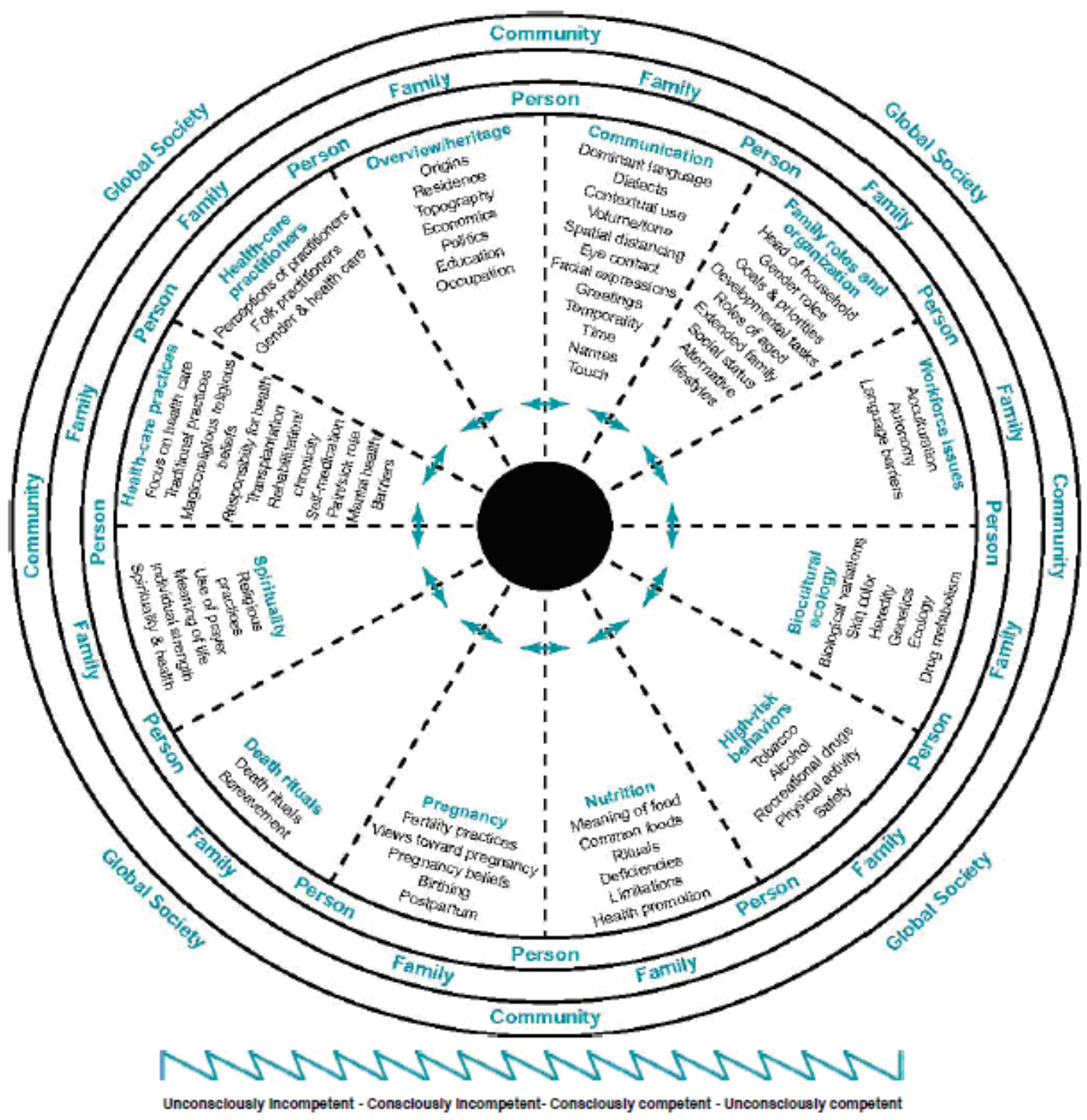

FIGURA 1 - Modelo de Competência Cultural de Purnell representado na forma de círculo com as dimensões globais, ou macroaspectos, e os 12 domínios, considerados microaspectos.

Fonte: Purnell, 2000. 
Neste Modelo, são considerados os macroaspectos, como: Sociedade Global, Comunidade, Família e Pessoa, tanto nos setores educacionais, como na pesquisa e também na saúde. Para os autores deste Modelo, saúde é definida como bem-estar em relação aos aspectos biossocioculturais e étnico-culturais, levando em consideração a influência da globalização, da sociedade e dos familiares sobre o indivíduo (Purnell, 2000; Marroni, 2003).

No Modelo, a comunidade caracteriza-se como um grupo de pessoas com interesses comuns, que vivem em dado local; enquanto a família é tida como um conjunto de duas ou mais pessoas, com envolvimento emocional mútuo; e a pessoa é considerada como ser biopsicosociocultural em constante transformação. Quanto à dimensão global, esta sofre influência da disseminação de eventos por meios da comunicação (Purnell, 2000).

Como microaspectos deste Modelo, são considerados os 12 domínios (Figura 1), que são conceituados seguindo o multiculturalismo e a influência sobre a saúde do indivíduo, sendo eles: herança, comunicação, papéis e organização familiar, força de trabalho, ecologia biocultural, comportamentos de alto risco, nutrição, práticas na gravidez, no parto e no puerpério, rituais relativos à morte, espiritualidade, práticas de cuidado à saúde e, por fim, provedor do cuidado à saúde (Purnell, 2000; Purnell, 2005).

O Modelo ainda prevê sua responsabilidade ao criar um ambiente favorável de acolhimento com vistas às práticas clínicas, com o intuito de identificar crenças e valores para desenvolver registros de cuidados baseados em acordos entre profissional e cliente (Purnell, 2000; Marroni, 2003; Purnell, 2005).

Sendo assim, o Modelo representado na figura 1 mostra cada domínio e seu conteúdo. Dessa maneira, apresentamos, a seguir, os 12 domínios do Modelo de Competência Cultural de Purnell, com seus conceitos, segundo Purnell (2000), Marroni (2003), Purnell (2005) e Alvarez (2012):

\section{Herança}

Neste domínio, também conhecido como Visão do Mundo, verificam-se os aspectos relacionados a alguns dados socioeconômicos e culturais tanto da pessoa, como da família e comunidade, aqui representados pelos modelos de moradia, as 
situações políticas e econômicas, os níveis educacionais, índices de trabalho e ocupação, além das relações com os aspectos migratórios.

Pode-se verificar, como exemplo, migrações relacionadas às questões econômicas, ou seja, a busca por uma ocupação mais rentável, que pode estar relacionada ao grau maior de escolaridade.

Sendo assim, esse domínio busca correlacionar tais aspectos do mundo às modificações sociais, culturais e espaciais das pessoas e da sociedade.

\section{Comunicação}

Este domínio relaciona-se diretamente aos demais, uma vez que o uso da linguagem colabora para as relações e o conhecimento humano.

Sendo assim, as variações linguísticas, além das formas de comunicação verbalizada e não-verbalizada, as diferentes entonações da vocalização e a classificação por nomes são contempladas neste domínio, visando explicar as complexidades do padrão da linguagem nas relações sociais.

A linguagem e os meios de comunicação são de extrema importância, ao avaliar como o prestador de cuidado realizaria orientações em comunidades com linguagem diferente do seu idioma de origem, mostrando que a comunicação, além de estar associada à identidade de um povo, pode caracterizar barreiras socioculturais quando não dominada na totalidade pela sociedade e pelo indivíduo.

\section{Papéis e organização familiar}

Neste domínio, são atribuídos a relação do gênero na chefia familiar, assim como o lugar da família na comunidade, segundo o estilo de vida dos sujeitos envolvidos na constituição familiar.

É possível avaliar os papéis familiares, assim como a constituição do casamento ou somente a união informal com um companheiro, o que representaria a forma pela qual tanto a sociedade quanto a família e o indivíduo concebem a relação da organização familiar.

Ainda como exemplo, destaca-se a relação das disparidades entre os gêneros e a formação das famílias e a classificação entre diferentes papéis e desempenhos na organização dos membros familiares. 


\section{Força de trabalho}

Neste domínio, encontra-se a relação entre as formas de trabalho do indivíduo e a família e a sociedade. Podemos verificar a autonomia e a aculturação, ou seja, a fusão de várias culturas interferindo no processo do trabalho.

Além disso, pode-se interpretar os papéis de gênero e a influência do país de origem sobre as práticas de saúde e trabalho.

Sendo assim, as formas de trabalho poderiam auxiliar a entender o indivíduo, a família e a sociedade frente esta constituição.

\section{Ecologia biocultural}

Este domínio contempla desde as variações étnicas, raciais e culturais até as diferenciações no organismo humano, por conta das diferentes raças.

Também como parte deste domínio, buscam-se identificar e explicar as doenças de cunho genético e hereditário e a ação dos medicamentos sobre os metabolismos.

Exemplificando: a ecologia biocultural pode analisar a cor de pele em relação ao indivíduo, à família e à sociedade, buscando compreender os eventos sobre a esfera biossociocultural.

\section{Comportamentos de alto risco}

Refere-se à avaliação de hábitos culturais que ofereceriam riscos para a saúde do indivíduo, como: etilismo, drogadição e tabagismo; ausência de atividade física, ingestão em excesso de calorias e falta de medidas para prevenção de risco.

Este domínio busca investigar no indivíduo, na família e na sociedade os hábitos ou as atividades que geram riscos; por exemplo, falta de equipamentos de segurança quando se realiza uma atividade que envolva risco ao organismo.

\section{Nutrição}

Trata da escolha pelo alimento, além de envolver os rituais e os tabus alimentares. Esse domínio fornece dados sobre o significado do alimento, assim como a utilização da nutrição para promover e restabelecer a saúde do indivíduo. 
Como o alimento recebe diferentes designações segundo a cultura, a sociedade, a família e o indivíduo, ao se reconhecer os diferentes significados atribuídos, propicia-se maior conhecimento sobre a prática nutricional.

\section{Práticas na gravidez, parto e puerpério}

Refere-se às práticas relacionadas a crenças e tabus presentes no período gravídico-puerperal, assim como a vivência destas etapas, o uso de métodos de controle da natalidade e o padrão de fertilidade.

Verificam-se, ainda, as práticas restritivas e prescritivas sobre as etapas do ciclo gravídico-puerperal.

Exemplificando a perspectiva do domínio: as crenças acerca do período puerperal interferem no sujeito, na família e na sociedade; ao conhecê-las, estabelece-se um padrão integral de cuidado.

\section{Rituais relativos à morte}

Pretende-se, ao se avaliar este domínio, encontrar a maneira pela qual os indivíduos, a família e a sociedade explicam e entendem o ato de morrer.

Além disso, leva-se em consideração o envolvimento cultural na preparação e na condução do enterro e do sepultamento, além da valorização do corpo físico.

\section{Espiritualidade}

Englobam as práticas relacionadas à religião, assim como as formas de oração e o significado da vida, segundo os aspectos da espiritualidade atribuídos pela força da fé.

\section{Práticas de cuidado à saúde}

Envolvem a prevenção e o tratamento de um agravo, assim como práticas com fundamentação biomédica e crenças populares, responsabilidade individual pela própria saúde, automedicação e barreiras para a manutenção da saúde.

\section{Provedor de cuidado à saúde}


Os provedores de cuidado à saúde são vistos sob a ótica de práticas mágicoreligiosas, biomédicas e tradicionais na promoção ou no restabelecimento da saúde.

Partindo da descrição dos domínios acima expostos, o referido Modelo propõe que a enfermagem incorpore, na prática clínica, a realidade sociocultural dos clientes e, a partir da atenção a seus domínios, favoreça o cuidado prestado.

Ao optarmos pelo Modelo de Competência Cultural de Purnell como referencial de análise deste estudo, consideramos que a pessoa deve ser investigada como ser social e cultural, pois as regras sustentadas por uma sociedade apenas se mantêm vigentes devido à ação simbólica transmitida culturalmente entre as gerações. Em grande parte das sociedades humanas, as crenças, os valores e as práticas relacionam-se à manutenção da saúde, características fundamentais de uma cultura (Helman, 2003).

Consideramos, também, que o ser humano é responsável por regular e perpetuar seus princípios, sendo assim, é a partir da vivência social e cultural da pessoa que será determinada sua visão de mundo, segundo suas práticas e crenças. Cultura seria, portanto, um conjunto de preceitos herdados por uma pessoa em resposta ao convívio com seu grupo sociocultural, o qual delimitaria o modo de ver e experienciar o mundo junto de forças do ambiente sociocultural ao qual está inserida (Helman, 1994; Helman, 2003).

A cultura é responsável pela transmissão dos princípios sociais para as gerações seguintes, por meio de símbolos e de rituais, nos quais os aspectos culturais ajudariam a pessoa a compreender o mundo ao qual se insere para conviver nele, embora nem sempre a cultura na qual o sujeito nasce e vive seja o único meio de influência sobre o padrão saúde-doença, mas sim, uma das formas de interferência sobre o comportamento, as crenças e os padrões de estilo de vida do indivíduo (Helman, 2009).

Com esta compreensão da vivência em uma sociedade globalizada, na qual os cuidados à saúde exigem o atendimento biossociocultural do cliente, julgamos adequado o emprego do Modelo de Competência Cultural de Purnell (Purnell, 2000). Este Modelo volta-se ao recipiente e ao provedor do cuidado à saúde, que, nesta pesquisa, são representados, respectivamente, pela mulher que vivencia o pós-parto e 
pelo profissional de saúde (ou o leigo) que pode assisti-la em suas demandas de cuidados à saúde.

Segundo a revisão da literatura e o questionamento da pesquisa, e prezando pela abordagem qualitativa e utilização do referencial teórico do Modelo de Competência Cultural de Purnell, o presente estudo almeja responder o objetivo disposto a seguir. 


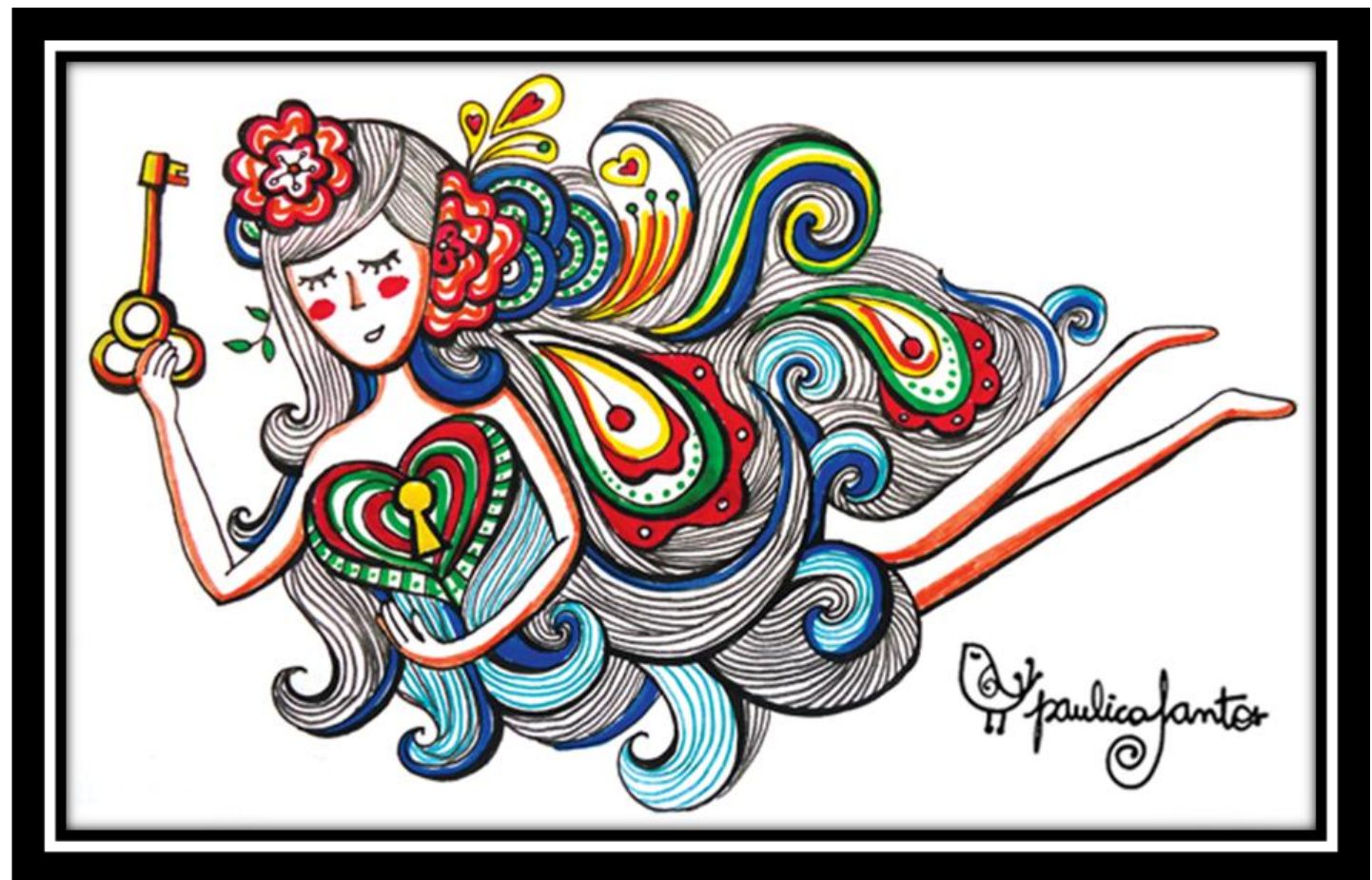

Fonte: http://paulicasantos.wordpress.com/

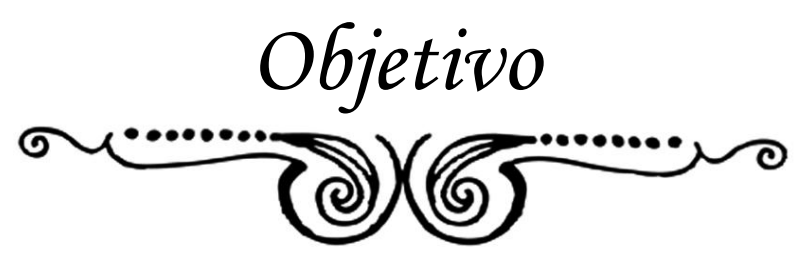


- Explorar as práticas de cuidado adotadas no pós-parto pela mulher usuária de uma Unidade Básica de Saúde na cidade de Rio Claro, SP. 


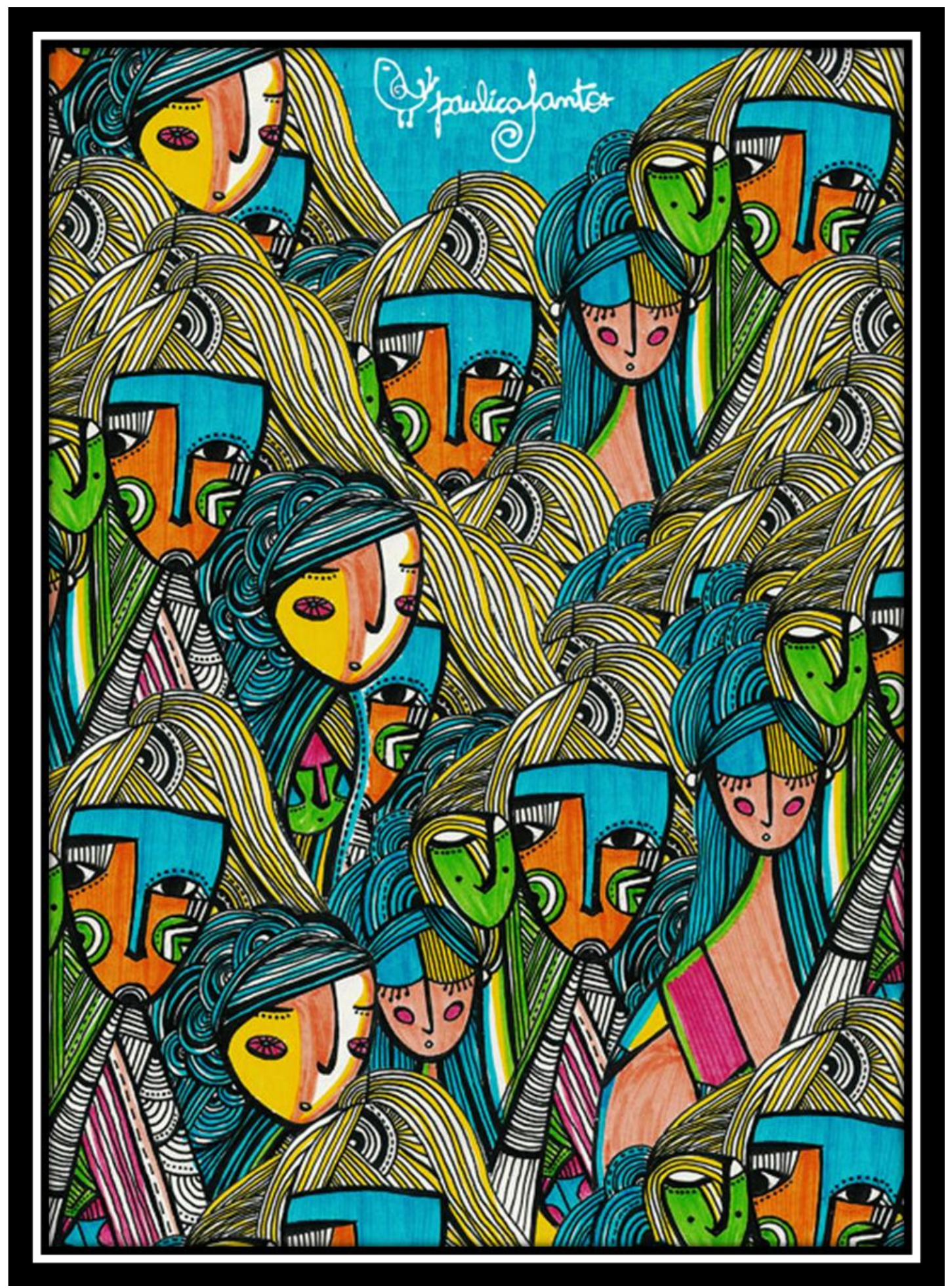

Fonte: http://paulicasantos.wordpress.com/

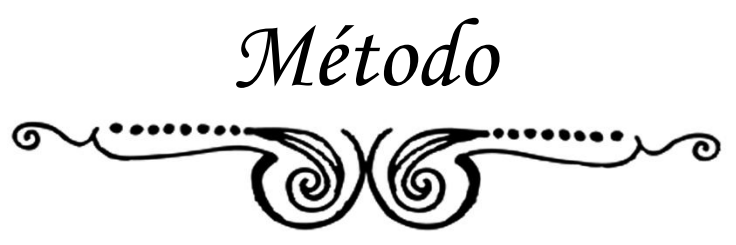


Este é um estudo qualitativo, que teve como referencial de análise o Modelo de Competência Cultural de Purnell e que utilizou o Discurso do Sujeito Coletivo como método para tratamento e apresentação dos dados encontrados por meio de entrevista gravada.

\section{Local}

O estudo foi realizado no município de Rio Claro (SP), junto às puérperas usuárias de uma Unidade Básica de Saúde (UBS) escolhida por atender elevado número de consultas de pré-natal: aproximadamente 159 gestantes em maio de 2010 (Brasil, 2010b).

Esta UBS localiza-se na área urbana, é referência para 32 bairros do município, além de contar com uma unidade de pronto atendimento anexa. Cabe salientar que no município de Rio Claro contamos com 6 UBS, nas quais se desenvolvem os programas tradicionais de saúde frente a promoção, a prevenção, o tratamento e a reabilitação do cliente. Além disso, temos 9 Unidades de Saúde da Família (USF), as quais possuem no total 11 equipes de saúde baseadas no Programa Saúde da Família (PSF), as quais atuam nas regiões específicas de cada bairro e/ou setor de saúde, pontuados no mapa municipal (APÊNDICE A) (Rio Claro, 2012).

A cidade de Rio Claro dista $173 \mathrm{~km}$ de São Paulo, capital do estado, tem população de 191.866 habitantes, com taxa de urbanização de 97,6\%. O número de mulheres é de 85.986 e a taxa de fecundidade é de 2,7 filhos/mulher (IBGE, 2009a). No município existe apenas uma referência hospitalar pública, para onde a parturiente é encaminhada. Esta maternidade pública realiza cerca de 160 partos/mês. Entre os meses de abril e julho de 2008 foram realizados 159 cesarianas e 240 partos normais (Grupo Jornal Cidade, 2008).

Segundo a Secretaria Estadual de Saúde de São Paulo, a relação entre partos normais e cesáreas no município de Rio Claro se inverteu, pois, em 2010, foram realizadas 1.634 cesarianas, contra apenas 696 partos normais, demonstrando a influência da medicalização no serviço de saúde do município naquele ano (G1, 2012).

No município, durante o ciclo gravídico-puerperal, as mulheres são acompanhadas pelo sistema SIS pré-natal do governo do Estado de São Paulo, de 
acordo com o Programa de Humanização do Pré-Natal e Nascimento (PHPN), o qual visa garantir maior captação e qualidade nas consultas de pré-natal, assim como atendimento no parto e em todo o período pós-parto. A gravidez e o puerpério são acompanhados nas UBS ou nas USF (Brasil, 2002; Brasil, 2010b).

O parto é garantido no hospital e maternidade municipal de Rio Claro. O serviço de saúde do município estrutura-se de modo que toda puérpera, entre o $7^{\circ}$ e o $10^{\circ}$ dias de pós-parto, seja atendida na UBS onde realizou o pré-natal, cuja finalidade é realizar a revisão do parto e avaliação do período pós-parto, que ocorre no intervalo entre a alta hospitalar e a primeira consulta puerperal e do recém-nascido, também na UBS, em torno de 30 a 40 dias (Brasil, 2002; Brasil, 2010b).

\section{Participantes}

Participaram do estudo puérperas entre $30^{\circ}$ e $45^{\circ}$ dias de pós-parto, que realizaram o pré-natal na UBS campo de estudo.

Não houve definição prévia do número de participantes, pois, por se tratar de um estudo qualitativo, a coleta de dados é que delineou a necessidade do número de entrevistas, pois o encerramento ocorreu quando houve repetição dos dados coletados - saturação teórica.

Os critérios de inclusão para as participantes foram:

1- Estar matriculada e ter realizado pré-natal na UBS, campo do estudo.

2- Estar entre o $30^{\circ}$ e $45^{\circ}$ dias de pós-parto.

3- Ser primípara.

4- Ter idade igual ou superior a 18 anos.

5- Ter tido recém-nascido vivo.

\section{Coleta de dados}

Os dados foram coletados entre os meses de agosto e dezembro de 2011, após autorização da direção do campo de coleta (APÊNDICE B), seguindo as etapas dispostas abaixo, representadas na figura 2. 


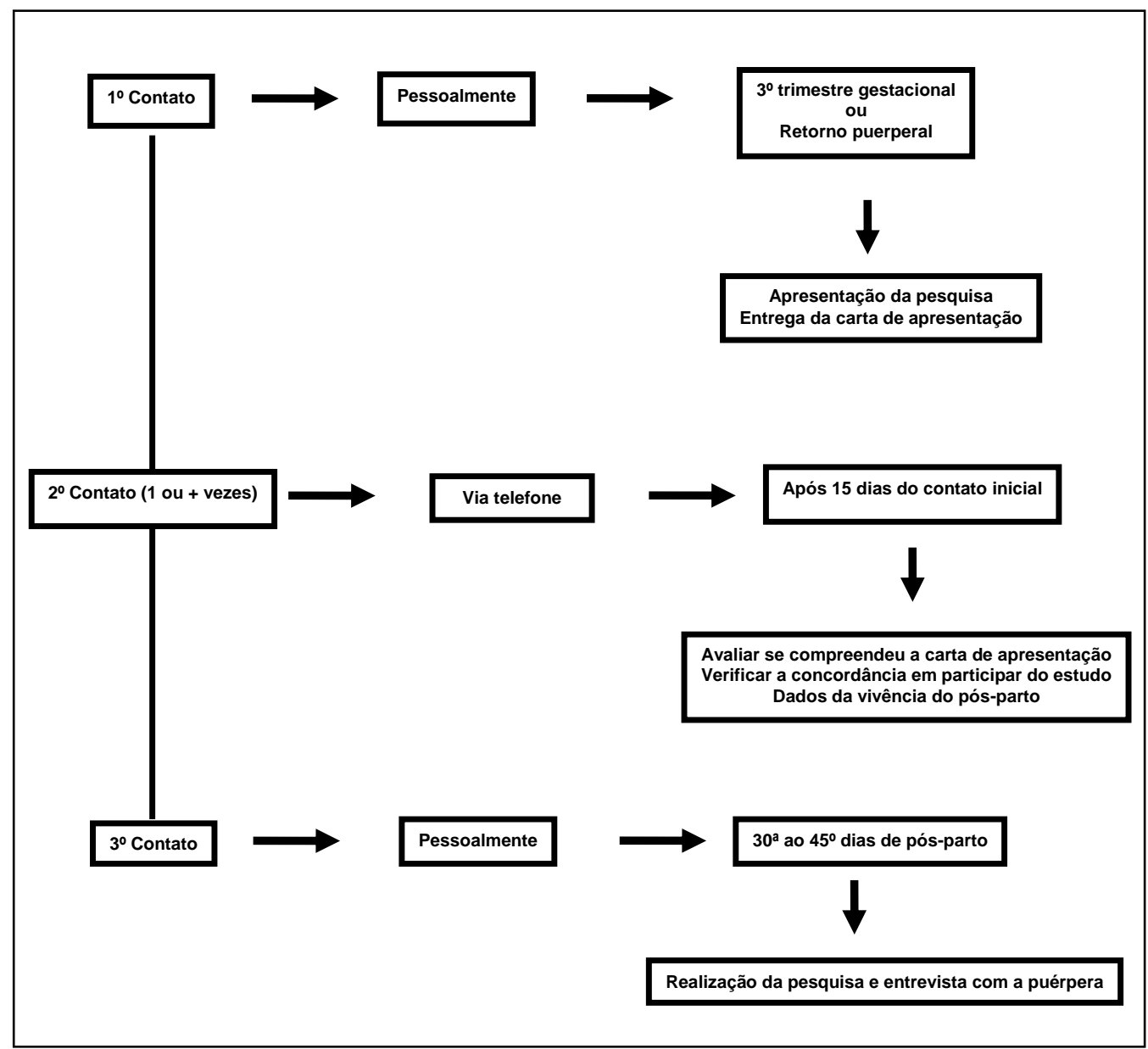

FIGURA 2 - Organograma das etapas para coleta de dados. São Paulo, 2012.

Foram catalogadas 23 puérperas inscritas na UBS de escolha e que preencheram os critérios de inclusão; entretanto, uma se recusou a participar, enquanto outras duas mulheres aceitaram a participação, porém não compareceram no dia agendado para entrevista, além de não termos conseguido novo contato para reagendamento. Dessa forma, participaram deste estudo 20 puérperas.

Para o estabelecimento de vínculo entre pesquisador e participante da pesquisa, foi realizado o $1^{\mathrm{o}}$ contato com a mulher na UBS, antes ou ao final da consulta obstétrica, quando a gestante se encontrava no $3^{\circ}$ trimestre da gravidez. Quando puérpera, este contato foi realizado durante a consulta de revisão pós-parto, entre o $7^{\circ}$ e $10^{\circ}$ dias de puerpério.

Esse primeiro contato foi rápido e realizado em um consultório ou na própria sala de agendamento de consulta nas dependências da UBS. Ainda assim, foram prezados a privacidade e o sigilo. Durou cerca de 10 minutos, tempo para que a pesquisadora se apresentasse e expusesse à mulher o objetivo da pesquisa, além de 
entregar-lhe uma carta de apresentação escrita (APÊNDICE C), com um resumo da pesquisa para que ela pudesse ler com calma e averiguar o interesse em participar do estudo. Foi aberto um espaço de tempo para que a mulher pudesse sanar suas dúvidas frente aos procedimentos da pesquisa. Nesse primeiro contato, também foi preenchida, segundo sua concordância, a ficha de identificação da puérpera (APÊNDICE D) com dados para os contatos seguintes - nome, endereço, telefone, data do próximo retorno à UBS - e preferência de dia, hora e local para a participação na pesquisa.

O $2^{\circ}$ contato foi realizado pelo telefone, após o nascimento do bebê ou aproximadamente 15 dias após o primeiro contato. Em alguns casos, foram realizadas várias tentativas, conforme a necessidade e o pedido da puérpera. Nesse contato, eram questionadas a leitura e a compreensão da carta de apresentação (APÊNDICE C) e sanadas as possíveis dúvidas; diante da concordância em participar, eram combinados local, hora e data para a entrevista.

O último contato foi realizado no dia estipulado pela puérpera para a entrevista. A maioria ocorreu antes ou após a consulta de retorno puerperal, 40 dias após o parto. O tempo previsto para as entrevistas gravadas girou entre 40 e 60 minutos. Quando realizada na UBS, ocupava-se um consultório na ala da pediatria. Nos casos em que a entrevista foi realizada no domicílio, era solicitado um local com privacidade.

A entrevista iniciava-se com a leitura do Termo de Consentimento Livre e Esclarecido (TCLE) (APÊNDICE E), com esclarecimento de dúvidas, sempre que necessário. Após assinatura e entrega da via para a puérpera, esta era convidada a escolher uma entre três figuras compostas por pequenas histórias de deusas para que pudessem ser reconhecidas por estas na apresentação dos resultados da pesquisa. A escolha pela mulher poderia recair tanto no desenho da deusa como por sua história ou por ambos.

Os dados foram obtidos por meio de entrevista com respostas para um formulário semiestruturado (APÊNDICE F) e se iniciava após a escolha da deusa. Em seguida, era iniciada a entrevista gravada. 
Ao finalizar os procedimentos da coleta dos dados, se reforçou à puérpera o sigilo mantido e foi pedido para que mantivesse, se possível, atualizados os dados de identificação, dentre eles, no mínimo o telefone para futuros contatos se necessário.

\section{Instrumento}

O instrumento de coleta de dados (APÊNDICE F) foi composto por três partes e suas questões foram formuladas a partir de resultados de estudos qualitativos realizados sobre o tema, no contexto sociocultural, no período puerperal (Pedroso, 1982; Costa, 2001; Stefanello, 2005; Castro et al., 2006; Luz, Berni, Selli, 2007; Silva, Roldán, 2009; Stefanello, Nakano, Gomes, 2008).

Compuseram o formulário:

Parte I - DADOS DE IDENTIFICAÇÃO: Com perguntas fechadas, que delinearam as características da mulher e envolveram os seguintes itens: idade, escolaridade, situação conjugal, acessibilidade para realização do pré-natal e consultas de pós-parto, renda familiar e per capita e dados sobre consulta de pré-natal e parto.

Parte II - DADOS SOBRE O PÓS-PARTO: Na qual foram abordadas questões que contextualizaram a puérpera junto aos familiares e cuidados pós-natal.

Parte III - Complementação da entrevista com a QUESTÃO ABERTA, disposta a seguir:

- "Me fale os cuidados que você está tendo com você após o nascimento do bebê."

TEMAS COMPLEMENTARES compuseram a última etapa da entrevista e somente foram abordados quando não citados pela puérpera durante resposta da pergunta aberta. Tratavam de higiene, alimentação e esforço/repouso.

\section{TRATAMENTO E ANÁLISE DOS DADOS}

Os dados obtidos com as questões da Parte I do instrumento de coleta de dados (APÊNDICE F) foram utilizados para caracterização da mulher de forma descritiva. 
Os dados advindos da pergunta norteadora foram tratados e apresentados segundo o Discurso do Sujeito Coletivo (DSC), proposto por Lefèvre, Lefèvre (2005), ao final dos anos 1990.

O DSC é uma "ferramenta" que trabalha dados qualitativos. Ao ser entrevistado, o participante narra, de modo empírico, seus pensamentos reais e objetivos, ligados ao consciente, e os subjetivos, ou seja, o inconsciente, no qual encontramos as crenças e os valores do indivíduo, assim como os sentimentos e os comportamentos (Lefèvere, Lefèvre, Teixeira, 2000).

Sendo assim, essa estratégia metodológica é formada por um conjunto de representações discursivas que fundamenta a representação social, ou seja, transmite, por meio dos discursos coletivos, os pensamentos de um grupo de indivíduos. Portanto, o grupo seria o autor responsável pelo discurso e é representado pelos relatos do conjunto de seus membros, explícitos individualmente. Dessa maneira, os aspectos culturais e sociais de um grupo são elencados por meio das estratificações pessoais (Lefèvere, Lefèvre, Teixeira, 2000; Lefèvere; Lefèvere, 2006).

A técnica do discurso do sujeito coletivo é construída com base na:

discursividade coletiva; sendo assim, os dados coletados, ao serem analisados não se restringem a uma determinada categoria, com isso, expressões e ideias centrais advindas dos discursos individuais são unidos por semelhança formando um discurso único com a finalidade de demonstrar um fenômeno (Lefèvere, Lefèvre, Teixeira, 2000, p.19)

Então, os indivíduos que compõem a Representação Social de uma determinada população são vistos como geradores de pensamentos coletivos, ao se utilizar o DSC, deixando de ser um indivíduo único e incorporando, através dos discursos, uma representação que expresse tanto a cultura como a sociedade à qual está inserido, o que colabora para evitar o reducionismo dos dados sociais a categorizações (Lefèvere, Lefèvre, Teixeira, 2000).

Os relatos das 20 puérperas atendidas em uma UBS no município de Rio Claro mostraram as práticas de cuidado no pós-parto.

As entrevistas gravadas tiveram seus conteúdos transcritos literalmente. Em seguida, estes foram lidos repetidas vezes para que fossem compreendidos.

Após essa sequência, foram extraídas as Expressões-chave, que são trechos e partes literais dos relatos que permitiram identificar partes dos conteúdos de interesse 
para o estudo. A partir das Expressões-chaves foram inferidas as Ideias Centrais (IC), que são afirmações que traduzem, de maneira objetiva, a essência das Expressõeschave identificadas (Lefèvere, Lefèvre, Teixeira, 2000).

Em seguida, as Ideias Centrais, com suas Expressões-chave correspondentes, foram categorizadas e agrupadas por similaridade temática, segundo os Domínios do Modelo de Competência Cultural de Purnell. O passo seguinte foi a construção de 21 Discursos do Sujeito Coletivo, estruturados com as Expressões-Chave que originaram cada Ideia Central que os compuseram.

Vale salientar que, mesmo sendo escrito na primeira pessoa do singular, cada DSC corresponde ao relato das 20 mulheres participantes do estudo, que representam as puérperas usuárias da UBS campo do estudo.

Dessa forma, a construção do DSC pode ser exemplificada como visto no Quadro 1, a seguir.

\begin{tabular}{|c|c|c|c|}
\hline 1 $^{\text {a ETAPA }}$ & $2^{\text {a }}$ ETAPA & $3^{\text {a ETAPA }}$ & $4^{\text {a }}$ ETAPA \\
\hline Discurso na íntegra & Expressões-chave & Ideias centrais & $\begin{array}{c}\text { Classificação segundo os } \\
\text { domínios do MCC de } \\
\text { Purnell }\end{array}$ \\
\hline $\begin{array}{l}\text { "Ah...que nem, no começo } \\
\text { que, ai, que tem um pouco de } \\
\text { medo e o....ah, eu não fazia o } \\
\text { serviço de casa, ficava } \\
\text { sempre em repouso; que nem } \\
\text { eu falo, tem que..por essa } \\
\text { idade ter sido uma } \\
\text { cirurgia...(hum rum- } \\
\text { pesquisadora)...até cicatrizar } \\
\text { o corte, eu não fazia o } \\
\text { serviço, não fazia nada, } \\
\text { ficava o máximo que eu } \\
\text { posso conseguir andar } \\
\text { melhor...(hum rum- } \\
\text { pesquisadora)... } \\
\text { ah, via, ah, tomava banho, } \\
\text { ah, lavava a cabeça normal, } \\
\text { não dava para ficar bom, ah o } \\
\text { que a minha sogra, o que o } \\
\text { pessoal falava, não dava } \\
\text { muita bola não. Ah, só } \\
\text { isso...”. }\end{array}$ & $\begin{array}{c}\text { Ah...que nem, no começo } \\
\text { que, ai, que tem um pouco de } \\
\text { medo e o...ah, eu não fazia o } \\
\text { serviço de casa, ficava } \\
\text { sempre em repouso; que nem } \\
\text { eu falo, tem que..por essa } \\
\text { idade ter sido uma } \\
\text { cirurgia...(hum rum- } \\
\text { pesquisadora)...até cicatrizar } \\
\text { o corte, eu não fazia o } \\
\underline{\text { serviço, não fazia nada, }} \\
\text { ficava o máximo que eu } \\
\text { posso conseguir andar } \\
\text { melhor...(hum rum- } \\
\text { pesquisadora)... } \\
\text { ah, via, ah, tomava banho, } \\
\text { ah, lavava a cabeça normal, } \\
\text { não dava para ficar bom, ah o } \\
\underline{\text { que a minha sogra, o que o }} \\
\text { pessoal falava, não dava } \\
\underline{\text { muita bola não. Ah, só isso. }}\end{array}$ & $\begin{array}{l}\text { fazendo o serviço de casa e } \\
\text { ficando sempre em repouso } \\
\text { não fazendo o serviço, não } \\
\text { fazendo nada, até cicatrizar } \\
\text { o corte...” } \\
\text { tomando banho, e lavando } \\
\text { a cabeça normalmente } \\
\text { não ligando para o que a } \\
\text { sogra e o pessoal falava }\end{array}$ & $\begin{array}{l}\text { Prática de cuidado à saúde } \\
\text { (Responsabilidade relativa à } \\
\text { saúde) } \\
\text { Crença no pós-parto }\end{array}$ \\
\hline $\begin{array}{c}\text { "Eu tive cuidado com a } \\
\text { alimentação, só. (Silêncio) E } \\
\text { com peso, por causa da } \\
\text { cesárea mesmo, porque se } \\
\text { fosse parto normal eu iria } \\
\text { fazer tudo que tinha } \\
\text { mesmo..." }\end{array}$ & $\begin{array}{c}\text { Eu tive cuidado com a } \\
\text { alimentação, só. (Silêncio) } \underline{E} \\
\underline{\text { com peso, por causa da }} \\
\underline{\text { cesárea mesmo, porque se }} \\
\underline{\text { fosse parto normal eu iria }} \\
\text { fazer tudo que tinha mesmo. }\end{array}$ & $\begin{array}{c}\text { tendo cuidado com a } \\
\text { alimentação } \\
\text { evitando peso, por causa da } \\
\text { cesárea }\end{array}$ & $\begin{array}{c}\text { Nutrição } \\
\text { (Alimentação) } \\
\text { Práticas de cuidado à saúde } \\
\text { (Responsabilidade relativa à } \\
\text { saúde) }\end{array}$ \\
\hline
\end{tabular}

QUADRO 1 - O passo a passo da construção do DSC. São Paulo, 2012. 
Ressaltamos que cada DSC foi identificado por um título, que representa seu conteúdo, e está disposto conforme cada domínio do Modelo de Competência Cultural de Purnell, referencial teórico deste estudo, cujos princípios direcionaram a análise dos dados obtidos.

\section{PRÉ-TESTE}

Foi realizado pré-teste com o intuito de avaliar a compreensão das mulheres sobre as questões que compõem o formulário (APÊNDICE F).

Como as três puérperas participantes do pré-teste compreenderam as questões do instrumento (APÊNDICE F), elas foram incluídas como participantes do estudo. Vale salientar que o pré-teste foi iniciado após aprovação do projeto pelo Comitê de Ética em Pesquisa e pela Secretaria de Saúde de Rio Claro.

\section{PRINCÍPIOS ÉTICOS}

Este estudo obteve aprovação do Comitê de Ética em Pesquisa (CEP) da Escola de Enfermagem da Universidade de São Paulo, processo no 989/2010 (APÊNDICE G).

Com a aprovação pelo CEP, o passo seguinte foi o encaminhamento da carta de solicitação de Autorização de Pesquisa, à Secretaria Municipal de Saúde de Rio Claro. O secretário de saúde do município autorizou e liberou o campo de coleta, com a concordância do médico responsável pelo setor de Atenção Básica do município (APÊNDICE B).

As mulheres que aceitaram participar da pesquisa assinaram o Termo de Consentimento Livre e Esclarecido (TCLE) (APÊNDICE H), confeccionado em duas vias, segundo as normas da Resolução 196/96, do Conselho Nacional de Saúde.

O TCLE era lido pela pesquisadora para a puérpera antes do início da coleta de dados e, caso houvesse alguma dúvida, essa era sanada para posterior assinatura do termo.

A seguir, apresentamos os resultados obtidos com as entrevistas das 20 participantes do estudo. 


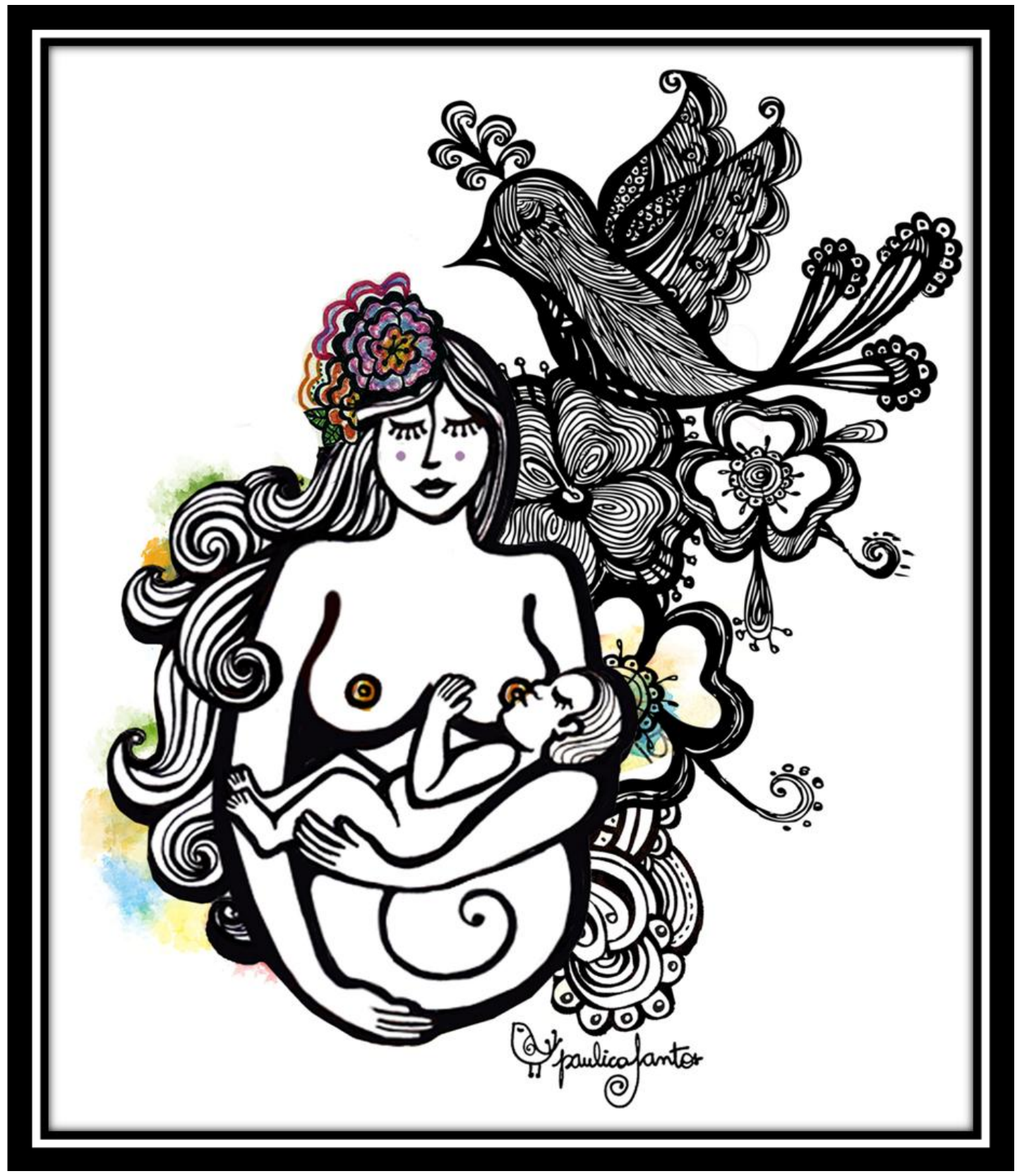

Fonte: http://paulicasantos.wordpress.com/

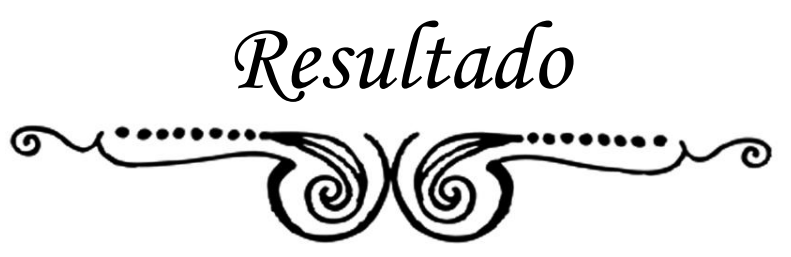




\section{Caracterização das participantes}

As puérperas participantes do presente estudo foram caracterizadas por meio dos dados de identificação (PARTE I - APÊNDICE F), coletados na entrevista. Foram identificadas pelas iniciais de seus nomes e reconhecidas por deusas. Esse reconhecimento como deusa foi utilizado como meio de manter o anonimato da participante, além de demonstrar sua identificação pessoal com a deusa de sua escolha.

A seguir, apresentamos os quadros com os dados de identificação de cada puérpera, segundo a ordem e a data das entrevistas. 


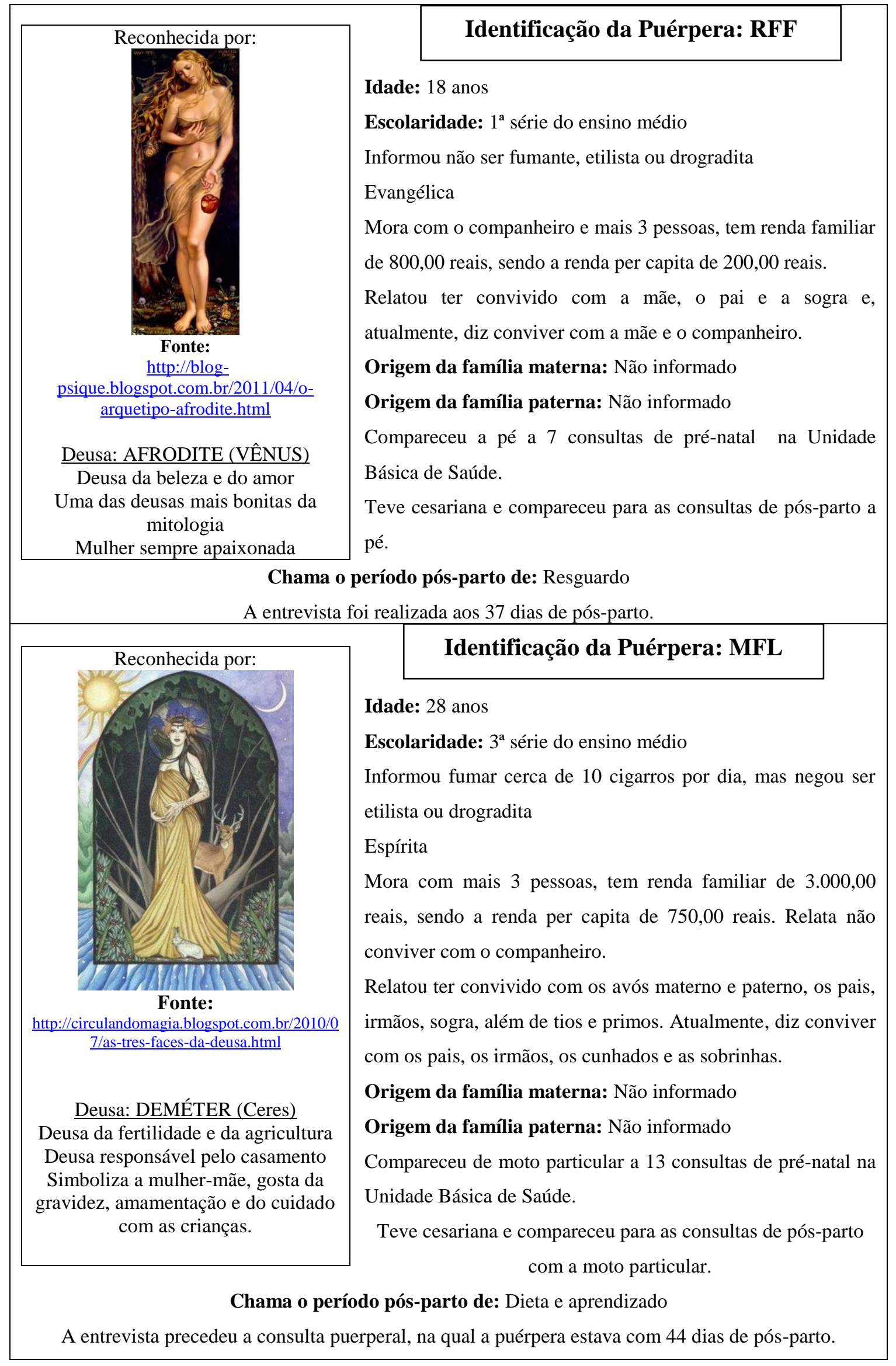




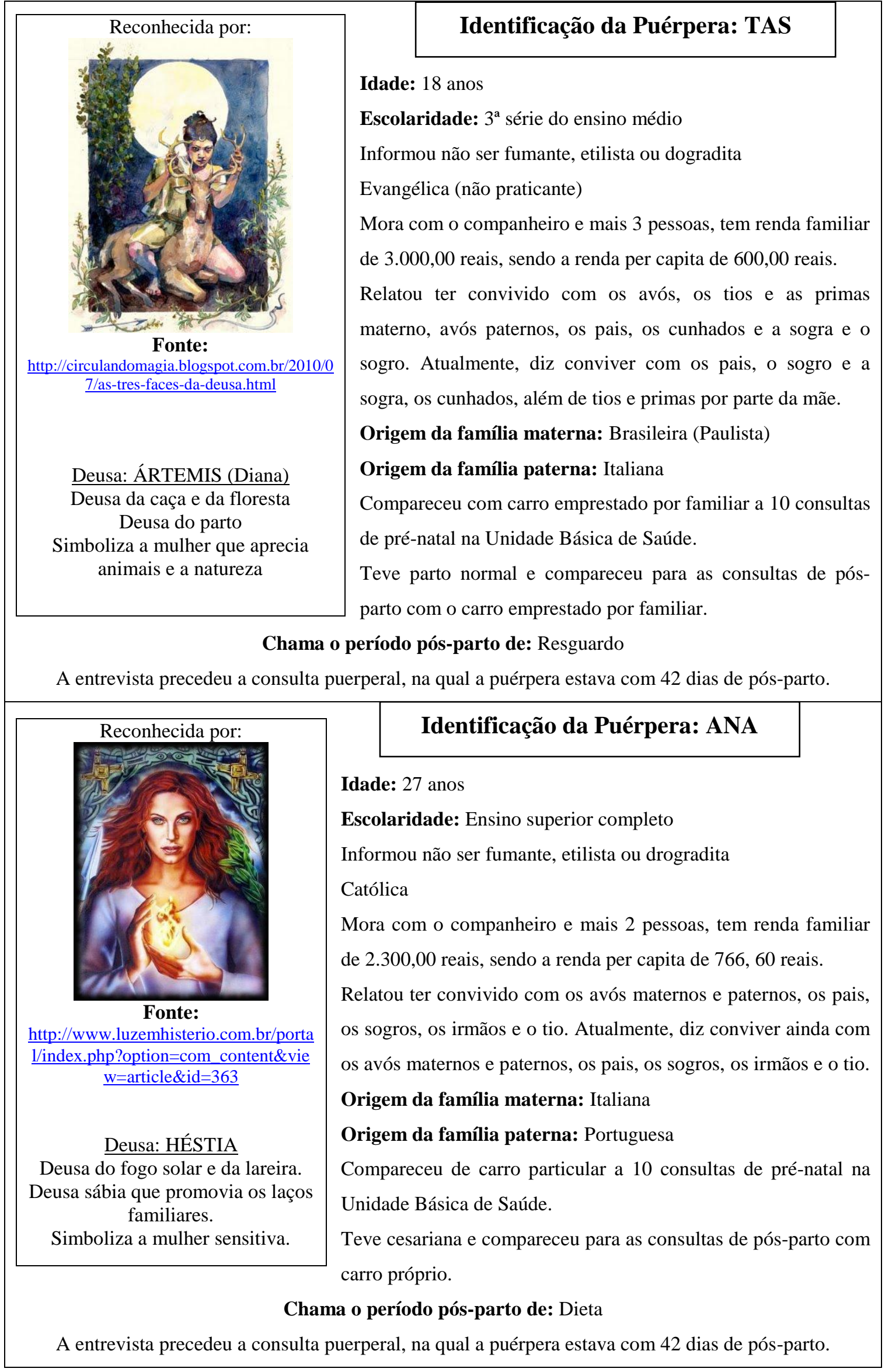




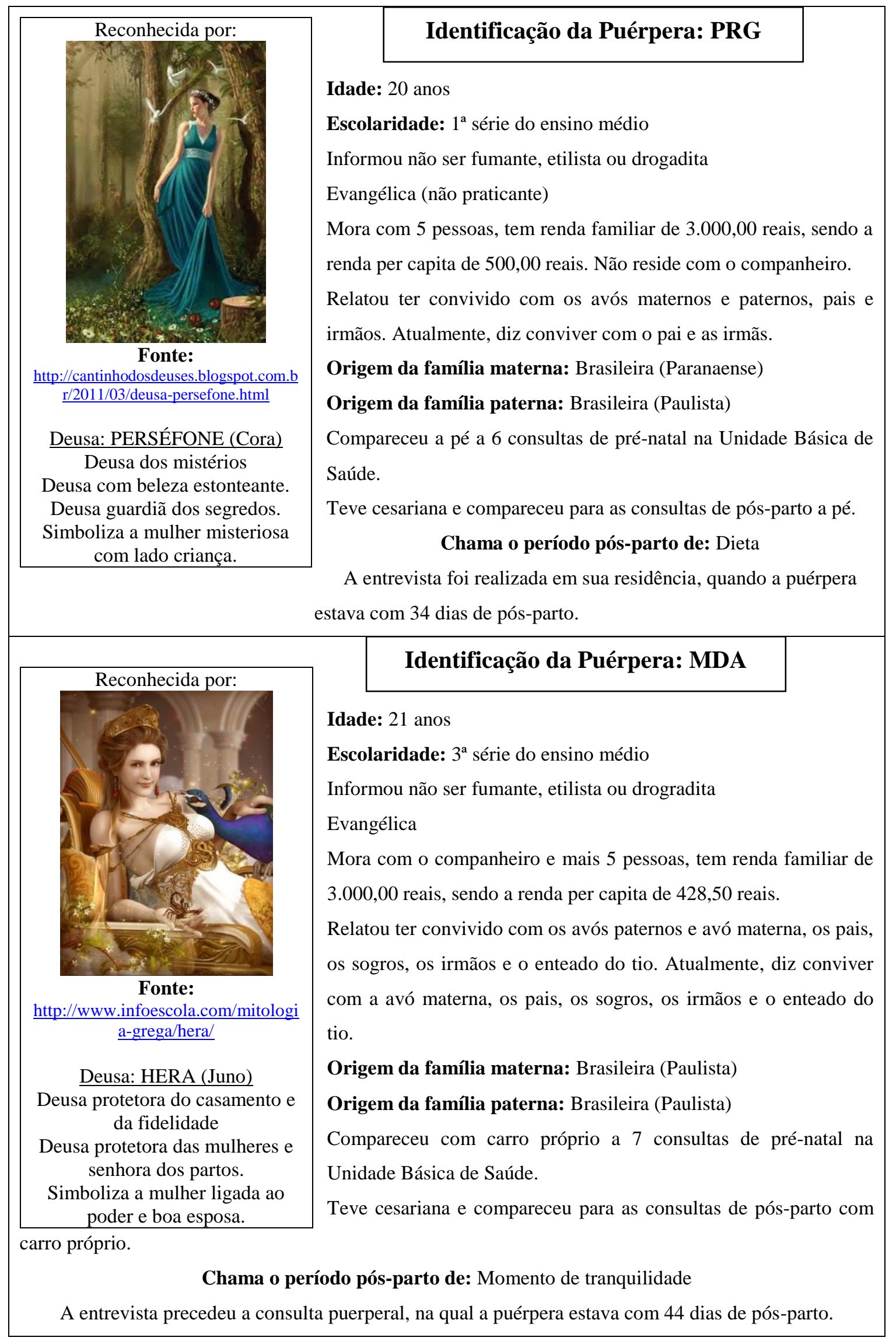




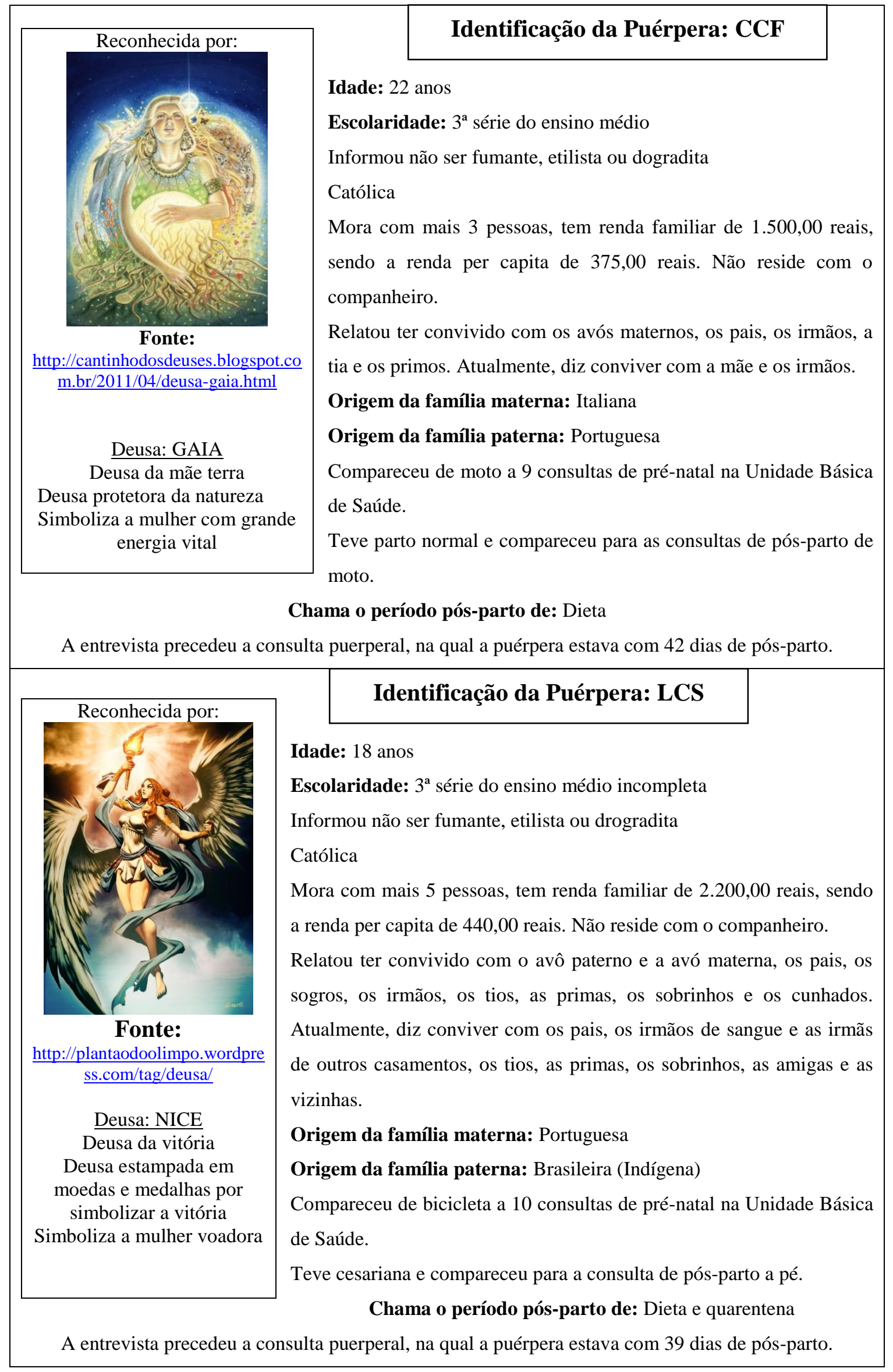




\begin{tabular}{|c|c|c|}
\hline Reconhed & \multicolumn{2}{|l|}{ Identificação da Puérpera: ANAC } \\
\hline $\begin{array}{l}\text { Deusa: ATENA } \\
\text { Deusa da guerra, da sabedoria } \\
\text { e das artes. } \\
\text { Deusa prudente e estrategista. } \\
\begin{array}{c}\text { Simboliza a mulher guerreira e } \\
\text { intelectual. }\end{array}\end{array}$ & \multicolumn{2}{|c|}{$\begin{array}{l}\text { Idade: } 22 \text { anos } \\
\text { Escolaridade: Ensino superior incompleto } \\
\text { Informou não ser fumante e etilista, mas já fez uso de maconha antes } \\
\text { da gestação. } \\
\text { Agnóstica } \\
\text { Mora com o companheiro e mais } 5 \text { pessoas, tem renda familiar de } \\
4.000,00 \text { reais, sendo a renda per capita de } 666,60 \text { reais. } \\
\text { Relatou ter convivido com a avó materna, a mãe, os irmãos e o } \\
\text { padrasto. Atualmente, diz conviver com a mãe, os sogros, os irmãos } \\
\text { e o padrasto. } \\
\text { Origem da família materna: Portuguesa } \\
\text { Origem da família paterna: Espanhola } \\
\text { Compareceu a pé a } 7 \text { consultas de pré-natal na Unidade Básica de } \\
\text { Saúde. } \\
\text { Teve cesariana e compareceu para as consultas de pós-parto de carro } \\
\text { próprio. }\end{array}$} \\
\hline \multicolumn{3}{|c|}{$\begin{array}{l}\text { A entrevista foi realizada no local do serviço da mesma, na qual a puérpera estava com } 41 \text { dias de pós- } \\
\text { parto. }\end{array}$} \\
\hline & Identificação da Puérpera: JABF & \\
\hline $\begin{array}{l}\text { Deusa: HEBE } \\
\text { Deusa da juventude } \\
\text { Deusa do perdão. } \\
\text { Simboliza a mulher jovial e } \\
\text { que gosta de casar jovem. }\end{array}$ & $\begin{array}{l}\text { Idade: } 20 \text { anos } \\
\text { Escolaridade: } 3^{a} \text { série do ensino médio incompleta } \\
\text { Informou não ser fumante, etilista ou drogradita } \\
\text { Católica } \\
\text { Mora com o companheiro e mais } 4 \text { pessoas, tem } \\
2.700,00 \text { reais, sendo a renda per capita de } 540,00 \text { rea } \\
\text { Relatou ter convivido com a avó paterna, a mãe } \\
\text { sobrinhas da mãe. Atualmente, diz conviver com a n } \\
\text { marido. } \\
\text { Origem da família materna: Brasileira (Indígena) } \\
\text { Origem da família paterna: Italiana } \\
\text { Compareceu de carro familiar próprio a } 10 \text { consult } \\
\text { Unidade Básica de Saúde. }\end{array}$ & $\begin{array}{l}\text { da familiar de } \\
\text {, os irmãos e as } \\
\text { de pré-natal na }\end{array}$ \\
\hline Teve cesariana e compareceu pa & $\begin{array}{l}\text { a as consultas de carro familiar próprio. } \\
\text { Chama o período pós-parto de: Dieta }\end{array}$ & \\
\hline
\end{tabular}




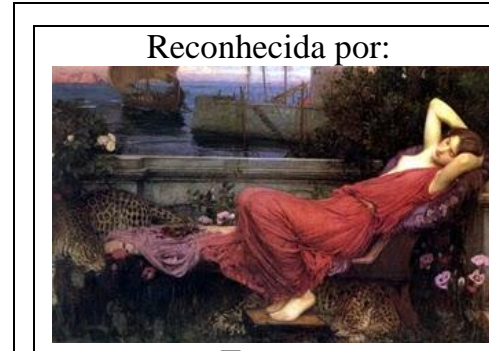

Fonte:

http://www.tradicaoathenapronaia .com/2011/09/ariadne-edionisio.html

\section{Deusa: ARIADNE}

Deusa do êxtase

Deusa heroína e sagrada

Simboliza a mulher que busca o autoconhecimento.

\section{Identificação da Puérpera: ATP}

Idade: 24 anos

Escolaridade: $3^{\text {a }}$ série do ensino médio

Informou não ser fumante, etilista ou drogradita

Católica

Mora com o companheiro e mais 1 pessoa e não soube informar a renda familiar bruta por não estar trabalhando.

Relatou ter convivido com os avós maternos, o irmão, a prima e tia materna, a mãe e os sogros. Atualmente, diz conviver com os sogros e o companheiro.

Origem da família materna: Brasileira (Bahiana)

Origem da família paterna: Japonesa

Compareceu a pé a 10 consultas de pré-natal na Unidade Básica de Saúde.

Teve parto normal e compareceu para as consultas de pós-parto a pé.

Chama o período pós-parto de: Dieta

A entrevista precedeu a consulta puerperal, na qual a puérpera estava com 41 dias de pós-parto.

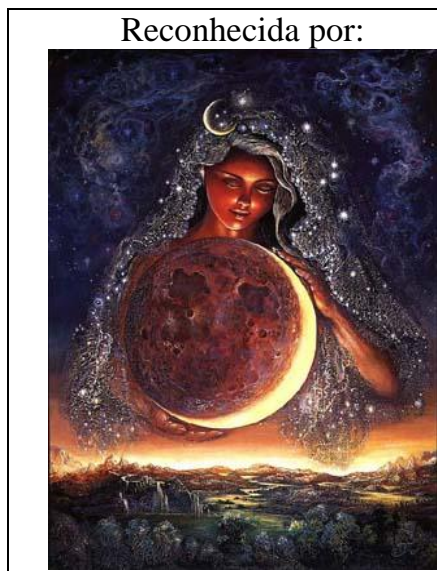

Fonte:

http://aprendendohistoriajuntos.bl ogspot.com.br/2012/02/07-defevereiro-dia-de-selene-deusada.html

\section{Deusa: SELENE}

Deusa da lua

Deusa ligada à luz e à

fertilidade da natureza

Simboliza a mulher mística e sacertodisa

\section{Identificação da Puérpera: BCN}

Idade: 18 anos

Escolaridade: $3^{\text {a }}$ série do ensino médio

Informou não ser fumante, etilista ou drogradita

Testemunha de Jeová

Mora com o companheiro e mais 6 pessoas e não soube informar a renda familiar bruta ou aproximada, uma vez que não está trabalhando.

Relatou ter convivido com os avós paternos, os pais, o irmão e os sogros. Atualmente, diz conviver com a com a avó paterna, os pais, a sogra e o sogro.

Origem da família materna: Brasileira (Paulista)

Origem da família paterna: Brasileira (Paulista)

Compareceu de carro familiar próprio a 5 consultas de pré-natal na Unidade Básica de Saúde.

Teve parto normal e compareceu para as consultas de carro familiar próprio.

Chama o período pós-parto de: Dieta e Resguardo

A entrevista precedeu a consulta puerperal, na qual a puérpera estava com 36 dias de pós-parto. 


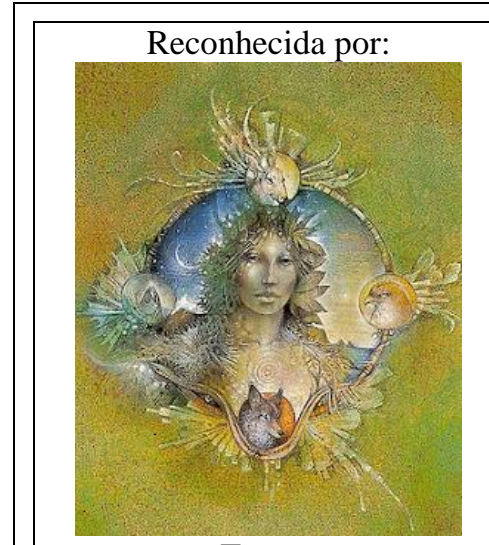

Fonte:

http://renascer-adeusa.blogspot.com.br/2008/01/ev a-deusa.html

Deusa: EVA

Deusa da vida

Deusa ligada à manutenção da vida.

Simboliza a mulher com grande energia vital.

\section{Identificação da Puérpera: MRLG}

Idade: 30 anos

Escolaridade: $3^{\text {a }}$ série do ensino médio

Informou não ser fumante, etilista ou drogradita

Católica

Mora com o companheiro e mais 3 pessoas, tem renda familiar de $1.600,00$ reais, sendo a renda per capita de 400,00 reais.

Relatou ter convivido com os pais, a irmã, os sogros, os primos e as tias maternas e paternas. Atualmente, diz conviver com a sogra, o irmão, as tias e as primas maternas e paternas.

Origem da família materna: Brasileira (Pernambucana)

Origem da família paterna: Brasileira (Pernambucana)

Compareceu de carro familiar próprio a 8 consultas de pré-natal na Unidade Básica de Saúde.

Teve parto normal e compareceu para as consultas de pós-parto de ônibus.

Chama o período pós-parto de: Resguardo

A entrevista precedeu a consulta puerperal, na qual a puérpera estava com 39 dias de pós-parto.

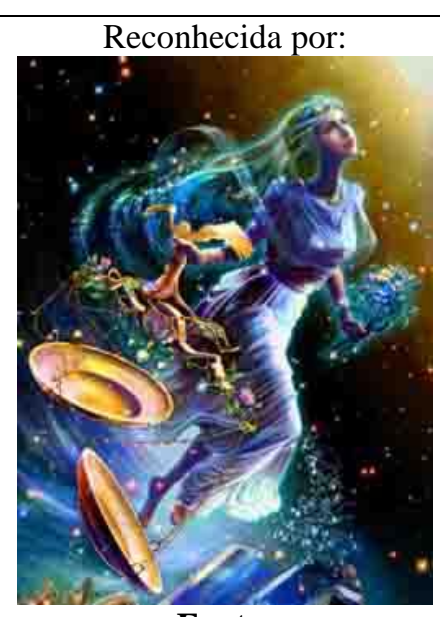

Fonte:

http://deuseseherois.webnode.com .br/products/t\%C3\%AAmis/

Deusa: TÊMIS

Deusa da justiça

Deusa das leis e que protege os oprimidos.

Simboliza a mulher que busca o equilíbrio interno.

\section{Identificação da Puérpera: AL}

Idade: 32 anos

Escolaridade: $3^{\mathrm{a}}$ série do ensino médio

Informou não ser fumante, etilista ou drogradita

Católica

Mora com o companheiro e mais 2 pessoas, tem renda familiar de $1.300,00$ reais, sendo a renda per capita de 433,30 reais.

Relatou ter convivido com a mãe, o irmão, os sogros e a tia materna. Atualmente, diz conviver com o companheiro, o irmão, a cunhada e a mãe da cunhada.

Origem da família materna: Brasileira (Bahiana)

Origem da família paterna: Brasileira (Bahiana)

Compareceu de carona a 12 consultas de pré-natal na Unidade Básica de Saúde.

Teve cesariana e compareceu para as consultas de pós-parto de carona.

Chama o período pós-parto de: Dieta e Resguardo

A entrevista precedeu a consulta puerperal, na qual a puérpera estava com 45 dias de pós-parto. 


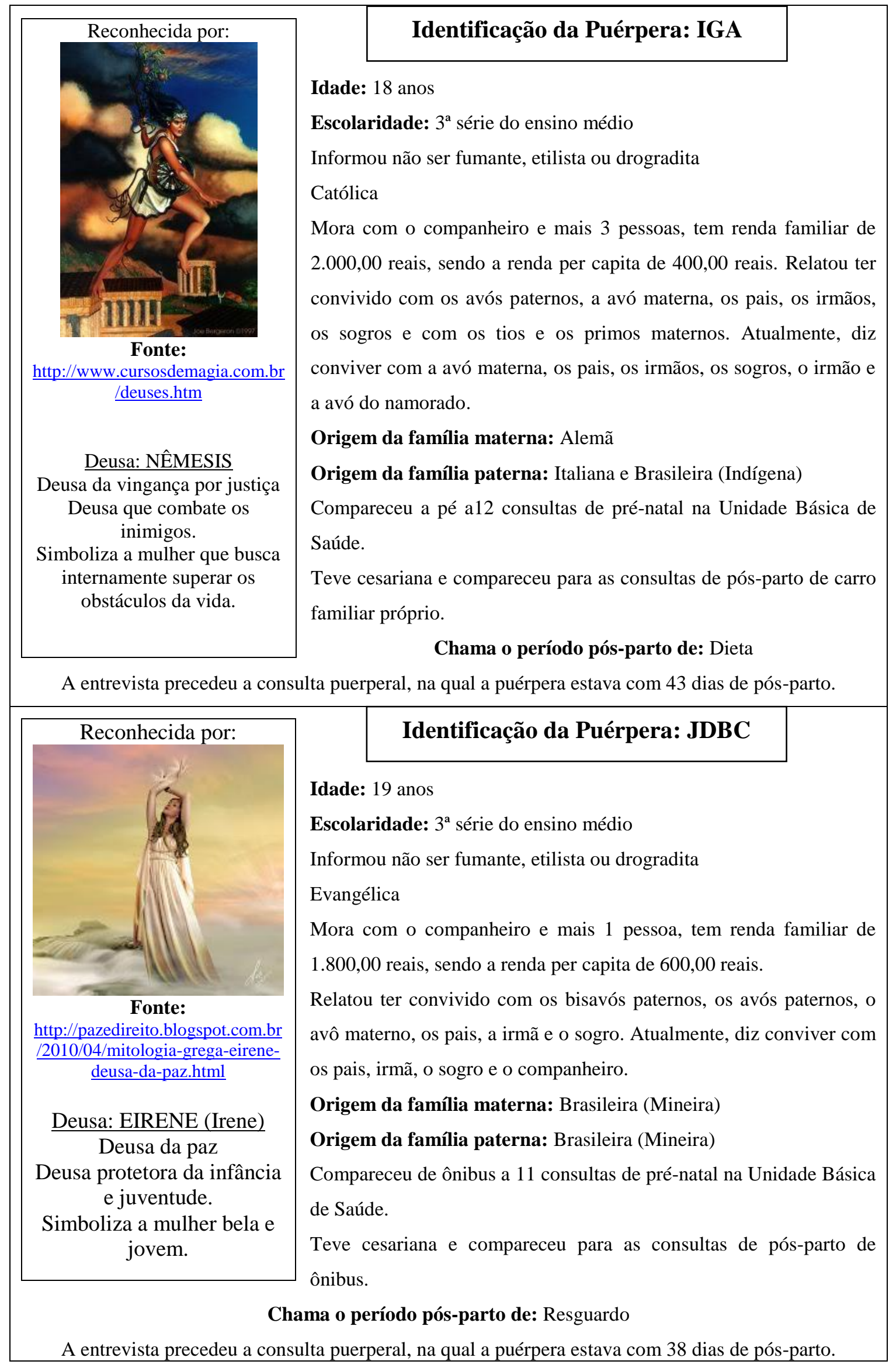




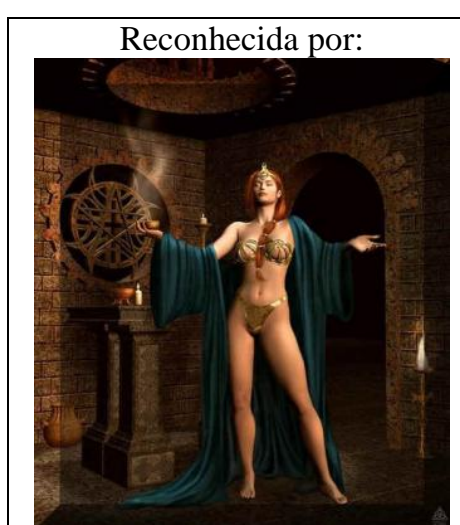

Fonte:

http://www.cursosdemagia.com.b r/deuses.htm

Deusa: ÍRIS

Deusa mensageira

Deusa responsável por unir o céu e a terra.

Simboliza a mulher que busca liberdade e leveza.

\section{Identificação da Puérpera: DFZ}

Idade: 21 anos

Escolaridade: $3^{\mathrm{a}}$ série do ensino médio

Informou não ser fumante, etilista ou drogradita

Agnóstica

Mora com mais 5 pessoas, tem renda familiar de 2.000,00 reais, sendo a renda per capita de 333,30 reais. Não reside com o companheiro.

Relatou ter convivido com os pais e as irmãs. Atualmente, diz conviver com a mãe e as irmãs e não tem companheiro.

Origem da família materna: Brasileira (Paulista)

Origem da família paterna: Italiana e Alemã

Compareceu de carro familiar próprio a 9 consultas de pré-natal na Unidade Básica de Saúde.

Teve cesariana e compareceu para as consultas de pós-parto com carro familiar próprio.

\section{Chama o período pós-parto de: Dieta}

A entrevista precedeu a consulta puerperal, na qual a puérpera estava com 42 dias de pós-parto.

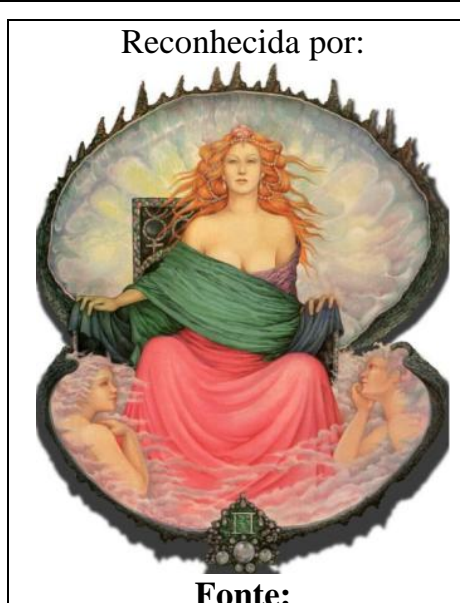

http://gladio.blogspot.com.br/201 0/12/salacia-deusa-padroeira-dealcacer-do.html

Deusa: ANFITRITE (Salácia)

Deusa do mar

Deusa ligada às águas salgadas.

Simboliza a mulher agitada e inquieta.

\section{Identificação da Puérpera: KMV}

Idade: 21 anos

Escolaridade: $3^{\mathrm{a}}$ série do ensino médio

Informou não ser fumante, mas já fez uso de cocaína e tem hábito de ingerir bebida alcoólica, ao menos uma vez na semana.

Evangélica

Mora com o companheiro e mais 4 pessoas, tem renda familiar de 870,00 reais, sendo a renda per capita de 145,00 reais.

Relatou ter convivido com as avós materna e paterna, os pais, os sogros, os irmãos, além de tios e primos maternos e paternos. Atualmente, diz conviver com os pais, os sogros, os irmãos e o companheiro.

Origem da família materna: Brasileira ( Indígena e Bahiana)

Origem da família paterna: Brasileira (Mineira)

Compareceu de moto a 3 consultas de pré-natal na Unidade Básica de Saúde.

Teve cesariana e compareceu para as consultas de pós-parto de moto.

Chama o período pós-parto de: Resguardo

A entrevista precedeu a consulta puerperal, na qual a puérpera estava com 42 dias de pós-parto. 


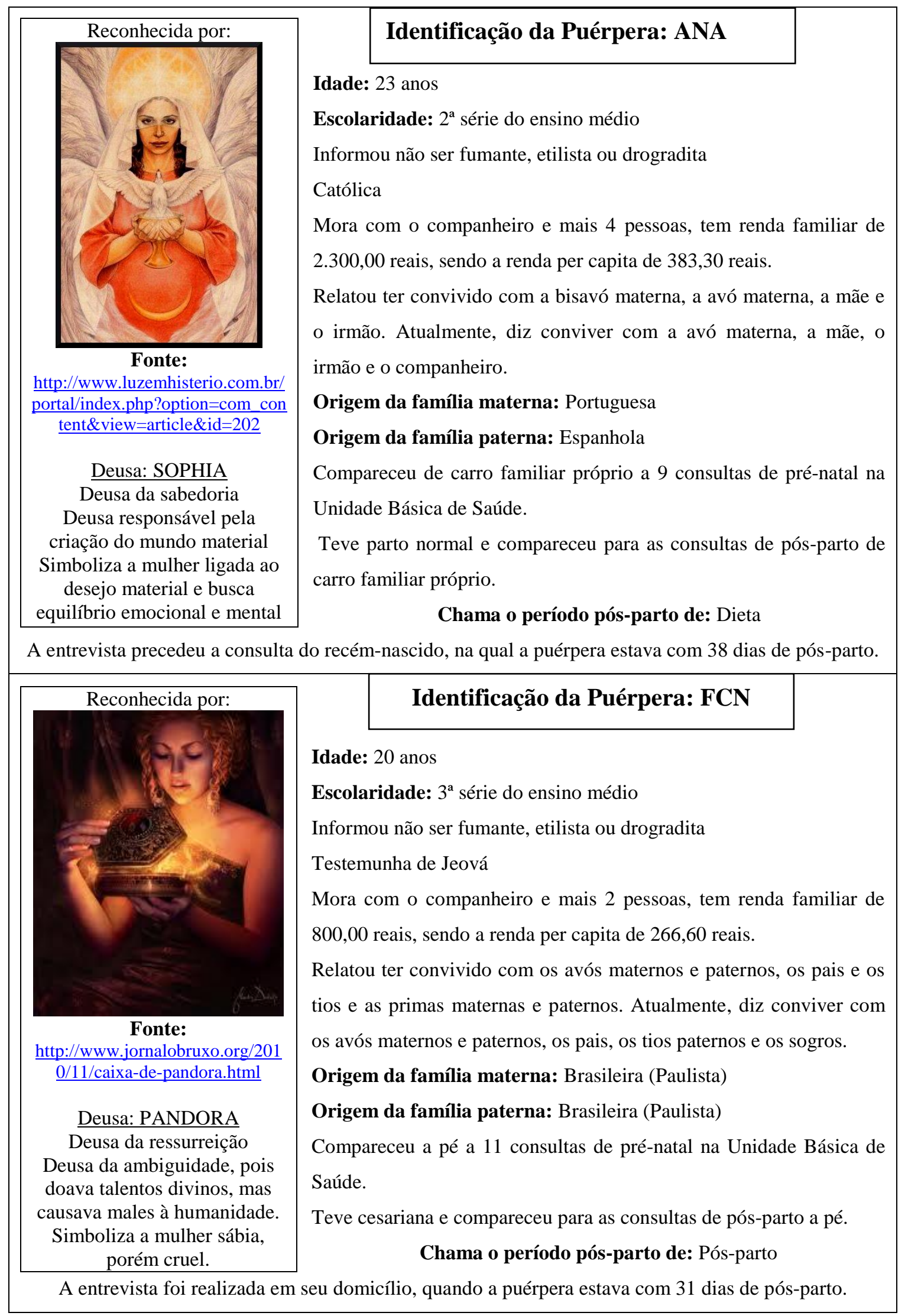


O APÊNDICE H mostra a síntese dos dados sociodemográficos das puérperas entrevistadas.

Notamos, pela identificação das puérperas, que estas se encontravam entre o $31^{\circ}$ e o $45^{\circ}$ dias de pós-parto, com a média de 40 dias entre o parto e a realização da entrevista. A média de duração das entrevistas foi de 21 minutos, sendo o tempo máximo aproximado de 59 minutos e de 7 minutos para a duração mínima.

Vimos que as puérperas tinham entre 18 e 32 anos de idade, com média de 22 anos e mediana de 21 anos. Quanto aos hábitos e vícios maternos, encontramos 1 puérpera que fumava, seguida de 1 que alegou ter usado maconha uma vez na vida e 1 que foi usuária de cocaína e referiu ingerir bebida alcoólica ao menos 1 vez na semana; 17 puérperas negaram fazer uso de bebida alcoólica, tabaco ou drogas ilícitas.

Quanto à escolaridade, entre as 20 puérperas, 15 tinham concluído o ensino médio, enquanto 3 não concluíram; 2 mulheres tinham cursado ensino superior, sendo que apenas uma o concluiu.

Frente aos dados socioeconômicos, verificamos que a maior renda familiar foi de 4.000 reais e a menor de 800 reais, com média mensal das rendas das famílias de $2.120,55$ reais. A menor renda per capita encontrada foi de 145,00 reais, sendo a maior de 766,00 reais. Cabe salientar, que 2 puérperas não souberam informar a renda familiar aproximada, pois não trabalhavam e não tinham contato com os gastos da família.

Os dados mostram, também, que o máximo de pessoas que residia na mesma casa era de 7 indivíduos, com o mínimo de 3, contando com o recém-nascido. A média e a mediana de membros por família foram de 5 indivíduos, incluindo o recém-nascido.

Dentre os meios de transporte utilizados para acesso à UBS para se submeter a consultas de pré-natal e ao retorno puerperal, destacamos: o carro próprio, o carro familiar próprio e, em alguns casos, encontramos a carona. Além desses meios, ainda verificamos o uso de motocicleta, bicicleta, ônibus e caminhada dentre as que residiam ou trabalhavam próximo à UBS. Podemos verificar, ainda, que os meios de transporte se modificaram, em alguns casos, entre o período de gravidez e após o nascimento do recém-nascido. 
Podemos encontrar que apenas 2 puérperas eram agnósticas, mas, dentre as demais entrevistadas, os dados mostram as seguintes práticas religiosas: evangélica, católica, testemunha de Jeová e espírita. Algumas mulheres mencionaram ter religião, mas não eram praticantes.

Frente aos dados do ciclo gravídico-puerperal, podemos verificar que o número de consultas de pré-natal variou entre 3 e 13. Vale salientar que este foi fornecido pela puérpera e que no momento da entrevista não tínhamos contato com o cartão de pré-natal para confrontar a informação. A média de consultas referidas por puérpera foi de 9 ao longo da gravidez. Outro dado que pode ser verificado é a via de parto de cada puérpera: houve 6 partos normais e 14 cesáreas. Cabe esclarecer que não foram estudadas as causas que levaram às cesáreas, nem foi avaliado o emprego de fórceps e de episiotomia, dentre outras práticas obstétricas.

Ao se perguntar sobre o nome que dão ao período pós-parto, as puérperas citaram os seguintes: resguardo, dieta, quarentena, pós-parto, momento de tranquilidade e aprendizado.

Após a apresentação dos dados de caracterização das puérperas, trazemos, a seguir, os Discursos do Sujeito Coletivo construídos a partir de seus relatos e segundo o método de Lefèvre, Lefèvre (2005). 


\section{Os discursos do sujeito coletivo}

No quadro abaixo, trazemos os DSC construídos e inseridos em seus respectivos domínios.

QUADRO 2 - Relação dos DSC e sua inserção nos domínios do Modelo de Competência Cultural de Purnell. São Paulo, 2012.

\begin{tabular}{|c|c|}
\hline $\begin{array}{l}\text { Domínios do MCC de } \\
\text { Purnell }\end{array}$ & DSC \\
\hline Nutrição & $\begin{array}{c}\text { A preocupação com a alimentação após o } \\
\text { nascimento do bebê } \\
\text { A escolha alimentar da puérpera }\end{array}$ \\
\hline $\begin{array}{l}\text { Práticas na gravidez, } \\
\text { parto e puerpério }\end{array}$ & $\begin{array}{c}\text { Resguardando-se: Os cuidados no período do pós-parto } \\
\text { Cuidados no pós-parto: Evitando carregar peso e } \\
\text { esforçar-se! } \\
\text { O autocuidado para a higiene... } \\
\text {...da cabeça } \\
\text {...da incisão } \\
\text { A friagem: Um perigo que ronda o pós-parto } \\
\text { Deixando a beleza meio de lado... } \\
\text { Vestindo-se no pós-parto e cuidados com a estética } \\
\text { Descobrindo a "mãe do corpo" } \\
\text { Sexo: nem pensar!! } \\
\text { Amamentação: das crenças às novas formas de cuidado } \\
\text { Sentindo-se pressionada: a transição da mulher para ser } \\
\text { mãe } \\
\text { Crenças e cuidados do recém-nascido }\end{array}$ \\
\hline Espiritualidade & Mantendo a religiosidade \\
\hline $\begin{array}{l}\text { Práticas de cuidado à } \\
\text { saúde }\end{array}$ & $\begin{array}{l}\text { Mudanças de hábitos no pós-parto: Tornando-se mais } \\
\text { responsável } \\
\text { Aprendendo com a vida e se atualizando com as redes } \\
\text { sociais } \\
\text { Acreditando no benzimento }\end{array}$ \\
\hline $\begin{array}{l}\text { Provedor de cuidado à } \\
\text { saúde }\end{array}$ & $\begin{array}{l}\text { As opções de cuidado no pós-parto: Seguindo as } \\
\text { orientações de vários provedores } \\
\text { Cuidados pautados nas orientações dos provedores da } \\
\text { saúde } \\
\text { O cuidado determinado pelos cuidadores culturais }\end{array}$ \\
\hline Destoante & $\begin{array}{l}\text { Rompendo com os paradigmas sobre as práticas de } \\
\text { cuidado no pós-parto }\end{array}$ \\
\hline
\end{tabular}




\section{Domínio: NUTRIÇÃO}

\section{DSC: A preocupação com a alimentação após o nascimento do bebê}

Eu tenho uma boa alimentação. Estou comendo mais também, mas eu tive cuidado com a alimentação: procurei prestar mais atenção, tentar me alimentar bem. No comecinho quando eu cheguei, minha prima fez sopa pra mim com bastantes legumes. Me deram todos os tipos de fruta, mas parece que o tomate é um pouco ácido, e alface, falaram que eu não posso comer, mas tô comendo pouco, agora já tá voltando ao normal. A couve, eu sabia que tinha muito ferro e eu precisava porque eu tenho anemia. Eu tinha que repor as vitaminas no meu corpo comendo bastante arroz, feijão, lentilha, carne de panela cozida, bem cozida, pra ter bastante ferro e vitaminas diferentes. Agora, eu vou começar a tomar laranja com beterraba, que falam que reforça pra não dar anemia nele (bebê) por causa do sangue. Banana e morango eu comi bastante também porque falavam que era bom pra não dar anemia nele. A banana porque é forte e ajuda a fortalecer imunidade, já o morango é pra não dar anemia e a couve para o intestino, que faz bem pro nenê e ajuda a soltar o intestino, então, quase todo dia ela (sogra) faz couve refogada. Se ele está com o intestino solto eu como uma fruta ou algum alimento natural pra influenciar no leite e ajudar ele (bebê). Se ele (RN) fica com o intestino preso, eu acabo comendo mamão porque eu sei que influencia bastante na amamentação. Então, geralmente, eu tinha que comer maçã porque mamão solta muito o intestino, então, a maçã prende. Comia um, tinha que comer o outro. Ainda falavam que como o corpo não voltou ainda, a maçã resseca e pode ter dificuldade pra ir ao banheiro e estoura os pontos, então, comer mais aveia, essas coisas pra o funcionamento do intestino. Eu aumentei um pouquinho (a ingesta calórica) na semana por causa do leite. Além disso, eu procurei sempre comer coisas certas por causa do leite e para não ficar com o leite fraco. Na verdade, tomar leite era pra engrossar o leite (materno), pra dar mais leite pro nenê. Tinha que comer bastante fruta e tomar bastante suco de fruta, tanto que minha sogra falava bastante sobre comer e beber super bem suco pra produzir leite. Às vezes aumentei um pouco o arroz por causa do leite, no começo não deu muito leite! Além disso, eu tomava (chá) e dava para ele também, o chá de camomila, que falaram que ajuda acalmar, o chá de hortelã, no começo, por 
causa do nenê e das cólicas nele, mas eu só tomei uns 3 dias. Eu tirei uns (alimentos) por causa da cicatrização e uns pra não dar cólica nele (bebê), que nem o hambúrguer, eu parei, mas por causa do corte, não do bebê.

\section{DSC: A escolha alimentar da puérpera}

Quanto à minha alimentação, eu cortei bastante refrigerante. Não tomava refrigerante por causa dos gases, não tomava de jeito nenhum, não comia nem carne de porco, que é coisa que inflama (os pontos). Então, quanto à alimentação eu cortei essas coisas que falam que causa dores ou cólica nele (bebê). Então, eu não bebi refrigerante, nem comi doce ou chocolate. Também não me alimentei com nada de molho porque dá cólica no nenê por ser forte e deveria tomar muita água. Cortaram também café e nescau. Na verdade, não podia ficar tomando guaraná por causa do gás por conta dele (bebê) e não por minha causa. Eu não comia coisas com pimenta, coisas ácidas e carne forte como a carne de porco. No começo, ninguém me deixava comer peixe e fritura por causa da gordura. Então, se eu comesse (carne de porco) iria pro leite e daria cólica nele. A carne de porco por si só é muito gordurosa, portanto, parei de comer comida muito gordurosa pra melhor cicatrização dos pontos, por isso estou evitando bastante carne de porco, ovo, lingüiça e bacon. A carne de porco eu não comi até os pontos caírem. Além disso, presunto ela (mãe) não me deixa comer por causa dos pontos, por ser forte, na verdade, tudo que é forte ela não tá deixando comer devido aos pontos. Além disso, ela (mãe) ainda cortou os doces, o paio e até o tomate. Eu também não comia lasanha por causa do queijo e do presunto, nem macarrão porque tinha molho. Ela (sogra) fazia angu com molho e eu não comia porque tinha molho e não podia comer tomate porque era ácido, por isso, molho vermelho eu não comi. Meu pai também falou pra eu comer pouca (carne de porco e peixe) porque é muito forte e o corte podia não cicatrizar, então, nada de carne de porco, pimenta do reino, nada de pimenta, assim como coisas que poderiam inflamar. Então, eu preferi comer coisa mais saudável, porque carne de porco não é tão limpa. O ovo, falaram que não era pra eu comer, assim como o repolho, a manga, a laranja, o morango e o tomate. Então, também não podia comer muita fritura, pois era mais o perigo de inflamar (os pontos), sendo assim, só voltei a comer ovo e carne (de porco) depois do tempo da cicatrização, porque a carne de 
porco e o ovo têm muito óleo. Também (tirei alimentos) ácidos para não dar cólica no bebê e problema no leite; (o abacaxi) iria demorar mais pra cicatrizar os pontos. Fruta não podia comer muito por causa do bebê e do leite. Até achei estranho porque tem bastante fruta que é ácida, mas na maternidade falaram que era normal, tanto que quando eu estava internada eles deram suco de abacaxi natural e disseram que o suco não interferia, mas eu acho que é por causa da água, pois isso deixava mais fraco (o suco). Às vezes ainda tomo suco, mas eu tomo mais água agora do que o suco, suco só de maracujá quando tomo, e não tô tomando suco nem de caixinha e nem de saquinho: estou um pouco mais natural. Mesmo assim, tinha a preocupação com as frutas cítricas, como o limão, a laranja e o abacaxi que falaram que eu não podia. O que ela (mãe) falava que é ácido, eu evitei, pois eu não sabia até que ponto era saudável ou não! Todos só falavam que era pesado e pra mim não comer nem laranja, nem tomate e nem abacaxi porque era ácido e por conta da cicatrização. Eu adoro queijo, mas foram dois os motivos para minha preocupação: primeiro os gases e segundo a produção de leite. Ela (mãe) também não me deixa nem comer banana e tudo por causa do nenê porque é muito forte pra ele. Tanto que a mudança na alimentação tinha que durar três meses por causa do nenê e também pela recuperação dos pontos. As pessoas falam tanto da alimentação da mãe que por causa do leite não pode ser normal, e foi aí que eu tive o cuidado de pesquisar para saber o que eu podia comer ou não. Daí encontrei que era bom evitar feijão, couveflor, repolho, coisas que causam gases normalmente, mas também fiquei um tempo evitando isso e mais o queijo; além disso, tudo que tinha molho vermelho ou mesmo o branco, eu não comi por ser gorduroso. Eu gosto bastante que põe carne (na sopa) porque dá sabor, mas eles (familiares) não punham porque tinha muito ferro e, iria ficar no meu corpo, só que querendo ou não eu tinha anemia, eu tinha necessidade de comer essa coisas, mas não colocavam. Por isso, eu fui comendo coisa leve pra não inflamar (os pontos) tanto que eu estava comendo bastante sopa durante a noite pra não ficar pesado. Ainda falavam (familiares) que eu tinha que comer bastante vitamina, mas querendo ou não, sopa não tem tanta vitamina. Me fizeram comer muita couve porque falavam que era para ele (bebê) se acostumar com verdura diferente, mas salada de alface só podia comer com pouco tempero; feijão, até podia, mas só um pouquinho de caldo porque dá gases e passa para o bebê. Eu comi 
também pirão feito com galinha caipira, além de tomar água de canjica, milho e rapadura. Isso porque comer canjica era bom pro leite, além de ser uma comida forte. No começo, eu precisava tomar muito leite, leite com açúcar, mas foi quando o nenê começou a ter muita dor de barriga, eu mudei, passei a tomar leite de soja; a gente (entrevistada e sua mãe) achou mais apropriado beber a soja, por ser mais fraca porque o leite é forte. Porém se eu num puder tomar (leite), como vou produzir (leite)? E para tirar a grande vontade de tomar coca, eles (familiares) deixaram bem um restinho e chacoalharam até tirar o gás, daí eu bebi, mas carne de porco e coisa gordurosa eu não comi nada! Por fim, durante a dieta, cortei (alguns alimentos) pra não engordar muito e pra não dar cólica no bebê, mas depois que passou a dieta, que ele (bebê) parou de mamar, aí eu comecei a tomar e comer tudo normal; até voltei a tornar suco de abacaxi e comer feijão, mas tudo sem excesso.

\section{Domínio: PRÁTICAS NA GRAVIDEZ, PARTO E PUERPÉRIO}

\section{DSC: Resguardando-se: Os cuidados no período do pós-parto}

Eu consegui fazer 30 dias (de dieta) porque comecei a fazer as coisas com uns 20, 30 dias. Antes, eu morria de medo de fazer as coisas e estourar os pontos e ter que passar por tudo aquilo novamente, nossa morria de medo! Era pra seguir (o pósparto) durante os 40 dias, mas eu acho que eu segui um tempo menor. O pessoal falava mais por conta da alimentação, mas depende de cada atividade porque cada um tem um tempo. Então falavam que não podia fazer nada durante 40 dias; eles (familiares) falavam bastante da quarentena, assim como as amigas, na maternidade, na verdade, todo mundo brincava com a quarentena! Assim, deu 40 dias: eu tomei o chá. Pronto, acabou o resguardo! Na minha cabeça eram 40 dias (o pós-parto), mas na cabeça da minha sogra 42 dias, minha mãe sempre falou 40 dias exatos. A minha mãe até tinha chegado a comentar que ela não sabe direito, se é menina que você guarda mais ou se é menino, ela ficou em dúvida. Falaram ainda que (o pós-parto) de menino são 41(dias) e de menina dura 40. Ainda escutei que de menina seriam 42 dias e se eu tivesse menino seriam 45 dias, então, eu não poderia abusar! Eu não podia ficar lavando cabeça e nem ter cólica porque se eu tivesse cólica, eu iria ter cólica todo dia. Hoje faz 41 dias que ele nasceu, ela (mãe) não 
queria que eu viesse (na consulta), ela queria que eu ficasse em casa. Eles (familiares) falavam bastante mesmo que eu tinha que me cuidar nesses 40 dias. Ainda foi me passado por ela (mãe), que era pra mim me resguardar mais (no último dia do pós-parto), tanto que me falaram que eu não podia pegar dor de cabeça e pra eu me entupir no último dia de remédio pra dor de cabeça, só que eu não tomei! Também nos 3 últimos dias (do pós-parto), não lavei a cabeça, pois não me deixaram lavar e nem tomar friagem, além de ter que ficar dentro de casa para não correr o risco de dar dor de cabeça, de tomar friagem e passar nervoso. Dizem que no último dia, você tem que tomar um chá de arruda com pinga, só que eu tomei o chá só de arruda com açúcar queimado e, só não colocou pinga porque eu estava tomando remédio. Antigamente, (o chá de arruda com pinga) era para tirar a recaída. Ainda quanto à dieta, eu fiquei pensando em seguir um pouco porque se eu pegar (recaída), vou pegar com pouca quantidade, porque eu não tô exagerando, por conta disso, eu procuro seguir a risca essas coisas que as pessoas falam pra mim e, quero fazer tudo direitinho pra depois, mais pra frente, não falarem: "Ah, aconteceu isso com você porque você abusou!’. Se quebrasse o resguardo, quando eu ficar mais velha é que vou sentir (a recaída), pois agora que sou nova eu não vou sentir nada, mas quando eu ficar mais velha eu vou sentir dor dos ossos porque tudo fica mais sensível. Então, se eu tomar muita friagem e abusar muito, isso é perigoso! Porque como falam que (o sangue) sobe pra cabeça, isso daria febre e dor nos ossos, falam ainda que depois passa, mas virou o tempo ou sentiu frio, aí você sente muita dor nos ossos. Por isso, que em tempo de chuva, ela (mãe) falava que era para eu tomar cuidado porque senão eu podia quebrar o resguardo e, se eu não guardar a dieta, fica mais podre. Além disso, eu não podia tirar a água da banheira e nem estender roupa. Muito menos pegar na vassoura, no rodo, ir pro fogão e passar roupa, pois essas são coisinhas que ajudariam a dieta, por isso, eu deixei de fazer isso. Ainda me falaram que se eu passasse algum nervoso, (no último dia do pósparto), eu jamais sararia e daria loucura. Isso, todo mundo aqui de casa falava, então, você não pode ser contrariada. Se o pós-parto não fosse seguido teria a recaída, a qual seria uma espécie de dor de cabeça na dieta; se você continuar com essa dor de cabeça e se tiver dor na coluna, ela vai continuar, pois como falam eu não posso pegar nada na quarentena porque se eu pegar não tem cura, tanto que eu 
iria melhorar só na outra dieta, cura mesmo só na outra dieta. Então, se eu quebrasse (o pós-parto) poderia ter dor de cabeça muito forte e ficar com essa dor pro resto da vida, por isso eu fiquei até com medo (de lavar a cabeça) porque todo mundo falava que podia dar dor de cabeça. Ainda, se eu ficasse doente no resguardo, o resto da minha vida eu ia ficar doente, tanto que se eu pegasse gripe, eu iria ficar com gripe até morrer. Por isso, eu tinha que seguir o pós-parto para não ter recaída, então, nada de fazer esforço, além disso, só depois de 20 dias (podia lavar a cabeça). Eu até lavava (a cabeça), mas ela (mãe) ficava falando, que depois a mulher ficava toda bichada, quando envelhece fica com dor, a mulher que não se cuida na dieta fica mais frágil. Ainda falavam (mãe e avó) que teria que terminar a dieta com o intestino bom, senão só na próxima que melhorava.

\section{DSC: Cuidados no pós-parto: Evitando carregar peso e esforçar-se!}

Eu sempre soube que após você ter um bebê, você tem que fazer um repouso, fazer uma dieta. Falaram que eu não posso (sair), que eu tinha que ficar trancada, de preferência na cama e de repouso sem levantar peso. Além disso, a hora que o bebê dormir eu tinha que dormir, então, eu ficava deitada no meu quarto, enquanto, ela (mãe) cuidava do neném, mas ficar deitada pra mim era muito difícil. Mas, enquanto eu consegui repousar, eu repousei. O simples fato de levantar da minha cama e ir até a sala pra eles (familiares) já era um esforço, que poderia abrir o corte. Eu também não fiquei arrastando muito peso. Nem abaixar muito, não agachava e não pegava peso, então, eu repousei mesmo! Procurei ficar em casa, se eu saia era só em caso de necessidade mesmo, por isso era só repousar, só! Foi mais a questão de não segurar peso e varrer o chão. Eu só fazia arroz, o resto eu não fazia, não limpava a casa, não lavava a louça, mas foi mais durante 30 dias. Eu deito muito, mas ando também, só que agora eu fico muito mais assim deitada com ele assistindo televisão. Além disso, essas coisas de fazer muito peso, eu não faço mesmo. Também o que eu não fiz foi atividade física. Acabei parando porque não pode fazer esforço, principalmente, na parte do abdômen. Fiquei sem limpar a casa porque não podia me esforçar fisicamente, serviço de casa, não deixavam eu pegar uma vassoura e nem lavar louça, muito menos pegar uma cadeira ou até a bolsa do nenê. Ela (mãe) não deixava eu lavar a roupa por conta do esforço e de por a barriga no tanque 
para não pegar friagem na barriga, então, eu esperei, eu acreditei piamente que eu não podia estender a roupa porque quando eu levantava o braço doíam os pontos e (fazer força) poderia acontecer algo com os pontos, como sair antes da hora ou até mesmo não cicatrizar e ficar aberto. Então, eu não limpava a casa porque o peso podia abrir os pontos. Portanto, eu não varria a casa, não passava pano, não tirava pó, não espremia a roupa, apenas colocava a roupa na máquina e, de vez em quando, estendia, por hoje ser mais fácil. Todas as mulheres mais velhas que eu tive contato falaram que eu não podia estender roupa, por isso, dei mais preferência para o cuidado do esforço: procurar não estender roupa, não passar pano e nem varrer porque não podia ficar se abaixando. Quanto mais eu num pegasse peso, muito peso, melhor era minha recuperação. Eu considerava peso, situações como: pegar balde, pegar criança no colo, tentar arrastar alguma coisa, erguer a cama ou alguma coisa. Então, isso eu não faço como eu fazia antes, que nem ficar arrastando as coisas pra limpar, isso não faço mais, pelo menos por enquanto, mas depois, mais pra frente posso continuar fazendo, mas por enquanto não. A roupinha do nenê, eu gosto de lavar na mão, mas eu não podia lavar na mão, pois falaram que é ruim porque você fica meio forçando pra baixo, fica esfregando e fazendo força, daí falaram que não era bom eu fazer porque meus órgãos por dentro estão desnorteado e seria perigoso. Tanto que se eu desse banho nele, eu não pegava a banheira de água, pois era pesada, então, ela (mãe) não deixava nem eu erguer a banheira pra jogar a água. Até colocar o bebê no berço, ela (mãe) falava que era perigoso, nos sete primeiros dias, antes de tirar os pontos. Por isso, enquanto eu consegui repousar, eu repousei. Então, varrer até hoje eu não varri, passar pano, nada, pois pegar rodo e vassoura podia sentir dor nas costas o resto da vida. Ainda, falavam bastante também para não pegar gripe, por conta dos pontos, pra não ficar tossindo e forçá-los. Tanto que nada eu achava perigoso, eu só ficava com medo de espirrar ou quando eu tossia, tinha medo dos pontos estourarem, mas ainda continuo me cuidando, por isso, esses dias mesmo, eu estava morrendo de medo de espirrar! Mas, depois que caíram os pontos, eu já queria fazer todas as coisas e até deu pra fazer algumas! Que nem como estava tudo cicatrizado por fora, eu achei que a cirurgia estava tudo em ordem, então, eu andei de moto. Outra coisa que a minha mãe falava era que quando os meus pontos começassem a cair, era porque o umbiguinho dele já 
estava secando. Mas foi o contrário, quando o umbiguinho dele caiu, aí sim meus pontos começaram a se soltar.

\section{DSC: $O$ autocuidado para a higiene...}

\section{...da cabeça}

Eu evitei lavar a cabeça, fiquei mais de 15 dias sem lavar. Eu fiquei com um pouco de medo de lavar (a cabeça) porque eu estava menstruada, mas daí esperei mais ou menos uma semana, mas não agüentava mais, então, lavei. Mas, na verdade, eu acho que (não podia lavar a cabeça) por causa da cólica no nenê devido a friagem, mas também mandaram não lavar a cabeça pra não dar cólica também em mim. Ela (mãe da cunhada) ainda me falou (para não lavar a cabeça), pra não pegar a friagem, por isso tomei cuidado pra não dormir com o cabelo molhado porque falaram que não fica bem depois, além da cabeça ficar muito frágil. Eu também não podia cortar cabelo porque você lava, e lavar poderia dar tontura, tanto que eu lavei e tive um pouco de tontura, então, lavar a cabeça dá tontura! Ela (mãe) falava que lavar a cabeça daria dor de cabeça; enquanto eu lavava não, mas depois iria sentir muita dor, por isso, fiquei sem (lavar) a cabeça. Portanto, (se lavasse a cabeça) iria ficar eternamente com aquela dor de cabeça, que duraria até o próximo pós-parto, ela (mãe da cunhada) falou isso. Então, até esperei bastante tempo (para lavar). Na realidade, falaram que depois que eu passar pela médica, eu poderia lavar a cabeça, mas mesmo com medo, eu lavei e sequei, mas só lavei porque estava sol, mas eu não poderia ter lavado a cabeça. Então, até eu tirar os pontos, eu realmente num lavei o cabelo por conta da cesárea.

\section{...da incisão}

Eu lavo bem (os pontos). Até comprei um sabonete na farmácia. Usei o sabonete íntimo mesmo, mas ás vezes eu lavava só com água e sabão, pois pra fechar tem que higienizar e não ter nenhum tipo de infecção. Algumas vezes, eu usava só um sabonete pra lavar os pontos, sabonete normal mesmo, pois não precisava ficar passando produto nenhum pra cicatrizar mais rápido. Eu lavava com sabonete mesmo: esfregava bem, mas no comecinho eu fiquei com medo, eu passava a mão de 
levinho (nos pontos) porque eu morria de medo de passar a mão. Além disso, secava bem de levinho com medo dos pontos caírem, e depois que tirei os pontos eu passava normal (a mão). Como o corte acho que é plástico, quando eu ia lavar tinha que ser bem cuidadosamente, bem devagarzinho passando sabonete, jogando a água com chuverinho, nem era chuveiro forte, então, foi só uns 7 dias porque depois que eu tirei os pontos eu deixei de fazer tudo que eu tava fazendo. Além disso, até semana passada eu tava menstruando ainda, então eu sempre troquei de absorvente 4 por dia.

\section{DSC: A friagem: Um perigo que ronda o pós-parto}

Ainda pensando na minha proteção, eu fiquei durante os 40 dias dentro de casa, para não tomar friagem, não saia na rua, só ficava em casa resguardada de meia, com pantufa e coberta na hora de dormir porque não pode tomar frio e nem sereno. Também não podia tomar friagem, aquela friagem das 6 horas da manhã. Eu não consegui deixar de andar, lavar uma louça, torcer uma roupa, então, coisas assim eu continuo fazendo normalmente, pois não tive nenhuma orientação pra não fazer, só evitei mesmo pisar no chão para não ter friagem demais porque cólica ninguém merece! Pois ficar menstruada dá cólica, então como daqui a pouco eu vou menstruar, eu evitei. Também não estou saindo à noite, tudo por causa da friagem, então, ainda ela (mãe) fala pra não andar descalça. Na realidade, eu sempre soube que não podia andar descalça, então, eu não andava descalça e nem saia no vento e, se eu saísse tinha que ser com blusa, mas não podia andar descalça porque a friagem vinha pelo pé! Por isso, eu evitei ficar pisando no chão frio e lavar o quintal porque o pé molha demais, e ficar com o pé no chão, porque daria cólica se a gente ficar no gelado e tomando friagem. A mãe da minha cunhada dizia pra não andar descalça por modo da friagem. Para prevenir isso, nos primeiros dias, eu ficava com calça de pijama e meia, mas depois de um tempo falavam que eu tinha que ficar usando moletom, blusa de frio, roupa mais quente, além de viver de chinelo e meia. Para se manter aquecidinha tinha que usar blusa de frio e muita roupa de frio junto. O problema maior era a questão da meia no pé durante a parte da tarde porque eu passo muito calor, assim como usar muita blusa de frio também. Fora isso, não podia tomar água gelada, nossa! Tomar gelado, nem pensar! Por causa da friagem! 
Se eu tomava sorvete, eu tinha que tomar um copo de água quente por cima depois. Eu seguia isso porque toda friagem que eu pegasse, passaria pro nenê; que nem se eu ficar gripada por conta da friagem, ele (bebê) também ficaria. Também não podia deixar a mão ficar gelada porque se você catar o nenê, você passa a friagem pra ele (bebê). Na verdade, eu não sei muito o que a friagem causa, nem sei se é pra mim, se é pro bebê, na verdade, eu não cheguei a perguntar pra elas, a única coisa que eu sabia era que elas ficavam no meu pé pra usar meia. Além disso, se eu tomasse algum vento, o sangue que estava descendo pela menstruação, iria subir para a cabeça, por isso, eu não lavei mais (a cabeça) porque falavam que era perigoso, eu fiquei meio com medo e por via das dúvidas a gente não faz.

\section{DSC: Deixando a beleza meio de lado...}

Antes eu cuidava mais de mim, tinha mais tempo. Agora, não consigo não, ainda não, que nem a unha não dá pra cortar, porque num tenho tempo. Que nem arrumar o cabelo, essas coisas bem femininas, eu ainda não consegui. Eu acho que os cuidados da beleza vêm depois, tanto que os pêlos do braço eu também parei de descolorir. Eu faço a definitiva e ainda não fiz, assim como pintar cabelo, né, a tintura de cabelo não estou mais fazendo, então, isso que é mais coisa de mulher assim eu num faço ainda porque estou esperando a orientação médica. Eu falo mais (de não ter tempo) assim de arrumar a roupa e a unha, mas a depilação, eu só fui fazer semana passada e foi com o maior cuidado, pois eu ainda não tinha conseguido raspar (os pêlos) por causa dos pontos, mas comigo eu não estou conseguindo ter muitos cuidados. Outra coisa que eu não podia era passar muita química porque falavam (familiares) que vai para o couro cabeludo, e do couro iria pro sangue e, depois para o leite e para o bebê, mas agora, acabando os 40 dias, já me liberaram pra tingir o cabelo. Mas mesmo assim, não posso fazer muita coisa. Eu faço escova definitiva, mas não pode por causa do formol, por isso, minha mãe não deixou. Minha mãe ainda falou que não pode (descolorir os pêlos), que vai pro leite, que seria igual a pintar o cabelo, tanto que eu tingia meu cabelo, mas agora eu não posso, só daqui 13 dias minha mãe disse, mas mesmo assim ainda preciso confirmar com a pediatra. Na verdade ela (mãe) falava que eu não podia pintar o cabelo na dieta, pois eu estava amamentando, então, só depois que eu parar de amamentar é 
que eu vou poder pintar meu cabelo. Só depois que a criança estiver maior um pouquinho, acho que depois de uns 6 meses (que poderei tingir o cabelo). Ah, para ir ao dentista, eu também esperei porque o que era pra tirar, como: cortar o cabelo, tirar as sobrancelhas, raspar as pernas, cortar e lixar as unhas, arrumar um dente eu sinto falta, mas isso poderia dar alguma inflamação e afetaria de algum modo os pontos. Isso de cortar o cabelo é superstição, mas eles (familiares) não querem (deixar) porque eu senti tontura (depois de lavar a cabeça), mas o leite continuou normal e dor de cabeça, eu não senti. Outra coisa que me falaram é que vai cair o cabelo dele (bebê). Vai cair o meu também porque ele já reconheceu. Na verdade é porque ele já conhece a mãe dele quando começar a cair o cabelinho! Eu também deixei de passar perfume, pois tenho medo do cheiro ficar muito forte pra ele (bebê); nem em mim era bom (passar perfume) por causa da alergia que o nenê pode ter. Então, eu era preocupada em ver o que eu posso passar e o que eu não posso, se vai fazer bem pra ele ou não, que nem eu sei que na região aqui (se refere às mamas) eu não posso passar por causa do bico, pois ele vai mamar e vai ter contato com o creme, mas no resto do corpo eu estou passando. Então, uma das únicas coisas que eu mantive foi o creme, mas eu procurava não passar em lugar que ele (bebê) tinha contato, como no pescoço e no peito, que é onde ele (bebê) fica bem perto de mim.

\section{DSC: Vestindo-se no pós-parto e cuidados com a estética}

Os únicos cuidados foram que eu ficava de cinta, meia, blusa de frio e calça, mas o uso da cinta é o único cuidado que eu tô tomando. Eu usei a cinta desde que eu sai de lá (maternidade), na verdade, depois de dois dias eu consegui colocar a cinta, daí eu conseguia andar melhor e não doía por isso eu usava o dia inteiro, a noite inteira, só um período eu tirei e parei de usar um pouquinho. Além disso, eu sempre colocava a calcinha bem pra cima como forma de proteção, pra proteger o ponto. Eu acabo usando mais pra segurar a barriga pra não ficar barriguda, mas como eu disse, nos primeiros dias, eu sentia mais segurança por causa do corte. Esse cuidado (o uso da cinta) as pessoas passam por conta da barriga, fala que é para a barriga não ficar flácida. Todo mundo falava que você tinha que usar (cinta) porque emagrece e volta mais fácil. Se você não usar, você se arrepende, por isso eu tenho usado sim. É uma coisa muito feia, mas eu sei que é pro bem, tanto que parecia que 
estava tudo oco por dentro e usando a cinta parecia que estava mais direitinho. $\mathrm{Na}$ verdade, dava mais segurança pra andar. Mas eu me lembro também, que quando eu cheguei em casa, me senti incomodada um pouco por causa de amamentar, que não dá pra dobrar o corpo direito, então, agora, eu estou usando só a calcinha que é mais alta, que ajuda comprimir também bastante, assim como usar roupa mais com lycra, né, pra apertar mais a barriga. Eu cheguei a usar uma cinta da Trifilß, que é de meia calça, mais confortável e uso até por uma questão de segurança por medo de acontecer alguma coisa com os pontos. Eu até vi que foi comprovado cientificamente (o uso da cinta) e que dá resultado, que faz o corpo voltar ao normal, além de ajudar a firmar mais a pele, então, não é tanto questão de saúde (a cinta) é mais questão de estética. Quando a cinta que eu usava ficava larga, eu ia trocando, então, eu estava com uma (cinta) que amarra embaixo e, ela relaxou, depois disso, eu comprei aquela só da cintura e usei roupa larga.

\section{DSC: Descobrindo a "mãe do corpo"}

Falaram que a barriga faz uns barulhos enormes, que você até assusta e, eu, na verdade, já senti alguma coisa assim! Então, eu senti dai eu falei: "Nossa! Que que é isso?", dai minha mãe falou que é a mãe do corpo procurado a criança na barriga, pois falavam que ele (útero) estava solto porque o nenê abriu lá e, (útero) ficou solto lá dentro, então, meu útero ficava dançando lá dentro e por isso eu não podia levantar peso pra ele se assentar de novo e direito. Ela (mãe) ainda falou que se eu varrer e rodar a casar, a mãe do corpo não volta, ela (mãe do corpo) fica andando; parece que eu tô grávida pro resto da vida. Ainda me falam que ela vai ficar mexendo e não vai voltar pro lugar. Isso aconteceria se eu quebrasse a dieta, se eu limpasse a minha casa. Então, pra ela (mãe do corpo) voltar pro lugar, eu não podia fazer esforço porque se eu fizesse esforço, muito forte, ela (mãe do corpo) podia sair pra fora e depois tinha que voltar no médico pra colocar pra dentro de novo. Tanto que ela (mãe) falou que (a mãe do corpo) fica andando e que isso serve pra mulher descansar depois do parto e não ter relação, ela (mãe) até chegou a falar que dentro da mulher fica o sangue, e o sangue pode virar e com isso ficaria mexendo na barriga como se tivesse um nenê; por isso, depois que o nenê nasce ela (mãe do corpo) fica procurando o nenê dentro da barriga. Como eu estava sentindo 
( a mãe do corpo), a minha mãe comentou que a mãe do corpo faz isso para voltar pro lugar dela. Eles ainda falaram que (a mãe do corpo) parece um bixinho andando dentro de você. Ela (mãe) falou que era tipo uma minhoca, tipo uma lumbriga, mas eu acho que é o útero porque ela (mãe) fala que é aonde sai o bebê, então, é o útero (a mãe do corpo).

\section{DSC: Sexo: Nem pensar!}

Eu estou de resguardo, depois que ele nasceu eu não tive relação. Fomos eu e ele, que preferimos não abusar (não ter relações sexuais) pra não correr nenhum risco. Por isso, fiquei quietinha, sem relação mesmo. Vale salientar também, que eu não tive relação nesse período porque não to tomando ainda nenhum tipo de anticoncepcional e por conta do medo do esforço, que pode estourar alguns pontos por dentro. Na maternidade, todos falavam da quarentena, que tinha que deixar de ter relação. Todo mundo fala. Falaram que eu não podia fazer (sexo), que se eu fizesse eu iria acabar engravidando, mesmo se eu tivesse usando camisinha, pois a camisinha iria estourar porque o corpo está ruim, tanto que elas (tias) só falaram para evitar, não deixar a camisinha estourar, porque o corpo estava áspero e sensível por dentro, então, a gente fica com tanto medo que aconteça alguma coisa, que acaba não fazendo. Então, relação sexual não podia. Até agora não (teve relação sexual)! Sem querer eu passei meu resguardo sem ter relação sexual porque eu não tive esse tempo de pensar em ter relação.

\section{DSC: Amamentação: Das crenças às novas formas de cuidado}

Pra mulher que teve neném, me disseram que é muito bom pra amamentar comer o pirão, que é tradição na minha região, outra coisa é a canja pra aumentar o leite. Eu ainda bebia aquele líquido que ficava lá sobrando da canjica. Não era pra comer a canjica. Eu bebi, só uma vez, cerveja preta também (para aumentar a produção de leite), só que ela (mãe) não deixou porque nós procuramos na internet e encontramos escrito que, mesmo a cerveja preta tem álcool, então não é bom. Outra coisa que ela (mãe) fez, foi tudo que eu comia e sobrava, ela (mãe) pegava e colocava em uma sacolinha pra enterrar, pra nenhum cachorro comer para eu não perder meu leite. Além disso, aonde caísse meu leite, na blusa, tudo, ela (mãe) 
lavava em água corrente antes de colocar pra lavar por causa do risco de roubar o leite... Eu até achava esse negócio do leite uma mentira, na verdade, não podia deixar cair ou pingar leite no chão; também, se alguma pessoa viesse te visitar nos primeiros 7 dias tinha que perguntar se a pessoa estava menstruada porque senão ela leva seu leite embora, daí você tinha que fazer uma comida e chamar a pessoa pra comer com você. Mas eu acho que o meu leite secou mesmo porque pingava no chão, eu estava me secando (após o banho) e o leite vazava, então, ou eu me secava ou ficava segurando, por isso, eu acho que foi por causa disso (pingar no chão que o leite secou)! Então, se você estava dando leite e entrasse alguém menstruada em casa, seu leite iria secar, ai cada coisa! Mas é isso! Por isso, se você estiver amamentando e a mulher estiver menstruada, ela tem que avisar senão o leite seca. Tive problemas com a amamentação, tive até que comprar um bico pra ajudar a produzir leite. Na verdade, eu tive esse caroçinho, mas (o leite) estava empedrado e doendo, então, coloquei a polenta, mas não adiantou, também tentei a simpatia do pente, que você passava o pente para desmanchar o leite empedrado, também fui jogando água quente e fazendo massagem, fui massageando o peito e melhorou. $O$ que também salvou (o peito) foi passar o leite materno que eu vi no site de pesquisa (na internet). Passo ele (leite materno) na mama e mais a pomada que ele (RN) poderia colocar a boca. Eu ainda passo a pomada pra ajudar (amamentação), mas quando rachou o bico, a única coisa que eu fiz foi passar o leite, o meu próprio leite sempre, passava em volta da aréola e sarou. Ainda pensando na amamentação, outra coisa que me preocupei foi com o absorvente de seio.

\section{DSC: Sentindo-se pressionada: A transição da mulher para ser mãe}

Eu acredito que, no começo, até esqueci um pouco de mim, acabei meio que me anulando em algumas coisas pra não prejudicar o bebê, além disso, no começo tudo é novo, a gente não sabe como é, e querendo ou não mudou bastante por causa dele (bebê). Eles (familiares) não cobravam pra eu me cuidar. Eles cobravam pra eu cuidar do nenê. O problema é que falta informação pra saber o que você vai fazer nesses 40 dias. Falta informação também nessa parte (fechamento do resguardo) porque mostra mais o que você tem que fazer com o bebê. Além disso, no período que o nenê tivesse dormindo era pra aproveitar pra descansar! Durante esses 40 
dias: não pode isso, não pode aquilo... Todo mundo te fala e te pressiona, então, eu acabei meio que me desgostando. Tem também essa preocupação, que eu acho muito mesquinha da parte das pessoas, mas você tem que tá bonita pra receber visita. Até me pressionaram que tinha que sair de cinturinha (para usar a cinta) e, eu sabia que não ia sair de cinturinha.

\section{DSC: Crenças e cuidados do recém-nascido}

Eu demorei um pouquinho pra sair com ele (RN). Minha sogra falou que ele (bebê) estava amarelado, então tinha que dar banho de picão e eu dei. Usei pétala de rosa branca por causa das coisinhas que ele (bebê) tem no rosto pra secar e eles (familiares) ainda mandaram colocar maisena na água dele (bebê). Ela (mãe) também não deixava eu lavar o cabelinho dele (bebê), então eu só passava a mão molhada, nunca fui de ficar lavando com shampoo. Eu fiquei com medo de espirrar (perfume em mim) e ser muito forte, tanto que eu acho que até loçãozinha pra ele (é forte), às vezes, a minha mãe até fica falando: "Não passa muito, porque às vezes ele é alérgico e a gente não sabe!" A minha irmã também falava pra eu não passar perfume nele, que ele pode ter alergia. Além disso, a roupa do bebê, ela (mãe) não deixa torcer porque fala que dá cólica nele (bebê) até os três meses, (a roupa do RN) não pode tomar sereno e tem que deixá-lo com meia senão dá cólica. Minha avó e eles (familiares) falavam sobre tomar cuidado quando for colocar a roupa do nenê no varal, deixar a noite inteira e pegar só no outro dia porque não pode tomar sereno da noite nem as neblinas que pode dar cólica no nenê. Eu ainda dava chá pra cólica do nenê. Eu preferia chá de camomila e erva doce, porque falaram que iria pro leite e ajudava a acalmar o bebê e ajuda nas cólicas. Também me falam bastante que se ele tiver soluço, pra colocar uma bolinha de linha na testa dele (bebê). Eu não acreditava, mas hoje, eu acredito que funciona. Eu mesma até coloquei fitinha no braço dele, vermelha, pra evitar olho gordo... Mas, na verdade, até em mim, ela (sogra) já colocou uma coisinha vermelha para os outros não ficarem colocando olho gordo em mim. Eu já sabia disso porque fui aprendendo sozinha, mas mesmo assim ela (sogra) colocou e eu coloquei nele (bebê)! Ainda fiz chá do talo da alface pra ele dormir, fizemos (puérpera e familiares), e ele dormiu a noite inteira. Também falaram daquelas famosas simpatias de colocar o nenê com a cabeça pro 
outro lado do berço, colocar pro lado contrário do berço, então, eu colocava ele na cabeceira da cama durante o dia e, a noite voltava ele para os pés da cama, isso eu faço quando ele não dorme a noite. Teve uns dias que ele (bebê) estava trocando o dia pela noite, dormia de dia, que era uma beleza, chegava à noite estava com o olho regalado, então, eu mesma procurei na internet: "simpatia para crianças que trocam o dia pela noite" e vi, que falava pra virar o pagãozinho ou a blusa dele do lado do avesso e dar um banho nele às seis horas, depois desse dia, o nenê dorme que é uma beleza! Ainda, se a criança estiver dormindo de barriga pra cima, não pode levar susto porque dá uma doença no bebê. Como o umbigo dele está estufado falaram pra dar três (estalos), fazer três vezes (três estalos) na água e depois afundar o umbigo dele ou colocar uma moeda com um pedaço de algodão, mas eu num fiz porque eu fiquei com medo, pois a moeda e suja né, alguns momentos eu tentei colocar só a faixinha, só! O umbigo (do bebê) foi ela (mãe) que cuidou, além dos cuidados para o nenê ficar coberto e não tomar friagem. Ela (mãe) ainda guardou (coto umbilical) porque se perdesse ficaria louco, se o rato comesse viraria ladrão, isso era o que a minha mãe ensinava, então, ela (mãe) guardou para enterrar. Na verdade, falou que tem que enterrar e ainda disse que quem corta a unha (do bebê) é a madrinha, ela (mãe) não deixou eu cortar. Como ele (bebê) está com a unha encravada, minha avó fez uma mistura de cânfora com fumo para passar no pezinho dele (bebê). Queria falar ainda que com o bebê, eu também tive cuidado, no sétimo dia (após o nascimento): na verdade, eu não pude sair, nem levar o nenê na pediatra por causa do mal dos sete dias. Não podia sair da porta pra fora tanto que durante os sete dias eu não podia sair nem na rua, muito menos com o nenê!

\section{Domínio: ESPIRITUALIDADE}

\section{DSC: Mantendo a religiosidade}

A única coisa que eu sempre fiz: vou na igreja. Quando ele nasceu, eu o apresentei quando ele estava com nove dias porque sou evangélica e com nove dias a gente tem que apresentar a criança. Como vou na igreja evangélica, eu não acredito (em simpatia). Mas, antes de dormir, eu deito do lado dele, fico olhando a carinha dele e faço uma oração para nós. Além disso, ela (mãe) mandou eu batizar ele logo. 


\section{Domínio: PRÁTICAS DE CUIDADO À SAÚDE}

\section{DSC: Mudanças de hábitos no pós-parto: Tornando-se mais responsável}

Eu tomei certos cuidados de maneira natural, não porque me falaram, mas foi uma coisa bem natural! Que nem a bebida, eu parei de beber pra não ir pro leite, também deixei de andar de salto, pra não correr o risco de cair e estourar os pontos. Outra coisa que deixei de fazer é passar perfume, eu não uso muito porque ele fica muito aqui (no colo, região próxima ao pescoço), tenho mais atenção só com perfume muito forte e também tô evitando por causa do neném. Eu estou lavando as mãos toda hora, lavo a mão para pegar ele, tomo banho toda hora porque você fica suada, tudo por causa dele (RN). Eu passo (maquiagem) e lavo a mão por causa do nenê,, pois pode passar um pozinho e dar alergia nele. Como eu disse, às vezes, eu tomo mais banho do que já tinha costume porque aumentou mais a preocupação (com a higiene), os banhos têm que ser rapidinho, então, vou amamentar e vejo que estou meio suada, tomo um banho, pois você se preocupa com isso. Também deixei de andar de bicicleta, deixei de dançar e esperei 30 dias (para andar de moto). Eu evitei sair, tanto que repouso, o que eu mais parei de fazer foi de sair, eu preferia ficar em casa mesmo. Tudo que falaram pra mim eu segui, mas até os 40 dias só, depois foi normal. A única coisa que eu fiquei com medo de fazer foi (sobrancelha de henna) por causa do leite, mas foi bem pouco que eu usei (para fazer) e foi só uma vez, mas a tinta, por enquanto não pode enquanto está amamentando.

\section{DSC: Aprendendo com a vida e se atualizando com as redes sociais}

Eu aprendi com a vida, que com cirurgias, tem coisas que não deve comer devido à cicatrização. Quando você põe piercing ou faz tatuagem, você não pode tomar coca e comer carne de porco porque isso prejudica na cicatrização, então como eu já fiz tatuagem eu levei isso em consideração, pois já sabia como que era! Até cheguei a procurar na internet sobre alimentação: procurei o que dava gases (no bebê) $e$ descobri que tem bastante coisa, como brócolis, couve-flor, leite, doce de leite e os derivados do leite. Essas coisas de (lavar a cabeça) eu já sabia, estava bem longe, 
mas foram me relembrando. Tanto que (o uso do absorvente de seio) foi um cuidado que ninguém me disse, que eu descobri sozinha. Foi o Google que me mostrou, então, foi pela internet que eu comprei (absorvente de seio) e comecei a usar. Eu pesquisei em sites, pesquisava bastante na internet, tanto eu como minha irmã, a gente procurava se tem remédio para a estria, o que dá estria, o porquê da estria até hoje a gente não descobriu, mas que tem remédio tem. Por isso, procurávamos se tinha remédio caseiro pra estria. Eu procuro na internet até remédio pra olheira. Eu ainda fiquei sabendo, quando procurei na internet, que nem todas as pessoas eram iguais.

\section{DSC: Acreditando no benzimento}

Eu tenho que levar o bebê; ele tem que ser benzido porque está assado e por causa do rostinho dele. A criança (bebê) estava mole e sonolenta, então ela (sogra) queria que levasse pra alguém rezar. A minha mãe também estava querendo (levar para benzer). Eu realmente levei ele (bebê) pra benzer umas duas vezes porque eu acredito, tenho essa crença, eи benzi meu filho, uma vez eu liguei pra benzê-lo por causa do quebrante e do mau olhado. Então, levei ele (bebê) pra benzer quando estava com 10 dias. A benzedeira disse que ele (bebê) estava com quebrante, ainda falou que eu mesmo passo quebranto pra ele (bebê) porque sou mãe coruja. Tanto que a benzedeira e a minha sogra falaram que o pouquinho que você fica: "Ai nenezinho lindo!", você já coloca (quebranto). Daí, se ele ficasse com quebrante, tem gente que fala pra beijar a bundinha dele, não na hora que a pessoa está ali, mas depois que a pessoa for embora deve beijar porque às vezes tem criança que fica com quebrante e não dorme, fica chatinha. Tanto é que se ele começasse a chorar muito, eu tinha que fazer o sinal da cruz três vezes na testinha dele, além de colocar a blusinha dele (bebê) do lado avesso. Às vezes ela (mãe da cunhada) até benze o nenê pra quebrante. A avó dele por parte de pai, toda vez que ele (bebê) boceja diz que é pra fazer o sinal da cruz no cantinho da boca; ela (mãe) ainda diz que a mãe tem o dom de benzer o próprio filho. 


\section{Domínio: PROVEDOR DE CUIDADO À SAÚDE}

\section{DSC: As opções de cuidado no pós-parto: Seguindo as orientações de vários provedores}

Eu já tinha lido (sobre a mãe do corpo), isso acontecia porque ele (o útero) estava voltando no lugar, então, acabavam fazendo uma massagem na maternidade, pra ajudar o útero voltar ao lugar. A enfermeira, o médico, o pessoal lá de casa e minha mãe falaram pra mim que não podia (ter relação durante 40 dias), mas a gente também não tem vontade (de ter relação sexual). Ela (mãe) falou que as comidas fazem mal porque por dentro ainda está com corte e demora um ano (para cicatrizar); o médico falou que demora um ano pra cicatrizar. Ele (amigo) também falou que se o ponto cicatrizou por dentro, por fora também já tinha cicatrizado. Agora, informação, na verdade, foi tudo por via familiar, porque eles (profissionais) pegam e falam, mas lá (maternidade) eles não me falaram nada. Além disso, a mãe dele (companheiro) não deixava tomar café de jeito nenhum, mas na maternidade eles deram café com leite, o que não pode é tomar café puro por causa da cafeína, que é forte e dá cólica, daria cólica em mim e passaria pra ele (bebê) pelo leite. Eu estou seguindo a orientação das famílias e da pediatra. Sobre a faixinha, foi minha mãe, minha avó e também um farmacêutico que falaram que era bom colocar pra ver se (a hérnia umbilical) volta ao normal. Medicamento era o paracetamol®, o médico e a minha madrasta que falaram que era bom, a minha irmã também acabou falando (do paracetamol®). Eles falavam que quando eu ficasse com dor de cabeça eu tinha que tomar um remédio que não fosse muito forte. Então, o único medicamento que eu tomei foi a dipirona®, que não era assim aquela coisa! Além disso, só tomei simeticona® pra não ter gás e nem a nenê.

\section{DSC: Cuidados pautados nas orientações dos provedores da saúde}

Eu procurei na internet se tinha remédio pra estria, se tinha pomada, ainda perguntava pro doutor se tinha algum remédio. Da minha parte o que eu precisava saber eu já procurei (pesquisando na internet), agora mais pra parte dele (bebê) que eu me preocupo. A pessoa que eu tenho mais contato é a minha mãe, então, tudo quem me passava era ela; tinha um pouco de livro e da internet; tinha também a minha sogra e a minha avó. Na verdade, algumas coisas eu aprendi com o tempo, 
porém as pessoas foram falando, o médico também passou a orientação de não estar fazendo isso (tingir o cabelo). Eu sempre fui procurando em site coisas de alimentação, minha mãe mesmo reforçava (orientações antigas). Eu li no material da escola que por dentro fica mais sensível, então, se a gente faz muita força, aí é perigoso abrir por dentro (os pontos). Já o que a minha sogra e o pessoal falavam, eu procurava não dar muita bola não. Mas, eu ouvi muito sobre água no ouvido: 'Tomar banho e secar com o cotonete, viu! Senão vai dar dor de ouvido e daí o neném vai ficar irritado. Dentre as orientações, a única orientação mesmo que eu tive foi a questão de lavar o cabelo, que realmente, por ter feito cesárea poderia me dar algum problema. Sobre amamentação eu vi por muito tempo as tias, primas, mãe e até minha irmã amamentar, então, eu acabei aprendendo sozinha através de observação e não tive dificuldade. Ainda a única orientação que eu tive foi dar "chuquinha”, então, até hoje eu não dou no copinho, por isso considero que foi outra orientação que eu não recebi (sobre oferecer o leite materno no copinho). Por isso, tudo que falavam eu atribuía pra mim, o que eu não achava (coerente) eu descartava, deixava entrar por um ouvido e sair pelo outro, mas tudo que eu achava que era certo até hoje eu tô fazendo. Atualmente, se eu conhecesse alguém eu falaria: 'Oh, não faz isso na dieta não porque é perigoso...', em seguida, eu falaria: 'Ah, eu fiz, em mim não deu nada, mais vai que você faz e dá...então não segue essa recomendação não!’.

\section{DSC: O cuidado determinado pelo profissional de saúde}

Eu perguntei pra uma enfermeira, quando eu fui tirar os pontos, se eu podia andar porque falaram pra mim não fica andando, que era recente, nem em ônibus podia subir, ai a única coisa que eu ouvi, na maternidade, é que pra cicatrizar por dentro demora um ano e por fora diz que é rápido, mas depende da pessoa. Daí no postinho, eu até perguntei pra enfermeira, ela falou que era 3 meses pra fechar totalmente, cicatrizar, mas pra carregar peso, realmente, só depois de um ano pra voltar às atividades normais porque é perigoso abrir... Até os médicos falam que eu tinha que cuidar do corte pra não inflamar, pra não dar problema, além disso, o médico só me deu uma vitamina pra tomar, que eu acho que é pra ajudar na cicatrização. A moça lá do posto, a enfermeira, falou que eu tinha que secar bem (os 
pontos) senão pode ficar com aquele cheiro. Lá na maternidade, as enfermeiras falaram pra mim cuidar bem do corte, pra não passar nenhum tipo de pomada e lavar com água e sabão e, depois que eu fui no postinho e tirei os pontos, ela (enfermeira) me mandou continuar lavando só com água e sabão. Na maternidade, a enfermeira chefe falou que tinha que usar cinta até os 40 dias, porque o útero demora 40 dias para voltar ao normal, além disso, eu só escutava que se fizesse esforço pra levantar a cabeça eu poderia sentir muita dor de cabeça, então a enfermeira ainda me disse que eu não podia erguer a cabeça porque iria pegar uma enxaqueca que não iria mais sarar. Quanto a carregar peso eu não tô carregando, porque a orientação que tive na maternidade é de um ano sem carregar peso. Acabam falando mais do bebê, mas também falaram dos cuidados com a cesárea, que é pra ficar em repouso, não carregar e nem pegar peso. Mas os médicos, quando foram me ver, ainda na maternidade, falavam pra mim andar bastante pra recuperar logo. Eu, no posto, aprendi bastante por conta das palestras de como dar banho e como cuidar do nenê. A pediatra ainda me disse que durante 3 meses a gente tá ligado, eu e o neném, então tudo que eu estiver sentindo de dor o nenê vai sentir, por isso o melhor é eu me cuidar. Mas, eu não pude tirar as dúvidas que eu queria, porque você vê na cara do pediatra que ele quer que você saia logo (da consulta)! Quando eu recebi alta, perguntei se tinha alguma restrição e, ela (médica) me disse que não, que eu podia comer tudo, normal. A única coisa que ela (a médica pediatra) pediu era para comer tomate, então, eu voltei a comer, também pediu pra mim evitar suco de laranja, de limão que é muito ácido; o café ela liberou, mas sem excesso porque no meu caso eu precisava. Uma enfermeira, falou que eu tinha que comer de 3 em 3 horas. Sobre o resguardo sexual, o médico disse que (o resguardo sexual) era pra não doer, não me machucar e também pra não correr o risco de ficar grávida. Eu achei que o pessoal falava muito mesmo da questão sexual: no dia que eu fui tirar o ponto, a enfermeira me perguntou, uma mocinha aqui (do posto de saúde) falou no dia da revisão do parto, até quando eu fui ao médico, ele me perguntou (sobre a sexualidade); aqui no posto, eles (profissionais de saúde) também falaram pra mim que se eu quisesse eu podia ter (relação sexual) normal, só que era pra usar camisinha, pois a pílula só iria vir depois dos 40 dias, mas isso (cuidado com a relação sexual) não (foi dito no hospital): eu até tô 
tentando falar pro médico, com medo de dar alguma coisa por causa disso (ter mantido relação sexual antes dos 40 dias), né! Porque eu ainda não sei o motivo que a gente não pode, eu não sei...

\section{DISCURSO DO SUJEITO COLETIVO DESTOANTE DOS DADOS COLETADOS}

\section{DSC: Rompendo com os paradigmas sobre as práticas de cuidado no pós-parto}

Eu não fiz mais porque foi cesárea, e também devido o risco de abrir os pontos, mas foi só nos primeiros dias. Acho que resguardei umas duas semaninhas, então, foi até uns dez dias só, que eu fiquei fazendo essas coisas assim (resguardando)! A questão que tem que ficar 40 dias, que não pode isso, são passadas mais pelas senhoras de idade. Elas têm o costume de seguir essas dietas, mas não tem necessidade de ser tanto! Então, indiretamente, você não tem necessidade de ficar 45 dias sem fazer nada, que não dá também! Então, eu tive o bebê e não fiz nem metade do que dizem que tenho que fazer. Eu até acatei algumas opiniões, mas eu segui a minha, na verdade, até falavam pra mim o que realmente tinha que fazer, como se resguardar, mas eu já sabia assim, que eu tinha que resguardar. Eu segui um pouquinho (a dieta), não tão rígida, mas, até que eu me resguardei, um pouco! Como eu não fiz muito tempo (dieta), pois todo mundo fala e não sabe explicar, né, não segui, por isso. Ás vezes, eu acho que eu não segui não (a dieta)! Isso porque eu também não fiquei de repouso, na verdade, só nos primeiros dias: eu não varri, não lavei roupa e fiquei mais sentada com ele, procurei deitar, mas só nos três primeiros dias, além disso, no começo da dieta, não forcei muito peso. Por isso, a questão de repouso é assim, eu acho que fiquei três dias tranqüila, mas conforme eu vi que eu já podia me levantar, mesmo com dor, eu voltei fazer minhas atividades normais, pois também não gostava de ficar de repouso; eu fiquei dois dias e já saí no segundo dia com ele. $E u$ acho que até tomei friagem demais, pois não segui muito não (a questão da friagem): uma porque eu não gosto de por meia no pé, então, pra mim dormir de meia me irrita. Então, ficar 40 dias de meia, morrendo de calor, eu falei: 'Não vou ficar não'! Porque eu sou muito calorenta no pé, daí era difícil e mesmo assim elas ficavam no meu pé, mas eu não (usou meia e roupa de frio) porque eu sou muito 
calorenta. Além disso, eu andava descalça, eu mexia com água, eu não ficava em casa e ainda tomei chuva. Eu acho que me esforcei bastante, levantei, andei bastante, pois falam que eu não posso, mas eu não tô nem aí. Jogar a água da banheirinha eu não jogo pra não levantar muito peso, mas se for para lavar uma roupa, eu lavo, mas se for pra pegar bacia ou balde ou alguma coisa as pessoas vão, não pego mesmo sem ninguém. Tanto que só acabei quebrando (a dieta) porque eu tive que pegar a vassoura e o rodo, mas limpei tudo normal, falei que não dava nada não! Limpei e nada aconteceu! Mas a única coisa que eu não faço é pegar peso. Ela (mãe) ainda comentou isso (sobre a mãe do corpo), mas eu não senti, não senti! Mas sempre falava das dores na barriga que eu iria sentir por ser coisa de mulher, mas nem senti. Outra coisa é que eu não tenho mais aquele tempo extenso, que a gente sempre teve, mas dá pra se cuidar sim, que nem hidratante, eu uso mais nas pernas e nos braços, mas creme eu sempre usei. Agora, no pós-parto, eu já quero fazer a unha, me maquiar, cortar o cabelo, tanto que eu já tingi o cabelo, fiz um relaxamento, mas pra cortar a unha, eu demorei pra cortar a minha unha, mas faço normal (depilação) e até melhor pro corpo da mulher, na verdade, depois de mais cinco dias que eu tirei o ponto eu fui me depilar, como eu sempre me depilei. Eu comecei a me depilar novamente porque eu ainda tinha preocupação de preservar o lado feminino. Agora eu quero me cuidar, me arrumar, porque eu odeio parecer doente. Não gosto de andar de qualquer jeito, por isso, uma das únicas coisas que eu faço mesmo é usar o que eu usava antes, além de colocar brinco, prender cabelo e me arrumar. Então, está como era antes, o que eu gosto é maquiagem. Eu gosto de passar bastante maquiagem. Por isso digo que voltei a fazer tudo normalmente, mudou alguma coisa, mas continuo me cuidando e passando creme. O uso da cinta é uma cobrança tão forte pra mulher, que eu acho desnecessário, eu não usei! Também teve o caso do chá, que eu não gosto, portanto eu não tomei nenhum. Não tomei chá e nem remédio; do mesmo jeito que eu fiquei antes dos 40 dias, eu continuei. Como eu não tive dúvida nenhuma (durante o pós-parto), eu continuo me cuidando do mesmo jeito, assim, com certo cuidado, mas continuo me cuidando. $\mathrm{Na}$ verdade, a gente (puérpera e marido) não mudou muita coisa (durante o pós-parto), a gente continuou sempre no mesmo ritmo. Tanto que eu fiquei bastante tempo andando porque se eu ficasse só de repouso iria demorar pro corpo voltar! Quanto 
ao resguardo sexual, mesmo tentando manter, eu continuei tomando (anticoncepcional), usando a camisinha porque homem não agüenta, portanto, até os trinta dias, eu segui certinho! Outra coisa que eu realmente acho que tem é esse negócio do olho gordo, mas eu não acho que simpatia ajuda, então, eu não fiz e nem faço. O que eu procuro fazer é evitar o contato com as pessoas que eu sei que vão colocar alguma inveja em mim e nele (bebê).

Com a finalização da apresentação dos dados, a seguir, os confrontaremos com estudos encontrados na literatura. 


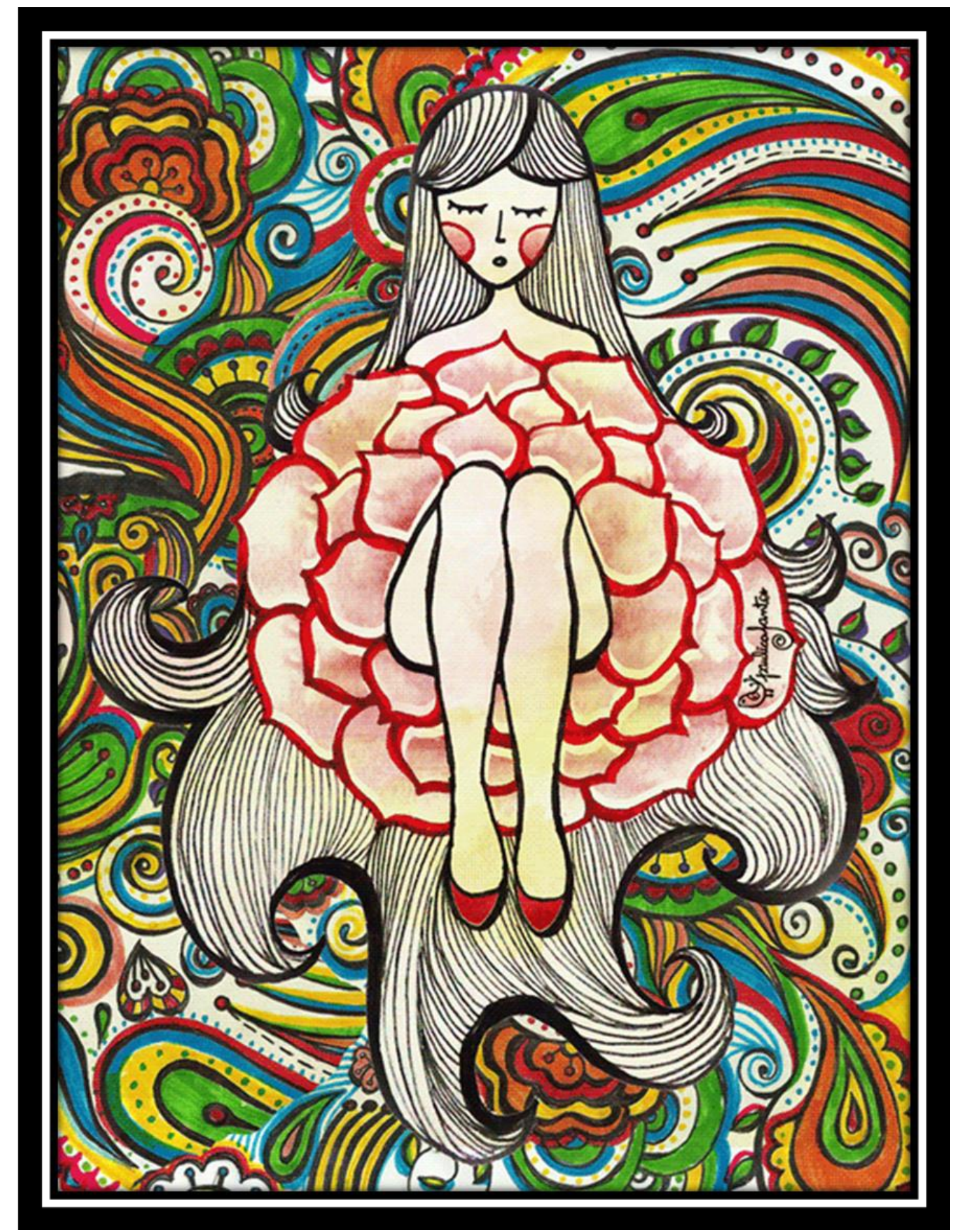

Fonte: http://paulicasantos.wordpress.com/

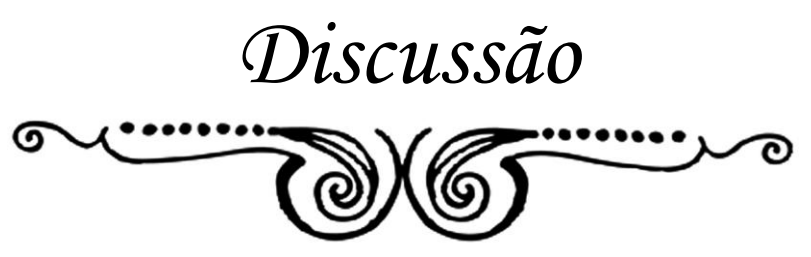


Frente aos dados sociodemográficos, neste estudo encontramos puérperas com idade entre 18 e 32 anos, assim como encontrado no estudo de Alves et al. (2007), no qual puérperas entrevistadas sobre a transição para o papel materno e assistidas em uma maternidade filantrópica de Curitiba (PR) apresentaram idade entre 20 e 30 anos. Outro estudo, realizado por Vieira et al. (2010) com puérperas multíparas atendidas pelas equipes da Estratégia Saúde da Família na área leste de Goiânia (GO), teve sujeitos com idades semelhantes às encontradas nesta pesquisa.

Ao considerarmos a média de idade das entrevistadas, de 22 anos, e ao confrontarmos com a idade média de fecundidade no estado de São Paulo, que aumentou de 26, 4 em 2000 para 27,1 anos em 2009, verificamos que, neste estudo, a média de idade encontrada foi inferior à verificada no estado (Noale, 2011). No entanto, dados do Instituto Brasileiro de Geografia e Estatística (IBGE), de 2006, mostraram a taxa de $51,4 \%$ de nascidos vivos de mães entre 20 e 24 anos para o território nacional, conforme o SINASC, o que situa as puérperas deste estudo no intervalo correspondente (IBGE, 2009b).

Estudo realizado por Monteiro (2011), com 100 puérperas internadas no alojamento conjunto de um hospital maternidade em Fortaleza (CE), constatou que essas mães tinham entre 25 e 31 anos e demonstravam maior consciência sobre o risco de adoecer; por conta disso, buscaram prevenir intercorrências no pós-parto ao colaborar e pensar na própria saúde. A par disso, tais puérperas foram representadas por uma escolaridade mais elevada, pois, no mínimo, tinham concluído o ensino médio, o que mostra semelhanças com os dados escolares encontrados neste estudo. Tal achado pode sugerir maior responsabilidade materna com as práticas de cuidado no pós-parto.

Quanto aos hábitos e vícios maternos, foi reduzido o número de puérperas (2) que disseram manter o hábito de fumar e de ingerir bebida alcoólica. Podemos comparar estes dados aos do estudo de Castro, Kac e Sicheiri (2006), que relatam também o uso do tabaco após o nascimento do bebê; e que encontraram 14,1\% de puérperas fumantes, dentre uma coorte de puérperas atendidas em um centro municipal de saúde do estado do Rio de Janeiro.

Ainda que se recomende a diminuição do consumo alcoólico durante o pósparto, o estudo citado anteriormente, demonstrou que as nutrizes aumentaram a 
ingesta de cerveja, vinho e álcool nesse período, embora nossos achados demonstrem que apenas uma puérpera referiu consumir cerveja, no mínimo, uma vez por semana (Castro, Kac, Sicheiri, 2006).

O baixo consumo de álcool e tabaco evidenciado neste estudo pode ser consequência da idade das mulheres, que, por serem adultas jovens, já ultrapassaram a fase da adolescência, grupo com maior representatividade como usuário de álcool, drogas e tabaco. Outra explicação seria a maior preocupação em evitar os riscos à própria saúde e à do recém-nascido (Kassar et al., 2006).

Quanto à escolaridade, 15 dentre as 20 puérperas concluíram o ensino médio, 1 tinha ensino superior completo e 1 incompleto, enquanto 3 tinham o ensino médio incompleto. Esses dados educacionais mostram um baixo nível de abandono escolar, que se caracterizaria no nível de ensino incompleto. Segundo o Ministério da Educação (MEC), o índice de abandono escolar em 2010, no município de Rio Claro, foi de 2,5\% para o ensino médio. Assim, verificamos o satisfatório nível de escolaridade da amostra deste estudo (Todos pela educação, 2011).

A renda familiar mensal das participantes girou em torno dos 2.120,55 reais. Dentre as 18 puérperas que apresentaram sua renda familiar, concluimos que a renda per capita estava em torno de 456, 94 reais. Pela classificação econômica da classe média brasileira, essas mulheres e suas famílias se inserem na média classe média, nA qual os indivíduos têm renda per capita entre 441 e 641 reais (Pedroso, 2012).

Salientamos também que no município de Rio Claro, em 2000, encontraramse 2,3SM (valor bruto de 347,30 reais) de renda per capita, segundo dados fornecidos pelo IBGE (SEADE, 2012).

Todavia, a maior parte das entrevistadas salientou residir com o companheiro e outros parentes, o que definiria uma relação de famílias mistas (Helman, 2009).

Vale ressaltar que não há uma definição conceitual única sobre a constituição familiar, devido às diferentes estruturas sociais e culturais na formação de uma família. Tanto é que outros tipos de famílias são concebidos, desde as nucleares, tradicionais com a formação dos papéis da mãe, do pai e dos filhos, até as famílias mistas, nos quais existe ligação entre os pais, os irmãos e os companheiros, assim como famílias compostas apenas por mãe ou pai e pelo filho (Helman, 2009). 
Segundo Kitzinger (1978), as sociedades urbanas advindas após a industrialização formaram famílias mais reduzidas, que tendem a ser nucleares e com poucos membros, devido à distância entre o campo e a cidade; com isso, a rede de parentes acaba dispersa, apenas se reunindo em momentos ritualísticos, como o nascimento ou morte de algum membro.

Verificamos que após o nascimento do bebê, em algumas situações, houve alteração do meio de transporte empregado pela puérpera, com o intuito de facilitar seu acesso à unidade de saúde. Sendo assim, ao identificarmos os meios de transporte utilizados pelas puérperas, foi pretendido associá-los à qualidade de vida, uma vez que o transporte, assim como os índices socioeconômicos e o suporte emocional e cultural, são situações que ajudam a determinar a qualidade de vida do indivíduo, conforme exposto por Aragaki e Silva (2011).

Dentre as 20 puérperas desta pesquisa, 18 mostraram seguir alguma religião. Dados semelhantes foram encontrados em estudo realizado em Curitiba (PR) por Alves (2007), no qual apenas 1 de 11 puérperas não possuía religião; relativamente semelhante ao índice de agnósticas deste estudo.

Um estudo epidemiológico, realizado na região da Grande Vitória $\left(\mathrm{ES}_{1}\right)$ com puérperas internadas em maternidades públicas, evidenciou baixa correlação entre os dados obtidos pelo cartão de pré-natal e os dados fornecidos pela mulher, uma vez que a mulher superestimava o número de consultas e cuidados recebidos (Neto et al., 2012). A média de consultas de pré-natal referidas pelas puérperas deste estudo foi de 9 consultas. Podemos dizer que ainda que tenham sido também superestimadas, todavia, encontram-se acima do recomendado pelo Ministério da Saúde, que considera o mínimo de 6 consultas para caracterizar um pré-natal eficaz (Brasil, 2002).

Devemos considerar que, no intervalo entre 2000 e 2009, houve aumento na escolaridade da população brasileira, com a consequente elevação das taxas de frequencia ao pré-natal (Domingues et al., 2012). A escolaridade mais elevada e a consciência da importância do pré-natal poderiam justificar o número de consultas citado pelas puérperas deste estudo. Vale ressaltar que quanto maior a adesão ao prénatal, maior a possibilidade de retorno para consulta puerperal com até 42 dias de pós-parto (Brasil, 2000). 
Um dado que nos chamou a atenção relacionou-se à via de parto das mulheres que participaram deste estudo. Ainda que a Organização Mundial de Saúde (OMS) preconize a margem de $15 \%$ de cesariana para população de baixo risco obstétrico, encontramos disparidades na manutenção desta taxa em Rio Claro, uma vez que a maioria das puérperas (14 em 20) foi submetida à cesariana, o que mostra o predomínio deste tipo de parto em primíparas que realizaram o pré-natal em uma UBS e, portanto, não foram consideradas de alto risco obstétrico. Cabe dizer que as taxas de cesarianas acima de $40 \%$ são consideradas elevadas e remetem a serviços de saúde que têm demanda de parturientes com alto risco obstétrico (Silva, Surita, 2009).

A porcentagem de parto cesariana encontrada neste estudo é superior ao percentual nacional que, na região sudeste, é mais elevada que $40 \%$, sendo, portanto, superior ao recomendado pela OMS. A cesariana, por ser uma cirurgia considerada de média a alta complexidade, pode gerar problemas no pós-parto, devido à pior e mais demorada recuperação da mulher. Soma-se a isso o fato de que a mortalidade por cesariana é 3,5 vezes maior do que à do parto vaginal natural, segundo Daphne Rattner, técnica responsável pelo Programa Nacional de Saúde da Mulher do Ministério da Saúde, em entrevista divulgada no site do Ministério da Saúde (Portal da saúde, 2012).

Vale salientar que estudo realizado em um hospital universitário de Goiânia (GO), citado anteriormente, encontrou taxas de 65\% de cesárea, o que se assemelha à encontrada nesta pesquisa; no entanto, tais taxas são esperadas no sistema de saúde suplementar (Vieira et al., 2010). Por outro lado, estudo realizado em Ribeirão Preto, interior de São Paulo e cidade próxima a Rio Claro, mostrou que 68\% dentre as puérperas atendidas em uma instituição filantrópica daquela cidade foram submetidas a parto normal, o que se aproxima do recomendado pela OMS (Silva et al., 2009).

As puérperas denominam o período pós-parto por vários termos, os quais assemelham-se aos encontrados nos estudos de Costa (2001), Stefanello (2005), Evans (2010) e Kalinowski (2011): resguardo, dieta e quarentena, dentre eles.

Frente os dados emanados das entrevistas, verifica-se em primeira instância o padrão da dieta alimentar adotado pelas puérperas, com abordagem sobre alimentos que devem ser ingeridos ou evitados. Notamos que foram citados o aumento da 
ingesta calórica, a melhora da qualidade da alimentação em prol do recém-nascido, a utilização de chás e o uso de lactogogos como benefício ao aleitamento materno.

$\mathrm{O}$ ato de se alimentar vai além da questão fisiológica e nutricional, pois é gerado no contexto cultural, com crenças e representações imaginárias relativas à ação dos alimentos sobre o organismo, em especial, em algumas fases do curso da vida, que, nas mulheres, correspondem à menarca, à gestação, ao puerpério e à menopausa. Embora essas fases determinem, na comunidade cultural, a necessidade de uma alimentação específica, a literatura científica orienta para a manutenção de uma dieta balanceada e com horários controlados (Canesqui, 2007; Rego, Lopes, Ventura, 2008; Baião, Deslandes, 2010; Marques et al., 2011).

No pós-parto, o aumento na ingesta calórica materna tem o intuito de produzir energia suficiente para seu organismo e para produção láctea. Tal prática é gerada pela crença disseminada pelos cuidadores culturais e pelas puérperas que, ao aumentar o consumo de alimentos, beneficiaria tanto a amamentação como o restabelecimento materno, livrando-a da inapetência e recobrando a saúde (Vàsquez et al., 2004; Raven et al., 2007; Rego, Lopes, Ventura, 2008; Lundberg, Thu, 2011).

Uma recomendação atendida corresponde ao aumento da ingesta líquida, devido à necessidade fisiológica para produção do leite, que gera na puérpera a sensação de sede. Os dados mostraram que as puérperas buscaram a alimentação mais regrada, tanto nos horários mais rígidos como na qualidade e na seleção de alimentos de boa qualidade. Na literatura, todos os alimentos da pirâmide alimentar são indicados na fase pós-parto, com destaque para carnes, verduras, legumes e frutas, com controle, como em qualquer dieta, de açúcares, gorduras e farinha branca (Rego, Lopes, Ventura, 2008; Marques et al., 2011).

A par desta situação, os dados mostraram que as puérperas preferem alimentos que agem como fontes de vitaminas. Uma alimentação semelhante foi encontrada em estudo realizado com 80 puérperas, que tiveram parto hospitalar na região de Foz do Iguaçu (PR), o qual informa que, além dos alimentos citados, as puérperas ainda faziam uso da lentilha, por a considerarem uma fonte de energia necessária no pós-parto (Rigo, Neves, 2011). Tais alimentos são destacados como necessários à dieta materna, pois são fontes de energia, proteína e ferro. Alguns 
alimentos recebem a designação de serem "fortes", pois são ricos em vitaminas necessárias ao período puerperal, como visto no estudo de Marques et al. (2011).

Os cuidados com a escolha alimentar indicam valores socioculturais sobre a concepção dos benefícios e dos malefícios dos alimentos. Frente a isso, verificamos que para a puérpera, a banana ingerida no pós-parto se constitui em fonte de vitamina que ajuda a combater a anemia materna e do recém-nascido. No entanto, contrário à este achado, para as mulheres da cultura Hmong, advinda da Austrália, a banana, assim como as demais frutas doces, devem ser evitadas por causar danos à saúde durante esse novo estado do organismo, ou seja, o período pós-parto (Rice, 2000; Baião, Deslandes, 2006; Canesqui, 2007).

A alimentação materna pode interferir indiretamente no organismo do recémnascido, segundo os achados deste estudo, pois as puérperas demonstraram acreditar que todos os alimentos ingeridos passam para o leite e, consequentemente, para o recém-nascido, daí as privações e as indicações de alimentos para a nova mãe. Essa condição encontra respaldo em algumas culturas nas quais se crê que a composição da alimentação materna poderia gerar alterações no sabor do leite materno, levando o recém-nascido ao desmame. Para evitar essa situação, condimentos e temperos fortes, como o alho, deveriam ser evitados (Vaucher, Durman, 2005; Marques et al., 2011; Rigo, Neves, 2011).

A influência da alimentação materna sobre o concepto é altamente visível neste grupo de puérperas, que relataram sua dieta conforme os hábitos intestinais do recém-nascido. Sob este aspecto, um estudo etnográfico realizado na Colômbia, nas cidades de Cali e Bogotá, mostrou que alimentos gasosos, como as bebidas com gás, podem gerar desde vômitos até acúmulo de gases ou diarreia no bebê (Vásquez et al., 2004). Outro estudo, dirigido por Osman, Zein e Wick (2009), com puérperas de 17 instituições hospitalares libanesas, encontrou que comer repolho, couve-flor e uma espécie de espinafre poderia causar no recém-nascido desde retenção de gases até diarreia.

Nos casos de constipação materna, esperada no período pós-parto devido ao processo de involução gravídica, é comum a insegurança nas puérperas, pois, culturalmente, se o intestino não se regularizar durante o puerpério, o hábito intestinal permanece irregular por toda a vida ou até o próximo período de puerpério. 
Por isso, foram incentivadas pelos cuidadores familiares e culturais a aumentar a alimentação com fibras, aveia e alimentos que contribuem para a motilidade intestinal, a fim de ajudar na evacuação. Dados semelhantes sobre a alimentação para a regularização do trato intestinal foram verificados nos estudos de Farias (2008), Vieira et al. (2010) e Marques et al. (2011), demonstrando que é comum as puérperas apresentarem temores sobre o retorno da regularidade intestinal durante o período do pós-parto.

Por ser tão semelhante quanto ao sono para a recuperação e estabelecimento da saúde, a alimentação sofre interferências sociais e culturais (Canesqui, 2007).

Essa avaliação cultural sobre a dieta materna gerou o corte, por algumas puérperas, de alguns alimentos da dieta, como o tomate, que, culturalmente, é considerado extremamente ácido; sendo assim deveria ser evitado, pois poderia causar desconforto abdominal no recém-nascido. Ainda que no estudo quantitativo realizado com 92 doadoras de banco de leite, na cidade de Sorocaba (SP), não tenha se encontrado correlação entre acidez do leite humano e alimentação, a influência cultural dos membros mais antigos e experientes da comunidade direcionou para que certos alimentos ainda hoje sejam evitados; fato observado e respeitado por esta população (Baião, Deslandes, 2006; Canesqui, 2007; Scarso, Porto, CanniattiBrazaca, 2009; Marques et al., 2011).

Os alimentos são classificados quanto à composição nutricional, de acordo com a cultura e a sociedade onde a pessoa está inserida. Além disso, o estudo dos hábitos alimentares classifica os alimentos como profanos, remosos, gordurosos e ácidos, muitas vezes independente da composição destes, mas levando em consideração o estado do indivíduo que irá recebê-lo (Chamilco, 2004; Baião, Deslandes, 2006; Canesqui, 2007; Helman, 2009; Baião, Deslandes, 2010).

Da mesma maneira, as mulheres apresentaram motivos e percepções que determinaram a adesão à determinada dieta, assim como mostraram a classificação dos alimentos como ácidos, gasosos, cítricos, vitaminados e até neutros, além dos efeitos sobre o organismo materno e do recém-nascido.

A acidificação do leite pela alimentação materna poderia gerar alterações na eficácia de alguns de seus nutrientes (Novak, Cordeiro, 2007). No entanto, estudo que analisou a dieta de 32 doadoras de leite para um banco de leite humano no 
município de Sorocaba (SP), não verificou correlação entre a acidez e a alimentação e concluiu que uma acidificação é esperada e poderia não prejudicar o recém-nascido (Scarso, Porto, Canniatti-Brazaca, 2009).

O vinagre, por ser ácido e considerado "forte", afetaria o recém-nascido, causando cólica; entretanto, na cultura vietnamita, para o resguardo ${ }^{1}$ e $\mathrm{o}$ restabelecimento do calor corpóreo materno, são ingeridos tanto o gengibre como o vinho, que também teria acetato na fórmula; portanto, considerado ácido; no entanto, para aquela cultura, não é descartado (Stefanello, 2005; Stefanello, Nakano, Gomes, 2008; Lundberg, Thu, 2011).

Os dados deste estudo mostraram que as puérperas disseram evitar alguns alimentos pensando no bem-estar próprio e também do filho, sendo os mais frequentes citados: refrigerante, doces, alimentos ácidos, como algumas frutas e verduras, molho de tomate, embutidos, queijo e café.

Os refrigerantes e os doces eram evitados, pois, segundo as puérperas geravam gases, tanto nelas como no recém-nascido, por isso, ao retirá-los da dieta, a puérpera e o bebê não tinham necessidade de ingerir medicamentos antiespasmódicos. Dados similares são vistos nos estudos de Costa (2001), Stefanello (2005) e Stefanello, Nakano e Gomes (2008), nos quais foram evitados alimentos doces e gaseificados com o intuito de reduzir as cólicas intestinais, em especial, do bebê.

Ademais, os alimentos classificados como ácidos e gasosos poderiam gerar danos ao intestino do bebê, como acúmulo de gases; daí, deveriam ser evitados ao máximo durante a amamentação, como visto nos estudos de Stefanello (2005), Stefanello, Nakano e Gomes (2008) e Marques et al. (2011).

Além disso, os alimentos com propriedades cítricas poderiam gerar alterações no paladar do leite e também prejudicar a cicatrização da sutura materna, uma vez que poderiam gerar processo inflamatório nos pontos, conforme evidenciado nos

\footnotetext{
${ }^{1}$ Resguardo: Segundo Weiszflog (2007), resguardo tem como definição fase de cuidado, precaução e dieta, ainda, a expressão "em resguardo" correlaciona-se a dieta e cuidados à saúde, em especial, após o parto. Para as participantes do estudo de Costa (2001), resguardo significa o repouso de até 30 dias após o parto, além disso, traz a conotação de obediência aos cuidados para que não fique doente, ou seja, não tenha recaída. No estudo de Stefanello (2005), o resguardo tem a conotação de uma fase que a mulher deveria ter o cuidado redobrado para se recuperar do parto, assim como compartilhado por Nakano et al. (2003), que reafirma que as restrições almejam o reestabelecimento puerperal.
} 
estudos de Stefanello (2005), Canesqui (2007), Stefanello, Nakano e Gomes (2008) e Rigo e Neves (2011).

Paradoxalmente, as nutrizes passam a ter alimentação mais saudável após o parto, preferindo comer em maior quantidade frutas e verduras e evitando gordura (Sandre-Pereira et al., 2000). No entanto, verificamos nos DSC que as puérperas tinham receio de ingerir sucos de frutas cítricas, pois a influência cultural predizia que tal alimentação poderia gerar inflamação da sutura, no corpo materno, e gases no recém-nascido.

Cabe-nos ressaltar que a preocupação com a alteração do gosto do leite materno não foi evidenciada nos DSC, entretanto, o ovo, a carne de porco e o peixe foram retirados da dieta puerperal, pois a mulher os via como riscos à cicatrização materna, assim como as frutas cítricas.

No presente estudo, as puérperas tiveram atitudes para a proteção contra a "friagem" e uma delas foi a exclusão da dieta de alguns alimentos gelados, como sorvetes e água fria, o que é concordante com os achados do estudo de Vásquez et al. (2004); estudo no qual registrou-se que as puérperas dessa cultura evitaram os alimentos frios, uma vez que o organismo feminino está "aberto" após o parto e poderia gerar o adoecimento da mulher devido a entrada de friagem ${ }^{2}$ advinda desse tipo de alimento.

Para as puérperas Hmong entrevistadas em uma pesquisa etnográfica realizada na Austrália, o sorvete e a água gelada, se ingeridos, gerariam coagulação sanguínea excessiva e levariam a mulher à morte. Além disso, e conforme esta pesquisa, as mulheres diminuíam ou evitavam frutas ácidas, vistas como "geladas", pois levariam a quadros de tosse, asma e resfriados, a longo prazo, na vida materna (Rice, 2000).

Segundo a revisão da literatura, no pós-parto são indicados alimentos com alta temperatura, ou seja, quentes que, segundo a teoria humoral, ajudariam tanto na melhor circulação sanguínea como na eliminação dos lóquios (Lundberg, Thu, 2011).

Em algumas regiões e comunidades brasileiras, ser "quente" se refere a alimentos que aumentam a temperatura corpórea interna, mas geram malefícios para

\footnotetext{
${ }^{2}$ Friagem: Tem como uma das definições: Ar frio (Weiszflog, 2007). No presente estudo, o termo friagem esteve relacionado à manutenção do padrão quente e frio no organismo materno, uma vez que a entrada desta no organismo causaria adoecimento, como também observado no estudo de Kalinowski (2011).
} 
o recém-nascido, daí evitar o chocolate, a pimenta e o peixe, sendo este último considerado "reimoso", ou seja, "pesado", segundo a classificação do organismo da pessoa que o irá receber (Baião, Deslandes, 2006; Canesqui, 2007).

Vale salientar que cada cultura determina criações simbólicas próprias de cada alimento, que podem diferir segundo a região de ocorrência do evento. Um exemplo ocorre com as vietnamitas internadas em um hospital universitário, para as quais a carne de porco ingerida com mamão é indicada no pós-parto, por pelo menos 2 meses, pois incentiva o aleitamento; versão que em outras culturas não é sustentada, pois o porco seria considerado um alimento reimoso, que prejudica a cicatrização das suturas (Stefanello, 2005; Baião, Deslandes, 2006; Canesqui, 2007; Stefanello, Nakano, Gomes, 2008; Marques et al., 2011; Marques et al., 2011; Lundberg, Thu, 2011).

Quanto à ingestão da carne de porco, alguns profissionais a contraindicam, pois acreditam interferir na cicatrização das suturas, mesmo sem evidências para comprovar tal recomendação. Não obstante, a carne de porco deve ser evitada por ser gordurosa e reimosa (Costa, 2001; Stefanello, 2005; Stefanello, Nakano, Gomes, 2008; Vieira et al., 2010; Marques et al., 2011; Rigo, Neves, 2011).

Além das restrições aos alimentos citados, os DSC mostraram que as puérperas evitaram e diminuíram a ingestão de alimentos fritos, hambúrguer, bacon e salgadinhos.

Vale salientar que, neste estudo, mesmo dando preferência para carnes branca e vermelha, alguns familiares das puérperas destacaram que o consumo excessivo de carne vermelha poderia acumular ferro e gerar danos à saúde materna. Justifica-se esta situação com dados da literatura que mostram culturas nas quais a carne de gado é considerada "forte" para o estado puerperal (Canesqui, 2007).

Considerando as restrições, as puérperas deste estudo salientaram que deram preferência pela alimentação saudável, baseada em frutas, legumes cozidos, verduras, cereais, carne branca e sopas. Para elas, a carne branca foi a mais utilizada, ou seja, o frango, pois acreditavam que não seria gordurosa ou reimosa e, portanto, não afetaria

\footnotetext{
${ }^{3}$ Reimoso: Tem como definições: O que tem reima ou reuma; cheio de humores, faz mal ao sangue, ainda pode gerar prurido (Weiszflog, 2007). Sendo assim, o melhor conceito que define este termo no estudo seria o fato de fazer mal ao sangue. Nos estudos de Canesqui (2007) e Rodrigues (2001), a reima está associada ao sangue e sinaliza os prejuízos causados neste humor por isso deveria ser evitada pelas pessoas convalescentes, em especial pelas mulheres em períodos especiais, como o ciclo gravídico-puerperal, por ter conotação prejudicial à saúde. Ainda, em diferentes regiões brasileiras, a reima pode ser identificada por "carregado", principalmente nas regiões sul e sudeste.
} 
a cicatrização; dados também encontrados em estudos de Costa (2001), Vásquez et al. (2004), Stefanello (2005), Vaucher e Durman (2005), Stefanello, Nakano e Gomes (2008), Baião e Deslandes (2010), Vieira et al. (2010), Kalinowski (2011), Marques et al. (2011) e Rigo e Neves (2011), que envolveram a alimentação materna no pós-parto e evidenciaram que a carne de boi, porco ou peixe seria prejudicial à nutriz.

Outras culturas recomendam que a nutriz ingira carne vermelha e alimentos ricos em proteínas, como o ovo, pois, mesmo sendo considerados "fortes", poderiam ajudar na recuperação mais rápida no pós-parto, além de contribuir para minimizar as anemias fisiológicas geradas tanto pelo reservatório de ferro para os fetos como pela perda de sangue no parto. Tais alimentos auxiliariam também diante das perdas pelos lóquios e na estimulação da produção de leite materno (Raven et al., 2007).

Para as peruanas de comunidades nativas Awajun y Wampis, após o parto, as mulheres não poderiam ingerir carne de veado, nem fígado e intestino de animais e peixes, por acreditarem que são alimentos que geram diarreia no recém-nascido. Para adolescentes colombianas, os cuidados culturais indicavam que evitassem os alimentos "frios", com a conotação que dariam cólica no bebê, e que excluíssem da dieta materna carne de porco cozida, saladas e alimentos gasosos, pois inflamariam o útero e também contribuiriam para o retardo da cicatrização (Vásquez et al., 2004; Medina, Mayca, 2006).

Sendo assim, a influência cultural é fortemente arraigada nos cuidados com a puérpera em nível global. Prova disso, estudo da década de 1980, realizado com população de área rural da Coreia, evidenciou que as puérperas não poderiam ingerir qualquer tipo de alimento, pois os difíceis de mastigar poderiam gerar queda dentária, pela fraqueza dos dentes no período pós-natal (Sich, 1981).

Vale salientar que o cuidado com a nutrição da puérpera que amamenta é tradição milenar e segue o processo familiar intergeracional, buscando aprimorar o cuidado da mãe e do bebê (Marques et al., 2011; Lundberg, Thu, 2011).

Sendo assim, cabe-nos destacar que os alimentos "fortes", como a carne de porco e o ovo, relacionaram-se à mudança do odor do leite materno, o que poderia influenciar o paladar do recém-nascido. Estudos também demonstraram que os alimentos "gordurosos" e "pesados" poderiam desconfigurar o gosto do leite 
materno, desestimulando a amamentação (Vaucher, Durman, 2005; Rigo, Neves, 2011).

Os dados obtidos também mostraram que houve aumento na ingesta hídrica da puérpera devido à amamentação, o que colaborou para a dieta baseada em caldos e/ou sopas. Dados similares foram encontrados em diferentes populações no território brasileiro, conforme estudos de Kalinowski (2011), Marques et al. (2011), Monteiro (2011) e Rigo e Neves (2011), que demonstraram a preferência das mulheres por líquidos.

Enquanto frutas e vegetais, em especial, cozidos, eram incentivados para ingestão pelas puérperas deste estudo, para as entrevistadas da pesquisa de Raven et al. (2007) tais alimentos deveriam ser evitados, por serem considerados, pela população de chinesas atendidas em um hospital materno-infantil na província chinesa de Fujiian, como alimentos "frios", daí, na área rural investigada, mais de $50 \%$ das participantes relatarem não ingeri-los por recomendação de familiares, tais como as avós.

$\mathrm{Na}$ literatura, encontramos, também, estudo realizado com parteiras da região da Amazônia Legal, que identificou que as puérperas atendidas por elas eram desestimuladas a ingerir alimentos requentados e café, pois poderiam gerar desde desconforto abdominal até infecções (Chamilco, 2004).

No caso das 300 mulheres da Vila de Danbare, no norte da Nigéria, a cultura local incentivava-as a comer mingau enriquecido com sal da região para $o$ restabelecimento materno ser mais rápido (Iliyasu et al., 2006).

Os dados mostraram a preferência das puérperas deste estudo pela soja em substituição ao leite, pois, para algumas delas, o leite de vaca poderia ser muito gorduroso e afetaria a cicatrização e a recuperação materna, além de referirem que o leite adoçado com açúcar causava cólica no recém-nascido. Estudo randomizado com 302 mulheres das áreas urbana e rural da China também encontrou preferência por produtos à base de soja, vegetais e frutas pela população urbana estudada. Dados semelhantes foram verificados na região de Paulínia, interior de São Paulo, onde o leite seria considerado "forte" para ser ingerido no puerpério (Canesqui, 2007; Liu et al., 2009). 
A par da predileção pela soja por algumas mulheres, o leite ainda continua sendo o alimento preferido pelas puérperas e familiares, por ser altamente lactogênico, segundo representações simbólicas e culturais. Além deste alimento, as sopas, os caldos e a canja eram ingeridos tanto para o restabelecimento materno após o parto como para melhorar a qualidade do leite. Neste estudo, além destes alimentos, foi relatado também o aumento da ingesta hídrica, ingesta de pirão de galinha caipira, da água na qual a canjica ficou mergulhada, do milho e da rapadura. Achados que mostram relações culturais próximas entre as puérperas investigadas e aquelas de estudos dirigidos por Vieira et al. (2010), Marques et al. (2011) e Rigo e Neves (2011), o que nos permite identificar semelhanças alimentares entre puérperas de diferentes regiões do Brasil.

Vale salientar que os lactogogos são fielmente incorporados às crenças maternas por algumas mulheres, tanto deste estudo como nos de Argote e Vásquez (2005), Baião e Deslandes (2006), Canesqui (2007), Marques et al. (2011) e Rigo e Neves (2011); entretanto, algumas mulheres apenas replicam o conhecimento adquirido nas redes de contato, não tendo conhecimento aprofundado sobre o assunto. Isso ocorre, pois as puérperas, tanto deste estudo como dos demais citados anteriormente, recebem atenção tanto do profissional de saúde como de seu contexto familiar e social e, muitas vezes, a falta de diálogo entre ambos os saberes e a nova mãe gera conflitos frente aos conhecimentos apreendidos, situação que pode gerar práticas replicadas passivamente, como regras, e não conhecimentos adquiridos.

Os lactogogos, alimentos que ajudam a gerar o leite materno, foram fortemente indicados para as puérperas; com isso, as novas mães incorporaram na dieta maior quantidade de leite, suco de frutas e líquidos. Além disso, as puérperas que não utilizavam a bebida da soja buscaram aumentar a ingesta de leite com a finalidade de aumentar sua produção; é como se os nutrientes do leite ingerido produzissem seu próprio leite. Caso as puérperas não ingerissem alimentos lactogênicos, nem leite, o leite materno poderia ser "fraco" ou até "ralo", dado também encontrado nos estudos de Vaucher e Durman (2005), Vieira et al. (2010) e Marques et al. (2011), que demonstraram aspectos semelhantes em diferentes populações. Abordaremos este tema com maior detalhamento mais adiante. 
A influência dos lactogênicos é tão forte sobre as puérperas que $76 \%$ das 80 entrevistadas em Foz do Iguaçu (PR) revelaram que já utilizaram alguma receita ou alimentação para aumentar a qualidade e a quantidade do leite materno (Rigo, Neves, 2011).

As puérperas relataram, ainda, que ingeriram chá, com o intuito de diminuir o nervosismo materno para que mais leite fosse produzido, além de contribuir para o relaxamento do recém-nascido. $\mathrm{O}$ uso do chá pelas colombianas, relatado em estudo citado anteriormente, ajuda a mulher a manter o corpo aquecido e não gerar cólica no binômio mãe-bebê, pois evita a entrada de alimentos frios, que resfriam o organismo da mulher e geram problemas de saúde (Vásquez et al., 2004). Outro estudo, sobre os Criollos do Chaco argentino e a utilização de ervas medicinais, mostrou que, naquela região, por meio da infusão de algumas plantas específicas, são retirados o "susto" ou "mau olhado" que geram irritabilidade, inapetência e choro excessivo no bebê (Scarpa, 2003).

Segundo a Organização Mundial da Saúde, a alimentação materna pouco interferiria na composição do leite e no organismo do recém-nascido (Akré, 1994). No entanto, para a comunidade chinesa da província de Fujian, o déficit alimentar poderia manter o organismo materno fragilizado enquanto, para os cuidadores biomédicos e tradicionais, da mesma região, o aumento da ingesta calórica deve ser controlado, caso contrário contribuiria para a obesidade (Raven et al., 2007).

Para as puérperas, o retorno do padrão alimentar semelhante ao período prégravídico, ao término do pós-parto, ocorreu, em geral, ao fim dos 40 dias; entretanto, algumas mulheres salientaram esperar mais tempo, em torno de 3 a 6 meses de vida da criança. Cuidar da ingesta calórica sempre foi uma preocupação materna, pois tanto a rede de contato como os profissionais selecionam os alimentos desde o prénatal por conta dos malefícios para o concepto. No pós-parto, esse conceito é mantido devido ao aleitamento. Por isso, tanto a gestante como a puérpera devem ser cuidadas quanto aos aspectos nutricionais desde a gestação, perpassando pela fase de amamentação (Brasil, 2000; Monteiro, 2011).

Devemos contextualizar as crenças, os valores, os mitos e os tabus frente à alimentação das mulheres, em especial durante o puerpério, pois muitas são as restrições culturais e sociais encontradas nesse período. Sendo assim, os profissionais 
da área da saúde e os cuidadores culturais devem entender e respeitar a decisão da puérpera frente às fontes de obtenção de energia, ou seja, os alimentos. Por meio do cuidado culturalmente competente, ao respeitar os preceitos maternos, o profissional, em consonância com a puérpera, pode definir qual o melhor padrão alimentar para seu estado geral, levando em consideração os padrões ditados pela cultura e sociedade (Purnell, 2000).

$$
* * *
$$

Vale salientar, que a maior parte dos dados coletados por meio das entrevistas gerou a construção dos discursos que se enquadraram no domínio Práticas, valores e crenças no puerpério, uma vez que envolviam a vivência biossociocultural da puérpera em suas práticas de cuidado.

Os DSC trataram do tempo do pós-parto, das restrições para que não ocorresse a "recaída" ${ }^{4}$ " e da fragilidade na saúde da puérpera, além de cuidados com o encerramento do puerpério e a finalização deste ritual, com a finalidade de recuperação da saúde da mulher, evitando esforços físicos.

Segundo o Programa de Humanização do Parto e Nascimento, do Ministério da Saúde, o puerpério equivale aos 42 dias após o parto; entretanto, para alguns estudiosos, o término corresponde ao período de 42 a 56 dias de pós-parto, no qual a regressão gravídica seria finalizada (Cunningham et al., 2000; Neme, 2000; Costa, 2001; Brasil, 2002).

Vimos que as redes de contato da puérpera e sua cultura influenciaram-na e geraram diferentes períodos de duração da fase pós-parto. Ainda que as puérperas acreditassem que o cuidado deve permanecer até os 40 dias exatos de pós-parto, muitas salientaram ouvir de terceiros que este período se estendia conforme o gênero do recém-nascido.

Alguns autores, assim como manuais de saúde, sugerem que o puerpério se inicia uma hora após o término do parto e não tem fim exato, pois a regressão gravídica continuaria enquanto existisse o aleitamento materno, fato responsável por gerar modificações no corpo materno (Brasil, 2001; Souza et al., 2008).

\footnotetext{
${ }^{4}$ Recaída: Advindo do verbo recair, repetição ou agravamento de uma doença (Weiszflog, 2007). Neste estudo, o termo recaída está relacionado ao fato de adoecer sem ter se curado, ou seja, a transgressão de uma regra geraria a doença. Assim como encontrado por Stefanello, Nakano e Gomes (2008), a recaída seria um agravo na saúde e transcende a definição própria da palavra, pois indicaria que a pessoa somente seria curada se passasse pela fase do puerpério novamente e/ou jamais teria a possibilidade da cura.
} 
Para Liu et al. (2009), que consideram os aspectos socioculturais envolvidos no período pós-parto, sua duração é definida aos 30 ou 40 primeiros dias após o nascimento do bebê. Enquanto que para Vásquez et al. (2004) e Evans (2010) corresponde aos 42 dias após o parto. Para Raven et al. (2007) esse período equivale aos 30 dias após o nascimento do bebê. Portanto, assim como entre as puérperas deste estudo, não há consenso quanto à duração do puerpério entre os pesquisadores.

Verificamos que as puérperas deste estudo conhecem o puerpério como quarentena, dieta ou resguardo, confirmando os aspectos culturais envolvidos. Sendo assim, essas designações sobre o nome que este período recebe da população conotam uma fase que requer cuidado para o restabelecimento da saúde da puérpera, sem intercorrências - recaída - que provocariam na mulher, segundo sua crença, uma doença incurável e transtornos para o resto da vida (Costa, 2001; Nakano et al., 2003).

Caso a puérpera se desvie do padrão imposto por sua cultura, no qual a mãe está vulnerável e com o corpo "aberto" após o nascimento do bebê, os sentimentos de culpa e medo a dominam, daí; algumas mães preferirem seguir parcialmente o cuidado cultural, como visto nos dados dos discursos. Isso ocorre, pois se quebrarem tais regras e tabus impostos socioculturalmente poderiam sofrer recaída, espécie de infração sobrenatural à puérpera que divergiu da regra imposta (Costa, 2001; Stefanello, 2005; Stefanello, Nakano, Gomes, 2008; Waugh, 2011).

Evidenciamos nos dados coletados várias mudanças que ocorreram no cuidado puerperal, e que se assemelhavam aos encontrados no estudo de Chamilco (2004), no qual a convivência com parteiras possibilitou demonstrar vários atos e práticas dirigidas por estas profissionais, como restrições alimentares e outros cuidados prezando o restabelecimento da puérpera, para evitar recaída. Além disso, outros estudos relataram dados protetivos, referentes aos cuidados com a puérpera, gerados principalmente pelas redes de contato familiar (Sich, 1981; Costa, 2001; Vásquez et al., 2004; Stefanello, 2005; Medina, Mayca, 2006; Raven et al., 2007; Stefanello, Nakano, Gomes, 2008; Kalinowski et al., 2010; Kalinowski, 2011; Lundberg, Thu, 2011; Waugh, 2011). 
Observamos que os cuidados relacionados ao corpo materno não se dissociaram de crenças e valores que influenciam o estado de saúde materno, como apresentado por Waugh (2011).

Tais práticas de cuidados se mantêm ativas tanto na população investigada como nas puérperas estudadas por Lundberg e Thu (2011), pois o resguardo é um período de forte influência cultural, cujos cuidados são transmitidos pelos familiares do sexo feminino, que influenciam nas decisões e na conduta de cuidado da nova mãe. E esse cuidado cultural de transmissão intergeracional, em maior grau de mãe para filha, é mantido nestes 40 dias de pós-parto, com foco na recuperação da saúde materna e na manutenção do estado saudável do recém-nascido.

Essa situação mostrou-se presente em estudo realizado com 300 mães da Vila de Danbare, na Nigéria, que constatou que 93\% dessas mulheres acreditam que se não seguissem os cuidados puerperais perpassados pela sociedade e cultura nos quais se inseriam, ficariam fracas e não recuperariam o estado fisiológico anterior à gestação (Iliyasu et al., 2006).

Vale ressaltar que a literatura traz estudos com abordagem em crenças próprias da fase do puerpério. O cômputo dos achados mostra que, no puerpério, se o corpo da mulher-mãe permanecer "aberto" e ocorrer invasão de microrganismos ou o estabelecimento de alguma doença, isto implicaria que esta mulher jamais teria cura. Por conta dessa situação, muitas restrições e tabus referentes à alimentação, às vestimentas, à teoria humoral, à atividade sexual e aos cuidados com a higiene foram delimitados para proteger o corpo materno e evitar doenças (Sich, 1981; Costa, 2001; Nakano et al., 2003; Vásquez et al., 2004; Stefanello, 2005; Raven et al., 2007; Stefanello, Nakano, Gomes, 2008; Kalinowski et al., 2010; Kalinowski, 2011; Lundberg, Thu, 2011; Waugh, 2011).

Os dados mostraram também que, caso as puérperas encerrassem o puerpério com algum problema de saúde ou recaída, somente se curariam após outro parto com cuidados redobrados. Dados similares foram encontrados em outras sociedades e culturas: a puérpera chinesa que não se cuidar terá uma "pobre" saúde, ou seja, sua saúde estará prejudicada. Essas mulheres eram encorajadas pelas redes de contato a ter filhos, pois o pós-parto, quando bem resguardado, serviria para reaver a saúde que 
anteriormente não possuíam; tais práticas foram encontradas em algumas partes da China (Sich, 1981; Raven et al., 2007).

A finalização do pós-parto demanda novos cuidados culturais, uma vez que seria a última oportunidade para a cura de uma recaída. A explicação cultural está em que, com o término do puerpério, o corpo da mulher se "fecha" novamente. Por isso, se adquiriu alguma doença, e não se curou, permanecerá doente por toda a vida ou até um próximo período puerperal (Vásquez et al., 2004; Stefanello, 2005).

A teoria humoral que se relaciona à qualidade do sangue teria influência sobre a saúde corporal e sobre o funcionamento do organismo. Daí, a puérpera acreditar que quando o sangue estivesse "sujo", "espesso" ou "pesado" deveria ser "limpo" para não desencadear prejuízo ao organismo. Uma das maneiras de ajudar a restabelecer esse padrão seria com o uso de ervas, sendo a infusão o modo mais utilizado. O emprego de infusão ou chá no período pós-parto se deve, portanto, à crença de que a puérpera precisa encerrar o puerpério com o sangue depurado e limpo (Nakano et al., 2003; Vásquez et al., 2004; Stefanello, 2005; Kalinowski, 2011). Para os criollos do Chaco Argentino, plantas como Yerba, Manzanilla del campo, Suncho e Hoja redonda são usadas para distúrbios puerperais, pois ajudariam a puérpera restabelecer a saúde (Scarpa, 2003).

Por conta disso, outra prática que merece destaque e que foi identificada neste estudo relaciona-se ao último dia do puerpério, quando a puérpera deveria ingerir uma infusão de pinga com ramo de arruda, de modo a proteger-se de alguma recaída e para concluir o ciclo gravídico-puerperal com a saúde restabelecida.

Para algumas colombianas da região de Cali e Bogotá, o puerpério seria um período no qual a nova mãe deveria evitar as correntes de frio e ter uma boa alimentação, para ajudar o útero a involuir e para retirar as impurezas do sangue, além de redobrar os cuidados ao término dos 40 dias de pós-parto. Para essas puérperas, o término do puerpério exige alguns cuidados especiais, como: tomar água aromática quente ou fervida, apertar o abdômen com uma faixa para propiciar a saída das impurezas e, no último dia, acender e realizar o ritual dos incensos, para que o corpo se "feche" sem impurezas ou doenças que deixariam a mulher com a saúde deficitária (Vásquez et al., 2004). 
Dados semelhantes são relatados pelas puérperas participantes deste estudo. Para elas, os cuidados eram redobrados próximo ao final do puerpério, quando, tanto deveriam permanecer dentro de casa por mais tempo como não se expor à friagem. Tais achados são concordes com o estudo de Vásquez et al. (2004), que relatam que as puérperas colombianas, no momento de encerramento do resguardo, devem permanecer ainda mais tempo dentro de sua casa.

Ainda, o estudo qualitativo dirigido por Argote e Vásquez (2005) com 8 puérperas provenientes de Cali, Colômbia, evidenciou que para aquela população a entrada do frio no organismo materno influenciaria o recém-nascido, uma vez que receberia a friagem. Por conta disso, essas puérperas ao amamentarem deveriam cobrir os seios para que o leite não resfriasse e afetasse o recém-nascido. Dados semelhantes foram encontrados na população investigada por este estudo, no qual as puérperas procuravam não tomar friagem, pois passariam ao bebê e geraria cólica neste, além disso, aqueciam as mãos para não resfriar o recém-nascido ao tocá-lo.

Outra abordagem presente nos DSC relacionou-se à necessidade de repouso para não levantar peso nem fazer esforço. Os relatos mostraram a necessidade de permanecer na cama, com temas como: não praticar atividade física, não fazer agachamento, não realizar atividades domésticas, não andar de moto ou de bicicleta e tomar cuidado com a tosse, que poderia romper a episiorrafia.

Assim, estes achados mostraram que as puérperas tinham restrição aos serviços domésticos, em especial pelas atividades envolvendo o emprego de vassoura e rodo, tanto é que o simples fato de tocar em tais instrumentos poderia gerar quebra das regras do pós-parto e recaída imediata, que só seria excluída tomando chá de ramo de arruda para o livramento desta e o "fechamento" do corpo saudável.

Os dados obtidos apontaram que o repouso para não se esforçar está diretamente ligado à cicatrização da sutura. Dados semelhantes foram encontrados em vários estudos, realizados em algum momento do pós-parto, e que envolveu puérperas e seus cuidadores (Costa, 2001; Nakano et al., 2003; Chamilco, 2004; Stefanello, 2005; Fleischer, 2007; Farias, 2008; Stefanello, Nakano, Gomes, 2008; Kalinowski, 2011; Monteiro, 2011).

A crença relacionada ao repouso no pós-parto foi verificada, também, em população rural e urbana de uma província chinesa, cujas puérperas deveriam evitar 
trabalhos domésticos, muito embora algumas, ao final do puerpério, realizassem trabalhos leves, quando necessário; no entanto, estavam proibidas as atividades no lar relacionadas ao manuseio de água e à exposição ao vento, para evitar ser acometida pela friagem e sofrer recaída. Para a mulher vietnamita, tais atividades domésticas poderiam gerar até prolapso uterino (Raven et al., 2007; Lundberg, Thu, 2011).

Dados semelhantes foram encontrados na etnografia citada anteriormente, que investigou colombianas de Cali e Bogotá, na qual estas puérperas, além de permanecer no interior de suas casas ou quartos, não deveriam se expor aos trabalhos domésticos relacionados ao manuseio de água, devido ao resfriamento corpóreo e aos danos à saúde, uma vez que o corpo se encontrava "aberto" (Vásquez et al., 2004). Waugh (2011) acredita que tais cuidados e comportamentos relacionam-se à proteção do corpo no pós-parto.

Estudo realizado com parteiras tradicionais na região da Amazônia Legal, que levou em consideração localidades do norte e da porção centro-norte brasileira, constatou que as puérperas permaneciam no quarto por até sete dias do parto, para repouso, mas, após esses dias, estavam liberadas para fazer atividades leves, como cuidar do recém-nascido e do marido, cozinhar e até mesmo atividades domésticas, desde que não exigissem extravagâncias (Chamilco, 2004). Semelhanças foram encontradas neste estudo, uma vez que as puérperas citaram que somente poderiam cuidar do bebê após a queda dos pontos e que as atividades deveriam ser leves, como, por exemplo, cozinhar.

As mulheres que vivenciavam o pós-parto nos estudos de Pedroso (1982), Pinelli (1988), Boehs et al. (1993) relatavam que após um período de descanso em torno de duas semanas do parto, retomavam algumas atividades domésticas, sendo responsáveis por tarefas que não exigissem levantar peso, nem se agachar e/ou levantar-se. As atividades mais pesadas quase sempre são direcionadas para os familiares envolvidos no cuidado da puérpera, como encontrado tanto nos dados deste estudo, como na pesquisa de Reaven et al. (2007).

Sob o ponto de vista tanto cultural quanto biomédico, a revisão da literatura demonstra que as puérperas deveriam priorizar atividades leves, deixando de realizar esforços mais intensos, como arrastar móveis, limpar a casa com rodo e vassoura, realizar agachamentos, descer e subir degraus ou escadas e carregar pesos (Costa, 
2001; Nakano et al., 2003; Chalmico, 2004; Stefanello, 2005; Farias, 2008; Stefanello, Nakano, Gomes, 2008).

Neste estudo, verificamos também que uma atividade evitada pelas puérperas durante 30 a 40 dias foi encher a banheira e/ou jogar a água resultante do banho do bebê. Para estas mães, tal atividade demandaria força, o que prejudicaria a cicatrização, devido ao esforço demandado. No estudo de Chamilco (2004), as puérperas não poderiam carregar no colo e nem maternar os filhos mais velhos, que, por serem maiores, poderiam prejudicar sua recuperação pós-natal. A exceção estava no recém-nascido.

Sendo assim, como os demais cuidados do pós-parto, repouso e evitar esforço físico acentuado se constituem em mecanismos de ajuda para facilitar a cicatrização e a recuperação do corpo materno às condições pré-gravídicas, prevenindo também perdas sanguíneas desnecessárias (Silva, Róldan, 2009; Monteiro, 2011).

A relação entre atividade física e pós-parto foi encontrada no trabalho de Kalinowski (2011), no qual as puérperas recebiam orientação dos profissionais de saúde, em especial do ginecologista, sobre não realizar atividade física durante o pósparto, principalmente nos casos das mulheres que foram submetidas à cesariana. $\mathrm{O}$ DSC que abordou esse tema mostrou que as puérperas relataram depoimentos semelhantes aos encontrados pela pesquisadora citada acima. Salientaram, também, que não poderiam praticar atividades físicas que envolvessem o abdômen durante no mínimo 40 dias após o parto, fatos observados também com puérperas entrevistadas por Raven et al. (2007).

A literatura nos mostra que a prática de atividade física por mulheres submetidas a procedimentos cirúrgicos deve retornar ao normal aproximadamente após 6 semanas de pós-parto.

A falta de exercício de leve intensidade no pós-parto poderia gerar, algumas complicações como trombose venosa profunda, pneumonia, embolia pulmonar, constipação e hemorroidas. Para evitar tais intercorrências, os profissionais devem encorajar as mães, ao retornar para o lar, à prática de atividades leves, mas contínuas, como caminhadas no interior da residência, associadas aos medicamentos para alívio da dor na incisão cirúrgica. Assim, despreocupadas, as puérperas poderiam praticar 
exercícios de leve intensidade, colaborando para sua saúde (Oliveira, 2006); Raven et al., 2007; Evenson, Aytur, Borodulin, 2009; Liu et al., 2009).

Tais práticas de exercício de leve intensidade devem ser incentivadas com o intuito de melhorar a recuperação materna e evitar danos à saúde causados pela estase venosa. $\mathrm{O}$ fato de a mulher levantar-se do leito, deambular e encurtar o período de repouso prolongado ajudaria no restabelecimento da saúde materna; no entanto, como podemos identificar no estudo de Raven et al. (2007), realizado com puérperas de uma província chinesa, apenas 1 dentre 6 mulheres da área rural e 2 dentre 6 mulheres do perímetro urbano realizaram alguma outra atividade, além de caminhar ao redor da casa para promover a circulação sanguínea.

Para as puérperas deste estudo, o repouso prolongado, ainda que por semanas, era incentivado pela sociedade e cultura locais, os quais ditavam que o simples fato de se levantar da cama representaria riscos pelo fato de ser considerado um esforço físico. Ideias semelhantes foram compartilhadas nos estudos de Nakano et al. (2003), Vásquez et al. (2004) e Raven et al.(2007).

Cabe-nos salientar que as crenças em torno dos exercícios físicos no puerpério podem desmotivar a puérpera a iniciar ou retomar tais práticas para sua saúde física e mental. Como visto neste estudo, as puérperas acreditavam que seus órgãos estavam “desnorteados”, ou seja, fora da posição anatômica do corpo e, por isso, o exercício durante o pós-parto poderia gerar danos à saúde. Entretanto, tal receio poderia estar evidenciado apenas no intervalo entre as 4 e 6 semanas de pósparto, no qual ainda se verificavam modificações gravídicas de grande intensidade, mas que não seria proibitiva a prática de atividades leves. Segundo Everson et al. (2009), a falta de informação correta, envolvendo esferas biomédicas e socioculturais, gera incertezas na mulher-mãe e a sua não adesão a tais atividades.

Outras justificativas para que as puérperas não realizassem exercícios físicos no período de 3 a 12 meses após o parto estiveram pautadas no cuidado com o recém-nascido e no cansaço materno ainda que reconhecessem os benefícios para a saúde física e emocional, como a melhora da autoestima (Evenson, Aytur, Borodulin, 2009).

O descanso no leito, além da conotação de evitar esforços maternos, tem ligação com o repouso; por isso, como visto nos dados apresentados nos DSC, 
algumas puérperas alegavam permanecer no leito para descanso, uma vez que, nos intervalos de sono do recém-nascido, deveriam dormir para se restabelecer do cansaço da maternidade. Além disso, a maior parte desses cuidados era perpassada pela rede familiar, em especial pelas mães e avós das puérperas. Eram as mulheres mais velhas e com mais experiência que repassavam tais cuidados, que podem ser vistos também nos estudos de Raven et al. (2007) e Lundberg e Thu (2011), nos quais os cuidados culturais eram transmitidos pelas mulheres mais velhas da comunidade.

No estudo etnográfico de Rice (2000), realizado em Melbourne, Austrália, com puérperas da cultura Hmong, que migraram do leste asiático, verificamos que, para o descanso materno, as atividades domésticas eram realizadas pelo companheiro, quando os demais familiares não pudessem auxiliar.

Outro dado que merece atenção relaciona-se ao fato de tossir ou espirrar, que, para as puérperas deste estudo, significavam forçar o abdômen, assim como andar de moto ou bicicleta. Sendo assim, tais atividades eram consideradas esforços que deveriam ser evitados no primeiro mês ou nos 40 dias após o parto, para que não houvesse intercorrências frente à cicatrização e para que a finalização do puerpério ocorresse sem uma provável recaída. No estudo de Waugh (2011), com puérperas que imigraram do México para o Colorado, Estados Unidos, práticas semelhantes de cuidado e repouso foram identificadas no intuito do restabelecimento materno.

Como parte das práticas de cuidado no puerpério, os DSC reforçaram achados de outras pesquisas, que indicaram que um dos cuidados no puerpério relaciona-se à ausência da lavagem da cabeça nos primeiros 40 dias de pós-parto (Costa, 2001; Castro et al., 2006; Luz, Berni, Selli, 2007; Piperata, 2008; Stefanello, 2005; Stefanello, Nakano, Gomes, 2008; Boer, Lamxay, 2009; Silva, Roldán, 2009; Kalinowski, 2011).

Neste estudo, verificamos que as puérperas nem sempre mantiveram restritamente os 40 dias sem lavar a cabeça, não obstante houvesse o cuidado de não lavar, entre os primeiros dias do puerpério, com variação entre 10, 15 até o máximo de 20 dias sem lavar os cabelos. Houve relatos de mulheres que só retomaram a lavagem dos cabelos após a queda ou retirada dos pontos, enquanto outras, somente 
após cessar a descida dos lóquios, conhecido por elas como a menstruação após o parto.

A descida dos lóquios indica que o sangue retido durante os nove meses de gestação está saindo e limpando o organismo. Caso fosse lavada a cabeça, ocorreria a inversão do fluxo desse sangue, pois a perda sanguínea cessaria imediatamente e o sangue retido no organismo poderia afetar a cabeça, gerando dores fortes e podendo levar à loucura materna (Costa, 2001; Luz, Berni, Selli, 2007; Stefanello, 2005; Stefanello, Nakano, Gomes, 2008; Silva, Roldán, 2009; Kalinowski, 2011).

Puérperas investigadas em pesquisa realizada em uma província chinesa tenderam a não lavar a cabeça e não tomar banho devido à influência familiar: lavar os cabelos geraria dor de cabeça (Raven et al., 2007). Situação também presente junto às puérperas deste estudo, manifestada pelo medo diante da possibilidade de lavagem dos cabelos.

Essas modificações na questão temporal da exposição materna, pela lavagem da cabeça, sofrem modificações de acordo com as transformações sociais e culturais, com o acesso à informação e com a compreensão e crença materna frente a esses hábitos de higiene. Essa condição pode ser confirmada por estudo realizado com população de uma província chinesa, no qual as mulheres residentes na área rural não lavaram a cabeça durante o primeiro mês de pós-parto, enquanto que metade das mulheres entrevistadas que residiam na área urbana realizaram a higiene dos cabelos. Esses dados mostram que a mudança do distrito rural para o urbano pode interferir nas práticas do cuidado, embora, tanto os profissionais de saúde quanto os adeptos da medicina tradicional chinesa desaprovassem o fato de não higienizar o corpo (Raven et al., 2007).

A higiene do corpo por meio de banhos especiais com algumas ervas não deve ser realizada nas duas primeiras semanas de pós-parto por puérperas de comunidades nativas Awajun e Wampis, localizadas no Peru dado semelhante ao verificado com as mulheres deste estudo, em relação à lavagem do cabelo. Contrariar esta prática colocaria a mulher sob maior risco à saúde e demandaria maiores cuidados e privações (Medina, Mayca, 2006).

Também foi observado nos DSC, a relação entre friagem, lavagem da cabeça e recaída no pós-parto, assim como encontrado na cultura colombiana, realçada em 
estudo no qual a cabeça, assim como os poros da pele, a vagina, os olhos e os ouvidos são portas de entrada para a friagem, responsável por resfriar o sangue durante o puerpério. A crença popular mostra que nem a biomedicina ocidental conseguiria reverter os efeitos danosos à saúde da mulher afetada. De maneira simbólica, a lavagem da cabeça seria evitada, pois a água, mesmo quente, é vista como um fator de resfriamento do organismo e, uma vez jogada sobre o couro cabeludo materno, poderia penetrar, resfriando o organismo e gerando a recaída da mulher (Vásquez et al., 2004).

O cuidado e a preocupação com a higiene dos cabelos são demonstrados pelos DSC nos quais lavar a cabeça antes do término do puerpério exige janelas fechadas, para prevenção de correntes de ar, além do auxílio de um secador, com o intuito de reduzir o tempo de exposição ao frio. Procedimentos desse tipo foram encontrados em estudo realizado com a população vietnamita, no qual as puérperas lavavam os cabelos em intervalo de tempo entre 15 a 30 dias de pós-parto, empregando água quente e secagem com secador. Assim como as mulheres deste estudo, as vietnamitas tinham o receio da "síndrome do vento", na qual as correntes de ar causariam cefaleia e dor reumática, podendo, também, gerar sensações dolorosas ao envelhecer, devido à recaída do pós-parto (Lundberg, Thu, 2011).

Os DSC mostraram ainda que as mães não lavavam os cabelos por seguirem crenças culturais, nas quais a friagem, além de causar danos à sua saúde, poderia gerar cólicas intensas no recém-nascido. Um dos poucos estudos com abordagem semelhante relaciona a falta de higiene materna a problemas com o recém-nascido. $\mathrm{O}$ estudo realizado na província chinesa de Fujin encontrou que as mulheres tinham o receio de gerar uma doença infecciosa no bebê, por não se banharem, nem lavar a cabeça. Por estar amamentando e permanecer com o filho a maior parte do tempo, elas tenderam a modificar os cuidados transmitidos pelos familiares, ainda que mantivessem o padrão cultural familiar com algumas restrições durante os 40 dias de pós-parto (Raven et al., 2007).

Os dados mostraram que o cuidado da puérpera com a higiene da sutura perineal ou da incisão cirúrgica, na maioria dos casos, foi realizado com água corrente e sabão durante o banho. Estudo sobre os diagnósticos de enfermagem e as repercussões do pós-parto imediato e mediato, realizado em um hospital de Goiânia 
(GO), mostrou o risco para infecção e integridade tissular prejudicada nos casos das puérperas submetidas a procedimentos cirúrgicos e traumáticos, que abalavam os tecidos corporais (Vieira et al., 2010). Os dados da presente pesquisa atestaram a preocupação com a cicatrização da ferida operatória.

Os produtos de higiene utilizados pelas puérperas para assepsia perineal ou da cicatriz cirúrgica mostraram-se diversificados: sabonete, sabão de coco e sabonete íntimo. Segundo as recomendações do Ministério da Saúde, a higiene no puerpério deve ser incentivada com reforço para as áreas nas quais houver incisão cirúrgica. Recomenda também que a região deva ser exposta, sem curativo oclusivo e que não precisa ser lavada com produtos especiais ou antissépticos, basta higienizar com frequência e observar a aparência da cicatrização (Brasil, 2001).

Em outras culturas, podemos verificar a utilização de banhos especiais com ervas que favorecem a cicatrização da ferida cirúrgica (Boer, Lamxay, 2009; Silva, Roldán, 2009). No caso das mulheres de região rural de uma província chinesa, estudo já citado demonstrou que elas se banham com água fervida com vinho e uma erva com propriedade desinfetante para prevenção de possíveis infecções, em particular, diante de lacerações e incisões cirúrgicas. Paralelamente, no mesmo estudo, vemos que as mães das vietnamitas entrevistadas por Lundberg e Thu (2011) recomendavam para as filhas a limpeza da incisão cirúrgica com água fervida e sal, durante 3 dias após o parto, para prevenção de infecções.

Outro cuidado verificado na limpeza da ferida relaciona-se com a pressão manual ao limpar a incisão, além da pressão gerada pela água do chuveiro com o intuito de limpar, porém sem gerar risco para rompimento da sutura. A literatura mostra que os cuidados com a ferida operatória têm diferentes características variando de acordo com a influência biomédica, cultural, social e familiar em consonância com a crença materna sobre o cuidado (Costa, 2001; Nakano et al., 2003; Stefanello, 2005; Bergamaschi, Praça, 2008; Stefanello, Nakano, Gomes, 2008).

Ainda sobre os cuidados no puerpério, os DSC mostraram também o enfoque dado pelas puérperas a esse período, quando evitavam tomar friagem tanto durante o dia como à noite, calçando meias e pantufas, vestindo blusas de frio e cobrindo-se com cobertor. Para estas mulheres, que permaneciam reclusas no domicílio 
justificando tais cuidados para evitar contato com o ar e com consequências para o recém-nascido, o local mais importante de entrada do frio no organismo feminino seriam os pés, cuja proteção foi encontrada, também, em estudos de Costa (2001), Vásquez et al. (2004), Stefanello (2005), Stefanello, Nakano e Gomes (2008), Lundberg e Thu (2011) e Waugh (2011), que evidenciaram o risco da friagem advinda pelos pés.

Um dos mecanismos utilizados pelas puérperas para se privarem do frio foi permanecer em casa sem se expor ao vento, assim não correriam risco de adoecer ou ter recaída. Tal prática também associou-se ao descanso puerperal; fatos semelhantes foram investigados e evidenciados nos estudos de Sich (1981), Rice (2000), Costa (2001), Nakano et al. (2003), Chamilco (2004), Vásquez et al. (2004), Stefanello (2005), Fleischer (2007), Raven et al. (2007), Stefanello, Nakano e Gomes (2008), Kalinowski (2011), Lundberg e Thu (2011) e Waugh (2011).

Durante o período pós-parto, as puérperas tenderam a permanecer no interior da casa, utilizando roupas que promovessem o aquecimento de seu corpo, com preferência por roupas quentes mesmo durante o verão, pois acreditavam que, além da friagem, o vento também interfere no processo. Dados semelhantes foram encontrados nos estudos de Sich (1981), Rice (2000), Nakano et al. (2003), Chamilco (2004), Vásquez et al. (2004), Lundberg e Thu (2011) e Waugh (2011), demonstrando relações de cuidados similares mesmo em diferentes culturas.

Em outras regiões, as mulheres evitam a friagem com o uso de gorro para a proteção dos olhos, e bolas de algodão para proteger os ouvidos, cuidados culturais não encontrados entre as entrevistadas deste estudo (Vásquez et al., 2004; Lundberg, Thu, 2011; Waugh, 2011).

Os banhos com água fervente e com infusão de ervas específicas ajudariam na manutenção do aquecimento do corpo materno, como encontrado nos estudos de Chamilco (2004), Vásquez et al. (2004), Iliyasu et al. (2006), Raven et al. (2007) e Waugh (2011). No entanto, entre as puérperas deste estudo, não houve a utilização de banho com ervas para o fim de aquecimento e manutenção da temperatura corpórea, fato que possivelmente esteja atrelado à formação sociocultural das puérperas rioclarenses. 
No estudo de Lang e Elkin (1997), realizado com parteiras tradicionais de uma vila pertencente à Cidade de Guatemala (Guatemala), tais profissionais incentivaram as puérperas que moravam em ambientes frios a utilizarem as saunas por um curto período de tempo, pretendendo manter o corpo materno aquecido. Este dado demonstra que mesmo com a diversidade cultural global, o puerpério é um período que, mundialmente, exige a manutenção da temperatura corpórea da puérpera para não adoecer.

Ainda sobre o mesmo tema, outro meio de aquecimento encontrado na literatura refere-se à colocação de pedras ou brasas aquecidas sobre o chão abaixo da cama da mulher, de modo a aquecer o ambiente no qual a puérpera permanece por mais tempo. Trata-se de procedimento conhecido tanto pelas vietnamitas como pelas parteiras da vila localizada na Cidade de Guatemala, que o intitulam de "Deitado no fogo". Seu intuito é de aquecer o organismo, agir sobre o abdômen da puérpera, contraindo o útero para que a perda de sangue no pós-parto seja menor (Rice, 2000; Lundberg, Thu, 2011).

Outra forma de proteção é o desencorajamento das puérperas para lidar com água fria. A explicação reside no estado do corpo que está "aberto" e as mãos seriam "portas de entrada" para a friagem, pois os poros da pele estariam abertos, o que facilitaria danos como febre, infecção, edema e diminuição da produção láctea (Lang, Elkin, 1997; Vásquez et al., 2004).

Além desses sintomas, na cultura vietnamita, a puérpera exposta ao frio sujeita-se a desenvolver anorexia e processo gripal (Lundberg, Thu, 2011). Segundo estudo de Sich (1981), realizado com 30 famílias residentes na área rural de um distrito da Província Kyunggi, localizado na Coreia, caso a puérpera não seguisse os cuidados do puerpério, poderia sentir dores estomacais e reumáticas. Para as mexicanas, que devido à imigração residiam no estado do Colorado (EUA), o simples fato de sair de casa poderia interromper a descida do leite (Waugh, 2011).

Segundo os estudos dirigidos por Sich (1981), Lundberg e Thu (2011) e Waugh (2011), o fato de não se expor ao vento e à friagem fariam com que a mulher se tornasse menos susceptível a doenças neste período. 
Ainda sobre o estudo de Waugh (2011), realizado com as mexicanas imigrantes, a friagem absorvida pelos pés geraria tanto reumatismo como dores ósseas, dores nas articulações, varizes e até mesmo flebite.

O cuidado com a friagem é perpassado pela rede sociocultural familiar; entretanto, pelos DSC, verificamos que as puérperas apenas repassavam o que era apreendido dos cuidadores, sem ter conhecimento sobre o assunto, ou seja, os motivos para manter tais práticas não eram explicados, devendo apenas ser seguidos. Conforme o exposto, outros autores encontraram dados similares em seus estudos com puérperas, que identificaram a permanência de um cuidado cultural no pósparto, porém sem esclarecimentos sobre o motivo pelo qual deveriam ser empregados (Sich, 1981; Helman, 1994; Helman, 2009).

A prática da manutenção do calor corporal no puerpério é realizada como meio da manutenção da saúde materna, mas também do recém-nascido, que deveria ser mantido aquecido para que não ficasse doente ou tivesse cólica (Medina, Mayca, 2006; Waugh, 2011). Dados semelhantes foram relatados pelas mulheres participantes desta pesquisa.

Sendo assim, e de acordo com os estudos relatados nos parágrafos anteriores, a friagem gera grande preocupação, tanto nas puérperas como em suas redes de contato, o que culturalmente incentiva práticas para evitá-la, prezando pela saúde puerperal. Destacamos tal fato, pois vemos semelhanças entre os cuidados culturais de diferentes sociedades ao relacionarmos com os dados encontrados neste estudo, o que demonstram os cuidados culturais sendo transferidos pelos familiares e redes de contato de forma constante.

Outro ponto que surgiu nos DSC refere-se ao tempo de cuidado com a beleza da puérpera, fato que é "roubado" pela maternidade. Nessa situação, a mulher-mãe tende a priorizar os cuidados com o recém-nascido, o que promove adaptações, levando-a a abdicar do cuidado de beleza em prol dos riscos que a criança poderia correr, diante do tingimento dos cabelos ou de escova definitiva e do uso de cremes ou perfumes na região do pescoço e colo.

A maternidade requer mudanças na rotina materna e uma das mais acentuadas relaciona-se aos cuidados com a aparência e a beleza. As puérperas, principalmente no período do pós-parto, abdicam dos cuidados com o lado feminino em prol dos 
cuidados com o bebê e a manutenção do bem-estar da família (Zagonel et al., 2003; Penna, Carinhanha, Rodrigues, 2006; Bergamaschi, Praça, 2008; Stefanello, Nakano, Gomes, 2008; Silva et al., 2009; Kalinowski, 2011).

Os resultados mostraram que as puérperas, mesmo com os novos compromissos da maternidade, gostariam de cuidar da beleza; entretanto, a restrição a alguns procedimentos diante da amamentação gerava angústia frente à vontade de realizar práticas de cuidado com a beleza e não poder adotá-las. Fato também observado por Silva et al. (2009) e Kalinowski (2011), que demonstraram, em seus estudos realizados no período puerperal, as adaptações vivenciadas pela nova mãe a fim de não prejudicar o recém-nascido; ou seja, muitas delas deixaram de realizar procedimentos estéticos devido ao tempo demandado pelo recém-nascido, como também pelo receio de os produtos químicos afetá-los através do aleitamento.

Culturalmente, uma das maiores preocupações da mulher com a beleza relaciona-se com os cuidados dos cabelos. A rede familiar e os profissionais de saúde não recomendaram o uso da tintura de cabelos por conta da química envolvida, assim como a escova definitiva, devido ao formol empregado. Vale esclarecer que na composição da tintura de cabelo há associação de amônia com chumbo, sendo este um metal pesado que, ao penetrar pelo couro cabeludo, pode chegar ao leite materno, além de ficar depositado no organismo da mulher. Ao lactente exposto, os efeitos nocivos se devem à toxicidade do procedimento e podem causar dor abdominal, inapetência, alterações motoras e neurológicas. Quanto à amônia, ainda não há estudos suficientes que comprovem seus malefícios para o recém-nascido, daí a recomendação de ser usada com cautela, como prescrito no manual redigido pelo Ministério da Saúde (Brasil, 2010b).

Quanto à escova definitiva para o alisamento dos cabelos, o formol, utilizado também na composição de fortalecedores de unha, é encontrado em dosagens altamente concentradas, o que oferece risco de intoxicação do bebê, devendo, portanto, ser evitada no período do aleitamento materno (Brasil, 2010b).

Os DSC, relacionados à essa temática, mostraram que familiares maternos mais antigos orientavam a nova mãe para evitar ao máximo realizar tratamentos dentários, cortar o cabelo, cortar as unhas, raspar ou depilar os pêlos do corpo, para evitar inflamação, que, se não cuidada, poderia generalizar, afetar o sangue e gerar 
prejuízos à cicatrização da sutura. Segundo Monteiro et al. (2004), Luz, Berni e Selli (2007) e Diaz et al. (2010) e ainda que tais recomendações possam ser consideradas supersticiosas, o simples fato de ter sido transmitidas de geração em geração faz com que a puérpera procure segui-las para não adoecer, como relatado de maneira similar pelas mulheres deste estudo.

Dados semelhantes foram encontrados na cultura vietnamita, na qual algumas puérperas preferiam não cortar o cabelo, pois acreditavam que teriam queda capilar no pós-parto, embora não justificassem o fato (Lundberg, Thu, 2011). Outra crença popular encontrada e transmitida às puérperas pelos familiares relacionou-se à identificação materna pelo recém-nascido. O bebê, ao reconhecer a mãe, levaria à queda capilar materna como recompensa desse reconhecimento.

Outro DSC que faz parte do universo das práticas de cuidado no puerpério evidenciou o uso da cinta de compressão abdominal. Segundo as mulheres-mães, o uso da cinta abdominal foi encorajado pela rede social e familiar; portanto, trata de prática conduzida pelos aspectos culturais, uma vez que o uso da cinta abdominal quando associada ao profissional como provedor deste cuidado foi de maneira reduzida; no entanto, houve, sim, maior pressão social para o uso desta vestimenta.

Os resultados deste estudo evidenciaram que a cinta ou a calcinha modeladora deveriam ser utilizadas pela puérpera durante o período pós-natal no intuito de colaborar para o retorno do abdômen à condição anterior à gestação. Fatos semelhantes foram encontrados em estudos com puérperas que relataram o uso da cinta modeladora com a justificativa do retorno da silhueta feminina e com objetivo estético de retorno à condição pré-gravídica. Podemos verificar também que as informações sobre os benefícios da cinta provêm do meio social e familiar da puérpera e são demandados pela experiência prévia de outras pessoas de seu convívio com resultados satisfatórios para a musculatura do abdômen, evitando deixá-la distendida e flácida, o que promove a indicação de seu uso (Vásquez et al., 2004; Stefanello, 2005; Kalinowski et al., 2010).

A cinta abdominal e modeladora, neste estudo, foi merecedora de grande atenção da puérpera e de sua família, pois, com a redução da embebição gravídica e a perda de peso materno ao longo do puerpério, trocavam-se os tamanhos das cintas, adaptando-as para que a eficácia de fortalecimento da musculatura fosse mantida. 
Dados semelhantes foram encontrados no estudo de Vásquez et al. (2004), no qual as puérperas eram responsáveis por apertar o abdômen com a ajuda de uma faixa para não se mostrarem gordas e para estreitar a bacia, fato que contribuiu para saída dos coágulos sanguíneos do útero, caso existissem. Neste caso, o uso da faixa colaboraria tanto para saúde como para a estética materna.

O desconforto ao vestir a cinta ainda na maternidade foi tema dos relatos expostos nos DSC. O edema e a sutura, quando presentes, foram os responsáveis por essa situação. Embora exista esse desconforto, a cinta também ofertava certo conforto à mulher, pois retirava a sensação de "vazio" abdominal percebido com a saída do feto. As mulheres da cultura mexicana, de estudo referido anteriormente, utilizavam a faixa de compressão já no pós-parto imediato, porém a mesma, embora ajudasse na recuperação materna, não deveria ser sobreposta à incisão cirúrgica, para prevenir contaminação. Para elas, a faixa abdominal associava-se ao aquecimento do corpo; tanto é que, além do uso de toalhas e pano quentes sobre a musculatura abdominal para a manutenção da temperatura, a faixa seria colocada para aquecê-la e para recepcionar o recém-nascido no colo materno; sendo assim, seria uma vestimenta que ajudaria na manutenção da temperatura materna e do bebê (Waugh, 2011).

Na cultura colombiana, o uso da cinta ou da faixa de compressão abdominal foi visto como um cuidado para a beleza, porém envolvia a involução uterina. Ao apertar os músculos abdominais, o útero retornaria ao seu local fisiológico e ao padrão anterior à gestação, prevenindo, dessa forma, a flacidez do abdômen. Sendo assim, nessa cultura, a regressão uterina estaria ligada à forma da silhueta feminina após o parto. Cabe salientar que, nesta população colombiana, os profissionais da saúde cuidavam das puérperas, ajudando-as a envolver o abdômen com a faixa de compressão (Vásquez et al., 2004).

Uma alternativa adotada pelas puérperas deste estudo relacionou-se ao uso de calcinha com cintura alta, a qual auxiliaria na compressão da região abdominal e daria segurança ao andar. Em estudo desenvolvido na Austrália, as puérperas e seus cuidadores relataram a utilização de algum utensílio para aproximação dos músculos abdominais, pois isso readequaria o abdômen, além de gerar conforto e confiança às mulheres, por manter a tensão abdominal adequada (Rice, 2000). 
Outra crença percebida nos DSC é pertinente à maneira como as mulheres veem o útero após o parto. As puérperas apresentaram a involução uterina com o simbolismo de "mãe do corpo", ou seja, o útero buscaria o bebê "perdido" e com isso provocaria sons semelhantes aos ruídos hidroáereos do intestino, porém com maior sensibilidade, sendo assim, sentido pela mulher.

Dado semelhante foi encontrado em estudo realizado em Ribeirão Preto (SP), com puérperas primíparas com até 40 dias de pós-parto. Estas relataram a existência dos barulhos da "mãe do corpo" após o parto, referindo fazer parte do puerpério. Além disso, salientaram que a mulher deve descansar e repousar para que a "mãe do corpo" retorne ao lugar de origem (Stefanello, 2005).

O descanso e o repouso físico e sexual feito durante o puerpério estavam associados também à apreensão da puérpera frente à crença da exteriorização uterina. Não obstante, o não atendimento dessas recomendações poderia exteriorizar o útero, fazendo com que a mulher voltasse ao serviço de saúde para recolocá-lo na região pélvica.

Tal condição também foi verificada por Waugh (2011), ao estudar o puerpério das mexicanas que residiam no Colorado (EUA); neste estudo, se verificou que a quebra do resguardo sexual colaboraria para a ocorrência de hemorragia no pós-parto e prolapso uterino.

As puérperas associavam os ruídos ouvidos e percebidos por elas no abdômen como relacionados ao movimento do sangue, o que se moveria por toda sua vida caso a "mãe do corpo" não retomasse à sua posição pré-gravídica. A justificativa reside na recaída materna, que estaria associada à teoria humoral, que geraria doenças devido fatores de exposição quente e frio. A teoria humoral e os malefícios para a saúde materna, como encontrado nos dados deste estudo, anteriormente exposto, também foram identificados pelos pesquisadores Costa (2001), Helman (2003) e Stefanello (2005), demonstrando preocupações semelhantes em puérperas que não faziam parte da mesma cultura, mas que mantinham cuidados similares para preservação da saúde da nova mãe.

Cabe salientar que a "teoria" sobre a "mãe do corpo" é formada em grande proporção no seio familiar, pelas mulheres mais velhas que já passaram e 
vivenciaram esta dinâmica, sendo as divulgadoras dos cuidados que levarão o útero ao retorno às condições pré-gravídicas (Stefanello, 2005).

Como relatado nos parágrafos anteriores, as puérperas e seus familiares utilizavam simbologias para traduzir as sensações experimentadas pelos peristaltismos do útero ("mãe-do-corpo"), as quais foram descritas, neste estudo, como "minhoca" ou até sangue proveniente dos lóquios retidos no abdômen. Em estudo qualitativo, realizado com 12 puérperas no interior do estado de São Paulo, também foram encontrados dados sobre o imaginário popular em torno do útero, como uma maneira de explicar as sensações vividas pela involução uterina (Stefanello, 2005; Stefanello, Nakano, Gomes, 2008).

Um dos DSC apontou que as puérperas referiram à abstinência sexual durante o puerpério como forma de se preservar frente a uma possível recaída e até mesmo como uma forma de cuidado e respeito com a fisiologia materna e a regressão gravídica.

Dados semelhantes foram encontrados em outros estudos de Vásquez et al. (2004), Raven et al. (2007), Stefanello, Nakano e Gomes (2008), Salim, Araújo e Gualda (2010), Kalinowski (2011), Lundberg e Thu (2011) e Waugh (2011), que reforçaram a afirmação de que em diferentes culturas e continentes, a prática da abstinência sexual é difundida para as novas mães por seus familiares e pela rede social de contato.

As mulheres referiram que seguiam o "resguardo" sexual como forma de proteção ao seu organismo, principalmente devido à incisão cirúrgica e à sutura perineal. Estudos identificaram dados semelhantes aos das puérperas rioclarenses. Segundo os autores, além de afetar a cicatrização na incisão cirúrgica, o impacto da atividade sexual sobre o aparelho reprodutor feminino poderia deslocar o útero, gerando situações que iriam desde uma hemorragia até um prolapso uterino (Vásquez et al., 2004; Raven et al., 2007; Salim, Araújo, Gualda, 2010; Lundberg, Thu, 2011; Waugh, 2011).

Outro fator social que levava as puérperas a evitar manter relação sexual durante, aproximadamente, 40 dias após o parto, é que temiam engravidar novamente. Dado semelhante foi encontrado, tanto em um estudo brasileiro como em um estrangeiro; ambos prediziam o receio de uma nova gestação em um período de 
adaptação do organismo da mãe ao novo papel social (Salim, Araújo, Gualda, 2010; Lundberg, Thu, 2011).

Algumas puérperas disseram que não praticaram o ato sexual durante $o$ puerpério devido à falta de informação, principalmente relacionada ao uso de anticoncepcional. A justificativa dos familiares perpassava pela ideia de que o corpo estava áspero e não apto para o ato sexual, que poderia levar à ruptura do preservativo masculino, gerando a gestação. No puerpério, quanto antes forem minimizadas as dúvidas e iniciado o planejamento familiar, mais fácil será a adaptação emocional e psicológica da mulher neste período, colaborando para a interação do binômio mãe e filho, conforme estudo de Matijasevich et al. (2009).

Geralmente, o "resguardo" sexual é passado como um cuidado cultural, transmitido pelos familiares, embora as instituições hospitalares também orientem a abstinência sexual por no mínimo 40 dias após o parto. Nossa vivência mostra, no entanto, que o motivo pelo qual a puérpera deve evitar a relação sexual sequer é exposto. $\mathrm{O}$ mesmo ocorre na cultura vietnamita, na qual as novas mães acreditam que não devem ter relação por 3 a 4 meses de pós-parto pelo risco de engravidar e de prolapso uterino (Lundberg, Thu, 2011). Na cultura da população mexicana imigrante para o Colorado (EUA), respeitar o resguardo sexual estava relacionado a elevados danos familiares, até com o risco de morte iminente para a mulher, o parceiro e o recém-nascido, caso a retomada sexual fosse precoce (Waugh, 2011).

Desses achados, apreendemos que a rede familiar e social da mulher tem papel importante na transferência de crenças e valores relacionados ao tempo de “resguardo" e de retorno à atividade sexual (Salim, Araújo, Gualda, 2010).

Ainda que as informações cheguem à puérpera por meio de seu grupo cultural, vale salientar que a própria mulher tem um conhecimento interiorizado e que sabe reconhecer e respeitar seu próprio corpo. Por conta disso, ela deve ser orientada segundo os aspectos biossocioculturais, pois, dessa forma, a cliente seria respeitada em suas crenças e valores, o que colaboraria para um retorno à vida sexual de maneira individualizada (Salim, Araújo, Gualda, 2010).

Outro achado nesta população, já dito anteriormente de forma sucinta, esteve relacionado à prática e ao estabelecimento do aleitamento materno, principalmente relacionado à influência dos lactogogos. Associado a este tinha o interesse materno 
frente à internet como ferramenta de instrução sobre alguns mitos, crenças e cuidados na amamentação. Sobre este tema, destacaram-se também as intercorrências e as dificuldades relacionadas ao aleitamento materno, assim como os cuidados clínicos e de higiene das mamas.

Os lactogogos relatados pelas puérperas, segundo a influência da cultura, levariam ao aumento de sua produção láctea. Dados semelhantes foram verificados no estudo qualitativo de Marques et al. (2011), realizado em Minas Gerais, com 58 mulheres com filhos de até 2 anos, que citaram alimentos que melhoravam tanto o bem-estar materno, como aumentavam a quantidade e a qualidade do leite materno, dentre eles citamos a canja, a canjica, a sopa, o fubá, o arroz doce, o café com farinha e até mesmo os líquidos. No estudo de Farias (2008), as puérperas salientaram usar chá de alfafa por ser considerado uma substância lactogênica, que aprimoraria a produção do leite. Já no estudo de Argote e Vásquez (2005), a puérpera adolescente residente na região de Cali, Colômbia, deveria ingerir bebidas quentes, entre elas os chás de ervas, pois tais alimentos ajudariam a fornecer maior produção de leite materno.

A manobra de aumentar a produção láctea com tais alimentos, mesmo sem estudos concordantes sobre a eficácia destes, possibilitaria quebrar o paradigma do leite insuficiente ou fraco, citado anteriormente e percebido pela população, uma vez que a quantidade tenderia a aumentar, conforme as sugestões advindas das redes de contato social e cultural, prevenindo a complementação e o desmame precoce (Baião, Deslandes, 2006; Canesqui, 2007; Azeredo et al., 2008; Marques et al., 2011).

Por outro lado, os DSC mostraram o uso de cerveja preta como lactogênico; entretanto, ao perceber a quantidade de álcool, tanto a puérpera como sua rede familiar suspenderam o uso, por considerá-la inadequada e em desuso - após se averiguar em sites da internet. Lembramos que a cerveja preta sempre foi utilizada pelas puérperas para aumentar o fluxo do leite materno, mesmo sendo desencorajada pelos profissionais de saúde, por ser prática transmitida de geração para geração. Tal prática perpassada entre as gerações foi identificada também na região do Pará por Ichisato e Shimo (2002) e Vaucher e Durman (2005).

Outro dado cultural que emergiu dos DSC refere-se aos mitos que permeiam o período da amamentação. Dentre eles, o fato de uma mulher menstruada "roubar" o 
leite materno, situação que só seria revertida se a puérpera e a mulher nessa condição se alimentassem juntas. Dados similares foram encontrados em estudos estrangeiros, nos quais a mulher menstruada interrompe a produção de leite pela puérpera, por isso, toda visitante deveria ser questionada sobre a menstruação ou deixar de visitar o binômio mãe-bebê nesse período (Hizel et al., 2006; Osman, Zein, Wick, 2009).

Foram relatados outros mitos característicos do grupo sob estudo; dentre eles, o fato de o leite materno pingar seria causa de interrupção da produção de leite pela mulher. Para evitar tal situação, o local onde o leite extravasou deveria ser lavado com água corrente. Outro dado relacionou-se ao alimento ingerido pela puérpera que não poderia ter os restos ingeridos por algum animal, pois também faria secar o leite. Segundo diversos autores Vaucher e Durman (2005), Marques et al. (2010) e Rigo e Neves (2011), tais crenças e mitos permeiam a amamentação, uma vez que se trata de um ato biológico; entretanto, apreendido pela puérpera por meio de influência cultural, fato que se apresentou nos dados cedidos pelas puérperas entrevistadas neste estudo.

Os mitos e as crenças variam de acordo com os hábitos e a região de cada sociedade; sendo assim, alguns dos achados discutidos anteriormente não tiveram correspondência na literatura pesquisada. Entretanto, verificamos que o "mau olhado" poderia afetar a amamentação, segundo a percepção das puérperas estudadas. Além disso, em outras culturas, o fato de duas nutrizes entrarem em contato haveria risco de mau olhado tanto para a mãe como para o bebê; por isso, esse encontro deve ser evitado (Geçkil, Sahin, Ege, 2009; Osman, Zein, Wick, 2009). Por conta disso, podemos depreender que as puérperas deste estudo preferiram ficar reservadas em seus lares e selecionar as visitas que iriam receber, pois, no imaginário mítico materno, o nervosismo gerado por assuntos considerados angustiantes poderia prejudicar o aleitamento, fato observado anteriormente.

Outro fator identificado foi o cuidado sociocultural indicado para intercorrências com as mamas: o uso de "simpatias", que auxiliam na manutenção do aleitamento, sendo, uma dessas práticas, passar sobre a mama afetada um pente. Tal procedimento dissolveria o leite retesado. O uso da polenta, também apontado

\footnotetext{
${ }^{5}$ Simpatia: define-se como meio pelo qual se afastam males e se conseguem benefícios à saúde, gerando uma aproximação entre corpo e mente; sendo assim, ao se fazer uma magia, se atua com rezas, passes ou benzimento (Weiszflog, 2012). Em estudo realizado por Moura (2011), o termo simpatia indica fórmulas que envolvem magia empregada pela população; além disso, são preventivas e não necessitam de outra pessoa para ser realizadas e têm a intenção de prevenir, restabelecer e proteger o indivíduo que a busca.
} 
nos DSC, refere-se à sua colocação, ainda quente, sobre a área afetada, o que ajudaria a dilatar os ductos lactíferos e a dissolver o leite retido - sua função seria semelhante à de uma compressa quente, que é uma das técnicas não-farmacológica indicadas por Zorzi e Bonilha (2006) e Souza et al. (2008) para alívio de dor nos casos de ingurgitamento mamário e mastite

Outros cuidados com as mamas foram também apontados como o uso de leite materno, ao final de cada mamada, como maneira de proteger a mama, fato comprovado cientificamente, pois o leite contém propriedades esterilizadores e cicatrizantes (Thomson, Morais, 2008). Estudo qualitativo que averiguou as práticas de cuidados frente às intercorrências na amamentação, realizado com 14 puérperas que passavam por consultas em um centro integral de saúde, localizado em Passo Fundo (RS), identificou o uso de chá com ervas medicinais, leite de vaca, nata de leite e sebo de ovelha como meios para recuperar a integridade da pele mamilar e criar uma película protetora (Zorzi, Bonilha, 2006).

As mulheres participantes do presente estudo demonstraram o acesso às informações na internet. Nesta ferramenta, buscaram adquirir (ou certificar-se de) as práticas de cuidado da nutriz, de modo a obter maior segurança; dado também verificado em Amaral et al. (2012).

Um dos cuidados gerados pelo uso da internet foi o emprego de absorvente de seio, como uma maneira alternativa à fralda para aparar o leite, que era indicada principalmente pelas mães e sogras para prevenir que a roupa ficasse suja de leite materno. Como afirmado por algumas puérperas, havia falta de informação dada pelos profissionais, ainda durante as consultas de pré-natal e grupos gestacionais em relação aos aparatos que colaborassem na higiene materna, o que fez com que a maior parte das mulheres não empregasse as conchas ou os bicos de silicone, pois não tinham esse conhecimento, até mesmo por serem primíparas. Por sua vez, os estudos dirigidos por Martins e Martins (2008) e Ravelli (2008) evidenciaram outra realidade, na qual tanto os profissionais de grupos educativos como as puérperas disseram orientar e fazer, respectivamente, uso das conchas de silicone, que, por conter reservatório, além de proteger os mamilos frente a agressões externas, permitia que o leite materno drenado das mamas nos intervalos da amamentação 
ficasse retido neste coletor, colaborando para higiene e bem-estar da mulher, garantindo-lhe independência.

$* * *$

Dentre as práticas de cuidado à saúde, a atenção ao recém-nascido se faz presente no universo pesquisado, ainda que este não fosse o alvo deste estudo. Como vimos anteriormente, a presença do bebê gerou mudanças na alimentação materna. A influência do recém-nascido sobre a saúde materna e, principalmente, nas mudanças dos hábitos alimentares da mulher-mãe também foi identificada nos levantamentos e/ou manuais de Vásquez et al. (2004), Baião e Deslandes (2006), Castro, Kac e Sicheiri (2006), Ichisato e Shimo (2006), Brasil (2009) e Silva e Roldán (2009).

Uma das modificações maternas em prol do recém-nascido também foi deixar de sair de casa, com o intuito de protegê-lo da exposição à friagem, assim como aos demais fatores ambientais e também aos riscos do "mal de sete dias" e/ou do "malda-lua". A friagem, segundo as mulheres, é responsável por várias intercorrências, como a dor de ouvido e a cólica. Esses dados, principalmente relacionados ao "mal de sete dias", também conhecido como "mal-da-lua", foram encontrados no estudo de Iserhard et al. (2009) realizado com 11 puérperas de uma instituição hospitalar no Rio Grande do Sul, que abordou os aspectos culturais do cuidado materno com o recém-nascido, e na pesquisa de Kalinowski et al. (2010), na qual, a partir de uma revisão bibliográfica, corroborou a afirmação anteriormente citada, voltada às práticas de cuidado materno adotadas para evitar danos ao recém-nascido, dado ao excesso de friagem e o dito "mal-da-lua".

Além dos cuidados com o resfriamento do recém-nascido, as puérperas demonstraram cuidado com a roupa do filho, que não deveria ser deixada ao relento ao longo da noite, pois poderia gerar o conhecido "mal-da-lua". A literatura explica que o "mal-da-lua", antigamente, era difundido como o mal que a lua poderia gerar na criança, ou seja, tirar a saúde do bebê. Com o passar do tempo, no entanto, houve uma readaptação e aparece também como o causador das cólicas no bebê, causandolhe desconforto e, portanto, uma forma de "doença" no recém-nascido. Caso a criança fosse acometida por esse mal, só iria ser curada após o batismo, relacionando saúde à religiosidade (Monteiro et al., 2004; Luz, Berni, Selli, 2007; Martins, 2009). Pelos relatos, podemos verificar que o "mal-da-lua" ainda permanece vivo na cultura 
das puérperas rioclarenses, fazendo-as tomar cuidados especiais com o recémnascido; entretanto, observamos que pouco é explicado sobre o porquê manter esta crença.

Também foi verificado que a permanência no interior da residência, por período aproximado de uma semana de vida, do recém-nascido, junto com seus familiares, mãe e pai, ajudaria no estabelecimento do vínculo entre o trinômio, além de deixar a criança mais calma, como identificado na população coreana investigada em um estudo etnográfico realizado por Sich (1981).

Assim como a puérpera se protege do frio, o mesmo é feito por ela com o bebê, que é envolto em mantas e cobertores, além de ser protegido com calça, meias, luvas e toucas, para que seja poupado dos fatores ambientais, com o intuito maior da prevenção da cólica e, muitas vezes, para imitar o ambiente do aconchego uterino. Essa prática não tem respaldo em estudo publicado na revista Crescer (2002), o qual alerta para a existência da gordura marrom. Essa gordura ao ser metabolizada, como descrito no manual de atenção à saúde do recém-nascido, geraria maior aquecimento do recém-nascido, fatos que desmotivaria, portanto, tais práticas, que poderiam contribuir para um desequilíbrio na temperatura do organismo do neonatal e até mesmo desidratação, dependo do tempo que o recém-nascido seja exposto a esse aquecimento (Brasil, 2011).

Assim como os familiares da puérpera, a benzedeira também faz recomendações a ela. Neste caso, houve o alerta para prevenção da friagem ao recém-nascido, com proteção nos ouvidos com algodão, além de cobri-lo com pano, principalmente a parte da cabeça, como uma maneira de resguardá-lo da entrada do frio. Práticas semelhantes foram encontradas em outras culturas, como entre as mulheres peruanas, que, logo após o nascimento, banhavam seus bebês com água quente e ervas para mantê-los aquecidos e aconchegados; além disso, evitavam colocá-los em contato com as correntes frias por um mês, para que não se resfriassem com o "susto" da brusca mudança de temperatura. A prática do emprego de algodão nos ouvidos e do uso de gorro foi encontrada em um estudo realizado com 16 adolescentes colombianas; porém, esse cuidado era empreendido com a puérpera, não sendo referidas estas práticas com o recém-nascido (Vásquez et al., 2004; Medina, Mayca, 2006; Lundberg, Thu, 2011). 
As práticas de higiene do recém-nascido mostraram crenças relacionadas ao banho com emprego de chá de picão e pétalas de rosas. O primeiro, para diminuição da icterícia neonatal e o segundo para amenizar o aparecimento de milium sebáceo e alergias na pele do recém-nascido.

Dados semelhantes foram encontrados em estudo descritivo e exploratório, realizado no Rio de Janeiro por Silva et al. (2007), que visava investigar o cuidado materno prestado aos filhos na residência, buscando identificar crenças desse período; como resultado, foi evidenciado o uso da infusão do picão no banho para acabar com a icterícia e de pétalas de rosas brancas, mas com o intuito de gerar bênçãos ao recém-nascido.

O uso do amido de milho ou maisena na água do banho do recém-nascido recomendado à puérpera está relacionado aos cuidados culturais transmitidos pelos familiares, muitas vezes substituindo o talco, com o intuito de ajudar a evitar assaduras na pele, por auxiliar a secar a epiderme. Vale salientar, no entanto, que dados semelhantes sobre a influência cultural no cuidado do recém-nascido foram encontrados no estudo de Boscatto (2007), no qual o amido de milho foi visto tanto nas fraldas como na região perineal de recém-nascidos no tratamento de dermatite descamativa; o mesmo estudo relatou que as puérperas seguiam tais cuidados, pois eram advindos das práticas familiares.

Outro cuidado comumente encontrado entre as puérperas e seus bebês, evidenciados nos DSC, relacionou-se ao uso de produtos que poderiam causar danos à criança. Como visto anteriormente, os produtos de higiene materna eram evitados, pelo receio que pudessem gerar alergias ao recém-nascido. Dados contrários foram encontrados em estudo recente que envolveu 150 mães internadas em alojamento conjunto e que enfocou os cuidados com o recém-nascido. Ainda no puerpério mediato, foi verificado que $69,3 \%$ das mães, que participaram do estudo, não tinham informação correta sobre o uso de produtos de higiene específicos para o recémnascido, demonstrando falta de esclarecimento sobre o tema, tanto pelos profissionais de saúde como pelas redes sociais e familiares (Andrade et al., 2012).

Dentre os cuidados de higiene, podemos destacar o cuidado com o coto umbilical, que, mesmo com as orientações dos profissionais de saúde sobre como limpar e manter higienizado até a queda, as influências culturais e os rituais para a 
queda manifestaram-se nesta população. Essas mães assumiram usar produtos antissépticos na limpeza do coto umbilical e empregar simpatias para evitar a hérnia umbilical, que é algo comum de ocorrer nos bebês pelo relaxamento da musculatura, conforme Silva et al. (2007).

Ainda é frequente o uso de faixas abdominais no recém-nascido - e muitas vezes acompanhadas com moedas, gases, fumo e alimentos - que podem transmitir doenças infecciosas graves ao neonato. A influência do conhecimento cultural e o desconhecimento materno sobre os motivos que provocam herniação levam ao uso da "faixinha". Estudo recente realizado em Fortaleza (CE), com 150 puérperas, encontrou que $60 \%$ delas afirmaram a necessidade do uso de faixa ou cobertura abdominal para prevenção do "estufamento" umbilical ou da hérnia umbilical (Andrade et al., 2012).

No estudo realizado por Argote e Vásquez (2005) em Cali, Colômbia, com 8 puérperas atendidas em um hospital universitário, pode-se verificar a presença cultural do uso da faixa abdominal junto ao algodão sobre o coto, desde o primeiro dia do nascimento para prevenção da herniação, que poderia ser causada pelo esforço gerado no abdômen do bebê. Ainda, após a queda o umbigo era pressionado com um botão grande prevenindo qualquer deformação desta região.

Em revisão da literatura realizada por Kalinowski et al. (2010), evidenciou-se que os cuidados culturais, como o uso irrestrito das faixas abdominais, levam, em muitos casos, à sua aquisição por ocasião da formação do enxoval do bebê, ao lado da chupeta e da mamadeira.

Dados similares sobre o uso da faixa abdominal no recém-nascido foram descritos neste estudo - e vale ressaltar que não foi apenas por indicação familiar devido experiências anteriores, mas teve início na orientação de um profissional de saúde com formação superior. Sendo assim, o uso da faixa é reforçado pela cultura familiar, mas também pode sofrer influência do profissional de saúde. Na literatura científica, encontramos que o esforço causado pelo choro do bebê sobre seu abdômen poderia gerar a hérnia umbilical, caso não faça uso da faixa de compressão; porém associado ao seu uso, e para restabelecer o padrão de tranquilidade do bebê, a rede familiar incentiva a ingesta do chá como calmante, prática que poderia desencadear o desmame precoce (Argote, Vásquez, 2005; Iserhard et al., 2009). 
O cuidado com o coto umbilical após sua queda, cujo destino poderia influenciar diretamente nas características da personalidade da criança, é relatado pelas puérperas neste estudo e reafirmado em outros estudos. Dados semelhantes foram encontrados na cultura popular, em elevada frequência, e citados em estudos científicos relacionados ao cuidado infantil. A tradição gerou a crença popular que diz que, se um rato ingerisse o coto umbilical descartado, o indivíduo viraria ladrão; caso fosse enterrado embaixo de uma árvore ou próximo a roseiras, a pessoa cresceria bela e meiga; caso fosse guardado junto com a puérpera, geraria o conhecimento que ambos, mãe e filho, permaneceriam unidos na vida (Crescer, 2002; Argote, Vasquez, 2005; Iserhard et al., 2009).

Outro dado que emergiu dos DSC relacionou-se ao corte das unhas do bebê, que deve ser feito por sua madrinha, assim como o tratamento alternativo com fumo e cânfora para solucionar a unha encravada. Vale destacar que estes procedimentos foram orientados por mulheres com maior experiência que a puérpera, que, ao interiorizá-los, passam a repassá-los às gerações futuras. Para que algumas crenças não sejam apenas repassadas de geração em geração, sem que sejam avaliados seus benefícios e malefícios à saúde materno-infantil, o profissional de saúde deve pautar seus cuidados por meio das esferas biomédicas, sociais e culturais, colaborando para que a puérpera possa escolher de forma informada, e consciente, sua prática de cuidado e de seu bebê (Bergamaschi, Praça, 2008; Iserhard et al., 2009; Kalinowski et al., 2010; Andrade et al., 2012).

O emprego de chás em infusão também foi citado pelas puérperas no cuidado do recém-nascido. Foram referidos os chás de camomila, erva-doce e de alface. A grande maioria dos chás foi utilizada para evitar ou minimizar o desconforto das cólicas, enquanto o chá de alface estava relacionado ao sono do recém-nascido e servia como espécie de calmante. A prática dos chás caseiros é comum e quase ancestral, tanto que algumas famílias cultivam as ervas utilizadas no chá na própria residência. Além disso, o recurso do chá para a cólica do bebê é uma alternativa ao medicamento que, por vezes, associa-se ao chá para aumentar e garantir a suspensão do desconforto causado pelas cólicas (Nakano et al., 2007; Iserhard et al., 2009).

Estudo descritivo-exploratório, realizado no Rio de Janeiro, contou com a participação de 38 mulheres que cuidaram dos filhos no domicílio e encontrou que 
aproximadamente $17,5 \%$ destas mulheres usaram chá de erva-doce para alívio das cólicas do recém-nascido, cuja orientação foi dada pela avó e pelas tias da criança (Silva et al., 2007).

A presença cultural familiar ocorre devido à fragilidade da puérpera, principalmente quando é o primeiro filho, por medo e insegurança nos cuidados do bebê; as novas mães recorrem a mulheres mais experientes, que as ajudam na proteção do cuidado do novo membro familiar. Dessa forma, as crenças, os mitos e as simpatias são apresentados para preservar a saúde do bebê. As protagonistas do cuidado compartilhado com a puérpera foram as avós maternas e paternas, as irmãs e a sogra, demonstrando ser um cuidado intrínseco à rede familiar, segundo as puérperas deste estudo relataram. Outros pesquisadores confirmam a situação; pois Vásquez et al. (2004), Argote e Vásquez (2005), Luz, Berni e Selli (2007), Silva et al. (2007), Bergamaschi e Praça (2008), Iserhard et al. (2009), Silva et al. (2009) e Kalinowski et al. (2010) encontraram dados semelhantes em diversas culturas, evidenciando um cuidado cultural e com raízes femininas.

Dentre as crenças citadas e transmitidas pelas mulheres, está o "mal-dos-setedias", conhecido por este nome na medicina popular e que equivale a duas doenças que o recém-nascido pode apresentar ainda durante os sete primeiros dias de vida: tétano neonatal, também dito como "mal do umbigo", pela falta de higiene e nos aparelhos de proteção no momento do parto, e hemorragia gerada pela deficiência de vitamina K (Crescer, 2002; Vieira, Oliveira, Lefèvre, 2006; Silva, Roldán, 2009).

O "mal-dos-sete-dias" caiu no desuso popular, pois tanto o tétano quanto a hemorragia deixaram de ser frequentes no recém-nascido, devido à vacinação e à higienização e à esterilização dos aparatos para o parto, associados ainda ao clampeamento do cordão umbilical; além disso, o protocolo de injetar vitamina $\mathrm{K}$, ainda durante os cuidados com a recepção do recém-nascido no parto colaborou para evitar o quadro de hemorragia. Ainda assim, o medo e a falta de informação adequada relacionam-se à existência deste mal, que, segundo a crença popular, pode acometer o bebê se a mulher receber visitas durante os 7 primeiros dias de pós-parto ou expor a criança em locais públicos (Costa, 2001, Crescer, 2002; Pelcastre et al., 2005; Castro et al., 2006; Vieira, Oliveira, Lefèvre, 2006; Luz, Berni, Selli, 2007; Silva, Roldán, 2009). 
Ainda discorrendo sobre os aspectos culturais gerados pelas redes social e familiar, podemos encontrar as citadas simpatias. Sabemos que a maior parte das simpatias veio da Idade Média e foi trazida por vários povos, dentre eles os da Espanha, África e Portugal, mas, em um país miscigenado como o Brasil, é difícil delimitar a origem de cada simpatia. Como exemplo de simpatia citada nos DSC está a do algodão ou da linha da roupa do bebê em sua testa quando ele está soluçando. Essa técnica ajudaria o bebê a mudar seu foco de atenção do soluço para a testa, fazendo com que o fato desagradável deixasse de existir (Crescer, 2002).

Outra simpatia relacionada ao bem-estar do recém-nascido e familiar volta-se ao sono do bebê. A grande maioria dos bebês não tem estabelecido o horário de sono e vigília; por conta disso, ainda nos primeiros meses, podem confundir os horários e despertar durante a noite, perturbando o descanso materno e familiar. Para evitar essa situação, o recém-nascido é colocado para dormir aos pés do berço e, muitas vezes, pode ser agasalhado com uma peça de roupa do pai, que deve estar próximo à sua cabeça.

Ambas as simpatias gerariam a sensação da presença materna ou paterna por alguns instantes ao seu lado, o que poderia lhe confortar e fazer com que dormisse mais rápido. A roupa com odor paterno despertaria, pelo olfato do bebê, o reconhecimento da presença do pai, gerando confiança e conforto e levando-o a dormir mais tranquilamente (Crescer, 2002; Tomeleri, Marcon, 2009).

Os dados mostraram ainda a influência da benzedeira e das pessoas que trabalham com rezas nas práticas do cuidado mágico-religioso, que tem como intuito a proteção, a cura e o livramento do "quebranto" ${ }^{6 "}$ do recém-nascido. A busca pelo benzimento como forma de complementação do cuidado à saúde do recém-nascido é uma prática cultural na qual as puérperas acreditavam e buscavam. Os familiares, dentre eles os mais influentes, como mães, sogras e irmãs, ensinavam para a puérpera os benefícios do benzimento, como forma de deixar o recém-nascido mais tranquilo e livre dos maus espíritos.

Vimos que as benzedeiras, em sua maioria, tinham alguma ligação com a puérpera ou com seus familiares e amigos. Sendo assim, puérpera, família e

\footnotetext{
${ }^{6}$ Quebranto: Tem como definição: estado mórbido devido mau-olhado nas pessoas, nas crianças, nos animais e/ou nas plantas; podendo indicar ainda abatimento, cansaço e prostração. Segundo o estudo de Árgote e Vásquez (2005) e Fleischer (2007), o quebranto seria a reação do mau-olhado, intencional ou não sobre o indivíduo; fato semelhante encontrado neste estudo, no qual a rede sociocultural transmite que o quebranto seria um adoecimento causado pelo mau-olhado lançado de uma pessoas sobre a outra.
} 
benzedeira compartilhavam aspectos culturais semelhantes, daí a busca pela recémmãe de práticas mágico-religiosas empregadas pelas benzedeiras, vistas com poderes especiais que, por meio de rezas e orações, protegem seus filhos (Luz, Berni, Selli, 2007; Stefanello, Nakano, Gomes, 2008; Helman, 2009; Iserhard et al., 2009; Tomeleri, Marcon, 2009).

Evidenciamos nos DSC alguns sinais que as puérperas apontaram para predizer que a criança estava com quebranto, tais como choro excessivo, irritabilidade, padrões de sono alterado, ou seja, dormir demais ou não dormir e, em alguns casos, assadura, além de brotoejas na face do recém-nascido. Sinais semelhantes levaram puérperas de outros universos culturais a praticarem o benzimento, como no caso da costela pegada, crença comum encontrada na região sul do Brasil, na qual o bebê chora em demasia devido às cólicas intestinais. Outro estudo, realizado com população de uma província na China, verificou que a prática oriental em substituição ao benzimento para as brotoejas seria a utilização de uma erva conhecida como madressilva, que aliviaria tanto os desconfortos cutâneos, como os sintomas de calor e secreção ocular do bebê. Tais práticas são vistas pelos profissionais da saúde como nocivas à saúde do recém-nascido, embora sem evidências científicas que sustentem essa argumentação, mas embasa-se no poder empírico e racional da medicina biomédica, enquanto que o saber popular se manifesta como algo apreendido e incorporado pela vivência frente às crenças maternas (Argote, Vásquez, 2005; Luz, Berni, Selli, 2007; Raven et al., 2007; Helman, 2009; Iserhard et al., 2009).

Na região de Cali, Colômbia, as puérperas entrevistadas relataram levar os filhos ao curandeiro ou benzedeira sempre que acometidos pelo adoecimento espiritual, no caso o mau-olhado, antes mesmo de ser avaliado pelo médico (Argote, Vásquez, 2005).

A ligação e a confiança entre as mães e as benzedeiras levavam as informantes a "encomendar" o benzimento por telefone, uma maneira prática encontrada nesta população; não obstante, quando necessário, o benzimento ou a reza interpessoal era realizado. Estudo qualitativo, realizado com 15 mulheres de uma comunidade popular de Porto Alegre, demonstrou que o benzimento pode ser localizado apenas na região afetada do corpo ou neste como um todo, quando existe 
comprometimento sistêmico da criança; entretanto, o contato entre benzedeira e bebê se faz necessário (Luz, Berni, Selli, 2007).

As simpatias realizadas tanto para as mães como para os recém-nascidos são empregadas com o intuito de barrar ou tentar reverter o quebranto oriundo de "mauolhado" de terceiros ou do excesso de zelo materno. Tais práticas chegavam até as puérperas por meio de pessoas experientes, como mães e sogras, que circulavam em torno da mulher-mãe, ou ainda pelas benzedeiras. $\mathrm{O}$ bocejo ou o choro em excesso simbolicamente representavam sinais de quebranto ou inveja de alguém e, para eliminá-los, deveriam ser empregadas práticas que seriam realizadas pela mãe, uma vez que esta teria o dom próprio de benzer e abençoar o filho.

As simpatias, assim como os chás de ervas e as práticas de benzimento, são atrelados aos cuidados culturais e são transmitidos de geração em geração, com o propósito de gerar cuidado e proteção. Em algumas situações, o emprego da simpatia busca resolver intercorrências com a puérpera ou o recém-nascido (Silva et al., 2007; Tomereli, Marcon, 2009).

$\mathrm{Na}$ literatura, encontramos estudo realizado com mães no Rio de Janeiro, que apontaram simpatias como o uso de fitas ou de vestuário vermelho para evitar o mauolhado durante o início da vida do recém-nascido. A prática de vestir a criança com a roupa pelo avesso também foi evidenciada em uma pesquisa no Paraná, região sul do Brasil, na qual a ação era feita para regular o padrão de sono e vigília do recémnascido, ao contrário da conotação de tranquilizar o bebê, como mostrado nesta pesquisa (Silva et al., 2007; Tomereli, Marcon, 2009).

Outro tema que emergiu dos DSC relaciona-se à pressão vivenciada pela mulher frente à transição para o papel materno. Ao desvelar a transformação de papéis de mulher para mãe, verificamos uma vulnerabilidade devido às oscilações emocionais, psicológicas e sociais que culminaram com as novas necessidades de cuidado do recém-nascido. Não obstante, encontramos que estas mães percebiam a necessidade de dividir seu tempo com novas demandas do recém-nascido e, dessa forma, sentiam a mudança no modo de interagir com o mundo. Esta condição evidencia que a maternidade requer uma nova posição social da mulher, que começa a ser construída após o parto (Soifer, 1986; Jackson, 2006; Merighi et al., 2006; Bergamaschi, Praça, 2008). 
A necessidade de se adequar ao novo papel social materno gerou nas puérperas a responsabilidade em manter o cuidado do filho e, com este foco, tenderam a esquecer de si próprias. Afirmam esse esquecimento do lado mulher para promover o lado mãe os estudos de Soares e Silva (2003), Zagonel et al. (2003), Bergamaschi e Praça (2008), Cardoso e Pereira (2010) e Vieira et al. (2010), os quais evidenciaram, com diferentes desenhos metodológicos, a passagem requerida pela maternidade, além disso, demonstraram a pressão familiar, que faz a puérpera se desligar de seus próprios cuidados ou minimizá-los frente aos do recém-nascido, gerando situações de ansiedade e medo, por não dominar esta nova realidade. Sendo assim, verificamos que, nesses estudos, a situação apresentada não foi diferente da encontrada nos dados do presente estudo, uma vez que em vários DSC podemos evidenciar a apreensão da mulher em estabelecer a função da maternidade.

Em um estudo qualitativo, realizado com primigestas no puerpério mediato ainda no alojamento conjunto em uma maternidade de Curitiba (PR), foi possível verificar que as novas rotinas são impostas tanto pelo bebê como pelos cuidadores (Alves et al., 2007).

Esse novo período estabelecido pelo puerpério implica em modificações no contexto familiar, o que gera na mulher-mãe alterações no seu dia a dia, também no seu cuidado, que vêm acompanhadas por imposições, limitações e transformações em seu cotidiano, colaborando para a vulnerabilidade da transição (Brasil, 2005).

Por isso, o período pós-parto é visto em algumas culturas como um rito de passagem, por ser um momento de transição na vida da mulher, no qual o "velho" daria lugar ao "novo" - e o novo necessitaria de modificações, que levariam as mães a se tornar mais vulneráveis (Vásquez et al., 2004; Jackson, 2006; Medina, Mayca, 2006; Iserhard et al., 2009).

A restrita informação e a falta de preparação para vivenciar o período puerperal aumentam a vulnerabilidade da mulher. Uma das causas dessa desinformação pode ser originária já nas consultas de pré-natal, conforme estudo realizado por equipe multidisciplinar de uma policlínica no Rio de Janeiro, com a participação de mães em um grupo de puérperas, e que mostrou que, de 25 participantes, apenas 4 foram orientadas durante o pré-natal para participar dessas reuniões no puerpério, que poderiam colaborar no aumento do conhecimento do 
período e amadurecimento psicológico diante das transformações exigidas, gerando na mulher menor ansiedade e maior enfrentamento do receio da incapacidade da maternidade (Cardoso, Pereira, 2010).

O cuidado puerperal pelos profissionais da saúde gera um suporte adaptativo nos comportamentos da puérpera; entretanto, se as lacunas e as sobreposições existentes entre os cuidados dos profissionais e da família persistirem, a tendência é o aumento da vulnerabilidade da mulher-mãe, que terá dificuldades em identificar o cuidado culturalmente congruente (Medina, Mayca, 2006; Matijasevich et al., 2009; Kalinowski et al., 2010; Vieira et al., 2010).

Estudo etnográfico, realizado em 1981 em uma comunidade rural da Coreia demonstrou que uma das formas de cuidado da mulher no puerpério era deixá-la com a família nuclear (o trinômio - recém-nascido, mulher e companheiro) por três dias após o parto, no interior da casa, sem interferência de outras pessoas. Tal situação propiciaria a criação do vínculo com o novo membro e a redefinição dos novos papéis, o que, além do descanso materno, ajudaria a não afetar os aspectos psicológicos pela rede social (Sich, 1981).

Ao tratarmos da "Espiritualidade", emergiram relatos que apontaram a frequência da puérpera à igreja e as práticas de orações individuais, além do batismo na igreja católica e a apresentação do recém-nascido nas evangélicas. Estudo exploratório-descritivo desenvolvido por Iserhard et al. (2009) encontrou que a fé materna estava ligada pela oração a Deus e, assim como neste estudo, a oração seria uma maneira de proteger e até curar as possíveis disfunções do recém-nascido. Dessa maneira, a oração seria uma crença culturalmente estabelecida pela prática religiosa que contribuiria para a saúde do binômio (Iserhard et al., 2009; Tomeleri, Marcon, 2009).

O batismo e a apresentação para os evangélicos, embora tradicionalmente diferentes frente aos procedimentos práticos e religiosos, têm o mesmo cunho protetor, pois ambos gerariam bênçãos sobre a criança recém-nascida, protegendo-a de forças externas e sobrenaturais, além de purificá-la de algum pecado e dar-lhe a salvação eterna, afastando-a de maus espíritos, pragas e quebrantos (Luz, Berni, Selli, 2007). 
Sendo assim, as práticas religiosas são incorporadas pelas crenças, que advêm do complexo familiar e social, mas, principalmente, da confiança materna nesta prática de proteção por meio das orações (Tomeleri, Marcon, 2009).

Outro dado que emergiu dos DSC relacionados às práticas de promoção do cuidado mostra que as puérperas que anteriormente colocaram piercing ou fizeram tatuagem, informaram que isto demandaria uma dieta diferenciada, com algumas restrições e que deveriam ser extensivas ao puerpério.

A internet também foi utilizada para promoção da saúde, uma vez que foi empregada para pesquisar sobre a ingesta mais adequada durante o puerpério, dado as necessidades do recém-nascido; pesquisavam, ainda, sobre estrias gestacionais, tanto durante a gestação como no puerpério, em busca de meios de prevenção, assim como para feitura de medicamentos caseiros para resolver o quadro.

Com a globalização e a ampliação ao acesso às novas tecnologias, depreendemos que a internet é um dos meios mais buscados para as relações de troca, de aprendizado, de comunicação e até mesmo de difusão cultural - o que corresponde aos aspectos encontrados nos DSC apresentados (Helman, 2009).

Dados semelhantes sobre a ação da internet no cuidado do binômio mãe e bebê foram registrados em estudo qualitativo e exploratório realizado com 10 mães residentes na região sul do país, no qual verificamos que as informações sobre cuidado da puérpera e do bebê podem ser obtidas por meio da ferramenta da internet, além de livros e de ensinamentos perpassados pela rede familiar, social e biomédica (Amaral et al., 2012).

Por fim, discutiremos os achados relacionados aos cuidadores e às práticas de cuidado adotadas pelas puérperas deste estudo.

Os dados mostraram que são várias as fontes de informações e orientações sobre os cuidados no pós-parto utilizadas pelas puérperas, dentre elas, citam-se: os livros, a internet e os profissionais de saúde. Entretanto, os familiares, com destaque para os mais experientes e do sexo feminino, acabam gerando os maiores impactos no cuidado da puérpera. Dados que afirmam as situações acima expostas emergiram também nos estudos de Alves et al. (2007), Raven et al. (2007) e Amaral et al. (2012), nos quais os meios de atualização das mulheres em relação à própria saúde $\mathrm{e}$ 
à do filho foram encontrados nos livros e na internet, assim como foram também obtidos de familiares e profissionais da saúde.

Os cuidadores também se preocuparam com o resguardo sexual da puérpera e do companheiro. Embora seja um assunto mais intimista e do casal, foi relatado que o médico, a enfermeira e os familiares apresentaram tabus e restrições sobre a sexualidade no pós-parto. Dados semelhantes foram discutidos no estudo de Salim, Araújo e Gualda (2010), que demonstraram e afirmaram que o resguardo sexual deveria ser algo discutido e analisado pelo casal, sem que sofra interferência de terceiros, pois os tabus socioculturais poderiam prejudicar a decisão do casal, em especial, da puérpera.

Notamos, pelos DSC que contemplavam os profissionais, a falta de informação baseada nos aspectos biopsicossocioculturais ao se referir à saúde do binômio. Nesse aspecto, a literatura traz estudos que discorrem sobre a carência de profissionais de atenção integral, o que prejudica as práticas de cuidados de saúde da puérpera, pois foca apenas nos aspectos biomédicos do cuidado (Costa, 2001; Nakano et al., 2003; Stefanello, 2005; Bergamaschi, Praça, 2008; Farias, 2008; Stefanello, Nakano, Gomes, 2008; Silva et al., 2009; Kalinowski et al., 2010; Kalinowski, 2011; Waugh, 2011).

Nos DSC, verificamos as várias esferas que permeiam os cuidados durante o pós-parto materno, relatados anteriormente. Os relatos apontaram para as informações de caráter biomédico advindas dos profissionais da saúde e demonstraram que os responsáveis pelos cuidados puerperais foram os familiares, como também evidenciados nos estudos de Stefanello (2005), Stefanello, Nakano e Gomes (2008), Kalinowski (2011) e Amaral et al. (2012).

Além de seguir orientações advindas do profissional de saúde e de pessoas de sua rede familiar e sociocultural, os DSC mostraram que as puérperas possuíam conhecimento próprio, construído ao longo da vida, por meio da vivência no grupo cultural. Ao socializar a pessoa, já desde o nascimento, podemos dizer que a cultura estabelece um padrão de cuidado, que deve ser considerado pelo humano. Sendo assim, por meio das experiências apreendidas ao longo do processo histórico e cultural ao qual a pessoa é formada, surgem os valores próprios, além das atitudes, 
que são moldadas em cada novo aprendizado e experiência (Nakamura, Martin, Santos, 2009).

Esse conhecimento próprio sobre o cuidado no pós-parto é adquirido pela observação do cuidado de outras mulheres; por isso, dizemos que é um conhecimento passado e adquirido de geração em geração. Ao dialogarem entre si, as mulheres formatam o cuidado e o conhecimento prévio por meio destas interações (Costa, 2001; Nakano et al., 2003; Vásquez et al., 2004; Stefanello, 2005; Nakamura, Martin, Santos, 2009; Lundberg, Thu, 2011; Amaral et al., 2012).

A condição descrita acima nos mostra que uma das primeiras fontes de informações ativadas no cuidado no puerpério é o conhecimento próprio adquirido pela mulher ao longo do tempo; uma vez que, ao vivenciar o momento atual e relembrar as memórias apreendidas junto às redes de contato, delineia as práticas de cuidado (Nakamura, Martin, Santos, 2009; Amaral et al., 2012).

Devemos considerar ainda os cuidadores culturais, responsáveis tanto por repassar novos conhecimentos e práticas de cuidado no pós-parto como relembrar as puérperas a respeito dos conhecimentos que já possuem sobre cuidados nesta nova fase. Os cuidadores culturais manifestam-se pela experiência adquirida ao longo dos anos com as práticas de cuidado com a família, em especial, nos momentos que envolvem rituais de cuidados específicos; sendo assim, ao compartilhar a experiência e o diálogo enriquecem as vivências e os cuidados. Essas afirmativas que demonstraram que historicamente, culturalmente e tradicionalmente, mulheres cuidam de mulheres foram verificadas em estudos de Sich (1981), Costa et al. (2001), Nakano et al. (2003), Zagonel et al. (2003), Chamilco (2004), Monteiro et al. (2004), Vásquez et al. (2004), Stefanello (2005), Fleischer (2007), Raven et al. (2007), Silva et al. (2007), Bergamaschi e Praça (2008), Stefanello, Nakano e Gomes (2008), Liu et al. (2009), Iserhard et al. (2009), Silva et al. (2009), Junges et al. (2010), Kalinowski (2011), Monteiro (2011), Lundberg e Thu (2011), Rigo e Neves (2011) e Amaral et al. (2012).

$\mathrm{O}$ cuidado da puérpera também pode ser prestado por seu companheiro. $\mathrm{O}$ papel do companheiro esteve ligado à rotina alimentar da mulher, embora, na maior parte das vezes, somente quando não existia outra pessoa auxiliando a puérpera, ele ficava responsável também pelos cuidados com o recém-nascido. A preocupação do 
parceiro com as práticas alimentares da esposa expande o padrão de cuidado masculino frente ao puerpério, por isso, destacamos outros estudos que relatam a presença do companheiro no cuidado com a puérpera (Nakano et al., 2003; Chamilco, 2004; Bergamaschi, Praça, 2008; Silva et al., 2009; Amaral et al., 2012).

Ao menos três setores se relacionam no cuidado do indivíduo: o informal, a medicina popular e a medicina biomédica.

O setor informal refere-se à parte das redes de contato familiar e social, são leigos que abordam os temas de saúde, já que, por meio da própria experiência, orientam sobre o cuidado. Enquanto o setor da medicina popular seria composto por pessoas que adquiriram conhecimento com a prática e são especializadas em rituais de cura e tratamento tradicionais, ou seja, não têm ligação com a comprovação científica destas práticas, mas com o cuidado do outro. E, por fim, o setor da medicina biomédica ou profissional, na qual incluem-se os profissionais com conhecimento científico, cuja titulação lhes permite realizar o cuidado pautado na ciência (Kleinman, 1980).

Acreditamos que o saber científico e os advindos da esfera popular e informal devem buscar promover um discurso único, com a finalidade de informar e gerar conhecimento para benefício do binômio mãe-bebê. Além disso, preza-se pelo cuidado individualizado, pois cada vivência é única e, dessa forma, a puérpera poderia passar pelos rituais do ciclo gravídico-puerperal de forma satisfatória, saudável e idealizada segundo desejo da nova mãe e dos familiares (Cardoso, Pereira, 2010; Borges, Madeira, Azeredo, 2011).

Todavia, quando tais modelos de cuidados não interagem entre si, levam a puérpera a buscar em maior proporção os saberes informal e popular como alternativas de preenchimento da lacuna deixada pelo profissional de saúde que a atende. É comum que a prática profissional, voltada para o biológico, desconsidere os princípios, os valores e as crenças da puérpera, colaborando para que a nova mãe se volte para os cuidados apreendidos no contexto sociocultural (Gualda, 1993; Araújo, 2009; Lundberg, Thu, 2011; Waugh, 2011; Amaral et al., 2012).

Os DSC mostraram os profissionais da área da saúde como geradores de regras e paradigmas para o cuidado no puerpério. 
Vale lembrar que, neste estudo, as puérperas encontraram informações sobre os cuidados no pós-parto em dois pólos de saúde: a maternidade e a UBS. A busca por informações sobre cuidados de saúde foi verificada em um estudo realizado no sul do Brasil, no qual, após tentarem ajudar os filhos com o conhecimento próprio, e não solucionado o problema, as mulheres buscavam ajuda em hospitais ou em postos de saúde (Amaral et al., 2012).

Na cultura chinesa, além dos profissionais da saúde envolvidos nas práticas hospitalares, existe a complementação com os cuidadores da medicina tradicional. Devido à diferença de formação, embora trabalhando com o mesmo foco - cuidados no puerpério - encontraram-se divergências nas práticas difundidas por estes profissionais, embora as orientações fossem semelhantes. Um cenário equivalente foi encontrado nesta pesquisa, na qual verificamos divergências entre as fontes de informação utilizadas pela puérpera (Raven et al., 2007).

Vale salientar que os profissionais listados como provedores dos cuidados das puérperas deste estudo eram médicos e enfermeiras. Talvez, por desconhecer a especialidade ou a formação do profissional, as mulheres os identificaram por "moça" do hospital ou do posto para designar quem lhes prestava o cuidado. Dados similares a esse contexto foram encontrados nos estudos de Marchi e Sztajn (1998), Rezende et al. (2002), Helman (2009) e Silva et al. (2009), os quais demonstraram que a falta de apresentação do profissional de saúde contribuiu para sua generalização por parte da população.

No entanto, a quebra do paradigma do cuidado centrado na prática biomédica vem sendo timidamente desfeita pelos profissionais que se envolvem com os cuidados holísticos, ou seja, que prezam por conhecer o cliente de maneira universal, ao penetrar em seu mundo e avaliá-lo e descrevê-lo de maneira individualizada (Helman, 2009; Amaral et al., 2012).

Vale ressaltar que os profissionais foram menos citados pelas puérperas como geradores de seu cuidado, em relação aos familiares e redes de contato, que estiveram mais relacionados ao cuidado, como também foi encontrado no estudo de Silva et al. (2009).

Autores como Salim, Araújo e Gualda (2010), Kalinowski (2011), Lundberg, Thu (2011) e Waugh (2011), com os quais concordamos, acreditam que a enfermeira, 
o médico e as equipes de saúde devem voltar sua atenção para detecção de receios e anseios, aplicando o saber científico às particularidades da cliente, mas valorizando os aspectos socioculturais da puérpera.

Da mesma forma, somos concordes com os autores quando afirmam que o cuidado deve ser pautado em uma interação cliente e cuidador, a fim de decidirem juntos qual a melhor conduta a ser seguida, priorizando o consenso e o respeito entre profissional e usuário (Purnell, 2000; Helman, 2004; Helman, 2009; Lundberg, Thu, 2011; Waugh, 2011).

Notamos que a atenção profissional no puerpério ainda não está consolidada entre as puérperas, uma vez que a maior parte das nutrizes voltou ao serviço de saúde no primeiro mês após o parto, devido a algum cuidado que deveria proceder com o recém-nascido. Por isso, há necessidade de o gestor de saúde e demais setores sociais buscarem uma melhor qualidade na consulta puerperal e mostrarem a necessidade do retorno, sem que seja vinculado unicamente como resultado da puericultura (Brasil, 2005).

Mesmo buscando a humanização, verificamos que os manuais que ajudam na elaboração de protocolos nos serviços de saúde e apresentam as condutas a ser seguidas, embora atualizados, ainda focam no aspecto biomédico do atendimento, pois deixam de abordar com profundidade o cuidado integral e pautado em uma equipe transdisciplinar. Neste estudo, vimos que as puérperas receberam as orientações de diversos profissionais, em mais de uma instituição de saúde, em momentos diferentes, e até com condutas divergentes, colaborando para indecisão materna sobre qual prática seguir e favorecendo o cuidado na perspectiva social e cultural, que lhe transmite responsabilidade no cuidado como no estudo de Vieira et al. (2010).

Por conta disso, muitos estudos com abordagem antropológica sobre o cuidado mostram que os profissionais carecem de atualização, com práticas de educação continuada e que se dispam das próprias crenças e valores para que o cuidado possa ser realizado de maneira integral e culturalmente competente (Purnell, 2000; Costa, 2001; Nakano et al., 2003; Vásquez et al., 2004; Stefanello, 2005; Bergamaschi, Praça, 2008; Farias, 2008; Stefanello, Nakano, Gomes, 2008; Iserhard 
et al., 2009; Silva et al., 2009; Kalinowski et al., 2010; Kalinowski, 2011; Lundberg, Thu, 2011; Waugh, 2011).

Finalizando esta discussão, nos detemos no DSC que foi construído com base nas divergências apresentadas pelas puérperas no seu cuidado e no do recém-nascido. Apresentamos as práticas de autocuidado que desviaram do padrão dos dados apontados nos 20 DSC que o procederam. Como as puérperas mesmo citaram, são os desvios em relação aos cuidados transmitidos tanto pelos cuidadores de saúde como pelos cuidadores culturais.

Nesse DSC, evidenciamos que alguns cuidados foram taxados como inadequados para a era atual e classificados pelas mulheres como antigos, pois são transmitidos por pessoas idosas, que viveram em outro período histórico. Para compreender a maternidade, a mulher e a família passam por modificações sociais e culturais; entretanto, a decisão de seguir ou não uma prática de saúde fica por conta da puérpera - e essa adaptação dependerá dos papéis de poder encontrados na família. Ainda assim, existem puérperas que, mesmo respeitando o cuidado cultural, transmitido com a finalidade de proteção do binômio mãe e bebê, não conseguem segui-lo, por não se identificarem com os padrões exigidos pelos familiares, em especial, os repassados pela avó e pela mãe (Raven et al., 2007; Waugh, 2011).

O fato de não seguir os padrões exigidos tanto pelos cuidadores culturais, como familiares, nem as orientações dos profissionais envolvidos no modelo biomédico, causou mal-estar às puérperas, pois foram responsabilizadas por possíveis danos à saúde materna e do bebê. Fatos como não "guardar" o pós-parto ou não repousar, se expor à friagem e limpar a casa com rodo e vassoura geravam constrangimento, pois seriam atos taxados como irresponsáveis. Essas mudanças não deixam de ser esperadas, pois as ações de diferentes culturas e transformações históricas poderiam fazer a puérpera perder esse paradigma de cuidado transmitido de geração em geração (Waugh, 2011).

O saber cultural molda e submete os sujeitos a padrões, que mesmo sendo esperados, acabam ferindo o conhecimento interno da puérpera. Esta, por si só, compreende as transformações do corpo após a gestação e o nascimento; entretanto, o processo de incorporação dessa mudança ocorre de maneira mais lenta, uma vez que vai sendo construído segundo a experiência com esse novo papel social. 
Todavia, a cultura, em alguns momentos, priva essa nova mãe de vivenciar esse conhecimento de transformação interna, conotando características históricas e impondo-lhe papéis e cuidados, como uma forma de proteger e transformar a puérpera, não obstante, desvalorizando, algumas vezes, os desejos próprios sobre a forma de se cuidar (Nakamura, Martin, Santos, 2009).

Outro tema abordado foram as crenças e as rezas, que, para algumas mulheres, soavam como mitos e "crendices" do povo antigo, como no caso de algumas simpatias para mau olhado. Os mitos e ritos das populações são relacionados a diversas culturas e emanam destas, colaborando no modo de viver dos indivíduos submetidos a esse padrão cultural e social; no entanto, podem não ser universais, uma vez que alguns irão aderir e outros serão contrários (Kitzinger, 1978; Monteiro et al., 2004; Argote, Vásquez, 2005; Penna, Carinhanha, Rodrigues, 2006).

Dependendo do suporte que a puérpera receba nos serviços de saúde, em especial pelos enfermeiros e pelas equipes transdisciplinares, o manejo do puerpério poderá ter um diferencial. Assim como os dados do levantamento bibliográfico, reforçamos nosso entendimento de que o cuidado deva ser individual, levando em consideração os desejos e os conceitos da puérpera, com a finalidade de amenizar os desconfortos causados pela quebra de paradigmas tradicionais, respeitando a interação e definição do cuidado segundo a parceria entre profissional e puérpera (Zagonel et al., 2003; Vásquez et al., 2004; Alves et al., 2007).

Concordamos com os pesquisadores ao afirmarem que o período pós-parto é influenciado pelo sistema cultural da puérpera, de sua rede de contato e familiares; não obstante, cabe-nos salientar que nem sempre essa influência é seguida pela mulher, pois o processo do cuidado próprio e do bebê vai além da cultura e pauta-se na aprendizagem, ou seja, nos comportamentos adquiridos e na crença em uma prática que ache mais eficaz e coerente (Costa, 2001; Nakano et al., 2003; Stefanello, 2005; Stefanello, Nakano, Gomes, 2008; Kalinowski et al., 2010).

A puérpera, assim como os demais usuários dos serviços de saúde, não deve ser vista como passiva e sim devemos destacar a importância do empoderamento para definição do cuidado segundo os preceitos individuais (Costa, 2001; Soares, Silva, 2003; Melo, 2005; Stefanello, 2005; Helman, 2009; Kalinowski et al., 2010; Waugh (2011). 
Por fim, atualmente, preconiza-se e destaca-se a necessidade da aproximação entre os diferentes saberes, aqui representados, como científico e popular, a fim de estabelecer o cuidado culturalmente competente, no qual o indivíduo será cuidado integralmente, deixando de ser submisso ao poder biomédico, ao preconizar um cuidado individualizado, com embasamento científico, mas seguindo suas crenças e valores culturais (Kleinman, 1980; Purnell, 2000; Canesqui, 2007; Iserhard et al., 2009; Nakamura, Martin, Santos, 2009; Lundberg, Thu, 2011; Waugh, 2011).

Após detalhada discussão dos resultados encontrados, a seguir, apresentamos a análise dos achados à luz do referencial teórico adotado. 


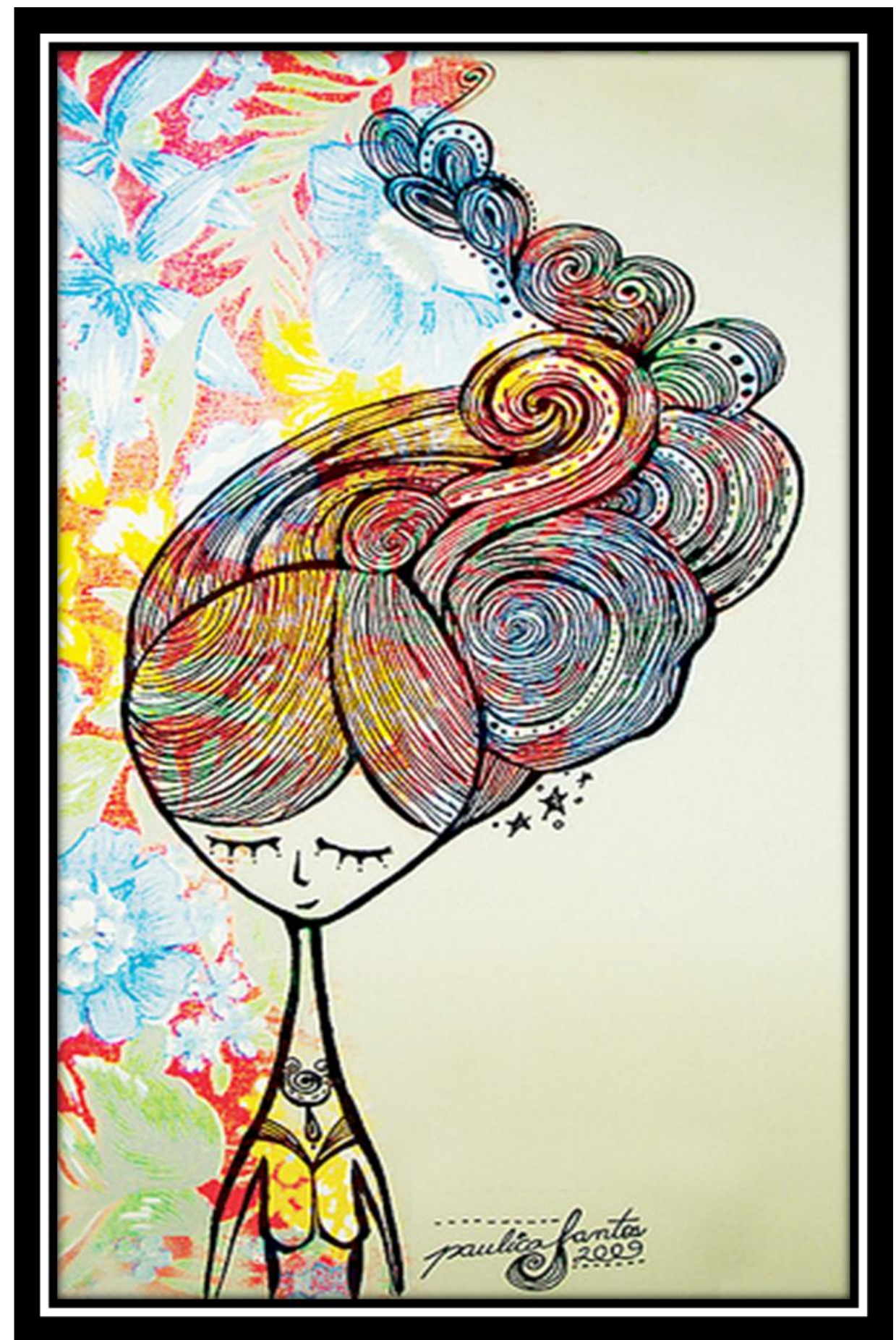

Fonte: http://paulicasantos.wordpress.com/

Análise dos resultados sob a ótica do Modelo de Competência Cultural de Purnell 


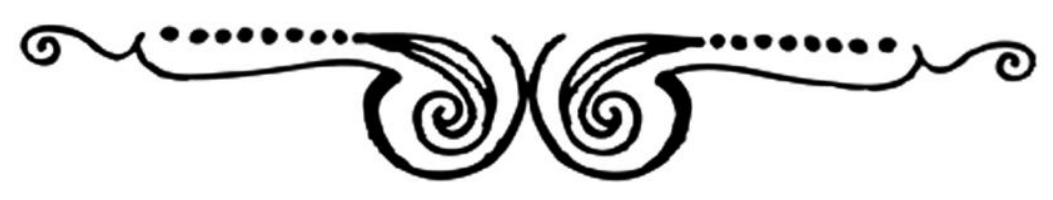

O Modelo de Competência Cultural estabelecido por Purnell e Paulanka, além de estar relacionado com a enfermagem e com demais áreas do cuidado que buscam cuidar do indivíduo de maneira integral permite, tanto ao pesquisador como ao cuidador classificar, de forma individualizada, o usuário dos sistemas de saúde quanto a seus valores, crenças e ações, elevando a satisfação dos mesmos.

Partindo deste princípio, e de acordo com os objetivos e resultados desta pesquisa, verificamos que, dentre os 12 domínios que contemplam o Modelo de Competência Cultural, 9 explicam as práticas de cuidado no puerpério realizadas pelas mulheres atendidas na UBS de escolha e residentes em Rio Claro. Identificamos as crenças e os valores culturais, assim como as orientações que as mulheres recebem para a prática do cuidado no período pós-natal, além de mostrar quem são seus cuidadores no puerpério.

Dessa maneira, no domínio "Herança”, destacamos o nível educacional, pois as puérperas atendidas na UBS, em sua maioria, concluíram o ensino médio; no entanto, não podemos excluir desta população aquelas com ensino médio incompleto e ou as mulheres com ensino superior completo ou incompleto. Vale destacar, que mesmo após o nascimento do bebê, encontramos mulheres que buscam retomar os estudos, uma vez que seria uma garantia de um futuro melhor para o filho. De onde deduzimos que alcançar maior nível de escolaridade seria garantia de melhor status social, com maior possibilidade de obter um emprego de qualidade.

Quando se trata de renda, verificamos que é reduzido o número de mulheres que desconhecem a renda familiar, que não trabalham e que não participam da dinâmica salarial da família. A renda familiar destas mulheres encontra-se na faixa de 3 a 4 salários-mínimos. Ao analisarmos esta situação, podemos evidenciar que a renda familiar varia de acordo com o número de moradores em uma mesma residência; no entanto, não é possível discorrer sobre as atividades empregatícias e sobre as pessoas responsáveis por garantir a renda da família, pois não foi explorado o universo da ocupação da puérpera, assim como de seus familiares responsáveis pela manutenção da renda. 
Ainda neste domínio, verificamos que as mulheres estudadas moram com alguma pessoa e, em sua maioria, residem com o companheiro, enquanto algumas delas salientaram deixar suas casas para morar junto com a família do companheiro, pois, dessa maneira, seria uma forma de dividir responsabilidades e de contribuir para uma forma de ligação entre o casal e o recém-nascido. Destacamos ainda que a maior parte mantém contato com os pais e com os sogros, sendo também membros de suas redes de contato os irmãos, os tios, os primos e, em alguns casos, os enteados.

No domínio "Papéis e organização familiar", encontramos as relações de gênero, frente algumas práticas de cuidado, e a importância dos papéis familiares. Para a maior parte destas mulheres, a constituição familiar corresponde à união com o companheiro. Por isso, a maioria convive e reside com estes, mesmo que compartilhando a casa com familiares. Esta situação mostra que são núcleos caracterizados como famílias mistas, nas quais há relação entre pais, irmãos e companheiro.

As famílias com padrão misto facilitam o contato da mulher com seus ancestrais, como as avós - e em menor número com bisavós - o que colabora na manutenção de rituais de cuidado no pós-parto, pois, por ser mulher, deveria se cuidar, seguindo o papel de gênero transmitido pela ordem familiar.

$\mathrm{O}$ fato de ser mulher, na perspectiva familiar e antropológica, mostra a importância e a responsabilidade da puérpera pelo cuidado. Por meio da história da civilização humana, encontramos que as mulheres são responsabilizadas pela promoção do cuidado, com o intuito de contribuir para a continuidade da vida. Além disso, a mulher seria responsável tanto pelo autocuidado como pelos cuidados dos familiares que, no caso das puérperas, são representados pelo recém-nascido e pelo companheiro. As mulheres desse grupo deixam de realizar algumas atividades, em prol das exigências da maternidade; sendo assim, evidenciamos que, ao menos nos primeiros meses de pós-parto, a puérpera tende a permanecer mais quieta em sua residência em companhia do recém-nascido, e dos demais familiares, como uma escolha para passagem pelo período puerperal.

Vale salientar que as puérperas se percebem como responsáveis pela maternagem, fato pertinente à sua condição de representantes do gênero feminino. 
Ao avaliarmos as formas e a composição das famílias e as atribuições de cuidados próprias do gênero feminino, conseguimos contemplar melhor a realidade da usuária, fato que deriva um cuidado mais individualizado e respeitoso, além de contribuir para que este seja culturalmente congruente.

Vemos a influência do conhecimento intergeracional perpassado entre os familiares, o qual direciona as práticas de cuidado de saúde das puérperas rioclarenses.

Observamos, ao investigar o domínio "Força de Trabalho", que a maioria das puérperas atendidas na UBS de Rio Claro é proveniente da própria região, mas descendem de familiares imigrantes, o que pode ter influenciado na tomada de decisão sobre algumas práticas de cuidados de saúde realizadas durante a fase puerperal. Por conta disso, verificamos alterações alimentares específicas de algumas regiões das quais os descendentes familiares eram provenientes; um fato exposto foi o uso de pirão de galinha caipira e rapadura, típicos lactogogos provenientes das famílias oriundas das regiões norte e nordeste do Brasil.

Sendo assim, conforme a aculturação sofrida no âmbito familiar da puérpera, podemos verificar que os modelos de cuidado são perpassados, mantendo essas raízes do estado ou do país originário, ou acabam sendo adaptados aos costumes da sociedade local e, em alguns casos, podemos encontrar até exclusões de algum aprendizado proveniente de outra região quando considerado por elas.

Ainda seguindo os domínios do Modelo de Competência Cultural de Purnell, avaliamos o domínio "Comportamento de alto risco", no qual os hábitos e os vícios maternos mostram-se reduzidos, embora estejam presentes naquele contexto representados pelo hábito de fumar, ingerir bebida alcoólica, ser usuária de maconha e cocaína. Chama a atenção que estes hábitos, que aumentam a vulnerabilidade da mulher a doenças, parecem ser usados fora do ciclo gravídico-puerperal.

Este achado mostra que as drogas ilícitas permanecem distantes do contexto destas mulheres, embora a preocupação com o concepto/recém-nascido seja fundamental na prevenção de comportamentos de risco. A maternidade e suas novas responsabilidades definem o padrão de comportamento preventivo esperado para a puérpera. 
Devemos considerar que, no que se refere ao uso do álcool, este é ingerido socialmente. A dificuldade em quantificar universalmente os padrões normais e anormais do abuso de álcool prejudica a definição do padrão de alcoolismo, que também depende de padrões sociais e culturais do contexto analisado.

Se o tabaco e o álcool são pouco consumidos, os chás são bebidas muito utilizadas na fase de puerpério, tanto para uso próprio como para o recém-nascido. Chama a atenção o emprego do chá de arruda com pinga para o encerramento do ritual do resguardo. Seu uso embasa-se no significado de que todas as doenças e uma possível "recaída" durante o resguardo seriam eliminadas antes do "fechamento do corpo", daí a necessidade de ingestão deste chá. Acreditamos que sua ingestão, ainda que pontual, poderia causar dependência psicológica e emocional na mulher, pois o fato de ingeri-lo no dia que poderia não ser exatamente o considerado como último do puerpério, não traria o efeito esperado e transmitido culturalmente, o que geraria uma preocupação perene da mulher pela manutenção de sua saúde.

Ainda como parte deste domínio, verificamos que essas puérperas não praticam atividade física durante o puerpério. Esse contexto pode ser explicado pelo fato de que o pós-parto é visto por elas como período de resguardo, o qual deve ser intensificado nas puérperas submetidas à cesárea, devido ao risco de ruptura das suturas.

Outro fator que estimula a ausência de atividade física se deve à ausência de orientação do profissional de saúde, que uma vez agregada à influência das redes familiar e de contato, reforçam o contexto para que sejam evitados exercícios físicos no puerpério. Vale salientar as divergências das orientações fornecidas pelos profissionais entre si, uma vez que, para alguns, seriam necessários 3 meses de ausência de atividades e, para outros, este tempo poderia ser bem menor, o que gera conflito interno na puérpera sobre qual prática se guiar.

Como parte desse domínio, verificamos que as puérperas seguem uma dieta com excesso de calorias, uma vez que uma parte delas consome alimentos mais ricos em carboidratos com o pensamento de beneficiar a produção do leite materno. Vale ressaltar que, no grupo sob estudo, ocorre readequação da alimentação visando a saúde materna e do recém-nascido; sendo assim são evitados no puerpério doces, 
frituras e salgados. Portanto, o ganho calórico se deve ao aumento de carboidrato na alimentação materna, o que eleva os riscos à saúde das mulheres.

A prevenção de acidentes, neste estudo, pode ser compreendida como prevenção de risco à saúde. Estas puérperas demonstram um cuidado excessivo com a saúde, para prevenir o que chamam de recaída. Consideramos que o conhecimento cultural impregnou tais mães, o que as leva ao receio e ao medo de realizar situações que poderiam afetar seu restabelecimento. Além das alterações no padrão alimentar, na atividade física e nas práticas de higiene e vestimentas, verificamos que o ato de espirrar também se manifestou como uma situação de risco para a mulher; então, deveria ser prevenido.

Podemos destacar como manobra protetiva, realizada por algumas mulheres, o uso da cinta modeladora ou da calcinha de cintura alta para prevenção de acidentes com a sutura, além da contribuição para restabelecimento da forma estética anterior ao parto. Tais atitudes, perpassadas, na maior parte, pelos familiares e pelas redes de contato, colaborariam, segundo a ótica da puérpera, para a prevenção de danos e acidentes.

Cabe-nos destacar que não são todas as puérperas que têm atitudes voltadas ao resguardo e, quando isso não ocorre, a pressão social e cultural é intensa, demonstrando que, ao se desviar da regra condizente com os princípios e valores populares, a mulher é estigmatizada.

Ao investigar outros dados puerperais, no ritual do nascimento, encontramos desde crenças e tabus associados à alimentação até a readequação dos alimentos para o restabelecimento e a manutenção da saúde materna. Some-se que os alimentos têm significado simbólico pautado nos aspectos socioculturais, como podemos evidenciar pela análise do domínio "Nutrição", no qual encontramos várias crenças e vários tabus em relação não só ao alimento, mas também às maneiras de se alimentar.

Verificamos, no grupo de puérperas estudado, assim como nas diferentes sociedades e culturas, que o alimento é essencial para a manutenção da vida e, ao mesmo tempo, pode gerar danos, devido à particularidade do momento experienciado pelas pessoas. O que compreendemos é que, conforme a etapa da vida e as condições do bem-estar dos indivíduos envolvidos nesse processo de alimentação, o alimento receberá uma designação. Tanto é que algumas puérperas 
consideram a banana e o morango como fontes riquíssimas de ferro para o combate à anemia do bebê; entretanto, estes alimentos deviam ser evitados restritamente, nos 40 dias de puerpério, pois podem afetar o neonato, por gerar desconforto intestinal por consequência da amamentação. Após esse período, ocorre o incentivo familiar, em consonância com o desejo da mulher para que tais alimentos sejam incluídos na dieta e passem a ser ingeridos.

Também evidenciamos situações em que um alimento tem de ser consumido pela puérpera, no caso a couve, dado seus benefícios pelo alto teor de ferro e, principalmente, pelo fato que, dessa forma, a criança se acostuma com o alimento e, ao crescer, passa a ingerir todos os alimentos que compõem a dieta materna. Este fato nos remete a uma ideia paradoxal, uma vez que muitos alimentos são evitados pela puérpera, privando, de maneira indireta, que o bebê experimente novos sabores, uma vez que, para estas puérperas, o alimento ingerido por elas daria diferente sabor ao leite. Não podemos excluir casos nos quais a família responsável pela puérpera retira a carne vermelha de sua alimentação, justificando que, por ser rica em ferro, poderia gerar um acúmulo prejudicial do mineral no organismo feminino na fase puerperal.

O estudo da literatura nos direciona a crer que os preceitos trazidos ao longo da vida e reforçados pela cultura e sociedade levam a mulher a acreditar que a alimentação no puerpério deve ser especial, dando ênfase principalmente para os alimentos que julgam ser lactogênicos, ou seja, que aumentariam a produção do leite.

Por aumentar a produção láctea materna, os lactogênios são amplamente utilizados por essas puérperas, principalmente devido às redes familiar e de contato disseminarem a manutenção destes alimentos para promover a produção láctea.

Podemos inferir que as crenças e os tabus acerca destes alimentos são elevadas e que, talvez, o fato de não utilizá-los poderia interferir na dinâmica psicológica da puérpera, fazendo com que a produção de leite diminuísse ou até mesmo cessasse, uma vez que o fato de não utilizar esses alimentos na dieta materna poderia simbolizar que o leite estivesse "fraco" ou até "aguado". Para este recorte de mulheres, os alimentos lactogênicos, em sua maioria, são representados pelo aumento da ingesta hídrica, leite, milho de canjica, água na qual a canjica permaneceu imersa ou até mesmo a canjica "temperada", que seria feita com leite e 
adoçada. Em alguns outros casos, não se exclui o uso do pirão de galinha caipira e rapadura, em especial, usados pelas puérperas com familiares das regiões norte e nordeste do Brasil, assim como o uso de cerveja preta. Notamos que a ingestão desta bebida pode ser interrompida por informação encontrada na internet, outra fonte de orientação da puérpera, que reforça cuidados para que evitem a ingestão de bebida alcoólica como proteção ao recém-nascido.

Durante o puerpério, estas mulheres tornam sua alimentação mais saudável, preferindo alguns tipos de legumes, vegetais e carnes leves, e buscam excluir doces, guloseimas, alimentos ácidos, cítricos, gordurosos e reimosos, por acreditarem que estes prejudicam-na diretamente e, indiretamente, ao recém-nascido, por meio do aleitamento materno.

A população estudada e seus familiares vêem o ovo como um fator que pode interferir na cicatrização da ferida operatória e prejudicar seu restabelecimento. Tal crença demonstra que a alimentação é altamente simbólica nesse contexto cultural. Sendo assim, verificamos outros alimentos que vêm simbolizados por crenças e tabus durante o pós-parto, como o caso dos alimentos gordurosos, representados pela carne de porco, carne com excesso de gordura, fritura, hambúrguer, embutidos e salgadinhos, que podem gerar problemas na cicatrização da episiorrafia ou da incisão da cesárea, podendo ainda causar desconforto intestinal, por meio dos gases no recém-nascido e que, por isso, devem ser evitados durante o puerpério.

Os alimentos ácidos e cítricos, tais como algumas frutas - tomate, abacaxi, maracujá, laranja e limão - molhos de tomate e temperos de salada, como vinagre, são retirados da dieta, uma vez que essas mulheres acreditam que prejudicam a cicatrização e acidificam o leite materno, fatos que podem tanto gerar gases no recém-nascido como levar ao desmame, devido à mudança no sabor do leite.

Verificamos também que a puérpera tende a ingerir alimentos que regulem o hábito intestinal do recém-nascido. Se diarreia, a mulher busca comer maçã, a qual representa uma fruta ressecativa; enquanto que a obstipação intestinal requer alimentos laxativos como o mamão.

Esse quadro também é seguido para restabelecer a motilidade intestinal puerperal; sendo assim, para que o intestino volte a funcionar normalmente a puérpera dá preferência ao mamão, à aveia e ao iogurte - com princípio ativo que 
regule o "trânsito" intestinal - de modo a prevenir a constipação, que, se permanente até o "fechamento" do pós-parto, perduraria até a próxima gestação.

Uma crença presente no contexto das mulheres sob estudo relaciona-se ao arroz amanhecido, fato que, em sua visão e de seus familiares, gera aumento da leucorreia materna.

Vale destacar que a segregação dos alimentos considerados prejudiciais se limita a 40 dias de pós-parto, surgindo o questionamento dessas mães nutrizes que não compreendem a liberação desses alimentos após os 40 dias, pois continuam amamentando.

Notamos que as próprias puérperas repassam suas crenças em seu contexto, mesmo não compactuando integralmente com as crenças do seu meio sociocultural. Se têm apresentam dúvidas, procuram esclarecê-las com algum profissional; entretanto, pode haver necessidade de buscar atendimento privado para obter informações satisfatórias, uma vez que consideram que a duração da consulta, ou a permanência junto ao profissional da rede pública, é estritamente restrita. Além disso, a ausência de orientação convergente, ou seja, uniforme, por parte dos profissionais, dos familiares e da sociedade gera maior apreensão nessas puérperas, levando-as a optar por práticas, nem sempre fundamentadas no saber real, mas em uma replicação de valores.

Assim, a maior parte dessas mulheres modifica sua alimentação em função da educação e da orientação perpassadas pelas redes familiares, em primeiro lugar, seguidas pelas informações complementares fornecidas por profissionais de saúde e redes de informação, como a internet e os livros.

Ainda prezando pelos cuidados culturalmente competentes, verificamos o domínio "Práticas na Gravidez, no Parto e no Puerpério", do Modelo de Competência Cultural, que corresponde às vivências diante de crenças e valores no ciclo gravídico-perperal.

Encontramos que as crenças permeiam as fases do ciclo gravídico-puerperal, principalmente as transmitidas pelo meio familiar, entre filhas, mães e avós.

Primeiramente, o período após o nascimento do bebê é conhecido pelas puérperas como um período que merece cuidados especiais; portanto, recebe, em sua maioria, o nome de resguardo, quarentena ou dieta. Para essa população, as 
principais mudanças no cuidado estão ligadas às mudanças nos hábitos alimentar, sexual e de higiene, assim como para repouso, descanso, evitar esforço físico e exposição ao frio, mudanças na vestimenta e no papel social da mulher.

Ao considerarmos outros aspectos, verificamos que, para estas puérperas, a exposição ao frio, representada pelas chuvas, chuviscos, sereno e vento, pode causar danos à saúde materna. Acreditam, segundo suas redes familiares e de contato, que a friagem gera inversão do humor sanguíneo; sendo assim, ao invés de seguir o fluxo de saída pela loquiação, o sangue fica retesado em seu organismo, o que lhes causaria, no presente, cefaleia e, no futuro, dores nas articulações e nos ossos; tais sintomas estariam relacionados à recaída não curada. Portanto, para essas puérperas que se expuseram a fatores ambientais, que colaboram para o resfriamento do organismo, a única alternativa de cura é a ingestão de um chá, na maior parte das vezes preparado pela mãe ou pela sogra, feito com ramos de arruda e pinga, que deve ser ingerido no último dia do puerpério, pois retira todos os tipos de recaída do organismo feminino.

Há, no entanto, mulheres que se expõem às correntes frias, por achar que as opiniões oferecidas pelos poderes popular e leigo são ultrapassadas, destacando que tais informações e orientações são ofertadas por mulheres com conhecimentos desatualizados.

Outro destaque importante diz respeito à algumas puérperas que, por medo da recaída no puerpério, acabam cometendo alguma extravagância de maneira moderada, pois, caso sejam acometidas por alguma intercorrência de saúde, esta não geraria danos tão devastadores, como esperado, se as regras de cuidados fossem totalmente quebradas. Um exemplo deste quadro é o fato de ingerir algo gelado e, em seguida, quente, com intuito de equilibrar e proteger o organismo.

Evitar esforços físicos é outra prerrogativa destas mulheres. Para elas e seus familiares o esforço pode gerar danos na sutura perineal ou na incisão cirúrgica da cesárea e, em casos extremos, o útero pode se exteriorizar, uma vez que a cicatriz poderia se romper, além de provocar hemorragia. Esse cuidado é perpassado por profissionais da maternidade e da UBS; entretanto, como não há consenso do tempo exato que deve ser mantido esse repouso, as mulheres ficam em dúvida sobre este intervalo e interrompem o cuidado segundo sua própria iniciativa. 
Destacamos que, para esta população, o uso da vassoura e do rodo antes dos 40 dias é considerado um desvio do cuidado no puerpério e deve ser evitado. Outra prática considerada de esforço é o ato de lavar, ou simplesmente torcer e pendurar, as roupas do recém-nascido, pois acreditam que os movimentos envolvidos nessa atividade afetam a cicatrização, principalmente na presença da episiorrafia. Daí contarem com uma pessoa que lhes auxilie nesse serviço doméstico, quase sempre a mãe, a sogra, a irmã.

Vale salientar que não é comum, neste grupo de mulheres, se permanecer sem lavar o cabelo durante todo o pós-parto. Podem lavar os cabelos ao menos uma vez, depois de duas a três semanas de pós-parto, dando preferência aos dias quentes para que não haja perigo de choques térmicos. São mulheres que utilizam o secador de cabelos, mas que também empregam a "chapinha" com o intuito de secar o cabelo, se precavendo da friagem.

Essas mulheres optam por efetuar a limpeza da cicatriz operatória e da episiotomia apenas com água e sabão; saber transmitido pelos profissionais de saúde, tanto da maternidade como da UBS; porém as informações de familiares e populares não são descartadas, pois utilizam, também, sabão em pedra e sabonete íntimo, que acreditam ser mais eficientes do que a simples lavagem com sabonete convencional. A pedra hume, que teve seu uso orientado pelos familiares, é citada por esta população como um artifício que colaboraria para a cicatrização mais rápida da episiorrafia, entretanto, seu emprego foi descartado pela puérpera.

Verificamos, nessa população, que os cuidados relacionados aos hábitos de beleza feminina são rebaixados a segundo plano; ou seja, a preocupação com a maternidade e o estabelecimento de vínculo com o recém-nascido usurpa a maior parte do tempo das puérperas. Além disso, outro fator limitante dos cuidados com a beleza é o aleitamento materno, que impede as puérperas de colorir os cabelos e de realizar relaxamento químico, pois acreditam que as substâncias envolvidas em tais procedimentos afetam diretamente o recém-nascido, por meio do aleitamento.

Essas recomendações são perpassadas pelos familiares e pelos profissionais de saúde; entretanto, não há consenso sobre o tempo que a puérpera deve deixar de utilizar tais produtos químicos. De todo modo, não podemos excluir uma parcela de 
mulheres que acaba realizando procedimentos de beleza por considerar o procedimento pontual, consequentemente não prejudicial ao bebê.

O uso contínuo de creme e óleo hidratante nem sempre é interrompido pelas mulheres durante o puerpério, embora acreditem que o perfume poderia gerar processo alérgico no recém-nascido; por isso, aquelas que os utilizam, o fazem com aplicação de produto sem fragrância em regiões nas quais o bebê não tem contato, como braços e pernas.

O cuidado destas puérperas está intrinsecamente relacionado ao cuidado com o recém-nascido; sendo assim, tudo que é prejudicial a ele deve ser evitado em seus primeiros meses de vida, em especial, no período do pós-parto.

As crenças familiares, transmitidas pelas relações intergeracionais, se mostram presentes no contexto destas puérperas pela mudança de vestimentas. As puérperas dão preferências por roupas que geram aquecimento, tais como meias, blusas, casacos e chinelo. Esta opção relaciona-se ao fato de evitar a entrada de frio no organismo, que geraria tanto inversão humoral, quanto o processo de recaída. As mulheres que não seguem estritamente essa recomendação, e que se expõem tanto ao sereno como às correntes de ar frio, são cobradas pelos cuidadores sobre essa atitude de risco e vulnerabilidade.

Outra vestimenta utilizada no momento do pós-parto é a cinta modeladora ou a calcinha de cintura alta, cuja indicação de uso emana da rede de contato social e familiar da puérpera, com o intuito de contribuir para o retorno original da musculatura abdominal, de modo a remodelar o corpo. Os profissionais da saúde da maternidade também indicam seu uso. As puérperas sofrem enorme pressão social para utilizar este aparato do vestiário, mesmo diante do desconforto causado, pela compressão da cicatriz cirúrgica. Além dos aspectos para beneficiar a beleza, a cinta tem a função de proteção da incisão cirúrgica; sendo assim, todo vez que se alarga, outra cinta com maior resistência é providenciada, para que a tensão dos músculos abdominais seja mantida.

Um cuidado advindo de fontes sociais e culturais ligadas às mulheres relaciona-se à posição do útero, chamado de "mãe-do-corpo". As mulheres assemelham a "mãe-do-corpo" a uma minhoca ou a um bicho, devido à sensação provocada pela involução uterina. As sensações oriundas da "mãe-do-corpo" 
assemelham-se às cólicas menstruais e servem para que a mulher descanse física e sexualmente durante o puerpério; por outro lado, a prática sexual antes do término do puerpério afeta a "mãe-do-corpo", fazendo-a exteriorizar-se.

A abstinência sexual é outro fator observado pelas puérperas em estudo. A prática do resguardo sexual é orientada por profissionais de saúde, pois não é fornecido contraceptivo oral antes da consulta de retorno puerperal. Se a orientação do serviço de saúde se preocupa com a anticoncepção, o contexto cultural da mulher vai além; pauta-se também no restabelecimento do organismo materno e no risco que o impacto da relação poderia gerar na cicatrização interna das suturas.

Fato que merece destaque é que, nesta sociedade, as mulheres têm consciência que a prática sexual deve ser evitada e, na maior parte das vezes, são apoiadas pelo companheiro. Cabe salientar que, dentre as puérperas, aquelas que não guardam a abstinência em todo o período puerperal sentem-se ansiosas, devido ao medo causado por terem quebrado uma regra imposta pelos saberes popular e profissional. A par de sua condição de mulher, essas puérperas sofrem pressão da sociedade e do grupo cultural para se enquadrarem no papel materno, o que as faz desvalorizar o lado mulher, para gerar um foco de atenção especial ao bebê e ao companheiro.

Ainda no mesmo domínio do Modelo de Competência Cultural de Purnell, destacamos os cuidados com o recém-nascido, com destaque para o uso da "faixinha" abdominal como forma protetiva do coto umbilical, prevenindo possíveis herniações. A maior parte dos cuidados com o recém-nascido é perpassada pelo meio sociocultural, representado pela família da mulher e por sua comunidade. Merece destaque, também, a ingesta de chá, dentre os quais, camomila e erva-doce, com o motivo de acalmar a criança, assim como ajudar nos desconfortos intestinais gerados pelas cólicas.

Observamos que, no período pós-parto, assim como em todo o ciclo gravídico-puerperal, os cuidados do binômio centram-se no modelo hospitalocêntrico, que fragmenta a mulher e seu neonato e não lhes garante um cuidado holístico, o que demonstra falta de competência cultural e o cuidado pautado apenas no modelo biomédico. 
Para o cuidado, a mulher considera padrões advindos socioculturalmente, que a torna protagonista do próprio cuidado; porém, em sintonia com o preconizado pelo seu meio cultural. Entender esta situação proporciona um cuidado individualizado por parte do cuidador de saúde, contribuindo para o cuidado integral da puérpera.

Outro domínio do Modelo de Competência Cultural de Purnell, que pode ser analisado à luz dos dados coletados, corresponde à "Espiritualidade".

Os dados mostraram que as puérperas, além de seguir um preceito religioso, mesmo que não praticantes, oram ou rezam, em especial pelo bem-estar do recémnascido. Essa prática da oração, na sua percepção, as ajuda a afastar os maus espíritos e a adquirir proteção para o binômio mãe-bebê.

Por outro dado, é extremamente reduzido o número de mulheres que não têm uma crença religiosa; embora seu contexto seja permeado por várias crenças, como evangélica, católica, testemunha de Jeová e espiritismo. Esta condição nos faz concordar com autores que realçam a necessidade de os profissionais incluírem, junto aos saberes científicos, os aspectos religiosos na atenção à mulher, em especial àquela que vivencia o puerpério.

Outro domínio do Modelo de Competência Cultural de Purnell que merece atenção frente aos dados desta pesquisa é intitulado como "Práticas de Cuidado à Saúde", que envolve as temáticas da automedicação, as crenças acerca do benzimento e as formas de cuidados culturais e biomédicos.

Para as mulheres sob estudo, o benzimento é uma maneira de curar e proteger o recém-nascido; consideram levar o bebê até uma benzedeira na tentativa de livrá-lo de um estado de mal-estar. A própria mãe toma a iniciativa pela prática transmitida de geração a geração. Também pode ocorrer de a criança ser levada à benzedeira por insistência de membros da rede familiar e social da puérpera diante de algum agravo à saúde.

Nesse grupo, o benzimento feito por telefone também é possível e o efeito esperado é o mesmo que o realizado na presença da criança. Em algumas situações, a benzedeira pode ser considerada como fonte de informação para o cuidado do recémnascido, uma vez que incentiva práticas de proteção e bem-estar da criança. 
Para essa população, a prática de benzimento é bem aceita, pois é realizada por alguém de confiança e que colabora para disseminação de práticas de cuidado, já que compartilha o mundo cultural semelhante aos da puérpera.

A automedicação é prática adotada por pequena parcela das mães sob estudo. Os medicamentos mais utilizados são os analgésicos e os antiespasmódicos, medicamentos que as puérperas reconhecem que não lhes causam danos no pósparto.

Por outro lado, as mulheres buscam na internet obter e confirmar informações referentes ao cuidado pós-natal. Dentre os temas de interesse, aqueles que envolvem cuidados com o recém-nascido e cuidados com o próprio corpo, como a busca por tratamentos estéticos. Essas puérperas utilizam, também, a internet para aprimorar seus cuidados no ciclo gravídico-puerperal.

Além de um evento recente, a internet teve larga expansão em consonância com a globalização, o que colaborou para novas formas de propagação de conhecimento, tanto que muitas informações estão relacionadas aos cuidados da saúde e aos sistemas médicos.

Tanto o suporte de sua rede sociocultural como a busca por auxílio pela internet ou nas redes sociais mostram que a puérpera passa por um ritual social, no qual existe a desconstrução da mulher para se tornar mãe, o que marca o início de uma nova vivência, que requer mudanças no cuidado e maior compromisso materno.

Frente às práticas de cuidado, pode-se verificar uma mescla de cuidados perpassados entre familiares, rede de contatos e profissionais. Além disso, os livros e os cursos oferecidos no meio eletrônico de informação, como a internet, são utilizados como forma de aprimorar o cuidado no período puerperal.

Por último, o domínio "Provedor de Cuidado à Saúde" relaciona-se aos provedores socioculturais, como redes de contato e familiares, além dos profissionais de saúde, com predominância no saber biomédico.

Primeiramente, verificamos que vários atores sociais e profissionais são responsáveis pela manutenção e pelo incremento dos cuidados da mulher no puerpério; dentre eles, encontramos: os familiares, os amigos e os vizinhos, seguidos dos profissionais e do conhecimento próprio. 
Pudemos compreender, por meio dos dados coletados, que a atuação do profissional, representado por médicos e enfermeiros, em sua maioria, ainda está extremamente arraigada ao saber biomédico.

As puérperas veem o profissional como alguém que deixa de dialogar com as clientes, por estar sempre apressado, o que prejudica o esclarecimento de suas dúvidas, pois não veem oportunidade para que possam questionar sobre sua saúde ou a de seu recém-nascido.

Os atores sociais são responsabilizados para complementar as lacunas abertas pela biomedicina ocidental. Dentre eles, destacamos os familiares, em especial as mães e as avós. Esse saber informal construído pelos familiares é bem aceito pelas puérperas deste estudo, pois os cuidadores tradicionais e a mulher fazem parte do mesmo contexto cultural e social.

As mulheres mais experientes, e que já vivenciaram os cuidados do ciclo gravídico-puerperal, geram nas novas mães um padrão mais alto de confiabilidade, principalmente bisavós e avós, pois demonstram conhecimentos e experiência que contribuem de forma concreta no processo da maternagem, além de terem visões de mundo semelhantes ao da puérpera, por viverem no mesmo ambiente cultural.

As sogras, como avó paterna, também desenvolvem os cuidados socioculturais; entretanto, verificamos maiores atritos na tríade mulher, companheiro e sogra, uma vez que esta é vista de maneira pejorativa, em alguns casos, pela puérpera, já que os vínculos são estabelecidos mais recentemente, ao contrário do que ocorre no caso da mãe e da avó materna.

O homem, no papel de pai, também procura prestar cuidados à puérpera e ao filho; entretanto, aguarda as demandas da puérpera para realizá-los. Isto ocorre, pois, historicamente, o cuidado é concebido entre mulheres e tende a ser passado de maneira intergeracional, das mães para as filhas, permanecendo no contexto feminino. O cuidado, focado na figura masculina, é mais um aspecto das transformações da sociedade que, no processo de globalização, procura dissipar questões de gênero imbricadas no cuidado no puerpério.

O serviço de saúde, pelos dados coletados, está voltado para os aspectos quantitativos da assistência, ou seja, na manutenção das consultas e orientações, esquecendo de envolver o contexto sociocultural da cliente, o que colabora para que 
esta busque solucionar seus questionamentos junto aos demais meios de informações, dentre eles: o próprio conhecimento através de vivências, família, amigos e internet.

Portanto, podemos compreender que o profissional de saúde precisa reformular e desconstruir as práticas biomédicas, para incorporar conhecimentos do mundo cultural da clientela, respeitando suas crenças e seus valores, para prestar-lhe cuidado culturalmente competente.

A partir do momento que a mulher não é atendida biopsicossocialmente, de forma que os cuidados se complementem, verificamos uma apreensão sobre qual cuidado seguir, o que colabora para replicação passiva de cuidados.

Por fim, verificamos que, para este grupo de puérperas, o advento da globalização está fortemente demarcado pelo acesso à internet, o que colabora para que a puérpera busque novas fontes de conhecimento - e busque, por meio destas, complementos às informações advindas de livros e saberes transmitidos pelos profissionais e comunidade.

A comunidade, na visão desta população, é representada pelas redes de contato que, em maior proporção, constituem-se de amigas e vizinhas, as quais se fazem presentes no momento do pós-parto, por meio da visita à puérpera e ao recémnascido. A prática cultural da visita viabiliza a transmissão de crenças e valores, por meio de conversas informais, uma vez que é exposta a experiência vivenciada por outras mulheres.

Podemos compreender que a visão cultural do cuidado na fase do puerpério mostra que as práticas adotadas pela mulher são realizadas com o intuito da manutenção da vida e, com frequência, atendem às normas impostas pela cultura da pessoa envolvida.

Para essas puérperas, várias são as fontes para obtenção e aprimoramento do cuidado materno no puerpério; entretanto, evidenciou-se que uma parcela replica o modelo ao qual é submetida, ou seja, apenas segue as orientações ditadas ora pelos profissionais de saúde, ora pelos familiares, sem ter consciência da opção por tal cuidado; enquanto outras seguem apenas as formas de cuidado que são perpassadas pelos mesmos sujeitos anteriores, mas que correspondem com a crença interiorizada da própria mulher. Assim, sabem ouvir e ponderar sobre as orientações recebidas, 
selecionando-as por meio de seu repertório de vida, de maneira consciente e responsável.

Entretanto, a falta de um cuidado culturalmente competente, que interligue as diversidades de saberes que atuam sobre a puérpera, pode influenciá-la na escolha por cuidado puerperal pouco congruente.

$* * *$

Consideramos como limitação deste estudo o fato de não ter abrangido a totalidade dos domínios do Modelo de Competência Cultural de Purnell, o que pode ter reduzido a ampla compreensão do Modelo, sugerindo que a teoria não tenha sido avaliada em sua totalidade. A justificativa para tal situação reside nos conteúdos dos relatos das puérperas, no recorte no período do puerpério e nas questões que nortearam o estudo, derivadas de seu objetivo. Assim, os domínios "Comunicação", "Ecologia biocultural" e "Rituais relativos à morte" não puderam ser analisados, pois seus temas não emergiram dos dados, o que impediu a ampla caracterização cultural do grupo, no recorte sob estudo, na perspectiva do Modelo adotado. De todo modo, cremos que esta situação não tenha prejudicado a compreensão das práticas de cuidado adotadas pelas puérperas atendidas na UBS de Rio Claro. 


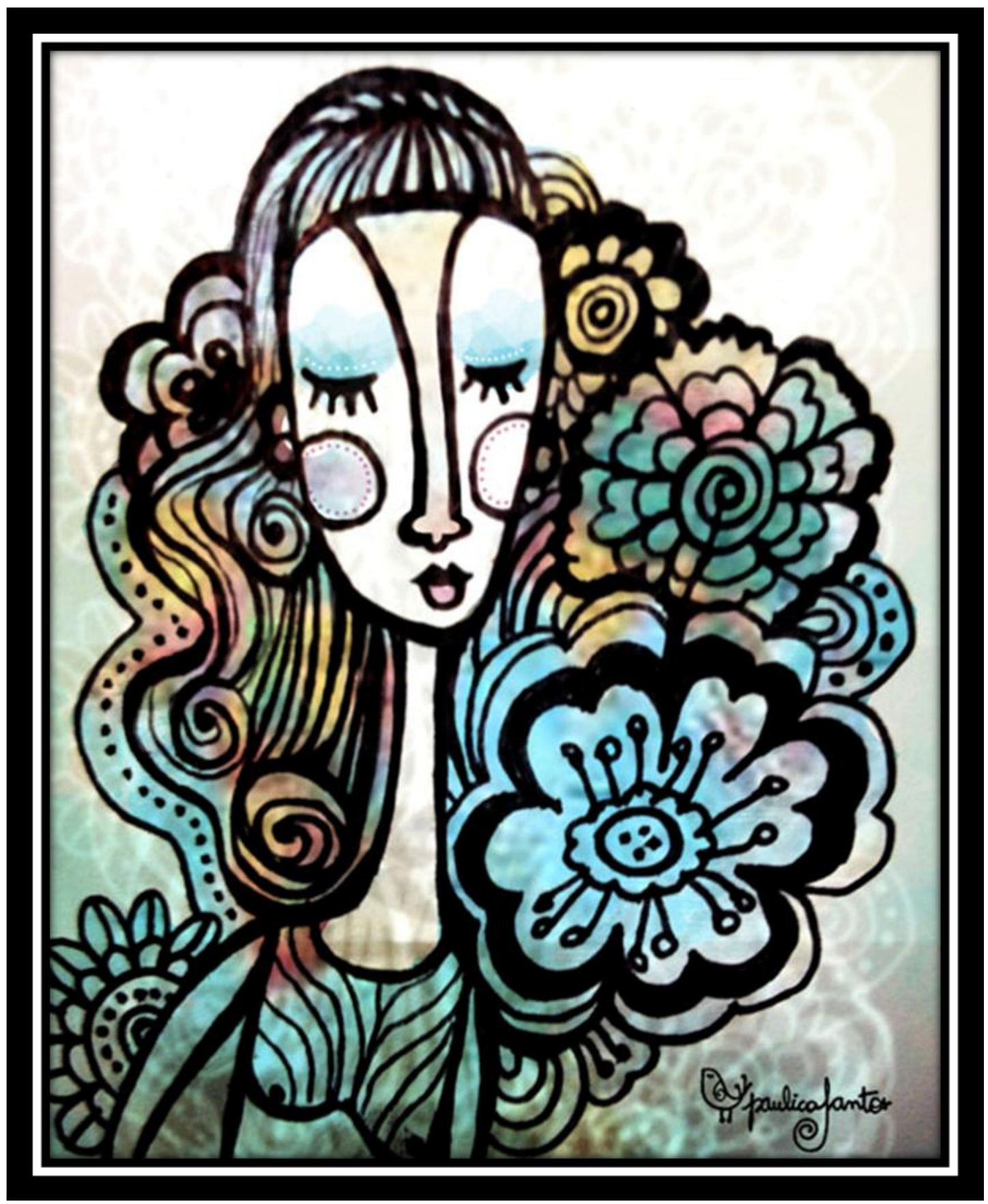

Fonte: http://paulicasantos.wordpress.com/

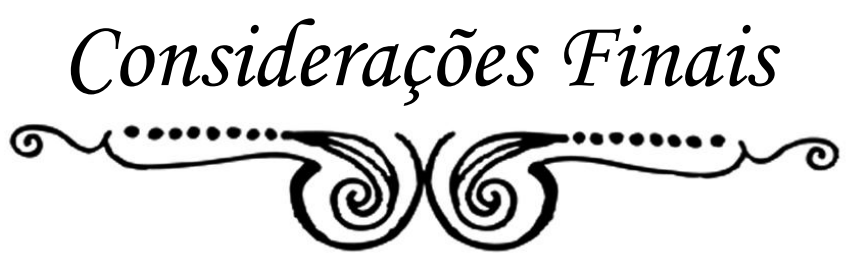


Neste estudo, o Modelo teórico adotado favoreceu a compreensão das ações da puérpera usuária de uma Unidade Básica de Saúde de Rio Claro, realizada durante sua fase puerperal. Mostrou a relação entre o aconselhamento originado do profissional de saúde e as práticas de origem cultural.

Vimos que o período pós-natal é permeado por crenças, que, na maior parte das vezes, são transmitidas no meio familiar, em especial, por mulheres de mais idade que já vivenciaram o ciclo gravídico-puerperal. Sob a ótica da puérpera, os aconselhamentos de práticas de cuidado transmitidos por sua rede familiar e de contato merecem respeito e devem ser seguidos durante o período pós-parto.

Sob esta ótica, os resultados mostraram a influência das crenças culturais sobre o cuidado no puerpério, transmitidas intergerações pelos cuidadores das redes familiar e cultural. Os cuidados prestados pelos profissionais de saúde são transmitidos tanto na UBS como na maternidade. Estes profissionais garantem sua presença, no contexto da mulher, por meio de orientações de práticas com enfoque no biológico, oferecidas de maneira verticalizada e, por vezes, fragmentada e divergente, o que demonstra sua dificuldade em acompanhar as influências culturais envolvidas no processo.

Portanto, ao explorar as práticas de cuidado adotadas pelas puérperas, verificamos que elas optam pelo cuidado oriundo de seu meio cultural, mas, sem se esquecer de algumas orientações perpassadas pelo profissional de saúde. Vale salientar, que as mulheres ainda buscam informações em sites da internet, com a intenção de aprimorar seu conhecimento, permitindo-lhe maior empoderamento frente as transformações desta fase do ciclo gravídico-puerperal. Também, muitas das práticas de cuidado que as puérperas adotam são voltadas ao bem-estar do recémnascido.

Sendo assim, a puérpera adota práticas de cuidado mistas, ou seja, mesclam os cuidados oriundos dos profissionais e os advindos da rede sociocultural; não obstante, a rede sociocultural tende a se sobressair nesta população, devido as lacunas deixadas pelo cuidado biomédico predominante em Rio Claro.

Frente às práticas de cuidado adotadas pela mulher, às suas fontes e às justificativas para adesão, consideramos a necessidade da readequação no cuidado orientado pelo profissional. Sendo assim, sugerimos a revisão do modelo de cuidado 
prestado pelos profissionais que atuam diretamente com as puérperas, dentre eles, os médicos e enfermeiras da rede primária de saúde, em especial na UBS, campo deste estudo, e na Maternidade Municipal para onde estas mulheres são encaminhadas no momento do parto.

Acreditamos que devam ser oportunizados momentos para reflexão do profissional para o rompimento de paradigmas. Sugerimos que os profissionais da saúde continuem prestando atenção, conforme as práticas baseadas em evidências do cuidado no pós-parto, mas que também se atentem para as formas de cuidados baseadas em sistema que priorize a visão integral e humanizada da mulher, pois, dessa forma, a mulher será empoderada e poderá decidir com segurança sobre a prática de cuidado que adotará no puerpério.

Com a intenção de aproximar o profissional de saúde do universo cultural da clientela, sugerimos a organização de estratégias participativas que propiciem momentos de reflexão, de modo a quebrar paradigmas, como o cuidado pautado unicamente no modelo biomédico, ampliando-o para um cuidado integral, biológico e voltado às crenças e aos valores da cliente e ao seu direito de escolha do cuidado.

Outro ponto que emergiu dos dados refere-se às orientações e às informações oferecidas às puérperas pelos profissionais de saúde, as quais demonstraram não alcançar totalmente seu objetivo junto à cliente. Na tentativa de reduzir esta lacuna, sugerimos a elaboração de um protocolo ou de um instrumento educativo único, elaborado pelos profissionais que integram o sistema de saúde da região, com o intuito de padronizar as orientações e os cuidados de saúde no pós-parto, com possibilidade de adaptação às necessidades de cada mulher. A atenção a esta demanda implica em uma visão ampliada do gestor de saúde do município, em conjunto com outros órgãos municipais. Porém, a curto prazo, esta atenção evitaria que a puérpera se visse entre diferentes orientações de cuidados, às vezes contraditórias, oferecidas pelos profissionais de saúde e sempre comparadas às do provedor de cuidado cultural. Em nosso entendimento, a atenção dada a esta proposta contribuiria para a redução da vulnerabilidade materna, pois favoreceria sua melhor aceitação das orientações geradas pelo profissional responsável pelo seu atendimento. 
Outra proposta que fazemos, com base nos resultados e no universo dos programas de saúde do país, relaciona-se à reelaboração do modelo de cuidado profissional oferecido pela Unidade Básica de Saúde. Nesse aspecto, propomos a incorporação de modelo baseado na Estratégia Saúde da Família. Nesta ótica, as equipes multidisciplinares colaborariam na integralidade da atenção à saúde, que agregaria os aspectos culturais na assistência à mulher no puerpério. $\mathrm{O}$ agente comunitário, como integrante das equipes, supriria as lacunas criadas pelo espaço de tempo entre as consultas puerperais, contribuindo com sua prática, de maneira individual, acolhedora e facilitada pela convivência na comunidade com a puérpera e sua família. A discussão de cada caso em particular, pelos membros da equipe de saúde, possibilitaria assistência prestada com confiabilidade e de modo culturalmente competente.

Além disso, o estímulo ao trabalho em equipe multidisciplinar, interdisciplinar ou transdisciplinar favoreceria a não fragmentação do sujeito junto ao modelo biomédico, o que reduziria as divergências de orientações entre os profissionais envolvidos neste cuidado.

Outra proposta para diminuir a distância verificada entre o profissional de saúde e o provedor de cuidado cultural relaciona-se à criação de grupos de educação em saúde - periódicos e com foco no puerpério. Neles, os profissionais de saúde atuariam como mediadores e repassariam os cuidados maternos e neonatais, por meio de diálogos com as puérperas e seus familiares. Este meio educativo se justifica pelo reduzido tempo destinado às consultas de pré-natal e de retorno puerperal, que prejudica o esclarecimento das dúvidas maternas e familiares. A atividade em grupo possibilitaria ao profissional exercer um cuidado complementar à consulta, além de favorecer maior contato com as puérperas e com os seus familiares, facilitando o cuidado culturalmente competente.

Um resultado que emergiu dos dados, embora não ligado diretamente aos objetivos deste estudo, mas que, a nosso ver, merece destaque para debates e estudos futuros envolvendo a cidade de Rio Claro e demais municípios do interior do estado, se deve ao elevado número de partos cesarianos encontrados: aproximadamente quatro vezes superior ao número preconizado pela Organização Mundial da Saúde. Lembramos que as mulheres tiveram parto em uma maternidade vinculada ao 
Sistema Único de Saúde, que prioriza o parto normal. Dessa situação, depreendemos que há falhas nas ações municipais e até estaduais para o incentivo do parto normal e humanizado. Acreditamos que a mudança de atitude do profissional e o convívio multidisciplinar no acompanhamento do ciclo gravídico-puerperal, com o compartilhamento do cuidado entre médicos, enfermeiras obstétricas e obstetrizes, contribuiriam para a redução do número de partos cesarianos na região.

Acreditamos que a criação de centros de parto normal também reduziria o número de partos operatórios, pois possibilitaria o cuidado centrado nos direitos das mulheres e favoreceria o cumprimento da legislação, que preconiza a presença de acompanhante no processo do parto, incorporando-o no momento do repasse de orientações de cuidado ao binômio mãe-bebê. Essa sugestão é concorde com o momento atual, no qual o país conta com propostas de criação de centros de parto, disponibilizando verbas e estratégias para a implementação desse sistema de atenção ao parto normal, em especial nas localidades que ainda têm ausência deste modelo de atenção.

Seguindo esta linha de pensamento, propomos, também, a inclusão do egresso de curso de Obstetrícia nos programas de saúde dos municípios, agregando este novo profissional ao cuidado da mulher e de seu recém-nascido. Ressaltamos que se trata de profissional, cuja formação se pauta no campo da assistência à saúde materna, com ênfase ao modelo de cuidado integral, que busca atender a mulher nas esferas biossocioculturais. Sua incorporação à equipe multidisciplinar contribuiria para a implementação de estratégias que colaborariam diretamente no cuidado integral e culturalmente competente à mulher e a seu neonato.

Finalizando, destacamos a necessidade da realização de novos estudos com abordagem no período puerperal, uma vez que a produção científica nesta área ainda é inferior à dos demais períodos do ciclo gravídico-puerperal, principalmente quando o foco recai nos aspectos socioculturais que o permeiam.

Do exposto, este estudo possibilitou a constatação de que crenças transmitidas em seu meio cultural permeiam e estarão presentes nas práticas de cuidado da mulher que vivencia o ciclo gravídico-puerperal - e o puerpério em particular. Nossas propostas pautam-se na interlocução entre os geradores de cuidados - profissionais de saúde, familiares e redes de contato materno - e a puérpera, de maneira que esta 
seja atendida de modo culturalmente competente. Portanto, ao ser esclarecida sobre as práticas de cuidado no puerpério, a mulher passa a ter condições de decidir e realizar o que lhe parecer conveniente e seguro, de forma esclarecida, e não apenas realizando passivamente os cuidados que lhe são repassados como conduta única, sem dar voz a sua vontade. 


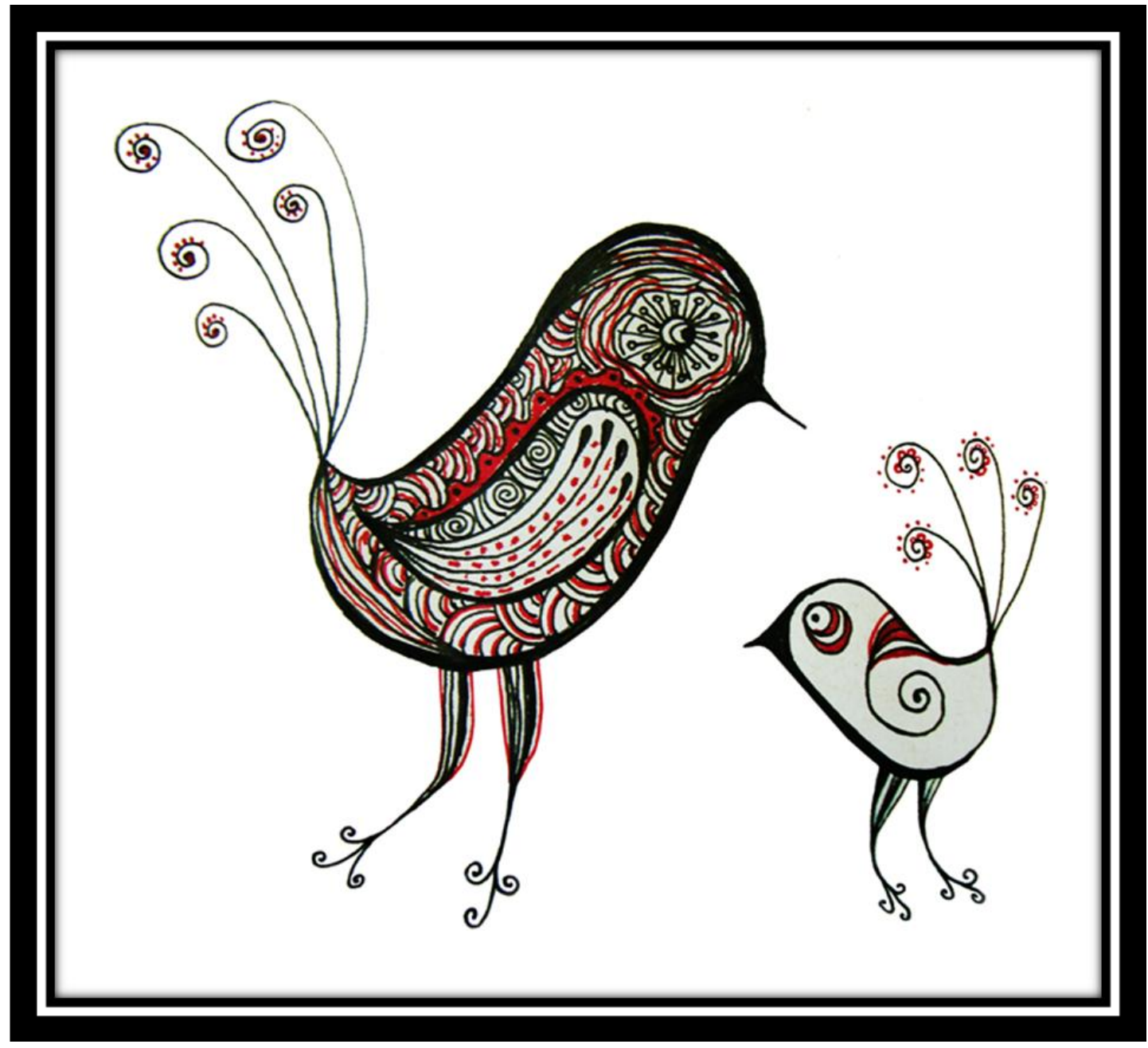

Fonte: http://paulicasantos.wordpress.com/

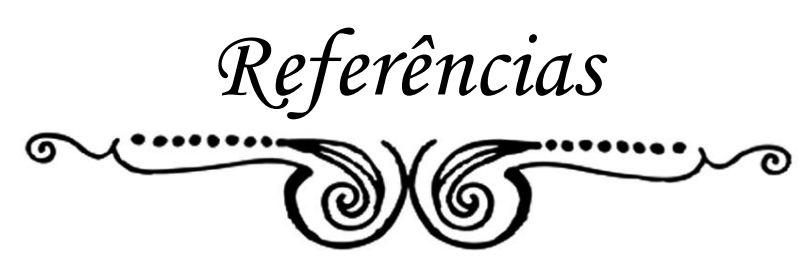


Akré J, editor. Alimentação infantil: bases fisiológicas [Internet]. São Paulo: IBFAN Brasil, OMS, OPAS, UNICEF; 1994. Lactação; [citado 2012 ago. 15]. p.10-26. Disponível em:

http://www.ibfan.org.br/documentos/ibfan/doc-288.pdf

Albers LL. Health problems after childbirth. J. Midwifery Womens Health. 2000; (45): $55-7$.

Almeida FDO, Kantorski LP. Convivendo com a mulher no período puerperal: uma abordagem cultural. Texto Contexto Enferm. 2000; 9(2):39-45.

Almeida JAG, Novak FR. Amamentação: um híbrido natureza-cultura. J Pediatr. 2004; 80(Sup15): 119-25.

Alvarez REC. O cuidado das crianças no processo saúde-doença: Crenças, valores e práticas nas famílias da cultura Kabano da Amazônia Peruana [tese na Internet]. São Paulo: Escola de Enfermagem, Universidade de São Paulo; 2012 [citado 2012 jul. 23]. 213 p. Disponível em:

http://www.teses.usp.br/teses/disponiveis/7/7141/tde-19042012-075829/pt-br.php

Alves AM, Gonçalves CSF, Martins MA, Silva ST, Auwerler TC, Zagonel IPS. A enfermagem e puérperas primigestas: Desvendando o processo de transição no papel materno. Cogitare Enferm [periódico na Internet]. 2007. [citado 2012 jun. 24]; 12 (4): 416-27. Disponível em:

http://ojs.c3sl.ufpr.br/ojs2/index.php/cogitare/article/download/10063/6918

Amaral RFC, Souza T, Melo TAP, Ramos FRS. Itinerário terapêutico no cuidado mãe-filho: interfaces entre a cultura e biomedicina. Rev René [periódico na Internet]. 2012. [citado 2012 ago. 21]; 13(1): 85-93. Disponível em:

http://www.revistarene.ufc.br/revista/index.php/revista/article/view/20/16

Andrade LCO, Santos MS, Aires JS, Joventino ES, Dodt RCM, Ximenes LB. Conhecimento de puérperas internadas em um alojamento conjunto acerca da higiene do neonato. Cogitare Enferm [periódico na Internet]. 2012. [citado 2012 jun. 24]; 17 (1): 99-105. Disponível em:

http://ojs.c3sl.ufpr.br/ojs2/index.php/cogitare/article/view/26381/17574

Aragaki IMM, Silva IA. Percepção de nutrizes acerca de sua qualidade de vida. Rev Esc Enferm USP [periódico na Internet]. 2011 [citado 2012 ago. 13] 45(1):71-8. Disponível em: http://www.scielo.br/pdf/reeusp/v45n1/10.pdf 
Araújo NM. É a vida de sempre: corpo e sexualidade no processo do nascimento [Tese na Internet]. São Paulo (SP): Escola de Enfermagem de São Paulo, Universidade de São Paulo; 2009 [citado 2011 fev. 15]. 185 p. Disponível em: http://www.teses.usp.br/teses/disponiveis/83/83131/tde-22062009-150305/pt-br.php

Argote LA, Vásquez ML. "La dieta" como camino para asegurar un hijo sano: una mirada desde el mundo urbano de las adolescentes. Colomb Méd [periódico na Internet]. 2005. [citado 2012 ago. 25]; 36(3 Supl 1):58-64. Disponível em: http://www.bioline.org.br/pdf?rc05053

Azeredo CM, Maia TM, Rosa TC, Fonseca e Silva F, Cecori PR, Cotta RMM. Percepção de mães e profissionais de saúde sobre o aleitamento materno: Encontro e desencontros. Rev Paul Pediatr [periódico na Internet]. 2008. [citado 2012 jul. 15]; 26(4): 336-44. Disponível em: http://www.scielo.br/pdf/rpp/v26n4/a05v26n4.pdf

Baião MR, Deslandes SF. Alimentação na gestação e puerpério. Rev Nutr [Periódico na Internet]. 2006 [citado 2010 ago. 08]; 19(2):245-53. Disponível em: http://www.scielo.br/pdf/rn/v19n2/a11v19n2.pdf

Baião MR, Deslandes SF. Práticas alimentares na gravidez: um estudo com gestantes e puérperas de um complexo de favelas do Rio de Janeiro (RJ, Brasil). Cienc Saúde Coletiva [periódico na Internet]. 2010. [citado 2012 ago. 23]; 15(2):3199-3206. Disponível em: http://www.scielo.br/pdf/csc/v15s2/a25v15s2.pdf

Barreira SMC, Machado FAS. Amamentação: compreendendo a influência do familiar. Acta Sci Health Sci. 2004; 1(1):11-20.

Bergamaschi SFF, Praça NS. Vivência da puérpera-adolescente no cuidado do recém-nascido, no domicílio. Rev Esc Enferm USP [periódico na Internet]. 2008 [citado 2012 jul. 15]; 42(3):454-60. Disponível em:

http://www.scielo.br/pdf/reeusp/v42n3/v42n3a05.pdf

Bitar MAF. Aleitamento materno: um estudo etnográfico sobre os costumes crenças e tabus ligados a esta prática [Dissertação]. Belém do Pará (PA): Centro de Ciências em Saúde, Departamento de Enfermagem da Universidade Federal do Pará; 1995. 
Boehs AE, Althoff CR, Elsen I, Nascimento MG.Crenças, condutas e cuidados no período grávido-puerperal das mulheres de uma comunidade pesqueira. Rev Ciênc Saúde.1993; 12(1):54-66.

Boer H, Lamxay V. Plants used during pregnancy, childbirth and postpartum healthcare in Lao PDR: A comparative study of the Brou, Saek and Kry ethnic groups. J Ethnobiol Ethnomed [serial on the Internet]. 2009 [cited 2010 ago. 8]; 5(25):14 telas. Available from:

http://www.ncbi.nlm.nih.gov/pmc/articles/PMC2749814/

Borges MR, Madeira LM, Azevedo VMGO. As práticas integrativas e complementares na atenção à saúde da mulher: Uma estratégia de humanização da assistência no hospital Sofia Feldman. Rev Min Enferm [periódico na Internet]. 2011 [citado 2012 ago. 08]; 15(1):105-113. Disponível em:

http://www.sofiafeldman.org.br/wp-content/uploads/2011/08/As-pr\%C3\%A1ticasintegrativas.pdf

Boscatto PC. Adesão da mãe às condutas de enfermagem na dermatite irritativa de fraldas do filho matriculado em uma Unidade de Saúde da Família [dissertação na Internet]. Guarulhos (SP): Curso de mestrado em Enfermagem, Universidade Guarulhos; 2007 [citado 2012 ago. 17]. 71 p. Disponível em:

http://tede.ung.br/tde_busca/arquivo.php?codArquivo $=41$

Brandão L, Smith V, Sperb TM, Parente MAMP. Narrativas intergeracionais. Psicol Reflex Crit. 2006; 19(1):98-105.

Brasil. Ministério da Saúde. Assistência pré-natal. Brasília; 2000.

Brasil. Ministério da Saúde. Parto, aborto e puerpério - Assistência humanizada à mulher. Brasília; 2001.

Brasil. Ministério da Saúde. Programa humanização do parto - Humanização no prénatal e nascimento. Brasília; 2002.

Brasil. Ministério da Saúde. Pré-natal e puerpério - Atenção qualificada e humanizada. Brasília; 2005.

Brasil. Ministério da Saúde. Saúde da criança: Nutrição Infantil, Aleitamento Materno e Alimentação Complementar. Brasília; 2009. 
Brasil. Ministério da Saúde. Amamentação e uso de medicamentos e outras substâncias. Brasília; 2010a.

Brasil. Ministério da Saúde (BR). SIS Pré-natal [Internet]. Brasília; DF: c.2008. [atualizado 2012 ago. 14; citado 2010b ago. 07]. Disponível em:

http://www.datasus.gov.br/sisprenatal/sisprenatal.htm

Brasil. Ministério da Saúde. Atenção à saúde do recém-nascido: Cuidados com o recém-nascido pré-termo. Brasília; 2011.

Cabral FB, Oliveira DLLC. Vulnerabilidade de puérperas na visão de Equipes de Saúde da Família: Ênfase em aspectos geracionais e adolescência. Rev Esc Enferm [periódico na Internet]. 2010 [citado 2010 ago. 08]; 44(2):368-75.Disponível em: http://www.scielo.br/pdf/reeusp/v44n2/18.pdf

Canaval GEE, Cruz DJB, Rosero DHS, Valencia MGC. La teoría de las transiciones y la salud de la mujer en el embarazo y en el posparto. Aquichán (Bogotá) [periódico na Internet]. 2007 [citado 2010 ago. 10]; 7(1):8-24. Disponível em:

http://www.scielo.org.co/scielo.php?script=sci_arttext\&pid=S1657-

59972007000100002\&lng=pt\&nrm=iso

Canesqui AM. A qualidade dos alimentos: Análise de algumas categorias da dietética popular. Rev Nutr [periódico na Internet]. 2007. [citado 2012 ago. 08]; 20(2):203-16. Disponível em: http://www.scielo.br/pdf/rn/v20n2/10.pdf

Canteiro EEL, Martins MFSV. A maternidade: Crenças e tradições em territórios amostra do distrito de Braga. O passado, o presente. Que futuro? [Internet]. In: Anais eletrônicos do Congreso Asociación de Demografia Histórica (ADEH); 2004 abr. 13; Granada, ESP. [citado 2010 mar. 15]. Disponível em:

http://www.ugr.es/ adeh/comunicaciones/Lopes_Canteiro_E_E.pdf

Cardoso ND, Pereira AV. Práticas interdisciplinares de acolhimento, educação em saúde e avaliação pós-parto em grupo de puérperas. Rev APS (Juiz de Fora) [Periódico na Internet]. 2010. [citado 2012 jul. 16]; 13(4):421-31. Disponível em: www.aps.ufjf.br/index.php/aps/article/download/1019/388

Castilho T. Painel: Família e Relacionamento de Gerações. In: Congresso Internacional Co-Educação de Gerações; 2003 out.; São Paulo, BR. [citado 2010 mar. 10]. Disponível em:

http://www.sescsp.org.br/sesc/imagem/upload/conferencias/94.rtf 
Castro E, Munõz SF, Plaza GP, Rodríguez M, Sepúlveda LJ. Práticas e crenças tradicionais do puerpério no município de Popayán. Revista Infancia, adolescência y família. 2006; 1(1):141-52.

Castro MBT, Kac G, Sichieri R. Padrão de consumo alimentar em mulheres no pósparto atendidas em um Centro Municipal de Saúde do Rio de Janeiro. Cad Saúde Pública [Periódico na internet]. 2006. [citado 2012 jun. 10]; 22(6):1159-70. Disponível em: http://www.scielo.br/pdf/csp/v22n6/05.pdf

Catafesta F, Venturi KK, Zagonel IPS, Martins M. Pesquisa-cuidado de enfermagem na transição ao papel materno entre as puérperas. REE [periódico na Internet]. 2007. [citado 2010 ago. 17]; 9(2): 457-75. Disponível em:

http://www.fen.ufg.br/revista/v9/n2/pdf/v9n2a13.pdf

Centa ML, Oberhofer PR, Chammas J. Puérpera vivenciando a consulta de retorno e as orientações recebidas sobre o puerpério. Fam Saúde Desenv. 2002; 4(1):16-22.

Chamilco RASI. Práticas culturais das parteiras tradicionais na assistência à mulher no período grávido-puerperal [tese na Internet]. Rio de Janeiro: Escola de enfermagem Anna Nery, Universidade Federal do Rio de Janeiro; 2004. [citado 2012 ago. 1]. 227 p. Disponível em:

http://teses.ufrj.br/eean_d/RosildaAlvesDaSilvaIslaChamico.pdf

Ciampo LA Del, Ricco RG, Ferraz IS, Daneluzzi JC, Martinelli Junior CE. Aleitamento materno e tabus alimentares. Rev Paul Pediatr. 2008; 26(4): 345-9.

Collière M-F. Promover a vida - Da prática das mulheres de virtude aos cuidados de enfermagem. Lisboa: Sindicato dos enfermeiros Portugueses; 1989. 385 p.

Costa MCG. Puerpério: a ambivalência das estratégias para o cuidado. Ribeirão Preto: Escola de Enfermagem de Ribeirão Preto, Universidade de São Paulo; 2001.

Cotta RMM, Priori SE, Marques ES. Mitos e crenças sobre o aleitamento materno. Revista Ciência e Saúde Coletiva da Associação Brasileira de Pós-graduação em Saúde coletiva. [periódico na Internet]. 2008 [citado 2010 mar. 19]. Disponível em: http://www.abrasco.org.br/cienciae.php?id_artigo=3241 
Crescer [homepage na Internet]. Rio de Janeiro; c 2002-2012 [atualizado 2012; citado 2012 jul. 28]. Disponível em:

http://revistacrescer.globo.com/EditoraGlobo/componentes/article/edg_article_print/ $\underline{1,3916,406045-2215-1,00 \cdot h t m l}$

Cunningham FG, MacDonald PC, Gant NF, Leveno KJ, Gilstrap LC, Gary Hankins DV et al. Williams Obstetrícia. Rio de Janeiro: Guanabara Koogan; 2000. O puerpério; p.465-76.

Diaz CMG, Hoffmann IC, Costenaro RGS, Soares RS, Silva BR, Lavall BC. Vivências educativas da equipe de saúde em unidade gineco-obstétrica. Cogitare Enferm. [periódico na Internet]. 2010. [citado 2012 ago. 15]; 15(2):364-7. Disponível em:

http://ojs.c3sl.ufpr.br/ojs-2.2.4/index.php/cogitare/article/view/17879/11668

Domingues RMSM, Hartz ZMA, Dias MAB, Leal MC. Avaliação da adequação da assistência pré-natal na rede SUS do Município do Rio de Janeiro, Brasil. Cad Saúde Pública [periódico na Internet]. 2012. [citado 2012 set. 29]; 28(3):425-37. Disponível em: http://www.scielosp.org/pdf/csp/v28n3/03.pdf

Enkin M, Keirse MJNC, Neilson J, Crowther C, Duley L, Hodnett E et al. Guia para atenção efetiva na gravidez e no parto. Rio de janeiro: Guanabara Koogan; 2005. p. 229- 241.

Evans R. Quarto estágio do trabalho de parto e período pós-parto. In: Orshan AS, organizadora. Enfermagem na saúde das mulheres, das mães e dos recém-nascidos: o cuidado ao longo da vida. Porto Alegre: Artmed; 2010. p.729-63.

Evenson KR, Aytur SA, Borodulin K. Physical activity beliefs, barriers, and enablers among postpartum women. Journal of Women's Healths [serial on the Internet]. 2009. [cited 2012 ago. 3]; 18(12): 1925-34. Available from:

http://www.ncbi.nlm.nih.gov/pmc/articles/PMC2828187/pdf/jwh.2008.1309.pdf

Farias DHR. Vivência de cuidado da mulher: A voz das puérperas [dissertação na Internet]. Rio Grande (RS): Programa Pós-graduação em enfermagem, Universidade Federal do Rio Grande; 2008 [citado 2012 ago. 13]. 83 p. Disponível em: http://www.dominiopublico.gov.br/download/texto/cp070972.pdf

Fleischer S. Sangue, Leite e Quarentena: Notas etnográficas sobre o puerpério na cidade de Melgaço, Pará. Campos: Revista de Antropologia Social [periódico na 
Internet]. 2007. [citado 2012 ago. 10]; 8(2):81-97. Disponível em: http://ojs.c3sl.ufpr.br/ojs2/index.php/campos/article/view/11169/7772

G1. Marcha pelo parto humanizado atrai mães, pais e bebês em Araraquara [Internet]. Rio de Janeiro; c. 2002-2012 [atualizado 2012 ago. 8; citado 2012 set 01]. Disponível em: http://g1.globo.com/sp/sao-carlos-regiao/noticia/2012/08/marchapelo-parto-humanizado-atrai-maes-pais-e-bebes-em-araraquara.html

Geçkil E, Sahin T, Ege E. Traditional postpartum practices of women and infants and the factors influencing such practices in South Eastern Turkey. Midwifery [serial on the Internet]. 2009. [cited 2012 ago. 16]; 25(1):62-71. Available from: http://ac.elscdn.com/S0266613807000046/1-s2.0-S0266613807000046main.pdf? tid=9f9df018-08dc-11e2-bd85-

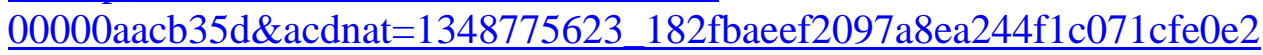

Grimal P. Mitologia Clássica: mitos, deuses e heróis. Lisboa: Texto e Grafia; 2009. $160 \mathrm{p}$.

Grupo jornal cidade. Santa Casa realizou mais partos normais [Internet]. Rio Claro; c.2012. [atualizado 2008 jul. 27; citado 2010 ago. 09]. Disponível em: http://jornalcidade.uol.com.br/rioclaro/dia-a-dia/saude/25892-Santa-Casa-realizou$\underline{\text { mais-partos-normais }}$

Gualda DMR. Eu conheço minha natureza: um estudo etnográfico da vivência do parto [Tese]. São Paulo(SP): Escola de Enfermagem, Universidade de São Paulo; 1993.

Gualda DMR, Bergamasco RB. Enfermagem, cultura e o processo saúde-doença. São Paulo: Ícone Editora; 2004. 352 p.

Heh SS. "Doing the month" and Social Support". Fu-Jen J of Med [periódico na Internet]. 2004. [citado 2010 out. 16]; 2(2): 11-6. Disponível em: http://www.mc.fju.edu.tw/userfiles/file/Med\%20Journal/Vol.2\%20No.2/\%E8\%BC\% 94\%E5\%A4\%A72\%E5\%8D\%B72\%E6\%9C\%9F-02.pdf

Helman CG. Cultura, saúde e doença. Porto Alegre: Artes Médicas; 1994. 333 p.

Helman CG. Cultura, saúde e doença. Porto Alegre, Artes Médicas; 2003. 408 p. 
Helman CG. Cultura, saúde e doença. Porto Alegre, Artes Médicas; 2009. 432 p.

Henriques MIG, Gomes IC. Mito familiar e transmissão psíquica: uma reflexão temática de forma lúdica. Psychê. 2005; 16:183-196.

Hizel S, Ceyhun G, Tanzer F, Sanli C. Traditional beliefs as forgotten influencing factors on breast-feeding performance in Turkey. Saudi Med J [serial on the Internet]. 2006. [cited 2012 jul. 16]; 27(4): 511-8. Available from: http://www.smj.org.sa/PDFFiles/Apr06/13Tradition20051281.pdf

Holanda AB. Mini Aurélio: O dicionário da língua portuguesa - reforma ortográfica. Nacional: Positivo; 2004.

Ichisato SMT, Shimo AKK. Revisitando o desmame precoce através de recortes da história. Rev Latino-Am Enfermagem [periódico na Internet]. 2002. [citado 2012 ago. 15]; 10(4):578-85. Disponível em:

http://www.scielo.br/pdf/rlae/v10n4/13371.pdf

Ichisato SMT, Shimo AKK. Vivência da amamentação: lactogogos e rede de suporte. Cienc Cuid Saude. 2006; 5(3):355-62.

Iliyasu Z, Kabir M, Galadanci HS, Abubakar IS, Salihu HM, Aliyu MH. Postpartum beliefs and pratices in Danbare village, North Nigéria. Journal of Obstetrics \& Gynaecology [serial on the Internet]. 2006. [cited 2012 ago. 17]; 26(3): 211-15:

http://ac.els-cdn.com/S0266613807000046/1-s2.0-S0266613807000046-

main.pdf? tid=11e4025c-08dd-11e2-8a3c-

00000aab0f02\&acdnat $=1348775815 \_$f85ff $3980385 f b c 5138 \mathrm{e} 206 \mathrm{c} 12118972$

Instituto Brasileiro de Geografia e Estatística (IBGE). IBGE Cidades [Internet]. 2009a [citado 2010 ago. 09]. Disponível em:

http://www.ibge.gov.br/cidadesat/painel/painel.php?codmun=354390\#

Instituto Brasileiro de Geografia e Estatística (IBGE). Nascimentos no Brasil: O que dizem as informações? [Internet]. 2009b [citado 2012 jul. 15]. Disponível em: http://www.ibge.gov.br/home/estatistica/populacao/indic_sociosaude/2009/com_nasc . $\mathrm{pdf}$

Iserhard ARM, Budó MLD, Neves ET, Badke MR. Práticas culturais de cuidados de mulheres mães de recém-nascido de risco do sul do Brasil. Esc Anna Nery Rev 
Enferm [periódico na Internet]. 2009. [citado 2012 jul. 08]; 13(1):116-22. Disponível em: http://www.scielo.br/pdf/ean/v13n1/v13n1a16.pdf

Jackson D. Maternidade: uma experiência sem fronteiras (Ser mãe). São Paulo: Publifolha; 2006. 128 p.

Junges CF, Ressel LB, Budó MLD, Padoin SMM, Hoffmann IC, Sehnem GD. Percepções de puérperas quanto aos fatores que influenciam o aleitamento materno. Rev Gaúcha Enferm [periódico na Internet]. 2010. [citado 2012 ago. 22];31(2):34350. Disponível em: http://www.scielo.br/pdf/rgenf/v31n2/20.pdf

Kalinowski L, Lenardt M, Mazza V, Lacerda M, Parede M. Crenças e práticas populares durante o período pós-parto: revisão integrada das produções de enfermagem. REE [periódico na Internet]. 2010. [citado 2011 mar. 01]; 9(3). Disponível em:

http://www.objnursing.uff.br/index.php/nursing/article/view/j.1676-4285.2010.3140

Kalinowski LC. Vivência do cuidado pela puérpera primípara no contexto domiciliar: olhar da enfermeira [dissertação na Internet]. Curitiba: Setor Ciências da Saúde, Universidade Federal do Paraná; 2011 [citado 2012 ago. 5]. 141 p. Disponível em:

http://www.ppgenf.ufpr.br/DISSERTA\%C3\%87\%C3\%83OLU\%C3\%8DSACANES TRAROKALINOWSKI.pdf

Kassar SB, Lima MC, Albuquerque MFM, Barbieri MA, Gurgel RQ. Comparações das condições socioeconômicas e reprodutivas entre mães adolescentes e adultas jovens em três maternidades públicas de Maceió, Brasil. Rev Bras Saúde Matern Infant [periódico na Internet]. 2006. [citado 2012 jul. 15]; 6(4): 397-403. Disponível em: http://www.scielo.br/pdf/rbsmi/v6n4/06.pdf

Kleinman A. Patients and healers in the context of culture. Los Angeles: University of California Press, 1980. p. 50-70

Kitzinger S. Mães: um estudo antropológico da maternidade. Lisboa: Editorial Presença; 1978. 240 p.

Lang JB, Elkin ED. A study of the beliefs and birthing practices of traditional midwives in rural Guatemala. Journal of Nurse-Midwifery [serial on the Internet]. 1997 [cited 2012 jul. 15]; 42(1): 25-31. Available from: http://ac.elscdn.com/S0091218296000699/1-s2.0-S0091218296000699- 
main.pdf?_tid=ec30f190-08dd-11e2-9e93-

$\underline{00000 \text { aacb35e\&acdnat }=1348776181 \_67813709564 d f 7 e d 27 d 74 e e 48 f e 98407}$

Lefèvre F, Lefèvre NA, Teixeira JJV. O discurso do sujeito coletivo: Uma nova abordagem metodológica em pesquisa qualitativa. Caxias do Sul: EDUSC; 2000. $138 \mathrm{p}$.

Lefèvre F, Lefèvre AN. Depoimentos e Discursos: uma proposta de análise em pesquisa social. Brasília: LiberLivro; 2005. 97 p.

Lefèvre F, Lefèvre AN. O sujeito coletivo que fala. Interface: Comunic, Saúde, Educ [periódico na Internet]. 2006. [citado 2012 fev. 25]; 10(20):517-24. Disponível em: http://www.scielo.br/pdf/icse/v10n20/17.pdf

Liu N, Limei M, Xiufa S, Liegang L, Ping Y, Banghua C. The effect of health and nutrition education intervention on women's postpartum beliefs and practices: a randomized controlled trial. BMC Public health [serial on the Internet]. 2009 [cited 2010 dec. 15]; 9(45): 9 telas. Available from:

http://www.ncbi.nlm.nih.gov/pmc/articles/PMC2640472/pdf/1471-2458-9-45.pdf

Lundberg PC, Thu TTN. Vietnamese women's cultural beliefs and practices related to the postpartum period. Midwifery [serial on the Internet]. 2011 [cited 2012 aug. 5]; 27(2011): 731-6. Available from: http://ac.els-cdn.com/S0266613810000252/1s2.0-S0266613810000252-main.pdf? tid=b961a9f0-08e0-11e2-ae00$\underline{00000 a a c b 360 \& a c d n a t=1348777385 \_6 c 6577 \mathrm{a} 471 \mathrm{fbee} 5 \mathrm{a} 987 \mathrm{f} 921 \mathrm{bde} 0 \mathrm{ded} 26}$

Luz AMH, Berni NIO, Selli L. Mitos e tabus da maternidade: um enfoque sobre o processo saúde-doença. Rev Bras Enferm. 2007; 60(1): 42-8.

Marchi MM, Sztajn R. Autonomia e heteronomia na relação entre profissional de saúde e usuário dos serviços de saúde. Bióetica [periódico na Internet]. 1998. [citado 2012 ago. 22]; 6(1):39-45. Disponível em:

http://revistabioetica.cfm.org.br/index.php/revista_bioetica/article/view/322/390

Marques ES, Cotta RMM, Magalhães KA, Sant'Ana LFR, Gomes AP, SiqueiraBatista R. A influência da rede social da nutriz no aleitamento materno: o papel estratégico dos familiares e dos profissionais de saúde. Cienc Saúde Coletiva [periódico na Internet]. 2010. [citado 2012 ago. 20]; 15(1):1391-1400. Disponível em:

http://www.scielo.br/pdf/csc/v15s1/049.pdf 
Marques ES, Cotta RMM, Botelho MIV, Franceschini SCC, Araújo RMA. Representações sociais sobre a alimentação da nutriz. Cienc Saúde Coletiva [periódico na Internet]. 2011 [citado 2012 ago. 3]; 16(10):4267-72. Disponível em: http://www.scielo.br/pdf/csc/v16n10/a32v16n10.pdf

Marroni D. O processo saúde-doença em uma comunidade indígena: A história oral do habitante do mato. São Paulo: Escola de Enfermagem, Universidade de São Paulo; 2002.

Matijasevich A, Santos IS, Silveira MF, Domingues MR, Barros AJD, Marco PL et al. Inequities in maternal postnatal visits among public and private patients: 2004 Pelotas cohort study. BMC Public health [serial on the Internet]. 2009 [cited 2012 aug. 3]; 9(335): 10 telas. Available from:

http://www.biomedcentral.com/content/pdf/1471-2458-9-335.pdf

Martins ADM, Martins EF. Assistência de enfermagem domiciliar no puerpério para garantir sucesso no aleitamento materno: relato de caso. Rev Bras Ciênc Saúde [periódico na Internet]. 2008. [citado 2012 set. 10]; 15: 82-93. Disponible em:

http://seer.uscs.edu.br/index.php/revista_ciencias_saude/article/viewFile/543/389

Martins AA. É importante a espiritualidade no mundo da saúde?. São Paulo: Paulus; 2009. p. 13-31

Medina IA, Mayca J. Creencias y costumbres relacionadas con el embarazo, parto y puerperio en comunidades nativas Awajun y Wampis. Rev Peru Med Exp Salud Publica [periódico na Internet]. 2006 [citado 2010 dez. 10]; 23(1):22-32. Disponível em:

http://www.scielo.org.pe/scielo.php?script=sci_arttext\&pid=S1726$\underline{46342006000100004 \& \operatorname{lng}=\text { es\&nrm=iso\&tlng=es }}$

Melo CRM. Parto: Mitos construídos, mitos em construção. Bauru: EDUSC; 2003. $89 \mathrm{p}$.

Merighi MAB, Gonçalves R, Rodrigues IG. Vivenciando o período puerperal: uma abordagem compreensiva da Fenomenologia Social. Rev Bras Enferm. 2006; 59(6): 775-9.

Monteiro LC. Representações sociais de puérperas sobre o cuidado de si e o cuidado de enfermagem no alojamento conjunto [dissertação na Internet]. Fortaleza: Centro 
de Ciências da Saúde, Universidade Estadual do Ceará; 2011 [citado 2012 ago. 7]. 73p. Disponível em:

http://www.uece.br/cmacclis/dmdocuments/lidiane_colares_monteiro.pdf

Monteiro A, Ribeiro A, Costa E, Pereira I, Cruz I, Cruz P. A visão da mulher na antropologia: mitos da criação e crenças em relação à gravidez. Millenium: Revista do ISPV [periódico da Internet]. 2004. [citado 2012 ago. 15]; 30:38-42. Disponível em: http://www.ipv.pt/millenium/Millenium30/4.pdf

Moura ECD. Eu te benzo, eu te livro, eu te curo: nas teias do ritual de benzeção. MNEME: Revista de humanidades [periódico na Internet]. 2011. [citado 2012 set. 10]; 11(29): 340-69. Disponível em:

http://www.periodicos.ufrn.br/index.php/mneme/article/view/980/964

Nakamura E, organizadora; Martin D, organizadora; Santos JFQ, organizador. Antropologia para enfermagem. São Paulo: Manole; 2009. 143p.

Nakano AMS, Stefanello J, Gomes FA, Mamede FV. O cuidado no "resguardo": as vivências de crenças e tabus por um grupo de puérperas. Rev Bras Enferm. 2003; 53(3): 242-7.

Nakano AMS, Reis MCG, Pereira MJB, Gomes FA. O espaço social das mulheres e a referência para o cuidado na prática da amamentação. Rev Latino-am Enfermagem [periódico na Internet]. 2007. [citado 2012 ago. 20]; 15(2):10 laudas. Disponível em: http://www.scielo.br/pdf/rlae/v15n2/pt_v15n2a07.pdf

Neme B. Obstetrícia básica. São Paulo: Sarvier; 2000. 1379 p.

Neto ETS, Leal MC, Oliveira AE, Zandonade E, Gama SGN. Concordância entre informações do Cartão da Gestante e da memória materna sobre assistência pré-natal. Cad. Saúde Pública (RJ) [periódico na Internet]. 2012. [citado 2012 ago. 10]; 28(2):256-66. Disponível em: http://www.scielo.br/pdf/csp/v28n2/05.pdf

Noale NA. Queda na taxa de fecundidade. Grupo jornal cidade de Rio Claro [periódico na internet]. 2011 ago. 21 [citado 2012 jun. 26]. Disponível em: http://jornalcidade.uol.com.br/rioclaro/dia-a-dia/saude/80471

Oliveira FG. E depois do parto? Cuidados com o corpo, a mente e a vida sexual. São Paulo: Ideia e ação; 2006.143 p. 
Osava RH. Assistência ao parto no Brasil: o lugar do não médico [Tese]. São Paulo(SP): Faculdade de Saúde Pública, Universidade de São Paulo; 1997.

Osman H, Zein LE, Wick L. Cultural beliefs that may discourage breastfeeding among Lebanese women: a qualitative analysis. Int Breastfeed $\mathbf{J}$ [serial on the Internet]. 2009 [cited 2012 jul. 29]; 4(12): 6 telas. Available from:

http://www.ncbi.nlm.nih.gov/pmc/articles/PMC2774667/pdf/1746-4358-4-12.pdf

Pátaro CSO. Pensamento, crenças e complexidade humana. Cien Cogn [periódico da Internet]. 2007. [citado 2010 mar. 15]; (12):134-49. Disponível em:

http://www.cienciaecognicao.org

Pedroso MEM. Crenças relacionadas com a gestação e puerpério [Dissertação]. São Paulo (SP): Escola de Enfermagem de São Paulo, Universidade de São Paulo; 1982.

Pedroso R. "Nova" classe média ganha até R\$ 1.019 per capita (Valor Econômico, em 30.05.2012). SAE na mídia [periódico na Internet]. 2012 mai 30 [citado 2012 ago. 13]. Disponível em: http://www.sae.gov.br/site/?p=12060

Pelcastre B. Pregnancy, delivery and puerperium: beliefs and practices of midwives in San Luis Potosi, Mexico. Rev Esc Enferm USP [periódico da Internet]. 2005 [citado 2010 mar. 15]; 39(4):375-82. Disponível em:

http://www.scielo.br/scielo.php?script=sci_arttext\&pid=S0080$\underline{62342005000400002 \& \text { lang }=p t}$

Penna LHG, Carinhanha JI, Rodrigues RF. A mulher no pós-parto domiciliar: Uma investigação sobre essa vivência. Esc Anna Nery Rev Enferm [periódico na Internet]. 2006. [citado 2012 ago. 10]; 10 (3): 448-55. Disponível em:

http://www.scielo.br/pdf/ean/v10n3/v10n3a13.pdf

Pinelli FGS. Conhecimentos e opiniões de mães sobre alguns aspectos do puerpério [dissertação]. São Paulo: Escola Paulista de Medicina, Universidade Federal de São Paulo; 1988.

Piperata BA. Forty days and forty nights: a biocultural perspective on postpartum practices in the Amazon. Soc Sci Med [periódico na Internet]. 2008 [citado 2010 ago. 15]; 67(7):1094-103. Disponível em:

http://anthropology.osu.edu/docs/faculty/Piperata_SSM_2008.pdf 
Purnell L. A description of the Purnell Model for Cultural Competence. J Transcult Nurs. 2000; 11(1):40-46.

Purnell L. The Purnell Model for Cultural Competence. J Multicult Nurs Health [serial on the Internet]. 2005. [cited 2012 apr. 7]; 11(2): 7-15. Available from: http://www.midwestclinicians.org/sharedchcpolicies/Policies_Forms/Cultural\%20Co mpetency/PURNELL'S\%20MODEL.pdf

Purnell L, Davidhizar RE, Giger JN, Strickland OL, Fishman D, Allison DM. A guide to developing a culturally competent organization. J Transcult Nurs. 2011; 22 (1): 7-14.

Rapoport A, Piccinini CA. Apoio social e experiência da maternidade. Rev Bras Crescimento Desenvolv Hum [periódico na Internet]. 2006. [citado 2010 mar. 29]; 16(1):85-96. Disponível em:

http://www.revistasusp.sibi.usp.br/pdf/rbcdh/v16n1/09.pdf

Ravelli APX. Consulta puerperal de enfermagem: uma realidade na cidade de Ponta Grossa, Paraná, Brasil. Rev Gaúcha Enferm [periódico na Internet]. 2008. [citado 2012 ago. 21]; 29(1):54-9. Disponível em:

http://seer.ufrgs.br/RevistaGauchadeEnfermagem/article/view/5264/2998

Raven JH, Chen Q, Tolhurst RJ, Garner P. Traditional beliefs and practices in the postpartum period in Fujian Province, China: a qualitative study. BMC Pregnancy Childbirth [serial on the Internet]. 2007. [cited 2010 dec. 08]; 7(8): 11 laudas. Available from:

http://www.ncbi.nlm.nih.gov/pmc/articles/PMC1913060/?tool=pubmed

Rego JD, Lopes PRA, Ventura WP. As dúvidas mais comuns entre as mães e seus familiares. In: Rego LD, editor. Aleitamento Materno - Um guia para pais e familiares. São Paulo: Atheneu; 2008. p. 387-8.

Rezende MA, Sigaud CHS, Veríssimo MLR, Chiesa AM, Bertolozzi MR. O processo de comunicação na promoção do aleitamento materno. Rev. Latino-Am. Enferm [periódico na Internet]. 2002. [citado 2012 ago. 22]; 10(2): 234-8. Disponível em: http://www.scielo.br/pdf/rlae/v10n2/10520.pdf 
Rice PL. Nyo dua hli- 30 days confinement: Traditions and changed childbearing beliefs and practices among Hmong women in Australia. Midwifery [serial on the Internet]. 2000. [cited 2012 jul. 21]; 16:22-34. Available from: http://ac.elscdn.com/S0266613899901808/1-s2.0-S0266613899901808-

main.pdf? tid=fc0c451a-08e2-11e2-9b67-

$\underline{00000 a a b 0 f 6 c \& a c d n a t=1348778355 \_2 \mathrm{fa} 6803 \mathrm{dc} 440 \mathrm{f} 3738 \mathrm{~d} 5 \mathrm{f} 7866 \mathrm{~d} 79022 \mathrm{a} 3}$

Rico DAP. Cuidado de las puérperas en el siglo XXI. Av enferm [periódico na Internet]. 2006. [citado 2010 dez. 08]; 24(2):6-12. Disponível em:

http://www.enfermeria.unal.edu.co/revista/articulos/xxiv2_1.pdf

Rigo K, Neves CS. Alimentação da puérpera: Crenças, mitos e verdades. In: II SECNUTRI - Seminário Científico do curso de nutrição; 2012 mai 18-19; Foz do Iguaçu, PR. Uniamérica-PR; 2012 [citado 2012 ago. 10]. Disponível em: http://revista.uniamerica.br/index.php/secnutri/article/view/84/74

Rio Claro (São Paulo). Secretaria Municipal de Saúde de Rio Claro. Atenção à saúde [Internet]. Rio Claro, SP: Prefeitura de Rio Claro; 2012 [citado 2012 set. 10]. Disponível em: http://www.saude-rioclaro.org.br/UBS/atencao\%20a\%20saude.htm

Rodrigues AC. Buscando raízes. Horizontes Antropológicos [periódico na Internet]. 2001. [citado 2012 set. 05]; 7(16):131-44. Disponível em:

http://www.scielo.br/pdf/ha/v7n16/v7n16a07.pdf

Salim NR, Araújo NM, Gualda DMR. Corpo e sexualidade: a experiência de um grupo de puérperas. Rev Latino-Am Enfermagem [periódico na Internet]. 2010. [citado 2012 ago. 17];18(4): 8 telas. Disponível em:

http://www.scielo.br/pdf/rlae/v18n4/pt_11.pdf

Salve JM, Silva IA. Representações sociais de mães sobre a introdução de alimentos complementares para lactentes. Acta Paul Enferm [periódico na Internet]. 2009. [citado 2011 abr. 15]; 22 (1): 43-8. Disponível em:

http://www.scielo.br/pdf/ape/v22n1/a07v22n1.pdf

Sandre-Pereira G, Colares LGT, Carmo MGT, Soares EA. Conhecimentos maternos sobre amamentação entre puérperas inscritas em programa de pré-natal. Cad. Saúde Pública [periódico na Internet]. 2000. [citado 2012 ago. 6]; 16(2):457-66. Disponível em: http://www.scielo.br/pdf/csp/v16n2/2095.pdf 
Scarpa GF. Medicinal plants used by the Criollos of Northwestern Argentine Chaco. J Ethnopharmacology [serial on the Internet]. 2004. [cited 2012 aug. 10]; 91(2004): 115-35. Available from: http://ac.els-cdn.com/S0378874103004446/1-s2.0S0378874103004446-main.pdf? tid=abef7d6a-08e5-11e2-86eb$\underline{00000 a a b 0 f 6 b \& a c d n a t=1348779510 \_c 1 d 61 f 76 a 680 a c 7 c 38 c 48 a 3980628571}$

Scarso IS, Porto E, Canniatti-Brazaca SG. Correlação entre frequência alimentar de lactantes e acidez no leite de um banco de leite humano. Alim Nutr [periódico da Internet]. 2009. [citado 2012 ago. 4]; 20(2): 301-5. Disponível em: http://serv-bib.fcfar.unesp.br/seer/index.php/alimentos/article/viewArticle/1061

SEADE. Fundação Sistema Estadual de Análise de Dados. Perfil municipal Condições de vida [Internet]. São Paulo, SP: Fundação SEADE, 2011 [citado 2012 ago. 20]. Disponível em:

http://www.seade.gov.br/produtos/perfil/perfilMunEstado.php

Sich D. Traditional concepts and customs on pregnancy, birth and post partum period in rural Korea. Soc Sci \& Med [serial on the Internet]. 1981. [cited 2012 ago. 7]; 15(b): 65-9. Available from: http://ac.els-cdn.com/0160798781900107/1-s2.00160798781900107-main.pdf? tid=4b618e42-08e6-11e2-8ebd-

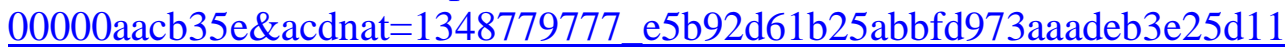

Silva LR, Christoffel MM, Castro SJ, Ribeiro F. A prática do cuidado prestado pelas mulheres aos filhos no domicílio. Enfermaría Global [periódico na Internet]. 2007. [citado 2012 ago. 21]; 10: 9 laudas. Disponível em:

https://docs.google.com/viewer?a=v\&q=cache:kFugAZBvYKIJ:revistas.um.es/eglob al/article/view/207/244+a+pr\%C3\%A1tica+do+cuidado+prestado\&hl=ptBR\&gl=br\&pid=bl\&srcid=ADGEEShrWKAlFAGzByNDcE1HTEqc9FzeFQidMBS r3RLPeWjXX_19YkSEzdnufV0nB7SqPN6b_D4a1Zl3sYlkSq_DlRrhmt9LqCkUbTv ItoWh01UCsnZ7Doq616z9ug4ACuzrAGtL-

JF\&sig=AHIEtbSb9Ek8qs1DuApPWRuolRGY-wM-TQ

Silva LA, Nakano AMS, Gomes FA, Stefanello J. Significados atribuídos por puérperas adolescentes à maternidade: autocuidado e cuidado com o bebê. Texto Contexto Enferm [periódico na Internet]. 2009. [citado 2012 ago. 14]; 18(1): 48-56. Disponível em:

http://www.scielo.br/pdf/tce/v18n1/v18n1a06.pdfhttp://www.scielo.br/pdf/tce/v18n1/ v18n1a06.pdf

Silva RV, Silva IA. A vivência de mães de recém-nascidos prematuros no processo de lactação e amamentação. Esc Anna Nery Rev Enferm [periódico na Internet]. 2009. [citado 2011 abr. 15]; 13 (1): 108-115. Disponível em: 
http://www.scielo.br/pdf/ean/v13n1/v13n1a15.pdf

Silva SLC, Roldán MDCB. Adolescentes em puerpério y sus práticas de cuidado. Av Enferm [periódico na Internet]. 2009. [citado 2010 dez. 08]; 27(2): 82-91. Disponível em: http://www.enfermeria.unal.edu.co/revista/articulos/xxvii2_9.pdf

Silva JLCP, Surita FGC. Idade materna: resultados perinatais e via de parto [editorial]. Rev Bras Ginecol Obstet. 2009; 31(7):321-5.

Shimo AKK, Nakano AMS. Adaptações psico-física e social no puerpério: Uma reflexão. Acta Paul Enferm. 1999; 12(2): 58-65.

Soares AVN, Silva IA. Representações de puérperas sobre o sistema alojamento conjunto: do abandono ao acolhimento. Rev Esc Enferm USP [periódico na Internet]. 2003. [citado 2012 ago. 21]; 37(2):72-80. Disponível em:

http://www.scielo.br/pdf/reeusp/v37n2/09.pdf

Soifer R. Psicologia da gravidez, parto e puerpério. Porto Alegre: Artes Médicas; 1986. Estudo psicológico do puerpério; 63-88.

Souza L, Haddad ML, Nakano AMS, Gomes FA. Terapêutica não-farmacológica para alívio do ingurgitamento mamário durante a lactação: revisão integrativa da literatura. Rev Esc Enferm USP [periódico na Internet]. 2012. [citado 2012 set. 18]; 46 (2): 472-9. Disponível em: http://www.scielo.br/pdf/reeusp/v46n2/a29v46n2.pdf

Souto CMRM, Pessoa SMF, Damasceno MMC, Araújo TL. Tendências das pesquisas de enfermagem em saúde da mulher no período de 2001 a 2005. Texto Contexto Enfer. 2007; 16(4): 7119-26.

Stefanello J. A vivência do cuidado no puerpério: as mulheres construindo-se como mães [Dissertação]. Ribeirão Preto (SP): Escola de Enfermagem de Ribeirão Preto, Universidade de São Paulo; 2005.

Stefanello J, Nakano AMS, Gomes FA. Crenças e tabus relacionados ao cuidado no pós-parto: o significado para um grupo de mulheres. Acta Paul Enferm. 2008; 21(2): 275-81. 
Takushi SAM, Tanaka ACA, Gallo PR, Machado MAMP. Motivação de gestantes para o aleitamento materno. Rev Nutr . 2008; 21(5): 491-502.

Thomson Z, Morais AEP. Problemas das mamas e mamilos: como prevenir e tratar. In: Rego LD, editor. Aleitamento Materno - Um guia para pais e familiares. São Paulo: Atheneu; 2008. p. 89-107.

Todos pela educação [homepage na Internet]. São Paulo; c2010. [atualizado 2011; citado 2012 jul. 19]. Disponível em: http://www.todospelaeducacao.org.br/educacaono-brasil/busca-

comparativa/resultado/resultado/pdf/?id_check_criterio $\% 5 \mathrm{~B} \% 5 \mathrm{D}=34 \&$ id_check_crit erio $\% 5 \mathrm{~B} \% 5 \mathrm{D}=35 \& \mathrm{id}$ check_criterio $\% 5 \mathrm{~B} \% 5 \mathrm{D}=41 \& \mathrm{id}$ check_criterio\%5B $\% 5 \mathrm{D}=81$ \&id_check_criterio $\% 5 \mathrm{~B} \% 5 \mathrm{D}=85 \&$ id_check_criterio $\% 5 \mathrm{~B} \% 5 \mathrm{D}=156 \&$ id_check_crite rio $\% 5 \mathrm{~B} \% 5 \mathrm{D}=157 \&$ id_check_criterio $\% 5 \mathrm{~B} \% 5 \mathrm{D}=138 \&$ id universo $\% 5 \mathrm{~B} \% 5 \mathrm{D}=9094 \&$ $\underline{\text { tipo= }=1 \& \mathrm{pdf}=\mathrm{PDF}}$

Tomeleri KR, Marcon SS. Práticas populares de mães adolescentes no cuidado aos filhos. Acta Paul Enferm [periódico na Internet]. 2009. [citado 2012 ago. 21]; 22(3):272-80. Disponível em: http://www.scielo.br/pdf/ape/v22n3/a06v22n3.pdf

Tyrrell MAR, Cabral IE. A produção científica de enfermagem em saúde da mulher e da criança: panorama brasileiro. Rev Enferm UERJ. 2005; 13(1): 103-11.

Vásquez. ML, Argote O. LA, Bejarano NL, Cárdenas CH, Rodríguez LM. El trayecto de la adolescente en el puerperio: amenazas, peligros y acciones de protección durante la "dieta". Texto Contexto Enferm [periódico na Internet]. 2004. [citado 2012 jul. 28]; 13(3):351-9. Disponível em:

http://www.scielo.br/pdf/tce/v13n3/a03v13n03.pdf

Vaucher ALI, Durman S. Amamentação: Crenças e Mitos. REE [periódico na Internet]. 2005. [citado 2010 mar. 19]; 7(2): 207-14. Disponível em: http://www.fen.ufg.br

Vieira LJ, Oliveira MHP, Lèfevre F. O uso da expressão "mal-de-sete-dias" por mães de crianças que morreram de tétano neonatal em Minas Gerais (1997-2002). Texto Contexto Enferm [periódico da Internet]. 2006. [citado 2012 set. 18]; 15(1): 51-9. Disponível em: http://www.scielo.br/pdf/tce/v15n1/a06v15n1.pdf

Vieira F, Bachlon MM, Salge AKM, Munari DB. Diagnóstico de enfermagem da NANDA no pós-parto imediato e tardio. Esc Anna Nery Rev Enferm [periódico na Internet]. 2010. [citado 2012 ago. 08]; 14(1): 83-9. Disponível em: http://www.scielo.br/pdf/ean/v13n1/v13n1a16.pdf 
Waugh LJ. Beliefs associated with Mexican immigrant families' practice of la cuarentena during postpartum recovery. J Obstet Gynecol Neonatal Nurs. [serial on the Internet]. 2011. [cited 2012 aug. 4]; 40(6):732-41. Available from: http://onlinelibrary.wiley.com/doi/10.1111/j.1552-6909.2011.01298.x/pdf

Weiszflog W, editor. Michaelis - Moderno dicionário da língua portuguesa. São Paulo: Melhoramentos; 2007.

Werner D. Onde não há médico. Nacional: Paulus; 1994. 440 p.

Wiegers TA. Adjusting to motherhood Maternity care assistance during the postpartum period: How to help new mothers cope. Journal of Neonatal Nursing [serial on the Internet]. 2006. [cited 2012 aug. 3]; 12(5): 163-71. Available from: http://nv1002.nivel.nl/postprint/PPpp2658.pdf

Zagonel IPS, Martins M, Pereira KF, Athayde J. O cuidado humano diante da transição ao papel materno: vivências no puerpério. REE [periódico na Internet]. 2003. [citado 2012 ago. 12]; 5(2):24-32. Disponível em: http://www.fen.ufg.br/fen_revista/revista5_2/pdf/materno.pdf

Zorzi NT, Bonilha ALL. Práticas utilizadas pelas puérperas nos problemas mamários. Rev Bras Enferm [periódico na Internet]. 2006. [citado 2012 ago. 16]; 59(4): 521-6. Disponível em: http://www.scielo.br/pdf/reben/v59n4/a09v59n4.pdf 


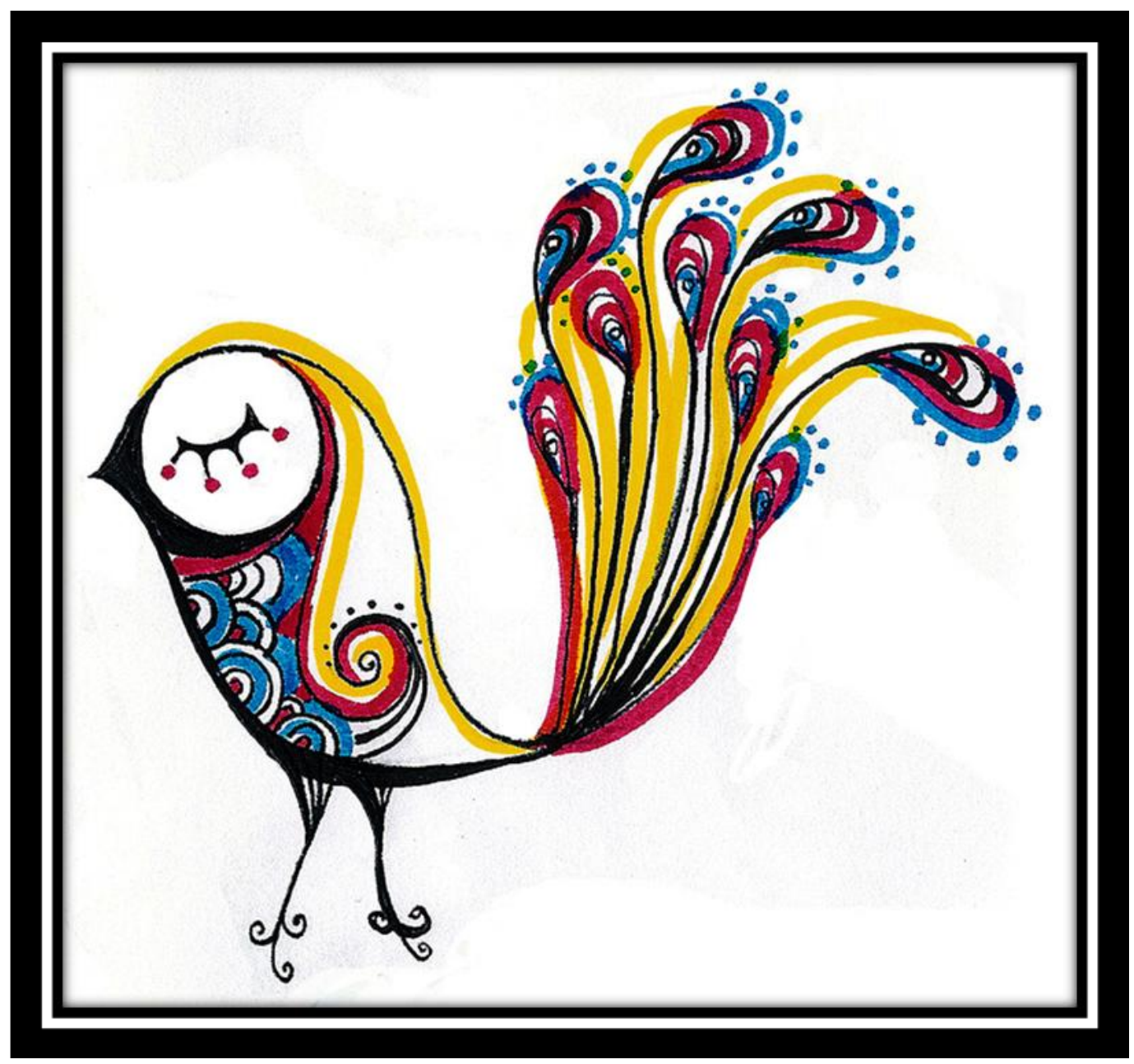

Fonte: http://paulicasantos.wordpress.com/

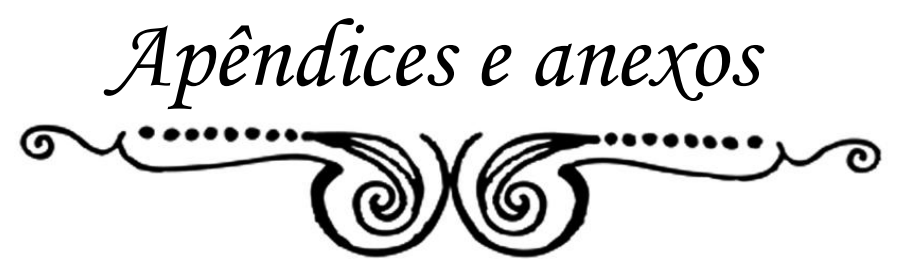




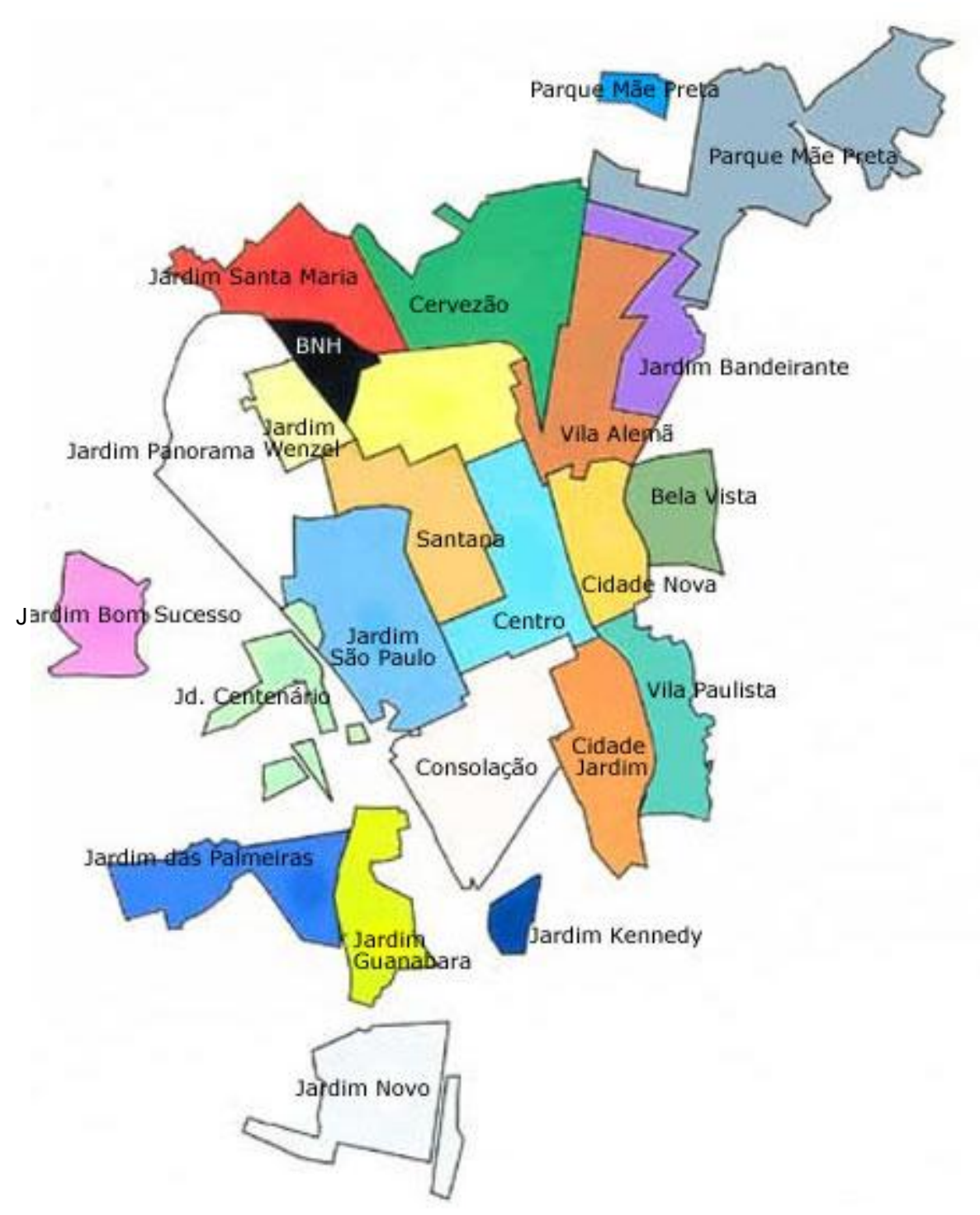

Mapa parcial dos bairros de Rio Claro, São Paulo.

Fonte: http://www.visiterioclaro.com.br/interna.php?idm=10\&coract=1\&matt=743

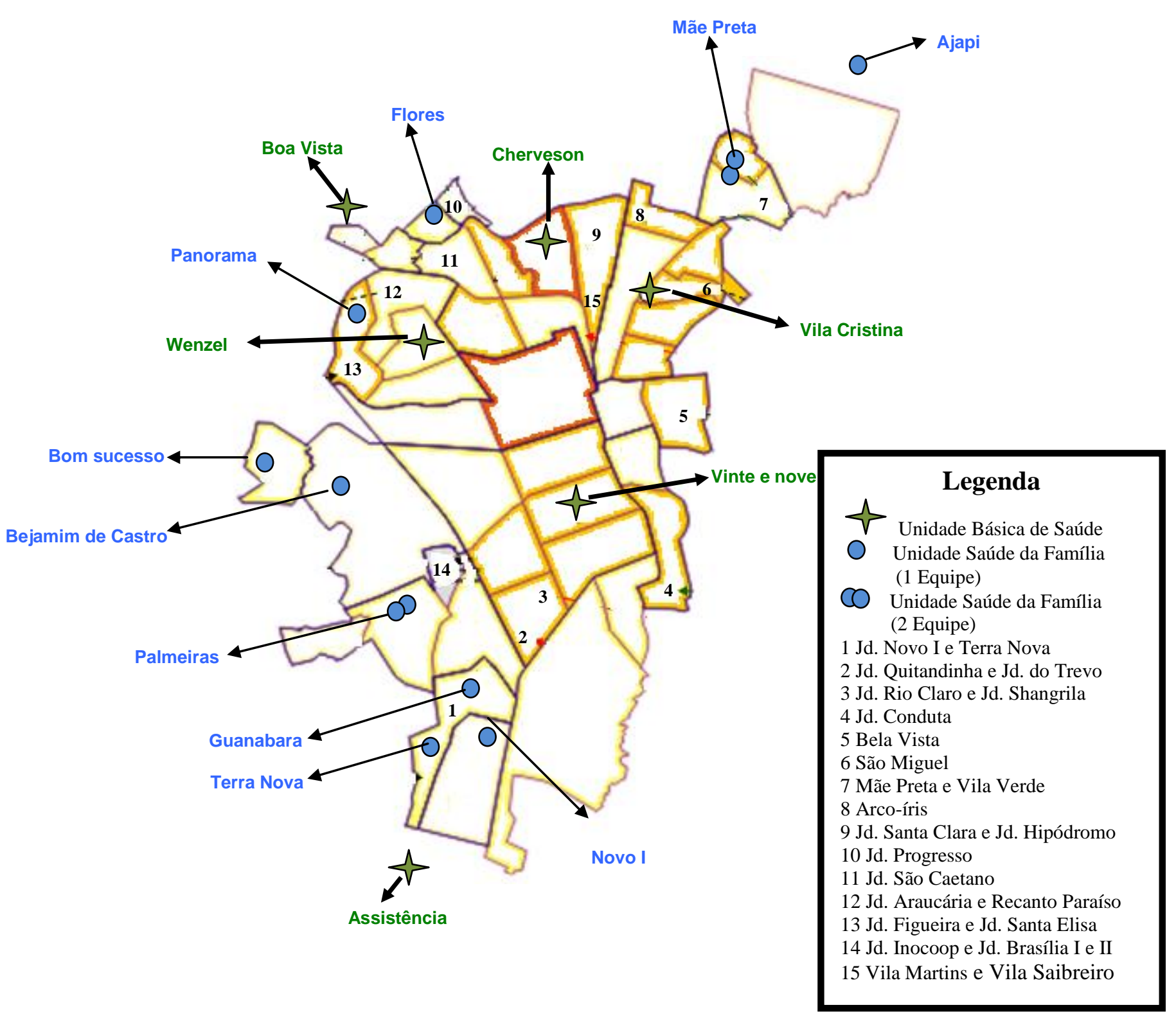

Mapa das Unidades de Saúde e regiões setoriais do munícipio de Rio Claro, São Paulo. Fonte: Fundação Municipal de Saúde de Rio Claro 


\section{APÊNDICE B}

Ao

Secretário Municipal de Saúde de Rio Claro

Prezado Senhor,

Eu, Nayara Girardi Baraldi, obstetriz, aluna do curso de Mestrado da Escola de Enfermagem da Universidade de São Paulo, estou realizando a pesquisa "Período pós-parto: Práticas de escolha para o autocuidado da mulher", que tem como objetivo geral: Conhecer as práticas de autocuidado da mulher durante o período pós-parto. O estudo será realizado com mulheres, que freqüentam uma Unidade Básica de Saúde deste município. Este trabalho é orientado pela Profa. Dra. Neide de Souza Praça, docente do citado Programa de Pós-Graduação.

Pedimos por meio deste ofício a liberação do campo de pesquisa: Unidade Básica de Saúde “Oreste Armando Giovanni" - "UBS da 29". Informo que os dados serão coletados na referida unidade por meio de uma entrevista que será agendada com a mulher após sua consulta de retorno puerperal realizada na mesma.

Caso a puérpera não aceite participar do estudo, será garantido que não sofrerá qualquer prejuízo por esta decisão.

Salientamos que não será gerado nenhum ônus financeiro para a instituição, ou para a mulher.

Em APÊNDICE encaminhamos aprovação do Comitê de Ética em Pesquisa, assim como cópia do Projeto de Pesquisa para sua avaliação.

Agradecendo sua atenção, colocamo-nos à disposição para esclarecimento de possíveis dúvidas. No aguardo de seu parecer

Atenciosamente,

São Paulo, 19 / $105 / 2011$

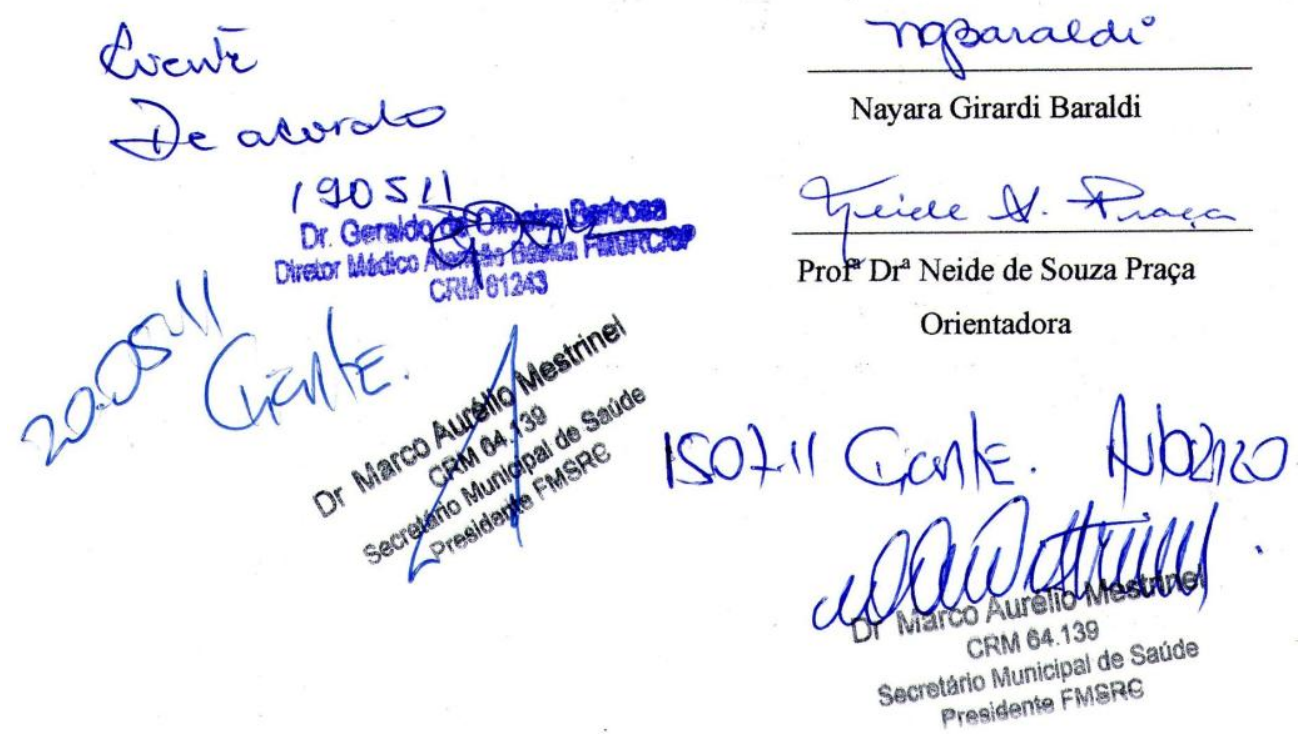




\section{APÊNDICE C}

\section{CARTA DE APRESENTAÇÃO}

\section{Título do projeto:}

"Período pós-parto: Práticas de escolha para o autocuidado da mulher"*

\section{Principais finalidades:}

- Divulgar a importância do período após o nascimento do bebê.

- Conhecer as práticas de cuidado da mulher-mãe, após o nascimento do bebê.

- Contribuir para a melhoria da assistência a mulher junto ao serviço de saúde materno-infantil.

\section{Etapas da entrevista:}

Primeiro momento: Acolhimento no posto de saúde.

Segundo momento: Entrevista entre $30^{\circ}$ e $45^{\circ}$ dias após o nascimento do bebê, composta pelo preenchimento de um formulário do perfil da mulher-mãe, em seguida, entrevista gravada junto com a pesquisadora contando quais são seus cuidados com você, após o nascimento do bebê.

Dados coletados: Serão analisados e, dará origem a dissertação de mestrado ("livro"), com os relatos das mulheres-mães, mantendo seus nomes em sigilo, durante todo o processo. Essas dissertações ficaram expostas, provavelmente, na Escola de Enfermagem da Universidade de São Paulo-USP, na Fundação Municipal de Saúde e, todas que participaram para a formulação da pesquisa receberam seus relatos e a contribuição de cada mulher-mãe na elaboração desse estudo.

\section{Demais dados:}

- Não gerará gastos para as mulheres-mães entrevistadas.

- O pesquisador e a mulher terão contatos pessoais e via telefone.

\section{Contato da Pesquisadora:}

Nayara Girardi Baraldi (Obstetriz)

Telefones: 3533-XXXX ou 9666-XXXX

\footnotetext{
* Mantido título e texto original apresentado à puérpera.
} 
APÊNDICE D

FICHA DE IDENTIFICAÇÃO DA PUÉRPERA

NOME:

APELIDO:

$\mathrm{N}^{\circ}$ DO PRONTUÁRIO:

DATA DO PARTO:

DATA DO ACOLHIMENTO:

ENDEREÇO:

TELEFONE RESIDENCIAL:

TELEFONE CELULAR:

TELEFONE RESIDENCIAL PARA RECADO:

PARENTESCO:

TELEFONE CELULAR PARA RECADO:

PARENTESCO:

DATA DA PRÓXIMA CONSULTA:

PREFERÊNCIA DO LOCAL DA ENTREVISTA:

( )CASA ( )POSTO DE SAÚDE-UBS

OBSERVAÇÃO DA PESQUISADORA: 


\section{APÊNDICE E}

\section{TERMO DE CONSENTIMENTO LIVRE E ESCLARECIDO}

Eu, Nayara Girardi Baraldi, obstetriz, aluna do curso de mestrado da Escola de Enfermagem da Universidade de São Paulo, estou realizando a pesquisa "Período pós-parto: Práticas de escolha para o autocuidado da mulher", para saber onde e com quem as mulheres que freqüentam esta UBS aprendem a cuidar de si após o parto. Este trabalho é orientado pela Profa. Dra. Neide de Souza Praça.

Necessito que responda uma entrevista, que será gravada, durando aproximadamente 40 minutos, e realizada em local e horário de sua escolha. A senhora é livre para não querer participar do estudo, e para desistir do mesmo a qualquer momento, sem que seu atendimento, ou de sua família, na UBS, seja prejudicado. A senhora não terá nenhum gasto, e seu nome não será divulgado. Os resultados serão divulgados em eventos e publicados em revistas científicas mantendo. O que a senhora disser será do conhecimento meu e de minha orientadora, mantendo o sigilo de sua participação.

Este documento tem duas vias, e após nossa assinatura, a senhora ficará com uma via e eu com a outra. Em caso de dúvidas a senhora poderá entrar em contato comigo pelo telefone (19) 9666-XXXX, ou contatar o Comitê de Ética em Pesquisa da Escola de Enfermagem da Universidade de São Paulo, no e-mail: edipesq@usp.br.

Declaro que li e compreendi as informações recebidas. Fui esclarecida sobre todas as dúvidas apresentadas e aceito as condições acima descritas.

Local e data:

Nome:

Assinatura da entrevistada

Assinatura da pesquisadora 


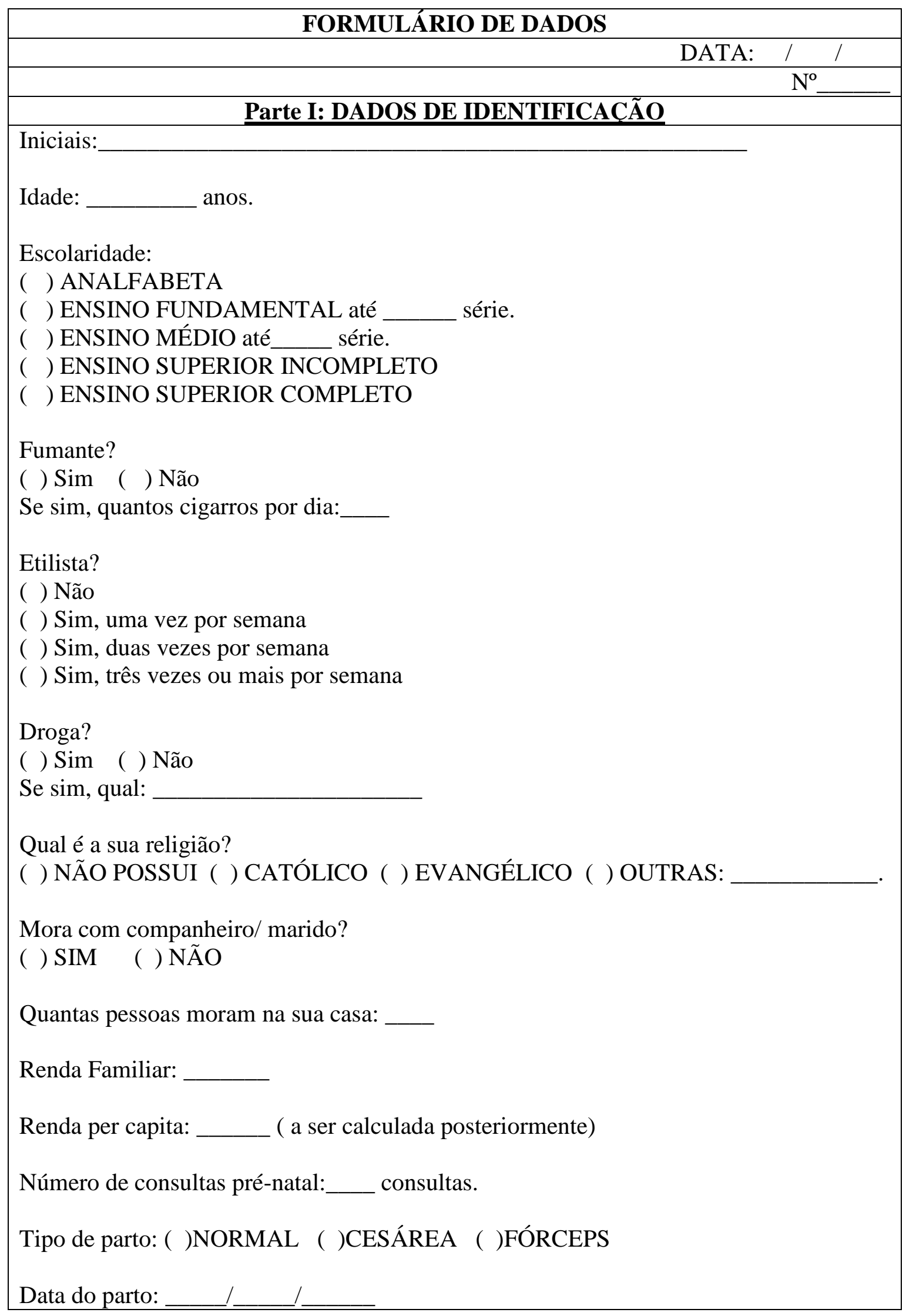


Como você vinha para o posto de saúde fazer pré-natal?

( ) De carro particular

( ) A pé

( ) Ônibus

( ) Táxi

( ) Outro meio de transporte. Qual:

Como veio para o posto de saúde fazer as consultas após o nascimento do bebê?

( ) De carro particular

( ) A pé

( ) Ônibus

( ) Táxi

( ) Outro meio de transporte. Qual:

Você conviveu com quais familiares?

( ) BISAVÓS MATERNOS ( $2^{\circ}$ grau de parentesco depois dos avós)

( ) BISAVÓS PATERNOS ( $2^{\circ}$ grau de parentesco depois dos avós)

( ) AVÓS MATERNOS ( $1^{\circ}$ grau de parentesco após os pais)

( ) AVÓS PATERNOS ( $1^{\circ}$ grau de parentesco após os pais)

( ) MÃE

( ) PAI

( ) SOGRA

( ) SOGRO

( ) IRMÃO (A)

( ) OUTROS, quais?

Você convive com algum desses familiares?

( ) BISAVÓS MATERNOS ( $2^{\circ}$ grau de parentesco depois dos avós)

( ) BISAVÓS PATERNOS ( $2^{\circ}$ grau de parentesco depois dos avós)

( ) AVÓS MATERNOS ( $1^{\circ}$ grau de parentesco após os pais)

( ) AVÓS PATERNOS ( $1^{\circ}$ grau de parentesco após os pais)

( ) MÃE

( ) PAI

( ) SOGRA

( ) SOGRO

( ) IRMÃO (A)

( ) OUTROS, quais?

( ) NENHUM

\section{Parte II - DADOS SOBRE O PÓS-PARTO}

Como você chama o período após o nascimento do bebê?

( ) PÓS-PARTO ( ) PUERPÉRIO ( ) RESGUARDO （）DIETA ( ) OUTRAS,

Quando teve alguma dúvida sobre cuidados depois do nascimento do bebê, recebeu ajuda de alguém?

( ) SIM ( ) NÃO ( ) NÃO TIVE DÚVIDAS 
Se sim, quem:

Alguém te ensinou sobre como cuidar de sua higiene depois do nascimento do bebê?

( ) SIM ( ) NÃO

Se sim, quem:

Alguém te ensinou sobre como cuidar de sua alimentação depois do nascimento do bebê?

( ) SIM ( ) NÃO

Se sim, quem:

Alguém te falou sobre repouso depois do nascimento do bebê?

( ) SIM ( ) NÃO

Se sim, quem:

Alguém te falou sobre como se vestir depois do nascimento do bebê?

( ) SIM ( ) NÃO

Se sim, quem:

Como você ficou sabendo sobre cuidar da sua higiene depois do nascimento do bebê?

( )Por orientação de familiares

( )Por orientação de amigos

( )Por orientação na maternidade

( )Por orientação na UBS, no "postinho"

( ) $\mathrm{Na} \mathrm{TV}$

( )No rádio

( )Em folhetos

( ) Em livros

( )Em revistas

( ) Na internet - ( ) Por redes sociais / ( ) Por blogs / Por sites

Como você ficou sabendo sobre cuidar da sua alimentação depois do nascimento do bebê?

( )Por orientação de familiares

( )Por orientação de amigos

( )Por orientação na maternidade

( )Por orientação na UBS, no "postinho"

( ) Na TV

( )No rádio

( )Em folhetos

( )Em livros

( ) Em revistas

( ) Na internet - ( ) Por redes sociais / ( ) Por blogs / Por sites

Como você ficou sabendo sobre cuidar de seu repouso depois do nascimento do bebê?

( )Por orientação de familiares

( )Por orientação de amigos

( )Por orientação na maternidade

( )Por orientação na UBS, no "postinho"

( ) Na TV

( )No rádio

( )Em folhetos 


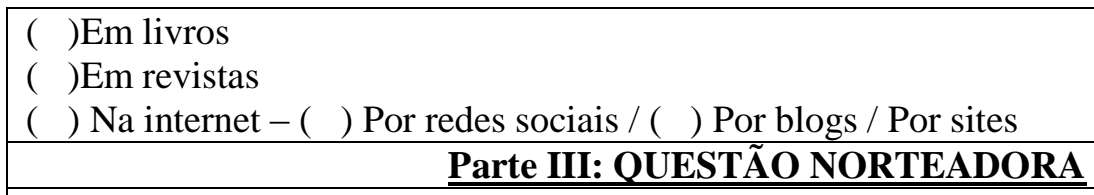

Me fale os cuidados que você está tendo com você após o nascimento do bebê.

TEMAS COMPLEMENTARES

1. Higiene

2. Alimentação

3. Repouso 


\section{ANEXO G}

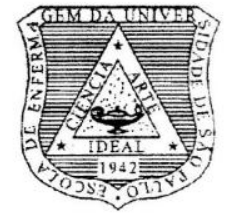

\section{UNIVERSIDADE DE SÃO PAULO \\ ESCOLA DE ENFERMAGEM}

Av. Dr. Enéas de Carvalho Aguiar, 419 - CEP 05403-000

Tel.: (011) 3061-7548/8858 - Fax: (011) 3061-7548 -

São Paulo - SP - Brasil

e-mail: edipesq@usp.br

São Paulo, 17 de dezembro de 2010.

$\mathrm{Ilm}^{\mathrm{a}} \mathrm{Sr}^{\mathrm{a}}$

Prof. ${ }^{\mathrm{a}}$ Dr. ${ }^{\mathrm{a}}$ Neide de Souza Praça

Ref: Processo $n^{\circ}$ 989/2010/CEP-EEUSP

Prezada Senhora,

Em atenção à solicitação referente à análise do projeto "Cuidados no pósparto: adesão às crenças de transmissão intergeracional", informamos que o mesmo foi considerado aprovado pelo Comitê de Ética em Pesquisa da Escola de Enfermagem da Universidade de São Paulo (CEP/EEUSP).

Analisado sob o aspecto ético-legal, atende às exigências da Resolução $n^{\circ}$ 196/96 do Conselho Nacional de Saúde.

Esclarecemos que após o término da pesquisa, os resultados obtidos deverão ser encaminhados ao CEP/EEUSP, para serem anexados ao processo.

Atenciosamente,

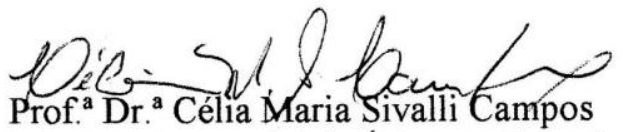

Coordenadora do Comitê de Ética em Pesquisa da

Escola de Enfermagem da Universidade de São Paulo 


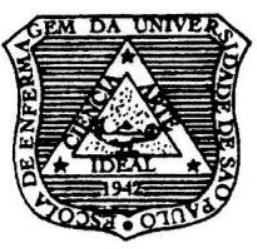

\section{UNIVERSIDADE DE SÃO PAULO \\ ESCOLA DE ENFERMAGEM}

Av. Dr. Enéas de Carvalho Aguiar, 419 - CEP 05403-000

- Fone.: 3066-7548 - Fax.: 280-8213

C.P. 41633 - CEP $05422-970$ - e-mail.: ee@edu.usp.br

São Paulo, 10 de março de 2011.

$\mathrm{Ilm} .{ }^{\mathrm{a}} \mathrm{Sr}{ }^{\mathrm{a}}$.

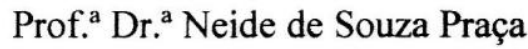

Ref: Processo $n^{\circ}$ 989/2010/CEP-EEUSP

Prezada Senhora,

Conforme solicitação de V.S. ${ }^{a}$ informamos que o Comitê de Ética em Pesquisa da Escola de Enfermagem da Universidade de São Paulo, aprovou a alteração do título do projeto: "Cuidados no pós-parto: adesão às crenças de transmissão intergeracional" para "Período pós-parto: práticas de escolha para o autocuidado da mulher", da aluna Nayara Girardi Baraldi, sob sua orientação, considerando que não há óbices éticos com essa alteração.

Atenciosamente,

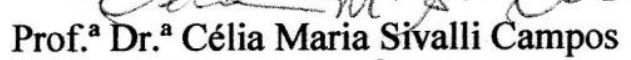

Coordenadora do Comitê de Ética em Pesquisa da Escola de Enfermagem da Universidade de São Paulo 
APÊNDICE H

\begin{tabular}{|c|c|c|c|c|c|c|c|c|c|c|c|c|c|c|c|}
\hline \multirow[t]{2}{*}{ DEUSA } & \multirow[t]{2}{*}{ IDADE } & \multirow[t]{2}{*}{ ESCOLARIDADE } & \multirow[t]{2}{*}{ RELIGIÃo } & \multirow[t]{2}{*}{ DROGADIÇÃO } & \multirow[t]{2}{*}{ TABAGISMO } & \multirow[t]{2}{*}{ ETILISMO } & \multirow[t]{2}{*}{$\begin{array}{c}\text { RENDA } \\
\text { (SM) }\end{array}$} & \multirow{2}{*}{$\begin{array}{c}\text { RENDA } \\
\text { PER } \\
\text { CAPITA }\end{array}$} & \multirow{2}{*}{$\begin{array}{c}\mathbf{N}^{\circ} \text { DE } \\
\text { RESIDENTES } \\
\text { EM MESMO } \\
\text { DOMÍ́CILIO }\end{array}$} & \multirow[t]{2}{*}{$\begin{array}{c}\mathbf{N}^{\circ} \\
\text { CONSULTAS } \\
\text { PRÉ-NATAL }\end{array}$} & \multicolumn{2}{|c|}{$\begin{array}{c}\text { MEIOS DE } \\
\text { TRANSPORTE }\end{array}$} & \multirow{3}{*}{$\begin{array}{c}\text { TIPO } \\
\text { DE } \\
\text { PARTO } \\
\text { PC }\end{array}$} & \multirow{3}{*}{$\begin{array}{c}\text { DIAS } \\
\text { DE } \\
\text { PÓS- } \\
\text { PARTO } \\
37 \\
\end{array}$} & \multirow{3}{*}{$\begin{array}{c}\text { NOME } \\
\text { ATRIBUÍDO } \\
\text { AO } \\
\text { PERÍODO } \\
\text { PÓS-PARTO } \\
\text { Resguardo }\end{array}$} \\
\hline & & & & & & & & & & & $\mathbf{P N}_{1}$ & $\mathbf{P P}$ & & & \\
\hline Afrodite & 18 & $1^{\circ}$ ano EM & Evangélica & $\begin{array}{l}----- \\
-1\end{array}$ & ----- & ----- & $1-2$ & 200 & 5 & 7 & A pé & A pé & & & \\
\hline Deméter & 28 & $3^{\circ}$ ano EM & Espírita & ----- & Sim & $-\overline{----}$ & $1-2$ & 750 & 4 & 13 & Moto & Moto & $\mathrm{PC}$ & 44 & $\begin{array}{c}\text { Dieta e } \\
\text { Aprendizado }\end{array}$ \\
\hline Ártemis & 18 & $3^{\circ}$ ano EM & $\begin{array}{c}\text { Evangélica } \\
\text { (não } \\
\text { praticante) }\end{array}$ & ----- & ----- & ----- & $5-6$ & 600 & 5 & 10 & Carro & Carro & $\mathrm{PN}$ & 42 & Resguardo \\
\hline Héstia & 27 & ES completo & Católica & $-\ldots---$ & $-\ldots---$ & ------ & $4-5$ & 766 & 3 & 10 & Carro & Carro & $\mathrm{PC}$ & 42 & Dieta \\
\hline Perséfone & 20 & $1^{\circ}$ ano EM & 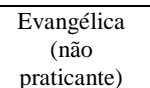 & ------ & ----- & ----- & $5-6$ & 500 & 6 & 6 & A pé & A pé & $\mathrm{PC}$ & 34 & Dieta \\
\hline Hera & 21 & $3^{\circ}$ ano EM & Evangélica & ---- & ---- & ---- & $5-6$ & 428 & 7 & 7 & Carro & Carro & $\mathrm{PC}$ & 44 & $\begin{array}{l}\text { Momento de } \\
\text { tranqüilidade }\end{array}$ \\
\hline Gaia & 22 & $3^{\circ}$ ano EM & Católica & 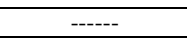 & ----- & ----- & $2-3$ & 375 & 4 & 9 & Moto & Moto & $\mathrm{PN}$ & 42 & Dieta \\
\hline Nice & 18 & $3^{\circ}$ ano EM & Católica & ---- & ---- & ---- & $4-5$ & 440 & 6 & 10 & Bicicleta & A pé & $\mathrm{PC}$ & 39 & $\begin{array}{c}\text { Dieta e } \\
\text { quarentena }\end{array}$ \\
\hline Atena & 22 & ES incompleto & Agnóstica & $\begin{array}{c}\text { Maconha } \\
\text { (Experiência } \\
\text { anterior à } \\
\text { gestaçãao) }\end{array}$ & $\begin{array}{l}---- \\
-\end{array}$ & $\begin{array}{l}----- \\
\end{array}$ & $7-8$ & 666 & 6 & 7 & A pé & Carro & $\mathrm{PC}$ & 41 & Pós-parto \\
\hline Hebe & 20 & $3^{\circ}$ ano EM & Católica & $-y_{3}$ & ----- & ----- & $4-5$ & 540 & 6 & 10 & Carro & Carro & $\mathrm{PC}$ & 41 & Dieta \\
\hline Ariadne & 24 & $3^{\circ}$ ano EM & Católica & ------ & ----- & ----- & $\begin{array}{c}\text { Não } \\
\text { soube } \\
\text { informar }\end{array}$ & $\begin{array}{c}\text { Não } \\
\text { soube } \\
\text { informar }\end{array}$ & 3 & 10 & A pé & A pé & $\mathrm{PN}$ & 41 & Dieta \\
\hline Selene & 18 & $3^{\circ}$ ano EM & $\begin{array}{l}\text { Testemunha } \\
\text { de Jeová }\end{array}$ & ----- & ----- & ----- & $\begin{array}{c}\text { Não } \\
\text { soube } \\
\text { informar }\end{array}$ & $\begin{array}{c}\text { Não } \\
\text { soube } \\
\text { informar }\end{array}$ & 7 & 5 & Carro & Carro & $\mathrm{PN}$ & 36 & $\begin{array}{l}\text { Dieta e } \\
\text { resguardo }\end{array}$ \\
\hline Eva & 30 & $3^{\circ}$ ano EM & Católica & ----- & ------ & ----- & $2-3$ & 400 & 4 & 8 & Carro & Ônibus & $\mathrm{PN}$ & 45 & Resguardo \\
\hline Têmis & 32 & $3^{\circ}$ ano EM & Católica & $-\overline{----}$ & ----- & ----- & $2-3$ & 433 & 3 & 12 & Carona & Carona & PC & 39 & $\begin{array}{c}\text { Dieta e } \\
\text { resguardo }\end{array}$ \\
\hline Nêmesis & 18 & $3^{\circ}$ ano EM & $\begin{array}{l}\text { Católica } \\
\end{array}$ & ----- & ----- & ----- & $3-4$ & 400 & 5 & 12 & A pé & Carro & $\mathrm{PC}$ & 43 & Dieta \\
\hline Eirene & 19 & $3^{\circ}$ ano EM & Evangélica & ----- & ----- & ----- & $3-4$ & 600 & 3 & 11 & Ônibus & Ônibus & PC & 38 & Resguardo \\
\hline Íris & 21 & $3^{\circ}$ ano EM & Agnóstica & $-\ldots-\ldots$ & $-\ldots---{ }_{-1}$ & ----- & $3-4$ & 333 & 6 & 9 & Carro & Carro & $\mathrm{PC}$ & 42 & Dieta \\
\hline Anfitrite & 21 & $3^{\circ}$ ano EM & Evangélica & Cocaína & ----- & Sim & $1-2$ & 145 & 6 & 3 & Moto & Moto & $\mathrm{PC}$ & 42 & Resguardo \\
\hline Sophia & 23 & $2^{\circ}$ ano EM & Católica & $-\cdots$ & ----- & ----- & $4-5$ & 383 & 6 & 9 & Carro & Carro & $\mathrm{PN}$ & 38 & Dieta \\
\hline Pandora & 20 & $3^{\circ}$ ano EM & $\begin{array}{l}\text { Testemunha } \\
\text { de Jeová }\end{array}$ & ----- & ---- & ----- & $1-2$ & 266 & 3 & 11 & A pé & A pé & $\mathrm{PC}$ & 31 & Pós-parto \\
\hline
\end{tabular}

